Szegedi Tudományegyetem

Bölcsészet- és Társadalomtudományi Kar

\author{
DOKTORI DISSZERTÁCIÓ
}

Herczegh Máté

\title{
A KITERJEDT ELME HIPOTÉZIS ÉS LEHETSÉGES ELÁGAZÁSAI
}

Málnási Bartók György Filozófia Doktori Iskola

Metafizika és metafizikakritika alprogram

Témavezető:

Dr. habil. Mogyoródi Emese

egyetemi docens

SZTE, Filozófia Tanszék

Szeged

2019. 


\section{NYILATKOZAT}

Alulírott Herczegh Máté a Szegedi Tudományegyetem Bölcsészettudományi Karának hallgatója ezennel büntetőjogi felelősségem tudatában nyilatkozom és aláírásommal igazolom, hogy

\section{A kiterjedt elme hipotézis és lehetséges elágazásai}

címü doktori disszertációm saját, önálló munkám; az abban hivatkozott nyomtatott és elektronikus szakirodalom felhasználása a szerzői jogok nemzetközi szabályainak megfelelően készült.

Tudomásul veszem, hogy doktori disszertáció esetén plágiumnak számít:

• szószerinti idézet közlése idézőjel és hivatkozás megjelölése nélkül;

- tartalmi idézet hivatkozás megjelölése nélkül;

• más publikált gondolatainak saját gondolatként való feltüntetése.

Alulírott kijelentem, hogy a plágium fogalmát megismertem, és tudomásul veszem, hogy plágium esetén szakdolgozatom visszautasításra kerül.

Szeged, év hó nap 


\section{Köszönetnyilvánítás}

Hálámat szeretném kifejezni:

Nagy Sándornak és Filep Cecíliának, akik töretlen morális támogatása nélkül ez a dolgozat nem készülhetett volna el.

Édesanyámnak, édesapámnak és testvéremnek, akik anyagi támogatásukkal életben tartottak a dolgozat írása alatt (is).

Dr. Mogyoródi Emesének és Dr. Simon Józsefnek, akik révén a dolgozat elnyerte végső formáját.

Dr. Kalács Jenőnek az inspirációért. 


\section{A kiterjedt elme hipotézis és lehetséges elágazásai}

\section{Tartalom}

1. Bevezetés - a bacillus subtilis esete. .1

2. Előzmények, kontextus .3

2.1. A cogitotól a modulokig . .3

2.2. Az elme modularitása . .6

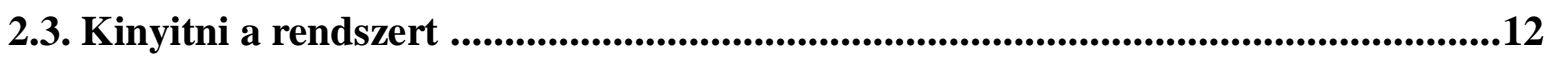

2.3.1. Test az elmében (embodied mind) ....................................................................13

2.3.2. Világ az elmében (embedded mind) .............................................................14

3. A kiterjedt elme ..................................................................................................17

3.1. Az eredeti gondolatmenet.............................................................................................17

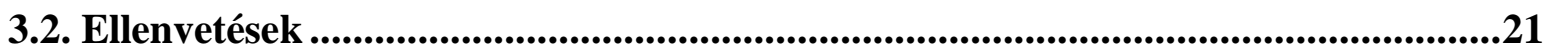

3.2.1. Konstitúció: de mié? ..................................................................................21

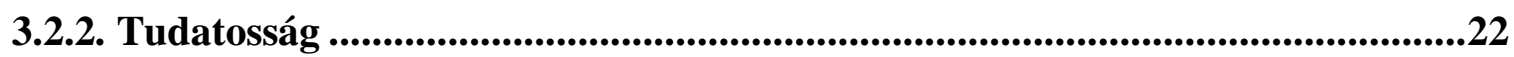

3.2.3. A paritás elve és a különbözőségi ellenérvek .............................................24

3.2.4. Egy vagy két lépéses rendszer .......................................................................25

3.2.5. Különbségek, másként .............................................................................30

3.2.6. Természetes, pszichológiai és tudományos fajták............................................36

3.2.7. A ,kapcsolat-konstitúciós hiba" hiba......................................................40

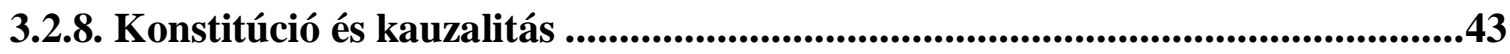

3.2.9. A kogníció megkülönböztető jegye ....................................................................46

3.2.10. Kontroll helye ellenvetés...............................................................................48

3.2.11. Testi szituáltság és funkcionalizmus........................................................49

3.2.11.1. Érzékszervi helyettesítés..........................................................................55

3.2.12. Kognitív felfúvódás, csúszós lejtő és a határtalan elme ................................57

3.2.13. A cselekvések proliferációja ......................................................................64

3.2.14. Elfogadhatatlan én-kép - A dividuum .........................................................67

3.3. A dilemma: túl kicsi és túl nagy elmék ..............................................................72

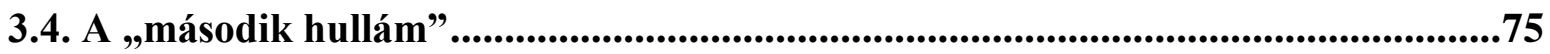

3.4.1. A kiterjedt fenotípus és az emberi transzformer .........................................75

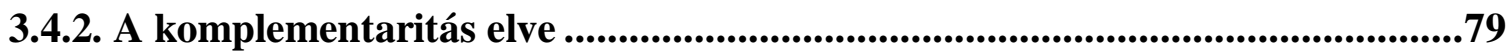

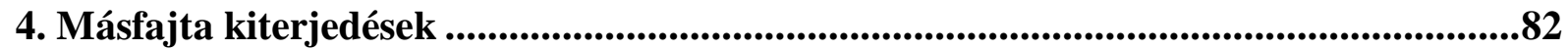

4.1. Javaslat egy módosításra............................................................................82

4.2. A társas kiterjedés..........................................................................................866

4.2.1. Szuperorganizmikus tendenciák és pszichológiai malter...............................90 
4.2.2. A társas kiterjedt elme gerince .................................................................102

4.2.3. Egy kontinentális példa - Heidegger......................................................105

4.3. A transzformatív kiterjedés - Kultúra és elme ....................................................108

4.3.1. Az elme kint hordott része .......................................................................119

5. A globális elme felé ...................................................................................................................133

5.1. Kognitív intézmények.....................................................................................................134

5.2. Az intencionális alapállás nézőpontja .............................................................143

6. A kognitív kiterjedések taxonómiája ...............................................................................147

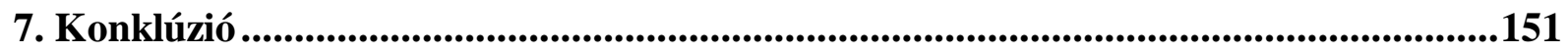

Felhasznált irodalom ................................................................................................153 


\section{Bevezetés - a bacillus subtilis esete}

A jelen dolgozat tárgya a kiterjedt elme hipotézis, és a hipotézis kapcsán felvetődő legfőbb elmefilozófiai problémák megvitatása, abból a célból, hogy - bizonyos módosításokkal - bemutassam védhetőségét és további lehetséges teoretikus irányait vázoljam fel. Andy Clark és David Chalmers mára klasszikussá vált, „The Extended Mind”1 címü tanulmánya az egyik leghevesebb kortárs elmefilozófiai vita gyújtópontja, mely meglehetősen széles érzelmi és intellektuális spektrumon vert és ver visszhangot. Ez érthető, hiszen feltevésüknek erős metafizikai pikantériája (is) van. Azt állítják, hogy mentális folyamatokat nem kizárólag agyi folyamatok realizálhatnak, hanem például a külvilág megfelelően használt elemei is, mint amilyen egy notesz vagy okostelefon. Vagyis bizonyos feltételek teljesülése esetén az elme „kilóg” a fejből, kiterjed a testen túlra. Hogy ez a prima facie értelmetlennek tünő kijelentés értelmet nyerjen, és az olvasó érthető okokból háborgó intuitív indulatai megnyugodjanak, érdemes mielőbb felidézni egy példát. A bacillus subtilis ${ }^{2}$ sejtmembránja révén elkülönül környezetétől, akár a pók is az általa szőtt hálójától. Csakhogy fehérjebontó enzimeket bocsát ki magából, amelyek a közelben található fehérjéket aminosavakra bontják, melyeket azután be tud építeni magába. Alaktanilag a bacillus subtilishez nem tartoznak hozzá ezek a körülötte lévő enzimek, de ha a funkcionalitás felől vizsgálódunk, akkor nagyon is. A szerzők ilyen értelemben, a funkcionalizmus talaján állva állítják, hogy az elme kiterjedhet a testen túlra, és erre építkezve próbálják meg az emberi kogníció kiterjedésének teoretikus lehetőségét megalapozni.

A dolgozat gondolati íve a következőképp épül fel. A gondolatmenet első részében igyekszem felmutatni, hogy a mainstream kognitív tudományban és az ahhoz kapcsolódó filozófiai elméletalkotásban miként maradt fenn Descartes szelleme, mely a kogníciót izoláltan, egyfajta módszertani szolipszizmusban vizsgálja. Ez leginkább Jerry Fodor moduljaiban csúcsosodik ki. Az elmélettel kapcsolatban elöször röviden arra mutatok rá, hogy az még az elmén belüli alkalmazásában sem feltétlenül meggyőző, ezért érdemes a kognitív rendszert a környezete szempontjából is megvizsgálni, és áttekinteni a kiterjedt elmével rokon egyéb szituált elméleteket, illetve az őket motiváló tudományos eredményeket is.

A dolgozat második fó része Clark és Chalmers eredeti gondolatmenetét tárgyalja, és megkísérel választ adni az elmélettel szemben felhozott legjelentősebb ellenvetésekre, illetve

\footnotetext{
${ }^{1}$ Clark és Chalmers (1998).

${ }^{2}$ A példát Csányi (2018)-tól kölcsönöztem.
} 
felvázolni a megoldási kísérletek lehetséges irányait. Akár elfogadjuk végkövetkeztetéseit, akár nem, Clark és Chalmers tanulmányának elvitathatatlan érdeme, hogy a mentálisról alkotott fogalmunk revíziójára késztet, amennyiben a következő dilemma elé állít minket: az elmét kénytelenek vagyunk vagy túl szüken felfogni, vagy pedig túl tágan. És bár prima facie az előbbi tűnik kevésbé kontraintuitívnak (főleg, hogy a kiterjedt elme elfogadásával olyan csúszós lejtőre lépünk, hogy az elme szinte a végtelenségig „felfúvódhat”), mégis úgy tűnik, hogy amennyiben jobban szemügyre vesszük, a kiterjedt elme a kevésbé problémás alternatíva.

Az elmélet bizonyos hiányosságai azonban szükségessé teszik, hogy változtassunk azon kritériumok listáján, melyek alapján a szerzőpáros bizonyos internális és externális elemekből is álló hibrid rendszereket kognitívként gondol el. A változtatás mögötti motiváció kettős: egyrészt meglátásom szerint következik az eredeti gondolatmenetből is (történetesen a paritási elv szellemiségéből), másrészt vannak olyan szociálpszichológiai jelenségek, társas helyzetek, amelyek remekül illeszkednek a kiterjedt elme (némiképp megváltoztatott) keretébe. Ezt a fajta kognitív összekapcsolódást társas kiterjedt elmének nevezem. A szakirodalomban utalásszinten lehet találkozni ilyen rendszerekkel, de (legjobb tudomásom szerint) nem kerülnek explikálásra. Ugyanez a helyzet egy harmadik fajta kognitív összekapcsolódással is, melyet a kiterjedt elme „harmadik hullámának” is szokás nevezni, mely az externális elemek transzformatív hatását hangsúlyozza. A dolgozat második része tehát a kogníció e három összekapcsolódását szálazza szét és elemzi.

A harmadik rész a kiterjedt elme elméletének maximális végiggondolására vállalkozik, és felveti a globális elme konceptuális lehetőségét, mely azonban - némiképp meglepő módon - nem reductio ad absurdum érvként szolgál a kiterjedt elme hipotézisével szemben, habár akár így is felfogható. (Hiszen egy globális elme lehetősége több okból is elfogadhatatlan lehet, amennyiben pedig következik az eredeti elméletből - amint állításom szerint következik is -, akkor az eredeti elmélet is elfogadhatatlan lesz.) A dolgozat azonban a globális elme legalábbis elvi szintű plauzibilitása mellett foglal állást.

Ami a módszertant illeti, az absztrakt elemzések, gondolatkísérletek, filozófiai érvek mellett példák, analógiák, metaforák és címkék is felhasználásra kerülnek a meggyőzés szándékával és az érthetőség végett. Vizsgálatainkba emellett olyan kísérleti eredményeket is bevonunk, melyek az elmét és viselkedést kutató több tudományterületről származnak. Filozófiai célkitűzéseiből fakadóan a dolgozatnak természetesen nem célja, hogy állást foglaljon az utóbb említett területek szakmai vitáiban, ugyanakkor meglátásom szerint bizonyos eredmények felhasználása konstruktívnak tekinthető és érdemlegesnek rá, hogy 
filozófiai konzekvenciákat vonjunk le belölük. Ezen eredmények használatát az is igazolja, hogy vagy más filozófusok is támaszkodnak rájuk, vagy pedig párhuzamban állnak olyan eredményekkel, amelyekre a filozófiai szakirodalomban szokássá vált hivatkozni. Amennyiben az elemzésekbe bevont tudományos eredmények és elméletek valóban elfogadhatóak (aminek eldöntését, ismétlem, a dolgozat nem tekinti feladatának), úgy a gondolatmenet további alátámasztást nyer. Ugyanakkor a gondolatmenet nem ezeken a konkrét eredményeken áll vagy bukik, hiszen a csupán hasonló irányba mutató eredmények ugyanolyan mértékben alátámaszthatják azt. Mindenesetre az interdiszciplináris kitekintés önmagában is értékes lehet, amennyiben bizonyos konvergenciák és lehetséges szövetségek megjelennek különböző tudományterületek között.

A dolgozat szándéka a problémakör körüljárásán és továbbgondolásán túl egyfajta eltolódás elérése a kognícióról alkotott gondolkodásban. Az individualitás és internalitás nyilvánvalóan izgalmas és kutatásra méltó terület; de ha csak erre fókuszálunk, akkor a kogníciónak talán épp azt a mozzanatát vétjük el, mely tipikusan emberivé tesz minket, és amelynek evolúciós sikereinket köszönhetjük. A perspektívaváltási célt (felthetően túl ambíciózusan) ahhoz lehetne hasonlítani, amiről sok asztronauta beszámol, aki látta a Földet a saját atmoszféráján kívülről, melyet azóta overview hatásként ${ }^{3}$ ismerünk (White 1987). Vagy ahhoz, amikor a városainkról ürből készült, lélegzetelállító képeket nézünk, melyek a legtöbbször bármiféle felsőbb racionalitás nélkül rendeződnek nagyon is racionálisnak tünő struktúrákba. Túlságosan „,beszorultunk a saját fejünkbe”; ha azonban távolabbról vizsgáljuk a kogníciót, még az is kiderülhet, hogy a legnagyobb részét éppen, hogy kint hordjuk a testünkön kívül.

\section{Előzmények, kontextus}

\subsection{A cogitotól a modulokig}

Az a klasszikus kognitív tudományos és filozófiai paradigma, mellyel szemben a kiterjedt elme és a szituált kogníció egyéb elméletei önmagukat definiálják, karteziánus: azaz,

\footnotetext{
3 „Igazán transzformatív élmények, melyek közt az ámulat, áhítat, az egységérzet a természettel, transzcendencia és univerzális testvériség érzete is megtalálható" (Harrison és Fiedler, 2012, p. 29). Számunkra mindebből csupán az individualitáshoz és sokasághoz szokott perspektíva eltolódása érdekes az egység és az egymástól való függés irányába, nem pedig az ezzel járó érzések.
} 
több előfeltevésében Descartes szelleme él tovább (Rowlands 2010b, p. 10). E fejezet ennek a paradigmának a főbb mozzanatait veszi szemügyre: igyekszik felmutatni, miként csúcsosodik ki Fodor (1980) moduláris elméjének programadó elméletében, majd elkezdi belülről bontogatni a határait.

A karteziánus örökség négy releváns elemét Rowlands (2010b, p. 11) a következőkben fedezi fel: (1) az elme szubsztancia, (2) az elme a „fejben” van, (3) szubsztancia-dualizmus: test és elme különálló szubsztanciák, (4) szolipszista kiindulópont. Lássuk most ezeket bővebben kifejtve.

(1) Annak, hogy az elme szubsztanciaként kerül elgondolásra, két komoly következménye is van. Egyrészt szubsztancia az, ami ontológiailag független: önállóan, minden más nélkül képes létezni. Tehát az elmének nincs szüksége sem testre, sem a külvilágra; ha a külvilág hirtelen megszűnne, az elmében semmi sem változna. Másrészt az elme nem más, mint res cogitans, nem-fizikai létező, hanem „gondolkodó dolog”.

(2) Mivel az elme nem fizikai létező, ezért kiterjedése sem lehet, így elsőre értelmetlennek tünhet az elmét bárhová is elhelyezni a térben. Csakhogy a térben való elhelyezkedésnek két különválasztható aspektusa van: egyrészt a teret ki lehet tölteni, másrészt el lehet benne helyezkedni - utóbbi kiterjedés nélkül is lehetséges, ezt teszi például a geometriai pont. Azt, hogy az elmét az agyban lokalizálja Descartes, onnan sejthetjük, hogy a test-elme interakció magyarázatában az agyalapi mirigyet nevezi meg érintkezési pontnak. ${ }^{4}$

(3) Mivel a test res extensa, kiterjedt dolog, az elme pedig res cogitans, gondolkodó dolog, így fogalmi lehetetlenséggé válik a kettő interakciója, hiszen a kettő külön ontológiai kategóriát alkot, e két halmaznak pedig nincs közös tulajdonsága. A két terület között olyan szakadék tátong, melyet Isten nélkül nehezen lehet áthidalni.

(4) Igaz ugyan, hogy a szolipszista kiindulópont egy episztemológiai utazás része (hiszen az emberi tudás új alapjainak megtalálása a célja), mégis tovább mélyíti a test-elme ontológiai distinkcióját. Az elme ugyanis létezik, és mellesleg (ha épp úgy adódik) kapcsolatba lép a külvilággal. Ebben a képben az elme olyan „távol” van a külvilágtól, hogy onnan csak intellektuális bravúrral és Isten létének bizonyításával válik bizonyíthatóvá az extramentális világ léte.

Bár a szubsztancia-dualizmus megoldhatatlannak tűnő problémái motiválták a kognitív tudományok és elmefilozófiák egy monista ontológia irányába való eltolódását (az

\footnotetext{
${ }^{4}, \ldots$...azt hiszem, nyilvánvalóan felismertem, hogy az a része a testnek, amelyben a lélek közvetlenül gyakorolja a funkcióit, semmiképpen nem a szív, sem pedig az egész agy, hanem csupán az agy legbelső része, egy bizonyos, igen kicsiny mirígy..." (Descartes 1994, p. 51).
} 
elme nem-fizikai felfogásának elvetését), ennek nyomai továbbra is felmutathatóak. Lássuk, mely pontokban manifesztálódik Descartes szelleme.

(1) Az elme ugyan nem szubsztancia többé, mivel nem létezhet agy és idegrendszer nélkül, de dolog jellegét nem vesztette el: olyan dolog, mely számítógépként számításokat végez a környezeti ingerek inputjaiból, melyekből azután viselkedési outputokat generál.

(2) Az elme az uralkodó elméletekben továbbra is a „fejben” van, hiszen vagy (a) azonos az aggyal (identitáselmélet), vagy (b) kizárólagosan neurális alapon realizálódik (Rowlands 2010b, p. 10).

(3) A kogníció magasabb szintü folyamatai kizárólag agyi és idegrendszeri folyamatok, ezek pedig zárt rendszert képeznek; az olyan alacsonyabb rendủ folyamatok, mint amilyen az akció és percepció, tehát csak kauzális, nem pedig konstitutív viszonyban állnak vele. $^{5}$

A klasszikus kognitív tudomány hipotézise tehát az, hogy a kogníció ${ }^{6}$ vizsgálható egyfajta „módszertani szolipszizmusban” (Fodor, 1980): izoláltan, testi aspektusoktól, fizikai, szociális és kulturális kontextusoktól leválasztva.

Ezek az előfeltevések a kogníció olyan modelljét körvonalazzák, melyben a kogníció elkülönül az olyan alacsonyabb szintű folyamatoktól, mint a percepció és akció. Ez az úgynevezett „klasszikus szendvics modell” (Hurley, 1998). A kognitív jelenségekért tehát a lokális folyamatok tehetők felelőssé (például a diszkrét internális reprezentációkért specifikus és elkülöníthető agyi folyamatok felelnek, melyek pedig szelekciós nyomás és a gének eredményei), és a rendszeren kívüli elemek csak annyiban relevánsak, amennyiben szenzoros inputot biztosítanak, és lehetővé tesznek viselkedési outputokat (Wilson és Foglia, 2016). Percepció, kogníció és akció között oksági viszony áll fenn, de egymástól függetlenül konstituálódnak. Látható, hogy ez egy meglehetősen zárt rendszer: így lesz a zárt cogitoból egy majdnem ugyanolyan zárt „számítógép”. És bár a klasszikus kognitív modellt kritizálók főleg Descartes-ot szokták kárhoztatni sok prekoncepciónk miatt, érdemes felhívni a figyelmet rá, hogy a tabula rasa metafora szintén rendelkezik a zártság és rigidség, sőt, mármár az innátizmus bizonyos elemeivel. Az elme tiszta lap, amit a tapasztalat ír tele: de ez a lap már eleve valamilyen, ami meghatározza, hogy miként lehet rá írni.

\footnotetext{
5 A kauzális és konstitutív viszonyok közti különbségek áthatják “A kiterjedt elme” c. fejezet jelentős részét. Fókuszáltabb elemzéshez lásd: a "Konstitúció és kauzalitás” alfejezetet.

${ }^{6}$ Ez természetesen jelentősen eltér Descartes elmefogalmától, aki számára a cogito elsődlegesen bizonyos, közvetlenül adott, lelki szemünkkel megragadható, egyszóval: tudatos(ítható) tartalmakat foglal magában. Ezzel szemben a mai értelemben vett kognitív folyamatok jelentős része soha nem tudatosul.
} 
A klasszikus kognitív tudomány programadó elméletét Jerry Fodor fogalmazta meg, aki az elmét zárt modulok sokaságának gondolta el. Elméletében nem csak arról van szó, hogy percepció-kogníció-akció csupán kauzális viszonyban állnak egymással (ko-konsitutív helyett), hanem magán a kogníción belül is ilyen egymástól elkülönülő modulokat feltételez.

\subsection{Az elme modularitása}

Fodor Modularity of Mind címü (1983), programadó munkája a mai napig nagy népszerüségnek örvend, különösen kognitív tudósok és evolúciós pszichológusok között. ${ }^{7}$ És bár Fodor valódi álláspontja mérsékeltebb annál, mint amit sokszor provokatív állításai sejtetnek és amit a szakirodalomban tulajdonítani szokás neki, néhány követője mégis valóban képviseli ezt az álláspontot, így nem túl félrevezetö mindezt egy „fodori kalap” alá venni. A modularitás erős tézise szerint az egész elme erösen specializált modulokból épül fel. A gyengébb tézisek csak annyit állítanak, hogy az elme valamennyi része modulokból épül fel. (Maga Fodor sem gondolta például, hogy a magasabb szintü percepció vagy kogníció moduláris lenne.) Azért is lehet egy kalap alá venni e téziseket, mert lehet úgy érvelni, hogy az mind az erős, mind a gyenge téziseket érintse. Az alábbiakban végigfutunk az ezzel kapcsolatos néhány problémán. (Ennek részletesebb tárgyalását lásd például: McCauley és Henrich 2006.)

Prinz (2006, p. 22) a fodori elmeképet egy svájci bicskához hasonlítja, ahol az egyes szerszámok roppant behatárolt feladatok ellátására lettek kialakítva a szelekciós nyomás által. Fodor szerint az alábbi kritériumok mentén lehet elkülöníteni egy modult:

(1) Lokalizált: a megfelelő neurális architektúrán realizálódik.

(2) Képes külön károsodni, jellemző leállást produkálni.

(3) Automatikusan müködik.

(4) Gyorsan generál outputokat.

(5) Viszonylag egyszerü outputokat generál (pl. nem ítéleteket).

(6) Ontogenetikusan meghatározott: jellemző ütemben és sorban fejlődik ki.

(7) Terület-specifikus: inputok egy korlátozott osztályával foglalkozik.

(8) Hozzáférhetetlen: magasabb szintű folyamatok csak limitált hozzáféréssel bírnak a modulon belüli reprezentációkhoz.

\footnotetext{
${ }^{7}$ Pl.: Cosmides és Tooby 1994, Pinker 1997, Samuels 1998.
} 
(9) Információtól elzárt: a modult nem befolyásolhatják magasabb szintủ folyamatok információi.

Megoszlanak a vélemények arra vonatkozón, hogy az e listán szereplő tételek közül melyek esszenciálisak és melyek kevésbé fontosak ahhoz, hogy egy alrendszert modulnak tekinthessünk. Fodor (2000) későbbi munkáiban (9)-et tette meg nélkülözhetetlen feltételnek. ${ }^{8}$ Prinz szerint azonban a lista összes tétele problémás; sem külön-külön, sem együttesen nem jelölnek ki kutatás szempontjából releváns módon alrendszereket.

(1) és (2)-re utaló bizonyíték meglehetősen sok van. Még a köztudatba is átszivárgó közhely, hogy az agy egyes területeinek sérülése valamilyen mentális fakultás sérülésével jár: például a Broca-terület a nyelvi készségek csökkenésével vagy elvesztésével. De a sérüléseken túl a képalkotó eljárások révén kapott eredmények is a fakultások anatómiai lokalizáltságát támasztják alá első ránézésre: a kutatók láthatják, hogy különböző mentális feladatok elvégzésekor az agy mely részei aktívak. Csakhogy a helyzet nem ilyen egyszerü: valójában a kutatók még a képalkotó eljárások révén sem tudnak konszenzusra jutni például a Broca-terület pontos helyével kapcsolatban, ${ }^{9}$ olyannyira nem, hogy a nyelvképzés különböző aspektusait az agy számos zugában lokalizálni vélték már. ${ }^{10}$ Vagy vegyük azon eseteket, ahol két páciens agya ugyanazon a helyen sérült, mégis más hatások érvényesülnek náluk. Abból a belátásból, hogy egy agyterület sérülése bizonyos fakultás sérülésével is jár - bármily vonzó is egyenlőségjelet tenni a kettő közé -, még nem következik, hogy az a terület kifejezetten arra a feladatra lett volna specializálva. Léteznek olyan konnekcionista modellek, ahol a funkciók eloszlanak a hálózatban, mindenféle lokalizáció nélkül: és még egy ilyen modellben is lehetséges szimulálni meghatározott deficiteket néhány csomópont kikapcsolásával, anélkül, hogy azok a csomópontok az adott funkció locusai lennének. ${ }^{11}$ Mindebből Prinz nem azt a konklúziót akarja levonni, hogy az elme egy teljesen differenciálatlan neurális háló lenne, melyen teljesen eloszlanak a funkciók: szerinte is bizonyos fokú lokalizáltság jellemzi. Azt azonban állítja, hogy nem igaz az, hogy egyes agyterületek csak és kizárólag bizonyos funkciókért felelnek: tehát a lokalizáció ilyen erős tézise téves.

A modulokra Fodor szerint egy bizonyos fajta müködési stílus jellemző. Ezeket a (3), (4), (5) pont hivatott megnevezni; ezek pedig együtt is járnak a feltételezett modulokban. Tehát egy modul egyszerre müködik gyorsan és automatikusan, miközben egyszerü outputokat generál. Csakhogy ezek a tulajdonságok ritkán járnak együtt (vagy pedig olyan

\footnotetext{
${ }^{8}$ A masszív modularitás hívei föleg (6)-ot és (7)-et tekintik annak.

${ }^{9}$ Poeppel, 1996.

${ }^{10}$ Pulvermüller, 1999.

${ }^{11}$ Plaut, 1995.
} 
alrendszerre jellemzőek, amelyek fodori szempontok szerint is rossz jelöltek modulságra). Prinz példaként egyfelől a cirkadián ritmust hozza fel, mely automatikus bár, ám lassú, másfelől a szemantikus előfeszitésre (priming) utal, mely automatikus, de egyáltalán nem egyszerü outputot generál, ugyanis a konceptuális tudással van összekötve. És ha ezek a tulajdonságok együtt nem jelölnek ki elméleti szinten érdekes funkciókat, akkor külön-külön még kevésbé képesek erre. A legtöbb automatikus folyamat például kontrollálhatóakkal integrálódik, mint amilyen a színérzékelés (a színeket automatikusan érzékeljük, de szándékosan el is képzelhetjük őket).

(6): Fodor szerint a modulok biológiailag determináltak, innátak; tehát nem a tapasztalat révén, hanem elöre meghatározott módon fejlődnek. Csakhogy ez még a percepcióra sem igaz, ami pedig a legjobb jelöltje a modularitásnak. Legjobb esetben is csak az alacsonyabb szintű érzékelési mechanizmusok innátak, míg a magasabb szintű érzékelési mechanizmusok a környezettel való interakció révén alakulnak ki. ${ }^{12}$ Például a fantomfájdalmat érző betegek agyában a végtagérzékeléséért felelős sejtek újrahuzalozódnak, vagy a vakok agyának azon részei, melyek általában a látással vannak összefüggésben, átszervezik magukat, hogy Braille-t olvassanak. Chen és mtsai. (2002) arra mutatnak rá, hogy az érzékek plasztikusak, és a fentebbi esetekben is a környezeti input révén fejlődnek. Így tehát az ontogenetikus determináltság kitétel nem látszik megvalósulni az érzékelés terén. ${ }^{13}$ Mindez nem azt jelenti, hogy ne lennének specializált képességek: csakhogy ezek kialakulása konzisztens egy tanulási ívvel is, így nincs szükség feltételezni az innát alrendszereket. Specializáció létrejöhet e nélkül is, amint azt komputációs modellek is igazolják. Ezeknél a rendszer eredetileg nem rendelkezik specializált alrendszerrel, de az a feladat elvégzése alatt kialakul (Pl. Jacobs 1999, Thomas és Karmiloff-Smith 2002).

A terület-specifikusság (7) a következő tétel: ahhoz, hogy ez ne fulladjon trivialitásba, vagy ne váljon használhatatlanul homályos kritériummá, Prinz szerint csakis az erős olvasatában érdemes komolyan venni. Ebben az esetben az elsődleges vizuális kéreg sejtoszlopait vehetjük példaként, melyek tárgyak széleit, és valószínűleg csakis azokat hivatottak érzékelni. Egy mentális rendszernek tehát szintén így kellene müködnie, hogy e kritérium teljesüljön. De ez sem függetlenedik egészen más alrendszerektől: ha a szélérzékelés példánál maradunk, ezt használjuk egy olyan hétköznapi problémamegoldásnál, amikor a teli hütőbe akarunk betenni valamit. Továbbá a vizuálitásért felelős területek

\footnotetext{
12 Quartz és Sejnowski, 1997.

${ }^{13}$ Más területeken még rosszabb a helyzet, lásd bővebben: Slater és mtsai. 1990, Needham és Baillargeon 1993, Leslie 1994; Baron Cohen, 1995.
} 
sérülése a konceptuális kompetencia csökkenéséhez vezethet (Martin és Chao 2001), így az sem kizárt, hogy a konceptuális tudásunk egy része a vizualitásban tárolódik. De itt van a fentebb már említett példa is, amikor az egykor látásért felelős sejtek a taktilis érzékelésre szervezik át magukat, vagy az, hogy ugyanazon sejtek felelősek a hallásért és tapintásért. A látást nehéz tehát terület-specifikusnak gondolni. És ugyanez igaz más területekre is. Például a matematikai kogníció mögött meghúzódó agyi struktúrák szintén részt vesznek a nyelv, térfeldolgozás, és a fígyelem folyamataiban is. ${ }^{14}$ Meglehet, hogy e rendszereken belül akadnak kizárólag egy feladatra specializált alrendszerek, de az már nem tartható, hogy ez a nagyobb, modulnak feltételezett rendszerre is igaz lenne.

(8) és (9) újfent szorosan összetartozik: a modulok információ szempontjából zártak, mind abban az értelemben, hogy külső rendszerek nem férhetnek hozzá a rendszer belső információihoz, mind pedig abban, hogy a rendszer belső információra nincsenek hatással külső rendszerek információi. Én színeket és tárgyakat látok, ahhoz viszont nincs hozzáférésem, hogy milyen folyamatok révén jutok e színekhez és tárgyakhoz. (Belső mechanizmusainkhoz olyannyira nincs hozzáférésünk, hogy sokszor létezésük sem tünik fel.) A tudatosnak hitt döntéseink nagy része mögött tudattalan folyamatok állnak, a tudatosuló, racionalizált indokok pedig sokszor a narráló énünk lényegében alaptalan koholmányai. ${ }^{15} \mathrm{Az}$ introspekció e nyilvánvaló hiányosságai vajon azt is jelentik, hogy ezen alrendszerek (8) értelmében is elzártak? Nem: mindez csupán a tudatos hozzáféréstől való elzártságra ellenérv. De mi a helyzet a tudattalan hozzáféréssel?

Carruthers (2003) érve (8) mellett az, hogy ha egy rendszer hozzáférne egy másik rendszer belső reprezentációihoz, akkor azon reprezentációkat önmagának is reprezentálnia kellene, s így egyrészt redundánssá válna a két rendszer, másrészt minden rendszernek lényegében végtelen számú reprezentációt kellene tárolnia. Prinz joggal hívja fel a figyelmet rá, hogy mindez csak akkor igaz, ha a belső reprezentációk teljességére vonatkoztatjuk a hozzáférést. De miért ne volna elképzelhető, hogy egy külső rendszer csupán némely belső reprezentációhoz fér hozzá?

Végül pedig vegyük (9)-et, a legfontosabb tételt Fodor szemében. A perceptuális illúziókhoz nyúl, hogy bizonyítsa állítását, mint amilyen például a Müller-Lyer illúzió (két egyforma hosszúságú egyenest különböző hosszúságúnak érzékelünk attól függően, hogy a végükön lévő nyilak befele vagy kifele néznek). Abból, hogy az illúzió megmarad akkor is, amikor tudjuk, hogy a két egyenes egyenlő hosszúságú, Fodor szerint azt a következtetést kell

\footnotetext{
${ }^{14}$ Dehaene, 1997; Simon, 1997.

${ }^{15}$ Lásd: pl. Lee és Nisbett 1991. Ezt bővebben az „Elfogadhatatlan én-kép” alfejezet tárgyalja.
} 
levonnunk, hogy külső rendszerek nem képesek befolyásolni a rendszer belső információit. (Például az a hitünk, hogy a két egyenes egyforma, azt a percepciónkat, mely szerint nem egyformák.) Prinz erre egy, az illúziók tartósságát magyarázó másik elmélettel válaszol, mely azt az evolúciós előnyt jelentő mechanizmust feltételezi, mely a tapasztalat és hit közti ellentétek esetén a tapasztalatot teszi meg győztesnek. Ha nem lenne ilyen mechanizmus, a hiteink állandóak lennének, ugyanis lehetetlen lenne őket a tapasztalat által korrigálni. ${ }^{16}$

A külső rendszerek belső információra való hatására számos példát találhatunk. Scocchia, Valsecchi és Triesch (2014) azt mutatja be, hogy a zajos vagy kétértelmü ingerek esetén azt, amit adott pillanatban érzékelünk, befolyásolhatják többek között olyan kognitív és affektív aspektusok, mint a jelentés, előzetes tudás, motiváció és emocionális tartalom. Az olyan kétértelmü képek esetében, mint amilyen a „kacsa-nyúl”, szavakkal befolyásolni lehet, hogy az alany melyiket lássa. De ugyanez igaz auditorális input esetén is: egy teljesen érthetetlen, sőt, értelmetlen hallott szöveg, amennyiben feliratozásra kerül, hirtelen érthetővé válik (olyannyira, hogy az alany később már felirat nélkül sem képes máshogy hallani).

Vegyünk még egy példát, melyet Prinz maga szintén nem említ a gondolatmenetében, de bizonyára helyénvalónak tartana. Kulturális antropológusok és pszichológusok ${ }^{17}$ kimutatták, hogy egyes törzsek tagjai sokkal kevésbé receptívek a Müller-Lyer illúzióra, ${ }^{18}$ mint a nyugat-európaiak. Ezt két módon lehet magyarázni. Ha a percepció a természetes szelekció révén kialakított ontogenetikusan determinált agyi struktúrán alapul, ahogy Fodor gondolja, akkor erre a jelenségre biológiai különbségeknek kell magyarázatot adni. Ha viszont nincs anatómiai különbség például a !kung törzs és a nyugat-európai emberek között (ami valószínúsíthető), akkor azt kell feltételeznünk, hogy a percepció nem izolált moduláris rendszer: a felsőbb kognitív rendszerek valamilyen mértékü bejárással rendelkeznek oda, hiszen másként nem lehetne különbség az illúzióra való receptivitás között.

Prinz azonban tovább megy, és a „felülről lefelé” való információs átjárhatóság mellett az azonos szintű alrendszerek közti kommunikációra is hoz példákat. Ha alanyok olyan beszédhangokat hallanak, melyek inkonzisztensek az általuk látott szájmozgással, az eredmény szisztematikusan eltorzított hang $;{ }^{19}$ vagy a fantomfájdalom enyhíthető, ha egy tükör segítségével azt az illúziót keltjük az alanyban, hogy a hiányzó végtagját simogatja vagy

\footnotetext{
${ }^{16}$ E mechanizmus problémája ennél mindenesetre bonyolultabb, de erre most nincs módunk kitérni.

${ }^{17}$ Cole és Scribner, 1974.

${ }^{18}$ Egyéb illúziókra is eltérő fogékonyságot mutatnak, csak épp ez az illúzió a legelterjedtebb szakirodalmi példa.

${ }^{19}$ McGurk és McDonald, 1976.
} 
nyugtatja meg. ${ }^{20}$ Az érzékek közti átjárhatóság e példái is mind rontják (9)-et, a modulok információs zártságának koncepcióját.

Hangsúlyoznám, hogy Prinz nem tagadja, hogy létezhetnek fodori értelemben vett modulok: azt állítja, hogy ezek, ha vannak is, inkább a kivételt képező kisebbség, tehát e tulajdonságok nem jellemzők a különböző alrendszerekre, azok között ugyanis általában sok áthallás és kommunikáció van. Tehát Fodor kritériumlistája nem használható az elme mintegy „,izületeinél való” felszabdalásához. De lássunk még egy érvet a percepció kognitív penetrábilitása mellett és ellen!

Ez azért fontos, mert a korábban említett klasszikus kognitív modell élesen különválasztja a percepciót a kogníciótól és akciótól. Ezek az éles határok még jobban elmosódnak, ha rátérünk a percepció kognitív penetrábilitását jelző esetekre.

Egy másik motiváció a percepció és magasabb kognitív funkciók különválasztására a következő. Ha például egy organizmus azt látná, amit látni szeretne, amit remél, vagy amire számít, ahelyett, ami ott van, akkor rövid távon távozna az élök sorából (Fodor 1983). Az olyan gondolkodók szerint, mint Fodor vagy Siegel (2012), ha nem lehetséges „tiszta”, teóriamentes megfígyelés (theory-neutral observation) (tehát olyan percepció, melynek rendszerébe nem hatolhat be magasabb szintü folyamat), az magát az érzékelést teszi fölöslegessé.

Vagy vegyük például Siegel aggályát:

„Tegyük fel, hogy Jill azt hiszi, Jack mérges rá, és ez a hit azt eredményezi, hogy Jack (semleges) arca ténylegesen mérgesnek tünik számára. Ez az észlelet Jill számára további bizonyítékkal jár arra nézvést, hogy Jack mérges. Ez egy olyan körbenforgást eredményez Jill nézőpontjából, mely a penetráló hittel kezdődik, majd ugyanehhez a hithez tér vissza tapasztalat révén” (Siegel 2012, p. 202).

Ennek így valóban nem nehéz látni az evolúciós hátrányát. De, amint arra Lupyan (2015) hívja fel a figyelmet, a percepciót befolyásoló következtetések nem véletlenszerūek, hanem az organizmus tapasztalataiból táplálkoznak. Az organizmusnak például az a tapasztalata, hogy a leopárd csíkos, kifejezetten előnyére válik (ha olyan területen mászkál, ahol előfordulhatnak leopárdok), ha a „csíkosság” érzékelésére van kihegyezve a percepciós rendszere. Nem arról van szó, hogy akárhova csíkos leopárdokat képzelne, hanem arról, hogy hamarabb venné észre, ha az megjelenik. ${ }^{21}$ Amint azt Lupyan és Ward (2013) is kimutatta, a „tök” szó hallatán

\footnotetext{
${ }^{20}$ Ramachandran és mtsai. 1995.

${ }^{21}$ Az ilyen percepciós következtetés hibái jól látszanak pl. amikor a macska az uborkát kígyónak látja, és megijed. A macska nem a székre hiszi, hogy kígyó, hanem az uborkára, amely hasonlít rá.
} 
az alanyok nem a puszta levegőbe képzeltek tököket, hanem azok detektálásának ideje rövidült le. Jack és Jill példájára visszatérve Jill tehát nem látná oda a mérgesség jeleit Jack arcára, ha azok nem lennének ott; azonban könnyebben észre venné őket, ha mégis. ${ }^{22}$

A percepció ilyen felfogása ${ }^{23}$ nemhogy lehetővé teszi a rendszerek közti átjárást, de egyenesen nélkülözhetetlenné is teszi azt. Lupyan szerint az átjárható percepciós rendszer egyszerüen adaptívabb, tehát jobban képes ellátni a funkcióját, mintha nem lenne az. A teóriamentes megfígyelés pedig puszta vágyálom: a szenzoros adatok egyszerüen túlságosan többértelmủek ahhoz, hogy egy rendszer önmagában értelmet adjon nekik. A penetrábilitásra, tehát arra, hogy a modulok átjárhatók, meglehetősen sok kísérleti eredményt lehet felmutatni bizonyítékként; továbbá egy ilyen rendszer evolúciós előnyeit is láthattuk.

Összefoglalva a fentieket, arra jutottunk, hogy az elme moduljai nem olyan zártak, mint azt sok gondolkodó véli. Descartes számára az elme atomisztikus volt, de mi láttuk, hogy tovább boncolgatható: így jutottunk a modulokhoz, melyek azonban szintén nem bizonyultak a kogníció atomjainak, ugyanis müködésük nagyrészt a többi modul müködésétől is függ. És ha az elme moduljai ilyen nyitottnak bizonyulnak a rendszeren belül, vajon nem érdemes feltenni a kérdést, hogy az elme egésze mennyire lehet nyitott a rajta kívül zajló folyamatokra?

\subsection{Kinyitni a rendszert}

Láttuk tehát, hogy az úgynevezett modulok nem elzártak, müködésük nagyon is függ egymástól. Vajon milyen következtetéseket lehet levonni mindebből az elmére és a kognitív tudomány klasszikus „,szendvics” modelljére nézvést, mely percepciót, kogníciót, akciót egymástól elkülönülő, nagyon is zárt rendszereknek láttatja? A kérdést megfogalmazhatjuk úgy is, hogy nem áll-e fenn annak lehetősége, hogy a rendszer még nyitottabb, még átjárhatóbb, mint eddig gondoltuk?

Poppert idézve: „kellően rövid időtartam alatt [vizsgálva] egy organizmus [is] viszonylag zárt, majdnem, mint egy kristály” (Popper, 1977, p. 114). Itt az ideje, hogy az elmét más perspektívából is szemügyre vegyük. Azt a - fogamazzunk így - tér- és idősovonizmust, mely sokszor tudományos és filozófiai gondolkodásunkat jellemzi, érdemes

\footnotetext{
22 Továbbá, habár ezek összetettebb kérdésekhez vezetnek, amelyek megválaszolása nem tartozik a dolgozat célkitüzései közé, de kérdésként feltennénk: a placebo-hatás vagy a hipochondria jelensége nem szintén arra utalnak, hogy van olyan észlelés, amely erösen teóriaterhelt?

${ }^{23}$ A dolgozat jelen keretein belül nem térhetünk ki erre részletesen, de itt a percepció mint predikció nézetről van szó. A percepció nem passzív, hanem egy előrejelző rendszer. Lásd erről hosszabban: Lupyan 2015.
} 
lehet kritika tárgyává tenni, és szükség esetén megváltoztatni. Az alábbiakban azt próbálom bemutatni, hogy egy zártabb megközelítésmód nem csak az organizmusra vonatkoztatva lehet téves, de a kognícióra is. Az elme folyamatként, nyílt rendszerként való kezelése célravezetőbbnek bizonyulhat: nyílt, mégpedig nem csak „moduljai” számára, hanem a környezetére, a szituációkra is, melyekben müködik.

A következő kísérleti eredmények két tézist hivatottak alátámasztani. Egyrészt azt, hogy hétköznapi, intuitív gondolkodásunkban is ott bujkál a karteziánus szellemiség - ezt abból fogjuk látni, hogy az eredmények meglepőek -, másrészt azt, hogy mivel ezek a jelenségek csak problémásan vagy sehogyan sem illeszkednek a hagyományos elmekoncepció kereteibe, ezért annak revíziója szükségessé válik.

\subsubsection{Test az elmében ( embodied mind)}

Egy kísérletben csak angolul beszélő alanyoknak kellett kínai írásjelekről eldönteniük, hogy mennyire tartják őket vonzónak, miközben különböző attitűd-releváns motoros viselkedéseket produkáltak - az előttük lévő asztallapot vagy alulról nyomták fölfelé (pozitív valencia), vagy fölülről lefelé (negatív valencia). Az alanyok pozitívabban értékelték azokat a jeleket, amelyek nézése közben pozitívan hangolt motoros viselkedést produkáltak (fölfele nyomták az asztalt), mint amikor negatívan hangoltat (lefelé nyomták az asztalt), vagy pedig semmilyen motoros viselkedést nem hajtottak végre (Cacioppo, Priester és Bernston, 1993). Ez arra enged következtetni, hogy az attitüd-formálásban és ítéletalkotásban szerepet játszanak a motoros funkciók is.

Egy másik, szintén pozitív és negatív valenciájú szavakkal (pl. szeretet-gyülölet) végzett kísérletben az alanyoknak az volt a feladata, hogy az előttük lévő kart vagy maguk felé húzzák, vagy maguktól eltolják (Chen és Bargh, 1999). A reakcióidő jelentősen kisebb volt akkor, amikor a szó valenciája és a viselkedés összhangban volt (például a „,szeretet” szónál az alany maga felé húzta a kart, vagy a „gyülölet” szónál magától eltolta), mint amikor a szó valenciájával ellentétes motoros viselkedést kellett produkálni.

Ismét csak egy másik kísérlet a gesztusok kognícióra gyakorolt hatásait vizsgálta (Goldin-Meadow és mtsai, 2001). Két csoport gyereknek kellett először memorizálni egy szavakból álló listát, utána elvégezni egy matematikai müveletet, majd felidézni a memorizált listát: az egyik csoport szabadon gesztikulálhatott a matematikai feladat megoldása közben, a másik csoport tagjai azonban nem gesztikulálhattak. Azon csoport tagjai, akik nem 
gesztikulálhattak szabadon, jelentősen rosszabb eredményt értek el a szavak felidézésében. ${ }^{24}$ Mindez arra utalhat, hogy a gesztikuláció valamiképp elosztja vagy csökkenti a számolás kognitív terhét, így az alany nagyobb kapacitást tud biztosítani a memóriafeladatnak.

Ezek az eredmények azért illeszkednek nehezen a klasszikus modellbe, mert az a kogníció folyamatait (így például az ítéletalkotást és a memóriát) a percepció és akció alacsonyabb szintü folyamataitól elválasztotta; a szenzori-motoros agyi folyamatok csak kauzális viszonyban állnak a magasabb szintüekkel. A kép, melyet ezek az eredmények festenek, abba az irányba mutat, hogy kogníció, percepció és akció nem csupán kauzális, hanem ko-konstitutív viszonyban állnak, tehát egymástól függnek és egymást meghatározzák (Robbins és Aydede, 2009).

\subsubsection{Világ az elmében (embedded mind)}

A kísérletet végzők a Tetris nevü játékkal játszókat vizsgálták (Kirsh és Maglio, 1994). A játék lényege, hogy a lehulló kétdimenziós geometriai formákat úgy forgassuk el, hogy azok passzoljanak a lent már meglévő formákhoz, teljesen sík felületet alkotva ezzel. A lehulló formák ráadásul egyre gyorsabban jönnek, így a játékosnak egyre kevesebb ideje van eldönteni, hogy a forma hova passzol. A kísérlet azt mutatta, hogy a „profi” játékosok az elforgatás-gombot használva, fizikailag forgatják el a formákat, ahelyett, hogy ezt az operációt mentálisan végeznék el. Egy ezzel analóg kísérlet a bevásárlószatyrok bepakolását vizsgálta, és hasonló eredményre jutott: a gyakorlott bevásárló, ahogy az élelmiszerek jönnek a futószalagon, kategorizálja, és az alapján rendezi el őket a munkaterületen, hogy később milyen sorrendbe pakolja be őket a zacskóba, úgy, hogy ne sérüljön meg semmi a szállításkor (Kirsh, 1995).

A stratégia mindkét helyzetben hasonló. Ahelyett, hogy minden feladatot „fejben” oldanánk meg, elosztjuk a kognitív terhet (ezekben az esetekben a munkamemória terhét) a külvilágban. Ennek a jelenségnek a megragadására az episztemikus tett (epistemic action) fogalmát vezették be a szerzők (Kirsch és Maglio, 1994).

$\mathrm{Az}$ a tett episztemikus, melyet azért hajtunk végre, hogy megváltoztassuk a körülöttünk lévő világot oly módon, hogy az segítsen bennünket a keresésben és

\footnotetext{
${ }^{24}$ Azt az alternatív magyarázatot, mely szerint nem a gesztikuláció segít elosztani a kognitív terhet, hanem az okoz extra kognitív terhet, hogy figyelni kell arra, hogy nem lehet gesztikulálni, a kutatók azzal zárták ki, hogy voltak olyanok is, akik szabadon, ösztönösen nem gesztikuláltak - és az ő eredményeik is rosszabbak lettek azokénál, akik viszont igen.
} 
felismerésben, így csökkentve pl. az internális munkamemória terhét. Ezt megkülönböztethetjük a pragmatikus tettől, melyet azért hajtunk végre, mert a külvilág valamilyen fizikai változása önmagában kívánatos. (Például megigazítani az asztalt, hogy ne billegjen.)

Az episztemikus tettek nem holmi egzotikumok, melyekkel csak ritkán előálló vagy laboratóriumi körülmények között találkozhatunk. Képzeljük el, hogy ki kell raknunk egy puzzlet - egyetlen (igazságtalan) nehezítés van csupán: a darabokat nem forgathatjuk el és helyezhetjük át fizikailag; minden ilyen irányú operációt fejben kell elvégezni. Szórakoztató feladat helyett egy rémálomszerü kihívással találnánk szemben magunkat. Vagy képzeljük el, hogy keresünk valamit, ami sok, nagyjából hasonló doboz egyikében van. Hogyan járnánk el? Azokat a dobozokat, amelyeket már ellenőriztük, megjelölnénk valamivel (például rajzolnánk rá egy x-et), esetleg egy kupacba tennénk, hogy a dobozok fizikai elrendezése utaljon arra, hogy már megnéztük-e vagy sem, vagy inkább egyszerüen megjegyeznénk, hogy melyik dobozt ellenőriztük, és melyiket nem? Utóbbi igencsak valószínütlen.

E példákban az a közös, hogy amíg az agy bizonyos kognitív operációkat elvégez, addig néhányat „delegál” a külvilágba, s így a kognitív teher eloszlik. Egyszerüen könnyebb kirakni a puzzlet, ha átrendezhetem a darabokat, ahogy a dobozok közt is jobban tudok a keresésre koncentrálni, ha nem kell állandóan azt felidézni, hogy melyiket ellenőriztem már. Ez egy általános emberi tendencia; a hétköznapokban igencsak erősen támaszkodunk a külvilágra, hogy segítse kognitív vállalkozásainkat. Ilyenkor a „világ önmaga modelljéül szolgál" (Brooks, 1991, p. 140).

A kognitív szempontból drága internális reprezentációkat a percepció során is rendszeresen megspóroljuk azzal, hogy azokat „kint hagyjuk” a világban. Ezt remekül demonstrálja a változási vakságnak (change blindness) nevezett, jól dokumentált jelenség (Simons és Levin, 1997). Az ilyen kísérletek során általában egy rövid videót mutatnak az alanyoknak, akik vagy azért, mert más részletre fígyelnek, vagy azért, mert néhány másodpercre elsötétül a kép, egészen drámai változásokat sem vesznek észre a jelenetben. Ennek a jelenségnek talán leglátványosabb illusztrációja a következő (Chabris és Simons 2010): az alanyok annak számolását kapták feladatul, hogy két kosárlabda-csapat közül az egyik hányszor passzol, miközben a másik csapat próbálja megszerezni a labdát. Csakhogy a passzolgatás felénél besétál egy medvének öltözött ember a pálya közepére, és mindenféle dolgokat csinál, például integet vagy moonwalkol. Amire a kutatók kíváncsiak voltak, hogy az alanyok észreveszik-e ezt az igazán kirívó eseményt. Röviden: nem, mégpedig olyannyira nem, hogy legtöbben el sem akarták hinni, hogy ilyesmi elkerülhette a fígyelmüket. Ez két 
fontosabb dologra is utal. Egyrészt az, hogy a környezetünkről pontos internális reprezentációval rendelkezünk, illúzió. Másrészt az, hogy externális szituációkban tároljuk (és manipuláljuk) az információkat, olyan dolog, amelyet életünk nagy részében, szinte folyamatosan teszünk.

De a változási vakságot lehetővé tevő „tervezési” hibán túl is találunk a szemben olyan szuboptimális megoldásokat, melyek meglepővé teszik azt, hogy mennyire jól látunk a valóságban. O'Regan (1992) többek között az alábbi „illogikus” hibákat említi: a fénynek, mielött elérné az érzékelő sejteket, át kell verekednie magát a szemben található vérerek sürü hálóján; az uniformitás hiánya a retinában és foveában; a vakfolt megléte; a szakkádikus szemmozgások által okozott további pontatlanságok. Ahogy rámutat: „mindezen hiányosságok ellenére a látás tökéletesnek tünik számunkra. A mély [...] rejtélye annak, hogy miért látunk ilyen jól ilyen rémes vizuális apparátussal, továbbra is viszonylag felfoghatatlan marad" (p. 463).

A rejtély megoldása hasonló a már föntebb említett javaslatokhoz: nincs szükség se tökéletes látóapparátusra, se hatékonyabb internális memóriára, hisz a külvilág épp „,kéznél van” külső memóriaként, szinte mindig, amikor csak szükségünk van rá. Ahogy O'Regan később fogalmaz: „A percepcióval kapcsolatos sok probléma elpárolog, ha magunkévá tesszük a nézetet, miszerint az agynak nincs szüksége arra, hogy internális reprezentációt vagy replikátumot vagy «ikont» készítsen a külvilágról” (ibid.). Hiszen ott vannak elérhető közelségben.

Ami a test és a külvilág kognícióra gyakorolt hatásait illeti, az elméleteket felfüzhetjük az alapján, hogy milyen szerepet játszanak a kognícióban, illetve mekkora hangsúlyt fektetnek a kettő közötti interakcióra (Menary 2007). A test és megtestesülés (embodied mind) szempontjából a leggyengébben felfogható kapcsolatot test és elme között az internalista/individualista megközelítések feltételezik, melyek annyit állítanak, hogy az agy testi/megtestesült. A közepesen erős változat szerint némely kognitív folyamatok függenek a nem-neurális testtől: kauzális viszonyban állnak. A legerősebb tézis szerint pedig némely kognitív folyamatok és állapotok magukban foglalják azon folyamatokat, ahogy a test a környezetében cselekszik: konstitutív viszony (enaktivizmus) van közöttük.

A külvilág szerepét és hangsúlyát Menary az alábbi módon kategorizálja. Gyenge tézis: a kognitív folyamatok és állapotok inputjai és outputjai a külvilágban találhatók (internalizmus/individualizmus). Közepes tézis: a kognitív folyamatok és állapotok függenek a külvilágtól, támogatva vannak általa (kauzális viszony). Erős tézis: a kognitív folyamatok és 
állapotok integrálva vannak a külvilág állapotaival és folyamataival (konstitutív viszony). E legutóbbi tézis a kiterjedt elme tézise.

\section{A kiterjedt elme}

\subsection{Az eredeti gondolatmenet}

Az eddig említett eredmények és általuk körvonalazott elmekoncepciók még együtt sem jelentenek teljesen éles szakítást a klasszikus felfogással: ez a mélyebb, sokszor váratlan módon megnyilvánuló kapcsolat a kogníció, szenzori-motoros agyi folyamatok, a nemneurális test és a külvilág között még mindig tekinthető pusztán kauzális viszonynak. Vannak azonban olyanok, akik szerint konstitúciós viszony szükségeltetik ennek a mély viszonynak a leírására.

A kiterjedt elme koncepciója ${ }^{25}$ Clark és Chalmers (1998) cikkében az episztemikus tettek és kogníció kauzális viszonyát radikalizálja: szerintük az episztemikus tettek a kogníció részei, és így maguk is kognitívak. Mottószerüen: a kognitív folyamatok nem (csak) a fejben mennek végbe.

Clark és Chalmers egy intuíciós töltettel kezdik vitaindító szövegüket, mely a kognícióval kapcsolatos elöítéleteinket veszi célba. Vegyünk egy olyan egyszerü játékot, mint a Tetris. A játék lényege, hogy a lehulló kétdimenziós geometriai formákat úgy forgassuk el,

\footnotetext{
${ }^{25}$ Másik nevén aktív externalizmus. Az elnevezés a szerzőpáros által előzménynek tartott Putnam (1975) és Burge (1986) szövegekre utal. Putnam és Burge externalizmusa a jelentésre vonatkozik: ezek lényege röviden abban áll, hogy egy szó jelentését nem határozhatják meg pusztán pszichológiai, internális állapotok. Putnam híres „Ikerföld” gondolatkísérlete arra hívja fel a figyelmet, hogy elgondolható, hogy két ember (pl. én és a hasonmásom) ugyanabban a pszichológiai állapotban legyen, mégis más jelentése legyen ugyanazon szavuknak: tehát a jelentés nem lehet pusztán a „fejben”. Ez az externális struktúra azonban Putnamnél nem játszik kauzális szerepet a viselkedés szervezésében, épp ebben rejlik annak passzivitása: és ez alapján különbözteti meg Clark és Chalmers az aktív externalizmust. És bár a szerzőpáros valóban Putnam és Burge felöl pozícionálják saját externalizmusukat, van még egy szerző, akit méltó lehet az említésre mint előzmény. Ez a szerző Wittgenstein (1992), ugyanis ö sem gondolta, hogy valaminek érteni a jelentését egyenlő lenne azzal, mint egy adott pszichológiai állapotban lenni. Nyelvjáték-elmélete szerint a szavak jelentését nem azok a tárgyak adják, amelyet azok jelölnek, hanem a használatuk. Ahogy pedig a szavakat használjuk, az mindig egy interszubjektív közeg és az abban való tevékenység, gyakorlat eredménye. A nyelvjáték szabályai határozzák meg a jelentést, melyet a nyelvhasználók közössége formál. E gyakorlati aspektus miatt Wittgenstein talán még közelebb áll Clark és Chalmers externalizmusához, hiszen nála nem csupán arról van szó, hogy egy mentális reprezentáció korrespondál egy tárggyal vagy referál arra a külvilágban, mely tárgy kauzális-történeti aspektusai (is) meghatározzák annak jelentését, mint Putnam esetében. Az externalitás itt nem csak az internális tartalmakat határozza meg, hanem e tartalmak felhasználásának szabályait is, magyarán nem csak azt, amiről gondolkodunk, hanem azt is, ahogyan. A környezet kognícióban játszott aktív szerepére itt nem nehéz rámutatni. Ezek a párhuzamok mindenesetre hosszabb elemzést igényelnének, melyre itt nincs lehetőség.
} 
hogy azok passzoljanak a lent már meglévő formákhoz. E probléma-megoldásnak vegyük három esetét.

(A1) Az alany a lehulló darabokat mentálisan forgatja el, és e képzeletbeli elforgatás alapján dönt, hogy melyik alakzat hová passzol.

(A2) Az alany választhat, hogy mentálisan vagy az „elforgatás” gomb segítségével fizikailag forgatja el a darabokat. ${ }^{26}$

(A3) Az alany a cyberpunk jövőben rendelkezik egy neurális implantátummal, amely lehetővé teszi számára, hogy olyan módon és sebességgel forgassa el a darabokat, mint az „elforgatás” gomb segítségével az előző esetben. (Pl.: a retinájára kivetített kijelző segítségével.)

A kérdés az, hogy a három esetben mennyiben beszélhetünk kognícióról? (A1) a kogníció iskolapéldája (A2) intuitíve nem kognitív, ugyanis egy fizikai tettről van szó, amely a külvilágban eszközöl változásokat (A3) nagyon hasonlít (A1)-re, hiszen mentális forgatásról van szó, ugyanakkor (A2)-re is hasonlít, ugyanis a kikötés szerint az implantátum ugyanazzal a fajta komputációs struktúrával dolgozik. Az intuíciónk kisebb zavarba kerül, ezért Clark azt javasolja, vegyünk egy új esetet:

(A4) Egy intelligens földönkívüli faj tisztázatlan evolúciós okokból úgy fejlődött, hogy kognitív apparátusuk tartalmaz egy ugyanolyan Tetris-modult, mint az előző eset cyberpunk alanya: a különbség csupán annyi, hogy nem biotechnológiai, hanem tisztán biológiai ez a modul. ${ }^{27}$

(A4) amellett, hogy (már a kikötés miatt is) hasonlít (A3)-ra, (A2)-re is hasonlít. Így (A1)-et leszámítva mindhárom eset hasonló mértékben tünik kognitívnak, mégpedig a komputációs struktúra hasonlósága miatt - még ha a fizikai, tehát eredeti értelmében extramentális folyamat kognitív státusza meglehetősen kontraintuitív is első ránézésre. Mindenesetre a szerzők az esetek közti különbségeket, melyeket természetesen látnak és elismernek, felszínesnek tartják. Az alábbi elvet fogalmazzák meg, mely segítséget hivatott nyújtani abban, hogy mely extrakraniális folyamatok számíthatnak kognitívnak:

\footnotetext{
${ }^{26}$ Érdekesség, hogy a profi Tetris-játékosok tudattlanul is a fizikai elforgatás mellett döntenek, ugyanis Kirsh és Maglio (1994) becslése szerint kb. háromszor hosszabb ideig tart mentálisan forgatni, majd utána a helyére igazitani a leeső alakzatokat.

27 (A4) nem az eredeti 1998-as szövegben található, hanem egy azt ért kritikára érkező választanulmányban, Clark (2010a)-ban. Megvilágító ereje miatt azonban helyet kapott itt.
} 
A paritás elve [parity principle]: „ha egy feladat elvégzésekor a külvilág egy része olyan folyamatként funkcionál, melyet habozás nélkül a kognitív folyamat részének tartanánk, ha a fejben menne végbe, akkor a külvilág azon része ténylegesen a kognitív folyamat része" (Clark és Chalmers 2010, p. 29).

Ezen elv és szerepe sok félreértésre adott és ad okot, ezért kénytelenek leszünk vele a későbbiekben hosszabban foglalkozni - egyelőre elegendő annyi, hogy ha a kiterjedt elme hipotézis alátámasztásához önmagában nem is elégséges, az elmével kapcsolatos karteziánus intuícióinkat mindenképp megbolygatja.

Térjünk vissza az episztemikus tettekhez (melyeket Clark és Chalmers is fontosnak tartanak gondolatmenetükben), és az aktív externalizmushoz: abban az esetben, ha az externális elem is bevonásra kerül a kognitív folyamatba, és ezek megfelelő módon kapcsolódnak össze [coupling] a kogitáló alannyal, a szerzők szerint ez a hibrid rendszer (ugyanis intra-és extrakraniális elemet is tartalmaz) teljes joggal nevezhető kognitívnak.

A megfelelő összekapcsolódás [coupling] kritériumai a következők:

(1) Az elemek között (internális és externális) kétirányú interakció áll fenn.

(2) Minden elem aktív okságilag.

(3) A rendszer együtt úgy irányítja a viselkedést, ahogy a kogníció általában.

(4) Ha kivesszük az externális elemet, csökken az alany kompetenciája, mintha egy agyrészét operáltuk volna ki.

E kritériumokról később fogunk bővebben beszélni: nevezzük őket „A” kritériumoknak.

Aggályként merülhet fel, hogy eddig csak kognitív folyamatokról volt szó: mi a helyzet azonban az elmével? Ha igazán mentálisnak csupán mentális állapotok számítanak (hitek, vágyak, tapasztalatok, érzelmek, stb.), és ezeket kizárólag agyállapotok realizálják, akkor, még ha el is fogadjuk, hogy némely kognitív folyamatok az externális környezetben (is) zajlanak, ez vajmi keveset mond arról, hogy az elme kiterjedt lenne.

A szerzők ezért mutatják be következő gondolatkísérletüket, a híres-hírhedté vált Ottot és noteszét. A következőről van szó: Otto enyhe Alzheimer-kórban szenved, ezért mindig magánál hord egy noteszt, amelybe feljegyez olyan információkat, melyekre szüksége lehet. Otto arról értesül, hogy a New York-i Modern Művészetek Múzeumában olyan kiállítás van, amely érdekli, ezért úgy dönt, hogy elmegy megnézni. Mivel a múzeum címére nem emlékszik, megnézi a noteszt, amelyben látja korábbi feljegyzését: az 53. utcában van, ezért odamegy. 
Ezzel szemben Inga - akit ugyanúgy érdekel a kiállítás, és szintén úgy dönt, hogy megnézi - a biológiai memóriáját használja: egyszerủen felidézi, hogy a múzeum az 53. utcában van, és odamegy.

A szerzők szerint a két helyzet analóg: Otto és Inga egyaránt azért mentek az 53. utcába, mert úgy hitték, hogy ott van a múzeum. Inga a biológiai memóriájából idézte fel a helyszínt, Otto a noteszéből, azonban ez csupán felszínes különbség. Mindketten már rendelkeznek azzal a diszpozicionális hittel, hogy a múzeum az 53. utcában van - Inga azelőtt, hogy felidézné az emlékezetében, Otto azelőtt, hogy kikeresné a füzetéből. Az információt az teszi hitté, amilyen funkciót ez az információ betölt: s ha úgy irányítja a kogníciót és viselkedést, ahogy a hitek általában, akkor nincs okunk nem hitnek tartani pusztán azért, mert a koponyán kívül található. A mentális tartalmak szuperveniencia-bázisa tehát - némely esetben - a fejen kívül található, tehát: az elme kiterjed a külvilágba.

A szerzők megadják azon kritériumokat, amelyek alapján Otto és notesze kognitív rendszert alkot, s így a notesz információi Otto hiteinek számítanak, s amelyek alapján nem állíthatjuk (többek között) azt, hogy mindazon információkat tudjuk, amelyek pl. a könyvtárunk könyveiben találhatók, vagy azt, hogy akinek van Internet-hozzáférése, annak a Wikipédia összes szócikke részét képezi hiteinek és tudásának. Otto és a notesze a következő kritériumoknak felel meg:

(B1) A notesz megbízhatóan elérhetö és Otto rendszeresen használja.

(B2) Az információt, amit a jegyzetfüzetben talál, többé-kevésbé automatikusan jóváhagyja, tehát igaznak fogadja el. (Nem úgy, mint például a pletykákat.)

(B3) A noteszban lévő információk könnyen hozzáférhetök, amikor csak szükség van rájuk.

(B4) A noteszban lévő információkat valamikor a múltban tudatosan jóváhagyta, ennek következtében kerültek a noteszbe.

Ha egy externális tárgy és a kogníciót végző alany ezen kritériumoknak megfelelő módon áll kapcsolatban, akkor állíthatjuk - a szerzők szerint - hogy az alany elméje kiterjed a külvilágba. $^{28}$

${ }^{28}$ Gertler (2007) elegánsan a következöképp rekapitulálja a gondolatmenetet:

(1) Az információt az a szerep teszi hitté, amit betölt.

(2) A noteszban található információ pont úgy funkcionál (ugyanazt a szerepet tölti be), mint az információ, amely egy megszokott nem-okkurens hitet konstituál.

(3) Az Otto noteszében található információk hiteknek számítanak (1) és (2) miatt.

(4) Otto hitei részét képezik az elméjének.

(5) Az Otto noteszében található információ Otto elméjének része (3) és (4) miatt.

(6) Otto notesze a börén kívüli világhoz tartozik, vagyis az „externális” világhoz. 
A kiterjedt elme hipotézise nem véletlenül az egyik leghevesebb kortárs vita gyújtópontja, amely az elmefilozófia keretein is túlmutat. Az alábbiakban először a fontosabb ellenvetéseket fogjuk átnézni, ezek alapján pedig módunk nyílik részletezni és pontosítani az eredeti elképzelést, valamint a kiterjedt elme számunkra legvédhetőbbnek tűnő képének körvonalazása is lehetségessé válik ezek mentén.

\subsection{Ellenvetések}

Érdemes leszögezni, hogy mindegyik ellenvetéssel önmagában meg lehetne tölteni egy külön kötetet (amint ezt sokan meg is tették), így a fejezet ezek rövid bemutatására és a lehetséges válaszirányokra szorítkozhat csupán. Ezek számomra többé-kevésbé meggyőzőnek tünnek, de az ellenvetések és válaszok elemzései a legkevésbé sem tekinthetők teljesnek. Továbbá főleg azon ellenvetésekre helyeztem nagyobb hangsúlyt, amelyeket kevésbé tárgyal a szakirodalom, vagy tárgyal ugyan, csak épp másként.

\subsubsection{Konstitúció: de mié?}

Sok módon félre lehet érteni a kiterjedt elme hipotézist, és némely módok nehezebbek, mint a többi. Nézzük meg, mit is állít Clark és Chalmers egy ilyen félreértés alapján.

„Amikor ások egy gödröt, az ásó segít ebben a feladatban, és még az is lehet, hogy nem lennék képes kiásni a gödröt az ásó nélkül. De ez nem terjeszti ki az izomzatomat az izomzatomtól független dolgokba. Adams és Aizawa (2008) szerint ugyanez igaz mutatis mutandis a kognícióra és az externális tartozékaira" (Shapiro 2009).

Mutatis mutandis ez azt jelentené, hogy Otto notesze esetében Otto agya vagy központi idegrendszere kiterjed a noteszbe. Jóllehet Adams és Aizawa a szalmabábu-támadásaikkal (és olykor stílusukkkal is) némiképp megnehezítik, hogy a jogos ellenvetéseik méltó hangsúlyt kapjanak, ilyet még ők sem állítanak. (Szalmabáb pl., hogy a tollban és a DVD-lejátszóban

(7) Az elme kiterjed a világba (5) és (6) miatt. 
önmagában kogníció zajlik. Ezt a kiterjedt elme hipotézis legfanatikusabb képviselöje sem állítaná, de erre később visszatérünk.)

Arra, hogy az ásó és én esetemben $m i$ terjed ki az ásóba, ha nem az izomzat, Clark és Chalmers valami olyasmit mondana, hogy az ásórendszerem. Egy példával igyekszünk rávilágítani arra, hogy ez miért nem olyan abszurd, mint az első ránézésre tünhet.

Nem túl régi felfedezés, hogy a bélrendszerben található mikrobiom hatással van a központi idegrendszer müködésére. Olyan zavarok létrejövetelében is szerepet játszik, mint pl. a szorongás, depresszió vagy szkizofrénia (Clapp és mtsai. 2017). Kétirányú kommunikáció áll fenn a központi idegrendszer és a bél mikrobioma között, amely kapcsolatot agy-bél tengelynek nevezik. E példát többek között az teszi relevánssá, hogy a mikrobiom baktériumai nem humán sejtekből állnak: szimbiózisban élnek (olykor) az emberi testtel, de nem abból származnak. Az agy-bél tengely tehát bizonyos értelemben a testen „kívülre” terjed, mégis együttesen határozzák meg a központi idegrendszer müködését. Az agy-bél tengelyt kutató tudósokat valószínüleg kevésbé érdeklik metafizikai viták, Clark és Chalmers viszont erre feltehetően azt mondaná, hogy az agy és bél együttesen konstituálja azt a rendszert, amely a központi idegrendszer zavarait létrehozza, vagy épp nem hozza létre. A kettő kölcsönösen hat egymásra, koevolválódnak, stb. és ez Clark és Chalmers szerint a kognitivitással is így van: a központi idegrendszer és az externális elemek kölcsönösen hatnak egymásra (ez az ún. kognitív összekapcsolódás, erről még sokat fogunk beszélni), együtt fejlődnek. És mindez nem csak a filozófiai elméletalkotás során tarthat számot érdeklődésre, hanem kognitív tudományos vizsgálódások során is, melyek tárgya e kölcsönhatások megvalósulása. Véleményünk szerint a kiterjedt elme koncepciója, hiába épp a metafizikai súlya miatt okoz annyi felszisszenést a filozófustársadalomban, valójában a tudományos vizsgálódás hangsúlyeltolódása miatt igazán jelentős. Ahogy az agy-bél tengely kutatóit nem érdekli, hogy a mikrobiom metafizikai értelemben konstituálja-e a központi idegrendszert (csak az, hogy egymás nélkül nem értelmezhetők, így muszáj együtt vizsgálni őket), úgy a kiterjedt elme filozófusai és tudósai is tehetnek hasonlóan.

\subsubsection{Tudatosság}

További ellenvetéseknek lehet elejét venni azzal, ha tisztázzuk, hogy a szerzők mit állítanak még és mit nem. Az egyik első kézenfekvő tisztázandó dolog a tudatosság, a kválé kérdése, ugyanis elme hallatán sokan gondolunk elöször erre. Vajon az eredeti extended mind 
azt állítja, hogy a szubjektív tapasztalatok realizációs alapjai az agy és idegrendszeren túlra terjeszkednének? Nem, sőt „távolról sem tűnik plauzibilisnek, hogy a tudatosság a fejen kívülre terjedne" (Clark és Chalmers, 1998). De, amint felhívják rá a fígyelmet, a kogníció nem csupán tudatos folyamatokból áll, sőt, ami azt illeti, fỏleg nem tudatos folyamatokból áll. (Ha nem így lenne, nem lenne ilyen élénk vita pl. a modulok léte és természete körül, sőt, aligha lenne szükség a kognitív tudományokra mai formájukban, hiszen introspekció révén meglehetősen világossá válna a legtöbb kérdés.)

Másfelől Rowlands (2010a) kidolgozott egy olyan keretet is, melyben a tudatosság (egy adott fregei értelemben ${ }^{29}$ ) kiterjedhet a külvilágba, így ez a kérdés sem teljesen eldöntött. Rowlands okfejtése nem tisztán fogalmi-technikai ügyeskedés, álláspontja szerint Frege koncepciója eleve jobb a tudatosság bevett fogalmánál, és az történetesen nem csak az internalitást foglalja magában.

A tudatosságról azonban nem csak a fenomenológiai karakter értelmében beszélhetünk. Az Otto noteszében található hitek (amikor épp nem használja a noteszt), nem okkurens hitek; ahogy az elmében is vannak olyan diszpozicionális hitek, amelyeket az „elménk szemével” nem vizslatunk, nem tudatosulnak, csak „pihennek”. És mindez nem csak mentális állapotokra, de folyamatokra is igaz: ezek sokszor nem tudatosak, esetleg nem is tudatosíthatók soha (introspekció révén nem lehet megragadni őket.) A nem okkurens hitek és folyamatok intuitív módon részei az elmének, és épp ez a párhuzam teszi lehetővé, hogy a notesz információi csukott formában is Otto elméjének részét képezzék. Mondhatjuk azt, hogy igazi elmének csak az okkurens hiteket és folyamatokat tartjuk, ekkor viszont valószínűleg túl szükre szabjuk az elmét, amely szintén kontraintuitív. Erre bővebben a „Túl kicsi és túl nagy elmék" alfejezet tér ki.

Másrészről, amennyiben a funkcionalizmust komolyan vesszük, a tudatos tapasztalat kiterjesztése vajon nem lehet pusztán technológiai kérdés? Nem lehet pusztán annak kérdése, hogy képesek vagyunk-e olyan szubsztrátumot létrehozni, amely tárolni és müködtetni képes ilyen jellegü információkat, és ezt képesek vagyunk-e összekapcsolni a meglévő biológiai apparátussal? Nem a „lélek” egyfajta mágikus képe rezonál még az ettől való teoretikus ódzkodásban? A tudatosság tünik az utolsó karteziánus mentsvárnak, melyet még nem sikerült lerombolni, ezért ide menekítettük a (sokszor) reflektálatlan esszencialista, mágikus vágyainkat, de nem világos, hogy a tudatosság folyamatai miért lennének elvileg

\footnotetext{
${ }^{29}$ Frege 1892, 1918.
} 
reprodukálhatatlanok. E kérdés azonban hosszabb vizsgálódást érdemelne, amelyre itt nincs módunk.

A további ellenvetések a kiterjedt elme három kulcspontjának valamelyikét támadják:

- a paritás elve

- kognitív összekapcsolódás (coupling): „A” kritériumok

- intuitív kritériumok, megbízhatóság, integráció: „B” kritériumok.

\title{
3.2.3. A paritás elve és a különbözőségi ellenérvek
}

Az ellenvetések jelentős hányada az internális (biológiai) és externális memória közötti különbségekre támaszkodik, ezek felmutatásával szándékozik cáfolni, hogy a kettő ugyanahhoz a pszichológiai fajtához tartozhatna.

\begin{abstract}
„Amellett érvelek, hogy a »memória« állapotainak (folyamatainak) kiterjedt részei olyan mértékben különböznek az internális memóriától (az emlékezés folyamatától), hogy különálló fajtákként kellene kezelni őket; ez elejét veszi minden motivációnak, hogy a kiterjedt kogníció hipotézise mellett érveljünk durva hasonlóság miatt (nevezetesen, hogy kiterjedt kognitív állapotok olyanok, mint a teljesen internálisak; ezért ugyanazon magyarázati kognitív fajtához tartoznak; ezért vannak kiterjedt kognitív állapotok)" (Rupert 2004, p. 407).
\end{abstract}

„Clark és Chalmers 1998-as cikke erősen támaszkodik a paritás érvre, mely szerint amennyiben egy folyamat kognitívnak minősül, ha a fejben zajlik, akkor szintén kognitívnak kellene minősülnie, ha a világban hajtják végre" (Dartnall 2005, p. 135-136).

„Azt állítják [Clark és Chalmers], hogy a környezetbe kiterjedő aktív kauzális folyamatok épp olyanok, mint az intrakraniális folyamatok" (Adams és Aizawa 2001, p. 56).

A kiemelések tőlem származnak, és azt a célt szolgálják, hogy rámutassanak, hogy a kritikusok milyen jelentős összetevőjének látják a paritás elvét a kiterjedt elme hipotézisének, illetve milyen szigorúan értelmezik azt.

Első ránézésre érvényesnek tűnhet az ilyen jellegű érvelés; maga Clark is elismeri, hogy a fogalmazásmódjuk helyenként nem túl szerencsés, ugyanis teret enged a tartós félreértéseknek. Például amikor a Scrabble betűinek fizikai átrendezéséről van szó (mint externális folyamat), melyet feltevésük szerint lehetne egyszerübb módon elemezni, mint a 
hagyományos internális folyamatok, inputok és akciók sorával, akkor a következőt írják: „Amennyiben egy [a betük átrendezésével] izomorf folyamat a fejben menne végbe, nem éreznénk szükségét, hogy ilyen nehézkes módon jellemezzük” (Clark és Chalmers 2010, p. 29. Kiemelés tőlem). Ez alapján úgy tünhet, hogy az externális folyamatok kognitív besorolásának szükséges feltétele, hogy azok izomorfak legyenek a tisztán internális folyamatokkal. Hasonló a probléma az elv eredeti megfogalmazásában is: „ha egy feladat elvégzésekor a külvilág egy része olyan folyamatként funkcionál, melyet habozás nélkül a kognitív folyamat részének tartanánk, ha a fejben menne végbe, akkor a külvilág azon része ténylegesen a kognitív folyamat része.” (ibid. p. 29)

A paritás elve így értelmezhetővé válik a következő módon: egy externális folyamat csak akkor számít kognitívnak, ha kellőképp hasonlít (bármit jelentsen is ez) egy releváns, minden kétséget kizáróan kognitív (internális) folyamathoz.

Látható, hogy ebből az értelmezésből következik az is, hogy amennyiben az adott externális és a hozzá tartozó internális folyamatok között különbségeket mutatunk fel, akkor az előbbiek nem lesznek kognitívnak tekinthetők Clark és Chalmers logikája szerint. Ilyen implementációs különbségekre számos nyilvánvaló és kevésbé nyilvánvaló példát lehet hozni.

Adams és Aizawa például azt nehezményezi, hogy Otto vizuális és motoros funkciókat is mozgósít (felemeli a noteszt és belenéz) ahhoz, hogy hozzáférjen a hitéhez, míg Ingának nincs szüksége ilyesmire - ö introspekciót végez (Adams and Aizawa 2010, p. 55). De nézzünk meg néhány ennél kevésbé nyilvánvaló különbséget is.

\subsubsection{Egy vagy két lépéses rendszer}

Lehet azt mondani, hogy Otto emlékezési folyamata két lépéses, míg Ingáé csupán egy.

„Mindaz, amit Otto valóban hisz (kezdetben) az, hogy a cím a noteszban van. Ez a hit (1. lépés) vezet oda, hogy megnézi (2. lépés), amely aztán az (új) hithez vezet a valódi címet illetően" (Clark, 2010, p. 46).

Clark erre azt a választ adja, hogy Inga információ-előhívását is leírhatnánk két lépésben, még ha ez kicsit szokatlan is: Inga elöször csak azzal a hittel rendelkezik, hogy emlékszik az adott információra (1. lépés), majd pedig előhívja az információt (2. lépés). Amennyiben ez 
valóban túl szokatlan leírásnak tünik, lássunk erre egy másik - Clark által mellőzőtt - példát, ahol ez a leírás nem is olyan furcsa vagy fölöslegesen bonyolult.

A mnemonikus eszközök (melyeket a memóriamüvészek használnak és használtak már az ókorban is) egyik fajtája a memóriapalota ${ }^{30}$. A memóriapalota segítségével, ha meg kell jegyeznem egy számsort, pl. egy évszámot, ami legyen most 1822, akkor az így néz ki. Az egyes számokhoz különböző dolgokat rendelek, melyek alakjukat tekintve hasonlítanak rájuk. Pl. az 1-eshez gyertyát, 2-eshez hattyút, a 8-ashoz hóembert stb. Ezekből aztán igyekszem minél emlékezetesebb jelenetet gyártani, pl. a hóember riadtan menekül a gyertya elől, hogy ne olvadjon el (attól függően, hogy 18-at vagy 81-et kell megjegyezni, megtehetem a gyertyát vagy a hóembert a jelenet aktívabb résztvevőjének): majd mindezt elhelyezem egy jól ismert térben, pl. a gyerekkori otthon egyik szobájában. (Azért fontos, hogy jól ismert tér legyen, hogy ne kelljen erre is külön kognitív energiákat áldozni.) A maradék két számjeggyel ugyanezt teszem, további szobákban (pl. a két hattyú nyaka össze van csavarodva). ${ }^{31} \mathrm{~A}$ memóriaművészek több ezer elemből álló számsort is képesek pontosan fejben tartani e módszer segítségével. Ha emlékezni akarok az évszámra, fel kell idéznem a memóriapalotát, és sorban végig menni a szobáin: az emlékezetes jelenetek pedig felidézik magukat a számokat. Ha Inga ilyen módon jegyzi meg a MoMA címét, a legkevésbé sem lesz különös két lépésben leírni azt, ahogy előhívja a memóriájából. Először azt idézi fel, hogy elhelyezte-e a memóriapalotában (1. lépés), majd pedig magát a címet hívja elő (2. lépés). A memória ilyen használatára a kritikusok nyilvánvalóan nem mondanák, hogy nem kognitív, hiába áll két lépésből. És ebből is látszik, hogy valójában nem ez a fö probléma.

Clark azonban másik stratégiát választ, és nem az emlékezés két lépésből álló folyamatára keres plauzibilis példát, hanem azt mondja, hogy a két lépéses leírás azért fölöslegesen bonyolult Inga esetében, mert számára láthatatlan a saját memóriája: annyira hozzá van szokva a használatához, hogy az 1. lépést át is ugorja. De ugyanez igaz (lehet) Ottora, amint a példa is mutatja: annyira sokszor és automatikusan használja noteszét, amikor cserbenhagyja a biológiai memóriája, hogy az láthatatlan eszközzé válik számára. ${ }^{32}$ Amennyiben a két stratégia közül (a két lépést redukáljuk egyre a leírásunkban, vagy két lépésre hozunk minden kétséget kizáróan kognitív példát) különös módon egyik sem győzi

\footnotetext{
${ }^{30}$ Carruthers 1990, 2002, valamint Yates 1966. Mai kognitív pszichológiai kutatások: Moè és de Beni 2005.

31 Habár kontraintuitívnek tünik, hogy ezek az eszközök müködnek, hiszen ezáltal még több dolgot kell megjegyezni, mint eredetileg, valójában azonban sokkal könnyebb így emlékezni, és sokkal nehezebb elfelejteni is az információt. (Sőt, minél több érzékszerv játszik szerepet a rögzítésben, annál maradandóbb lesz az emlék.)

${ }^{32}$ De azt a kérdést is érdemes lenne feltenni a kritikusoknak, hogy mi a helyzet akkor, ha Otto és cyberpunk Inga folyamatait vetjük össze. Otto percepcióval jut hozzá hitéhez, melyet a füzetből hív elő; ezzel szemben Inga a kijelzőjéről olvassa le a megfelelö információt (mint a Terminátor c. filmben)? Ebben a helyzetben még nyilvánvalóbbnak tünik a hit lokációjának irrelevanciája.
} 
meg a kritikust, akkor sincs különösebb gond: a későbbiekben látni fogjuk, hogy az ilyen jellegű különbségek miért nem bírnak eleve különösebb jelentőséggel.

De térjünk vissza a „láthatatlanságra”. A két lépést úgy is fel lehet fogni, mint egyfajta zökkenést az emlékezés folyamatában: meglehet, hogy Inga biológiai memóriahasználatát le lehet írni úgy, mintha két lépésből állna, valójában azonban ez a rendszer olyan mértékben integrált, hogy fel sem tűnik neki, hogy két lépésből áll. Fel akarja idézni a címet, és már emlékezik is. Ezzel szemben a notesz soha nem lehet olyan mértékben integrálva a memóriarendszerbe, hogy elérjen egy olyan szintet, hogy láthatatlanná, zökkenömentessé váljon: Ottonak mindig bíbelődnie kell a notesszal.

Ezen ellenvetés megválaszolásának céljából érdemes elgondolkodni a testünkröl. Nem gyakran jut eszünkbe eszközként gondolni rá, pedig bizonyos értelemben a láthatatlanságig integrált eszköz. Miközben ezeket a sorokat írom, nem kell a finommotoros müködésre koncentrálnom, csupán a mondandómra, és a kezeim maguktól teszik, amit tenniük kell. De útban lehet: gyerekként, amikor írni tanultam, nem úgy mozgott, ahogy akartam, és most sem úgy mozog, ha valami fáj, eltörik, elromlik, netalán új, ismeretlen dolgot próbálok csinálni, például gitározni. Ilyenkor láthatóvá válik az addig láthatatlan. De önmagában ez a láthatóvá válás nem teszi a funkcionális rendszeren kívülállóvá a testrészt. Továbbá láthatatlanná válhat egy olyan eredetileg útban lévő eszköz, mint amilyen egy pár siléc, amely a maga majdnem két méterével és jelentős súlyával nem tűnik a legjobb jelentkezőnek erre. De gyakorlással nem csak, hogy nem lesz többé útban, teljesen láthatatlanná válik használója számára síelés közben, amely épp annyira teszi a dolgát „magától”, mint a teste, és kiterjesztett érzékelőként jelzi, merre vannak buckák és merre érdemes menni. Ha pedig ezek a példák sem lennének elég meggyőzők, akkor érdemes elgondolkodni a következőn.

Az elme annak a valaminek, amit a saját testének gondol, meglepő hajlandósággal rajzolja újra a határait. „A saját tested egy fantom, amelyet az agyad átmenetileg konstruált tisztán kényelmi okokból” (Ramachadran és Blakeslee 2012-őt idézi Clark 2003 p. 59). Ennek illusztrálására Ramachadran több nagyon egyszerü, de megvilágító erejü kísérletet is kitalált, amelyek közül egyet itt, egy másikat pedig lábjegyzetben talál az olvasó ${ }^{33}$. Kérjünk meg

\footnotetext{
${ }^{33}$ A guminyak kísérlet lényege (amelyet sajnos nehezebb kipróbálni otthon, mint a másikat), hogy egy virtuális valóság szemüvegen keresztül egy kamera révén látunk, ami pl. egy felhőkarocoló tetején van (New Yorkban). Ráadásul nem csak általa látunk, hanem a kamera érzékeli a mozgásunkat, és úgy forog, ahogy mi, tehát olyan, mintha mi magunk állnánk a felhőkarcoló tetején és nézelődnénk. A kamera azonban úgy van kallibrálva, hogy kicsit érzékenyebb legyen a mozgásunkra, tehát amikor elnézünk az egyik irányba, amennyire csak fizikailag képesek vagyunk, ő még tovább fordul, mintha 180 fokban hátra tudnánk nézni. Ez olyan érzést vált ki, mintha "gumiból" lenne a nyakunk és tetszőlegesen nyújtogathatnánk olyan irányokba is, amelyre fizikailag valójában nem képes. Az elme gyorsan azt a következtetést vonja le, hogy a nyakunk maga annyire hajlékony, mintha gumiból lenne.
} 
valalakit, hogy egy asztallap alá rejtett kezünket és az asztallapot tökéletes szinkronban érintse meg néha, ritmikusan koppintgasson rá (mintha morzézna), miközben mi csak azt látjuk, hogy az asztallapot érinti. Sokan (kb. az emberek 50\%-a) kezdik egy-két perc után úgy érezni, mintha az asztallap maga a börfelület része lenne: hogy valójában nem a kezén érzékeli az érintést, hanem az asztallapon. Ráadásul, ha az eddig csak morzézó ismerősünk hirtelen kalapáccsal rácsap az asztalra, megugrik a galvanikus börreakció, konzisztensen azzal, mintha a biológiai testet érö sérülésre számítanánk. Ramachadran így írja le a kísérletet ${ }^{34}$ :

„Olyan volt, mintha az asztal összekapcsolódott volna a hallgatók saját limbikus rendszerével, mintha az asztalt asszimilálták volna a testképükbe, olyannyira, hogy a fájdalmat és fenyegetést a saját testet érő fenyegetésként érzékelték, amint azt a galvanikus bőrreakció is mutatja" (Ramachadran és Blakeslee 2012, p. 61).

Az eszközhasználat során, amilyen pl. a síléc is, a korreláló akció és feedback hurkok azok, amelyek lehetővé teszik, hogy az agy a testkép határait átrajzolja és magába olvassza a nembiológiai komponenseket is. Clark egy idegtudományos kísérletet hoz példaként a fentiek alátámasztására, amelyben egy majom agyát vizsgálták, akinek egy gereblye segítségével kellett újra és újra élelemhez jutnia. „A sejtek vizuális receptív mezői az intraparietális sulcus anterior részében meghosszabbodtak az eszköz egy tengelye mentén, mintha a kéz képe magába olvasztotta volna az eszköz képét” (Iwamura 1998, p. 522-28. Kiemelés tölem.).

Vagyis nem csak mi emberek vagyunk képesek arra, hogy az agyunk úgy kezeljen externális tárgyakat, mintha a testünk része lenne, hanem egyéb állatok is, pl. majmok, mégpedig viszonylag gyorsan. Ahogy Clark fogalmaz: „Ésszerü azt gyanítani, hogy pontosan ez az a pont, ahol bizonyos fajta eszközök (a manuálisan alkalmazottak) láthatatlanná válnak a használatban" (Clark 2013, p. 62).

A mi érvelésünk számára mindebből az a releváns, hogy az agyunk maga képes és hajlamos úgy kezelni externális elemeket, mintha a test részei lennének; ilyenkor válnak ezek használatukban láthatatlanná. Nem könnyü belátni, hogy hasonló „láthatatlanná válás” miért ne valósulhatna meg a kogníciót segítő eszközöket illetően is (különösen, de nem kizárólag a

\footnotetext{
${ }^{34}$ Egy ehhez nagyon hasonló, és talán híresebb kísérlet ugyanezt az eredményt egy gumikézzel éri el. Ebben az esetben az alany nem az asztallapon, hanem egy gumikézen kezdi érezni az érintést, mintha az a teste része lenne (Botvinick és Cohen, 1998).
} 
technológiai fejlesztéseket is fígyelembe véve). Otto notesze ezeket a szempontokat fígyelembe véve lehet láthatatlan, az okostelefonjáról nem is beszélve. ${ }^{35}$

Azonban vehetünk az implementáció közti különbségekre még radikálisabb példát is: Otto hitei nem neurális architektúrán realizálódnak, szemben Ingáéval. Vagy: az extramentális hitek nem hoznak létre semmiféle változást az agyban diszpozicionális formájukban. Ez utóbbi példákat már valószínűleg a kritikusok is túl szigorúnak értelmeznék. És így jutunk el a fő problémához az ellenvetések e vonalával kapcsolatban.

A paritás elvének értelmezése, mely az ilyen különbözöségi ellenvetéseket lehetővé teszi, túl szigorú; olyan színben tünteti fel Clark és Chalmers gondolatmenetét, mintha mindenféle különbséget tagadni akarna internális és externális folyamatok között. Csakhogy nem ez a szándékuk. A kiterjedt elmének, ahogy a szerzők értik, nincs szüksége arra, hogy ,a folyamatok Otto és Inga esetében identikusak, vagy akár hasonlóak legyenek, ami implementációjuk részleteit illeti” (Clark és Chalmers 2010, p. 52. Kiemelés tölem.) De amennyiben nem azonosságról és hasonlóságról van szó, milyen értelemben kell e folyamatoknak izomorfnak lenniük? Egy példa megvilágító erejü lehet.

Vegyünk egy biológiai, tipikusan múködő emberi szívet; most pedig cseréljük ki gondolatban egy olyan mesterséges rendszerre, amely kontinuusan cirkuláltatja a vért, lüktetés és pumpálás nélkül. Az ember él, a vér eljut testének legtávolabbi zugaiba is - csak épp szívverése nincs. ${ }^{36}$ Mondanánk, hogy ennek az embernek nincs szíve? Ha olyan értelemben vagyunk funkcionalisták, ahogy Clark és Chalmers, akkor biztosan nem. Ugyanis szív alatt azt értjük, ami azt a funkciót látja el, amit a szívnek el kell látnia ahhoz, hogy szív legyen: hogy eljuttatja a vért a test legtávolabbi zugaiba is. Clark és Chalmers ilyen, funkcionális értelemben beszél izomorfiáról: Otto noteszének feljegyzései és azok használati módja funkcionálisan izomorf Otto releváns mentális állapotaival, konkrétan a diszpozicionális hiteivel. Egy mentális állapot akkor mentális állapot, ha betölti azt a funkciót, amelyet a mentális állapotok betöltenek. Így, mivel a fizikai attribútumok és az implementáció módja zárójelbe került, Otto noteszének feljegyzései mentális állapotoknak számíthatnak, ugyanis úgy müködnek.

A paritás elvének lényege nem az, hogy kijelölje az implementációs izomorfia mértékét, mely által kognitívnak ítélhetünk externális folyamatokat, vagy, hogy azt az elvárást támassza azokkal szemben, hogy épp olyanok vagy nagyon hasonlók legyenek, mint az

\footnotetext{
35 Gondoljunk arra a "mini-szívrohamra", amikor hirtelen nem találjuk a telefonunkat. Nem biztos, hogy alaptalan azt gondolni, hogy a galvanikus bőrreakció azt jelezné, mintha a konkrét testünket érte volna veszteség. ${ }^{36}$ A példát a preformansz-művész Stelarctól kölcsönöztem, aki egy interjúban említi.
} 
internálisak. Utóbbi valószínűleg soha nem fog megvalósulni, hiszen már eleve externálisak. Inkább intuíciós töltet, melynek célja, hogy megingassa a koponya kognitív határainak megingathatatlanságában lehorgonyzott intuíciónkat. Ahogy Clark írja róla: „eszköz ahhoz, hogy felszabadítsuk magunkat tisztán biosovinisztikus előítéleteinktől” (Clark 2005a, p. 2). Egyfajta „metabolikus tudatlanság fátyla”, mely arra szólít fel, hogy ne az adott folyamat locusa alapján döntsünk annak kognitív jellegéről. Így pedig az internális és externális folyamatok különbözőségére apelláló ellenvetések eleve célt tévesztenek, ugyanis szalmabábot támadnak.

Egyébként a kiterjedt elme hipotézis védelmezői közül többen nem csupán elhanyagolható jelentőségűnek tartják a paritás elvét, de kifejezetten károsnak, mert rossz irányba tolja el a hangsúlyt a gondolatmenetben, és inkább csak zavart kelt (Menary 2006, Sutton 2010, Wilson 2004). Erről a „Második hullám” fejezetben ejtünk bővebben szót.

\subsubsection{Különbségek, másként}

Az eddigi ellenérvek föleg az implementáció szintjén támadták Ottot és noteszét. Az ellenvetések most következő fajtája szintén különbségekre apellál, de nem az implementáció szintjén, hanem az információ fajtája vagy az ahhoz való hozzáférés szempontjából. Bár némi átfedés található az ellenvetések e fajtái között, a dolgozat szempontjából ez nem bír különösebb jelentőséggel.

Az ilyen jellegü ellenvetések közül némely annyira kézenfekvő, hogy Clark és Chalmers már az eredeti szövegben is megvizsgálta. Látni fogjuk, hogy ugyanaz a stratégia meglehetősen hatékonynak tünik mindegyik eset hatástalanítására.

Megbízhatóság, elérhetőség, sebezhetőség: lehet úgy érvelni, hogy Otto hozzáférésének módja a diszpozicionális hitéhez nem olyan megbízható, nem támaszkodhat rá oly mértékben, mint Inga. Ugyanis egy notesz elveszhet, elázhat, tönkremehet, ellophatják, átírhatják stb. Csakhogy az eredeti példát úgy alakították ki a szerzők, hogy a notesz meglehetősen megbízható legyen; Otto ugyanis rendszeresen használja. Az információhoz való hozzáférésének bizonyossága nem 100\%, de ugyanez elmondható Ingáról és bármely biológiai agyról is. Igaz, hogy az ilyen memória nagyobb biztonságban van, mint egy notesz, de azt is érheti baleset, szándékos manipuláció vagy tudatmódosító szer használata eltörölhet és átalakíthat információkat stb. A lényeg, hogy pusztán csak abból kifolyólag, hogy egy biológiai memóriarendszert ilyen hatások érhetnek vagy érnek, attól az még nem veszíti el 
kognitív státuszát, így pedig a notesznek sem kellene. Annak, hogy Otto notesze mennyire megbízhatóan elérhető lehet, a mai okostelefon-használatunk ékes példáját nyújtja. Igaz, hogy a telefon nem része biológiai apparátusunknak, de az is igaz, hogy szorongunk, ha épp nincs velünk, tönkre ment, nincs wifi, nem vagyunk elérhetők stb. Annyira hozzászoktunk az állandó eléréséhez, hogy nagyon feltűnik, ha kivételesen ez megszünik. (Ez a példa csak azt hivatott illusztrálni, hogy mai szemmel még könnyebb egy externális elemet olyan mértékben megbízhatónak gondolni, mint Otto noteszét.) Továbbá ez az eszköz akkor sem lenne sokkal gyakrabban, megbízhatóbban elérhető, ha történetesen az egész telefon egy implantátum lenne az agyban: ebből a szempontból nem számít különösebben ${ }^{37}$, hogy internális vagy externális-e az elem, és ezért nem kell, hogy számítson Ottonál és a noteszénél sem.

Inga hozzáférése a hitéhez privilegizált ${ }^{38}$ : csak ő fér hozzá, Otto diszpozicionális hitét azonban mások is láthatják. Ez azonban bármilyen szembeötlő különbség, egyrészt nem releváns abból a szempontból, hogy kognitívnak tekinthető legyen egy folyamat, amely ilyen externális elemet tartalmaz, másrészt nem is feltétlenül igaz. Vegyük például azt a tudományos-fantasztikus toposzt, amikor valakinek az emlékeiröl kiderülnek, hogy nem is a sajátjai: valaki más emlékeit kapta meg. Változtat-e bármit ezen emlék kognitív státuszán, ha más is rendelkezik vele? Ha akárhányan rendelkeznek ugyanazzal az emlékkel? Ebben az esetben két személy ugyanazon emlékekhez fér hozzá, így azt nehéz privilegizáltnak gondolni. Mondhatnánk erre azt, hogy egyáltalán nem biztos, hogy lehetséges ugyanazon emlék előhívása két különböző személy számára, hiszen ahogy érintettük is korábban, az emlékezés konstruktív folyamat, és a pillanatnyi mentális állapotok is befolyásolják. Tehát, ha két személy akár még ugyanúgy raktározná is el az információt, előhívni már nem biztos, hogy képesek lennének ugyanúgy (sőt, valószínüleg nem lennének képesek). Csakhogy ezt az ellenvetést ki lehet küszöbölni egy gondolatkísérlettel, amely az emlékezés folyamatainak kontingens törvényszerüségeit zárójelbe teszi. Helyezzük Inga és Otto példáját az Ikerföld jól ismert, Putnam által leírt gondolatkísérletének kontextusába. (Ami azt illeti, tetszőleges számú Ikerföldet is elgondolhatunk.) Inga és Inga hasonmása ugyanazon emlékekkel rendelkezik, és mivel mindenben hasonlítanak egymásra, abban is megtévesztésig fognak, hogy egy adott emléket miként hívnak elő. Az emlék kognitív jellegét érintő intuíciónknak számít, hogy Inga

\footnotetext{
37 Olyanoknál számíthat, akik gyakran ejtik le vagy veszítik el a telefonjukat. Csakhogy ez nem lényegi különbség, hiszen bizonyos agyi funkciókra is igaz lehet, hogy egyes embereknél gyakrabban sérülnek vagy csökken a kapacitásuk (gondoljunk ismét a tudatmódosító szerekre).

${ }^{38}$ A privilegizált hozzáférés másik lehetséges értelme az, hogy az információhoz való hozzáférésnek van egy fenomenális karaktere, milyensége, amely csakis E/1-ben hozzáférhető: csakis Inga tudja, hogy számára milyen felidézni azt, hogy mi a MoMA pontos címe. Csakhogy ez igaz lehet Ottora is: neki is valamilyen kinézni a noteszböl a MoMA címét, és a kválé nála is teljességgel hozzáférhetetlen E/3 személyü leírások számára, így ebben az értelemben nincs különbség a két eset között.
} 
és Inga ${ }^{2}$ sőt, akár Inga ${ }^{\mathrm{n}}$ is hozzáfér ugyanazon emlékekhez? Aligha. A privilegizált hozzáférés tehát nem lehet sarokköve annak, hogy mi számít kognitívnak és mi nem. ${ }^{39}$

Preston (2001, p. 360) azt nehezményezi, hogy a hitek általában olyan dolgok, melyek fölött az alany első számú tekintéllyel bír; nincs szükség vagy lehetőség arra, hogy valaki (akár én magam egy későbbi időpontban) kijavítson a hitemmel kapcsolatban vagy ellentmondjon neki, már ami a propozicionális attitűdömet illeti (az, hogy a hitem megfelel-e a valóságnak, egy másik kérdés). Otto ezzel szemben, mielőtt megnézné a noteszt, nem tud válaszolni arra a kérdésre, hogy mit gondol, hol van a MoMA. Való igaz, hogy a hit szokványos koncepcióját ez a szcenárió szétfeszíti. Csakhogy épp ez a lényeg: Otto és a notesz együttesen képez kognitív rendszert. Elgondolható továbbá olyan tisztán internális emlékezési folyamat, melyben az illető nem tud spontán módon nyilatkozni saját hitének tartalmát illetően, csak arról, hogy van-e ilyen jellegü hite. Gondoljunk a „két lépéses” ellenvetés során tárgyalt memóriapalotára. Ilyen helyzetben elgondolható, hogy első lépésben csak arra emlékszem, hogy valamilyen információt elraktároztam ily módon (pl. egy évszámot), de ahhoz, hogy felidézzem, végig kell mennem képzeletben a szobákon. Ez pedig már meglehetős hasonlóságokat mutat Ottoval, aki adott esetben a címre nem, de arra emlékszik, hogy leírta a címet.

A hitek egymáshoz való viszonya is másként alakul a tisztán internális és externális elemeket is tartalmazó rendszerekben, ez tehát alkothatja a lehetséges ellenvetések egy másik alapját. Két ellenvetés is besorolható ebbe a kalapba: az első Weiskopf (2008) észrevétele, a második (tudomásom szerint) kevésbé szerepel a szakirodalomban.

Weiskopf problémája a következő:

„A hitek (...) normális esetben információsan integrálva vannak egymással, és más hitekkel együtt frissítésre kerülnek (az egyén egyéb mentális állapotaival is, mint amilyenek a vágyak). De a legtöbb externálisan megtalálható, állítólagos mentális állapot nem rendelkezik ezzel a jellegzetességgel" (Weiskopf 2008, p. 5).

Tehát, szól Weiskopf következtetése, az externálisan tárolt információk nem hitek, azok ugyanis mindig egy rendszer részét képezik, amely „episztemikus egyensúlyát” integrációs és frissítő folyamatok biztosítják. A hiteink „,információs integráltsága” alatt meglehetősen hétköznapi dolgot kell érteni. Például, egyik ismerősünkről kiderül, hogy ő lett az Amerikai

\footnotetext{
${ }^{39}$ Az álláspontnak, miszerint a mentális kritériuma az E/1 személyủ, privilegizált hozzáférés lenne, monográfia terjedelmủ kifejtését lásd pl. Farkas 2008, illetve a kiterjedt elmével szembeni ellenvetésként pl. Gertler 2007.
} 
Egyesült Államok elnöke. Ezzel az új információval első körben megváltozik pl. az ismerősünk munkakörével kapcsolatos, vagy az amerikai választók épelméjüségébe vetett hitünk. De a háttérben, akár annak tudatosulása nélkül, megváltozik az ismerösünk lakcímét érintő hitünk is. Meglehet, hogy ez a változás csak akkor tűnik fel, amikor később az ismerősünk lakcíme iránt érdeklődnek, ugyanis a hitrendszereink sokszor (de nem mindig), automatikusan és tudatalatt ${ }^{40}$ frissülnek az új információk fényében. Jól látható, hogy a hitrendszer ilyen együttes változása nem valósul meg externális elemek esetében. Inga biológiai memóriájában a múzeum pontos helye frissül, ha megtudja, hogy a múzeum leégett, mégpedig az 53. utcáról a seholra. Ezzel szemben tegyük fel, hogy Otto, akinek a noteszében ott van a múzeum címe, nem írja fel, hogy a múzeum leégett, ezért ezt elfelejti. Amikor pedig legközelebb meg akarja látogatni a múzeumot, az 53. utcába fog menni, nem pedig sehova, hiszen a múzeum helyét nem írta felül, nem alakította át semmilyen, a mentális állapotokra jellemző frissítő mechanizmus.

Weiskopf egyébként érdekes módon nem elvileg utasítja el az externális mentális állapotok lehetőségét, azt azonban állítja, hogy azok de facto sokkal kevésbé elterjedtek, mint ahogy az Otto és notesz példa láttatja. Egyrészt egy olyan externális modult, amely rendelkezik egy olyan algoritmussal ${ }^{41}$, amely fenntartja az általa tárolt hitek integráltságát, tehát frissíti a releváns hiteket új információk fényében, genuin módon a mentális világ részének gondolná. (Természetesen csak akkor, ha ez a modul megfelelő módon össze is lenne kötve egy biológiai aggyal.) Ilyen technológia, ha lehetséges is, aktuálisan nem létezik. Másrészt, egy másik lehetőség, hogy Otto noteszét közelítjük egy ilyen algoritmus által frissített hitrendszerhez: ha feltételezzük, hogy Otto rendszeresen elejétől a végéig átnézi a noteszt, és a releváns hiteket a később noteszbe került információk alapján javítja, mivel a frissítő mechanizmus konkrét implementációja mellékes, a noteszben tárolt információk sokkal inkább elfogadhatók lesznek mint mentális állapotok.

Az ellenvetések egy további lehetséges stratégiája szintén a hitek egymáshoz való viszonyán, pontosabban az egymásnak expliciten ellentmondó hiteken alapul. Egy noteszben ugyanis könnyen megférnek egymás mellett ilyen hitek. Ha pl. Ottot egyik nap megbántja Inga, másnap pedig kedves vele, Otto pedig hajlamos megfeledkezni arról, hogy Inga milyen is valójában, akkor egyik nap azt írja fel, hogy „Inga goromba”, másnap pedig azt, hogy „Inga kedves”. Vagy a noteszben egyaránt szerepel, hogy a MoMA az 53. utcában van és az, hogy

\footnotetext{
${ }^{40}$ A hitek közti inkonzisztenciák kiszürése természetesen lehet tudatos munka is.

${ }^{41}$ Ennek az algoritmusnak egyébként Weiskopf szerint sem kell ugyanolyannak lennie, mint az emberi pszichológiai architektúrában; elég, ha hatását tekintve olyan.
} 
nincs sehol, hiszen leégett. Ezen esetekben az egymásnak ellentmondó hiteket egyaránt hinné Otto, csakhogy az ilyen explicit ellentmondások csakis szélsőségesen irracionális ágensekre lehetnek jellemzők. Weiskopf szerint tehát vagy azt mondjuk, hogy az externálisan tárolt információk nem hitek, vagy azt, hogy hitek, csak az ágens, aki rendelkezik velük, kivételes mértékben irracionális. A kiterjedt elme propagálóinak természetesen utóbbit sincs szándékában elfogadni (az elsőt pedig nyilvánvalóan nem: épp ez a vita kiindulópontja), hiszen azt mondják, hogy Otto notesze ugyanolyan funkciót tölt be, mint Inga memóriája ezzel pedig az is együtt jár, hogy Otto ugyanolyan racionális ágens, mint Inga.

Két módon is hozzá lehet látni ezen ellenvetés hatástalanításához. Egyrészt kimutathatjuk, hogy a normális, nagyrészt racionális biológiai agy is fenntart egymásnak expliciten ellentmondó hiteket, másrészt szigoríthatjuk Otto noteszhasználatát, hogy racionális ágensnek minősülhessen.

Az első mód nehézkesebb, habár nem teljesen reménytelen. Valószínüleg egy racionális biológiai agy nem dolgozik ilyen mértékủ explicit ellentmondásokkal, legalábbis nem olyan könnyedséggel, mint a notesz, amelyben $p$ és nem-p probléma nélkül megférnek egymás mellett. Például a kognitív disszonanciával ${ }^{42}$ járó feszültség is abba az irányba hat, hogy az egyén az ellentmondó hitek közül az egyiket elvesse. De talán mégis találhatunk olyan példákat, ahol az emberek inkább fenntartanak párhuzamosan egymásnak ellentmondó hiteket, minthogy azt megpróbálják feloldani. Pl. Isten mindenható és jó, de létezik a Sátán; állatoknak fájdalmat okozni rossz, a húsipar sok fájdalmat okoz állatoknak, fogyasztom a húsipar termékeit, de ezzel nem teszek rosszat. (Valószínűleg az ilyen ellentmondások mögött is a kognitív disszonancia feszültsége áll, pl. az ellentmondások feloldására tett kísérlet még nagyobb feszültséghez vezetne, de ez nem tartozik a tárgyhoz.) A lényeg, hogy explicit ellentmondásokra a biológiai agy nem szeret gondolni, de ez nem jelenti azt, hogy ilyenek egyáltalán nincsenek. ${ }^{43}$

Ami Otto noteszét illeti: minél több információ van benne, annál hasznosabb, ugyanakkor éppen e méret növeli a belekerülő inkonzisztenciák valószínűségét is, hiszen így nehezebb számon tartani, hogy az újonnan noteszbe kerülő információ konzisztens-e a korábbiakkal. Ezzel pedig egyenes arányban növekszik az ágens irracionalitásának mértéke is. Clark és Chalmers erre nem tér ki az eredeti szövegben, de talán nem nehéz kitalálni egy

\footnotetext{
A kognitív disszonancia a következőt jelenti:

“(1) A kognitív elemek között lehetségesek disszonáns vagy 'nem megfelelő' kapcsolatok. (2) A disszonancia jelenléte a disszonancia redukciójára, illetve a disszonancia növekedésének elkerülésére irányuló nyomást idéz elő. (3) Ezen nyomás megnyilvánulhat viselkedésbeli és kognitív változásokban, valamint az új információkkal és véleményekkel szemben tanúsított óvatosságban" (Festinger 2000, p. 76).

${ }^{43}$ Weiskopf a fanatikusok hiteit hozza hasonló példának.
} 
lehetséges válaszukat erre az ellenvetésre. Habár nem beszélnek expliciten egy olyan jellegü frissítő mechanizmusról, amely szüri az ilyen inkonzisztenciákat, ugyanakkor a kritériumaik között szerepel, hogy Otto tudatosan jóváhagyja a noteszbe kerülö információkat, így később igaznak fogadja el azokat. Ahhoz, hogy Otto jóváhagyjon egymásnak ellentmondó hiteket, már eleve irracionálisnak kellene lennie: ilyen hitek e kritériumok szerint ugyanis csak így kerülhetnek a noteszbe. De nem is feltétlenül az a lényeg, hogy konkrétan a $p$ és nem-p szerepel-e a noteszban, hanem az, hogy Otto tudja-e használni a noteszt. Ha Otto szeret sokszor meglátogatni egy gyakran költöző vándorcirkuszt, akkor a notesze tele lesz a cirkusz címeivel. Ha nem lenne valamiféle módszere arra, hogy használhatók legyenek az információk, akkor a notesznek sem lenne értelme. Így például használhat egy olyan „algoritmust”, miszerint a későbbi bejegyzések felülírják a korábbiakat, így tehát a vándorcirkusz ott van, amit a legutolsó bejegyzés állít, nem pedig ott, amit az előtte lévő tucat másik. Az inkonzisztens hitek növekvő száma nem irracionálisabbá teszik az ágenst, hanem használhatatlanabbá az externális memóriát: a többé-kevésbé racionális ágens pedig használható externális memóriára törekszik.

Egy másik gyakori, hasonló ellenvetés szerint (pl. Rupert 2004, Adams és Aizawa 2001) Otto memóriájára egyszerủen túlságosan másmilyen szabályszerűségek érvényesek, mint Ingáéra. ${ }^{44}$ A noteszban található információk statikusak; diszkrét módon vannak tárolva és nem vesznek részt kognitív folyamatokban az utóbbiakra jellemző diszpozicionális formában. A memóriáról alkotott olyan kép pedig, ahol az elraktározott információk passzívan várják, hogy felidézzék őket, mára meghaladottá vált. A biológiai memória ugyanis konstruktív, aktív folyamat, a benne tárolt információk változnak, újrarendeződnek, összeolvadnak, részt vesznek asszociációkban, ráadásul előhívásuk lehetőségének mértékét nagyban befolyásolja az, hogy jelenleg milyen hangulatunk, céljaink és hiteink vannak (Roediger és McDermott 1995, Roediger és mtsai. 2001).

További példának felhozhatjuk az „Elfogadhatatlan én-kép” alfejezetben hosszabban kifejtett csúcsérték-végső érték szabályt, amellyel a biológiai memória mint szabályszerüséggel rendelkezik, ellenben pl. egy retinába épített kamera által felvett implantátumban tárolt felvétel biztosan nem rendelkezne, vagy egy noteszben található nagyon részletes, valós idejü élménybeszámoló sem. Ilyen pszichológiai törvényszerüségnek említhetjük a primácia- és recenciahatást is, melyek lényege, hogy egy megjegyzendő szavak listájának elején és végén található szavakat könnyebben jegyezzük meg, mint a köztes

${ }^{44}$ Ezt az ellenvetést egyaránt elemezhettük volna a „Természetes, tudományos és pszichológiai fajták” alfejezetben is, önkényes alapon került inkább ide. 
elemeket. Ezekre az aggályokra azt a választ lehet adni, hogy lehetséges olyan hipotetikus rendellenesség, mely azt okozza, hogy valakinek a fentebb említett, statikus módon müködik a memóriája - mint ahogy a memóriát korábban eleve statikusnak volt szokás gondolni. Ebben az esetben aligha mondanánk, hogy az illető nem végez kogníciót: legfeljebb azt mondanánk, hogy a kogníciója (legalábbis, ami a memóriáját illeti) másként múködik. De el lehet képzelni olyan adathordozó eszközt is, amelyre olyan információkat tölthetünk, amilyeneket Otto a noteszébe; csakhogy ez az adathordozó úgy tárolja az információkat, hogy az az összes ismert internális memória szabályszerüségével rendelkezik. Pl. jobban emlékszik az először és utoljára rátöltött adatokra, mint a köztük lévőkre, vagy összekeveri a Harang és a Csengő utca címeket. Ez esetben az externális folyamatok szabályszerüségei megegyeznek az agy folyamatainak szabályszerüségeivel, azok mégis externálisan vannak tárolva. Ilyen adathordozó eszköz nem létezik, de elvileg lehetséges. A kritikusok az ilyen hipotetikus eszközök miatt mondhatják azt, hogy lehetséges az elme kiterjedése, csak épp nem aktuális, vagy nem olyan gyakori, mint ahogy Clark és Chalmers sejteti (Weiskopf 2008). Csakhogy az egyes emberek kognitív folyamatai között is lehetnek különbségek a szabályszerüségek tekintetében anélkül, hogy bármelyiktől megvonnánk a kognitív státuszt, így meglátásom szerint az externális elemeknél is el kell fogadnunk ezek lehetőségét.

De amint azt korábban is láttuk, e különbségek nem számítanak különösebben: sőt, éppen a különbségek azok, melyek igazán hasznossá tehetik e kiterjedő, externális elemeket is involváló kognitív rendszereket. Ha épp olyanok lennének, mint az internális rendszer, akkor nem is lenne rájuk szükség. Otto esetében éppenséggel igen, hiszen ő hátránnyal indul, de az augmentációk nem csak valamifajta hiány pótlásáról szólhatnak, hanem a „,normális” javításáról is, vagy akár korábban nem létező képességről is. Erről bővebben később, a „Második hullám” fejezetben ejtünk szót, amikor a paritási elvre fókuszáló „első hullámtól” eltávolodunk és a komplementaritásra fogunk fígyelni.

\subsubsection{Természetes, pszichológiai és tudományos fajták}

Az internális és externális folyamatok közti különbségek nem csak azért problémásak némely kritikusok szerint, mert így nem teljesül a paritás elvében megfogalmazott, illetve egy adott értelmezéséből kiolvasható izomorfia: hanem azért, mert ez azt jelzi, hogy ezek a folyamatok külön fajtába sorolandók. Amennyiben a természetet az „ízületeinél” akarjuk megragadni (Adams és Aizawa 2001, p. 51), az internális és externális folyamatok külön való 
kezelése célravezetőbb, hiszen a hasonló működésmód, ismétlődő szabályszerüségek stb. ezeket szinte kijelölik. Ezen megfontolásokból mondja Adams és Aizawa, hogy: „a kogníciót az amögött meghúzódó kauzális folyamatok alapján kell meghatározni” (Adams és Aizawa 2001, p. 52).

Azon szabályszerüségek és törvények, melyek az intrakraniális folyamatokra érvényesek, egyszerűen nem érvényesek az azon kívül eső folyamatokra, ezért:

„a kiterjedt „memória” állapotok (folyamatok) externális részei annyira különböznek az internális memóriától (az emlékezés folyamatától), hogy különálló fajtaként kellene őket kezelni” (Rupert 2004, p. 407).

A kritikusok aggálya az, hogy mivel az internális és externális folyamatok különbözö természetes fajták, ezért nem lehetséges olyan tudomány, amely egységes keretrendszerben és módszertannal képes vizsgálni ezen hibrid rendszereket. Gondoljunk a sok memóriaaugmentációs eszközünkre a fizikai fotóalbumoktól kezdve az okostelefonon, laptopon, jegyzetfüzeten át az emailekig vagy akár a tetoválásokig bármire. ${ }^{45}$

„Mennyi az esélye annak, hogy vannak olyan érdekes szabályszerüségek, melyek jellemzőek az emberek interakcióira mindezen dolgokkal? A mi spekulációnk szerint kevés vagy semmi” (Adams és Aizawa 2001, p. 61).

Továbbá:

„transzkraniális (kiterjedt) folyamatokból valószínúleg nem emelkednek ki érdekes tudományos szabályszerüségek. Nincsenek törvények, melyek az emberekre és eszközhasználatukra lennének érvényesek az interkraniális (belső) emberi kogníció és a fizikai eszközök törvényein túl és azok fölött" (ibid.).

Clark arra hívja fel a fígyelmet, hogy nem biztos, hogy bölcs dolog elhamarkodottan ítélkezni szembeötlő felszíni különbségek alapján (Clark 2010, p. 50). Bármily különböző is Inga és Otto memóriája, lehetséges olyan szintű leírás, mely egységes keretben kezeli őket, pl. mint az információ-tárolás, -alakítás és -előhívás szempontjából.

Vegyünk egy olyan példát, amelyet Clark maga nem említ, amely által azonban egységes keretben kezelhetőek a fizikai szinten nagyon is különböző elemek és folyamatok: a

\footnotetext{
${ }^{45}$ A Clark által is emlegetett Memento címủ film amnéziás főhőse épp tetoválásokkal próbálja emlékeztetni magát arra, hogyan áll a nyomozásával.
} 
hálózatokat. A hálózatok új tudományának forradalma alapvető matematikai törvényszerüségeket tár fel olyan különböző rendszerek müködésében, mint amilyen a sejt, az internet, a gazdaság, az infrastruktúra vagy egy terrorista szervezet (Barabási 2003). Adams és Aizawa „karosszékből” való spekulációja aligha adott volna sok esélyt annak, hogy a fentebbi területeket összekötik bizonyos törvényszerüségek, vagy „érdekes” tudományos kutatás kiindulópontjául szolgálhatnak. Mégis azt látjuk, hogy az implementáció módja irreleváns e rendszerekben müködésük bizonyos jellegzetességeit tekintve.

Továbbá, ahogy Clark is megjegyzi, egy egységes tudományos keret létrehozása épphogy a tudomány feladata (Clark 2010, p. 50). Senki nem gondolja, hogy a számítógépek és az emberi agy ugyanúgy müködnének: ellenben az ténykérdés, hogy vannak-e olyan tudományok, melyek olyan ezek közti interface-ek és egy olyan egységes tudományos keret kialakításán dolgoznak, melyekben e két különböző rendszer egységesen kezelhető. Márpedig vannak ilyen tudományok (pl. Norman 1999, Rogers és mtsai. 2002).

Clark (Prinz javaslatára) egy másik, nagyon érdekes stratégiát is felvillant ezen (szerintem gyenge lábakon álló) ellenvetés hatástalanítására, amiből nyilvánvalóan kitünik, hogy a kiterjedt elme hipotézis milyen értékes lehet mint kritikai eszköz, még ha el is vetjük mint konstruktív elméletet. A fenti ellenvetés szerint a különböző természetes fajták nehezen vagy egyáltalán nem kezelhetők együtt. Érdemes lehet felvetni viszont egy talán még provokatívabb ötletet: hogy az elme maga sem egységes eléggé. Clark és Prinz a következőt írja ${ }^{46}$ :

„magának az „elme” fogalmának sincs egységes, koherens használata különböző filozófiai és tudományos projektekben, melyek állításuk szerint mind a mentális aspektusait vizsgálják" (Clark 2010, p. 63).

„nem elég, hogy nem elérhető kielégítő definíció, még hasznos, közös tudományos egyetértés, vezető prototípus, vagy kiugró tulajdonságok és vonások lazán kapcsolódó hálója sincs... nincs jele annak, hogy egy bármilyen természetes fajtával lenne dolgunk... sem annak, hogy... bármi mással, akármilyen homályos legyen is, amely ennek ellenére képes lenne legitimálni az elmét mint a tudományos kutatás rendes tárgyát" (ibid.).

Lehetséges, hogy a kiterjedt elme nem más, mint reductio ad absurdum, amely magának az elmének a fogalmát mutatja fel értelmetlenként? Onnantól kezdve, hogy nem

\footnotetext{
${ }^{46}$ A közös tanulmány végül nem jelent meg, Clark viszont idéz belőle.
} 
csak a tudatos tapasztalatok, emlékek, hitek számítanak kognitívnak, mentálisnak, vagy bármilyen értelemben az elme részének, hirtelen nincs kapaszkodó, hogy valójában $m i$ is az elme, azon túl, hogy (feltehetően) a fejen belül zajlik. Azonban ez a megközelítés is problémás, mint ahogy ebben a fejezetben ez remélhetőleg alátámasztást nyert. Adams és Aizawa ellenvetése látszik itt visszhangozni, miszerint a zavart a kognitivitás meghatározásának hiánya szüli. Csakhogy mi van akkor, ha nincs is olyan természetes fajta, amelyet „elme” néven ragadhatnánk meg?

Clark maga mindezek ellenére ragaszkodik az „elme” fogalmához, bármit takarjon is, és a kiterjedt elme hipotézist továbbra sem reductionak, hanem illusztrációnak tartja az elme nyitottságát illetően. Az elmét illetően tehát revizionista, nem pedig eliminativista.

A dolgozat „hivatalos” álláspontja szintén revizionista (tehát az „elme” fogalmának van szubsztantív tartalma), ugyanakkor szükségét érzem annak, hogy ezzel az állásponttal kapcsolatos bizonytalanságomnak is hangot adjak. Az „elme” Descartes idejében a tudatos vagy tudatosítható folyamatokat takarta; ez átalakult, amikor a tudattalan folyamatok is bekerültek a tudományos gondolkodás homlokterébe, de ez az elme még mindig az ember elméje. Darwinnal viszont az ember és többi állat közti éles határvonal is eltűnik. Az evolúció elméletének eredményeképpen az állatvilág (szinte?) egészére használhatóvá válik az elme fogalma, legalábbis ennek fokozatos jellege megvilágítást nyer, és komplexitási kérdéssé válik. Egy csimpánz elméjéről még szokás beszélni, egy polipé már nehézkesebb, és az élet fájának azon szintjén, ahol megjelenik valamilyen kezdetleges idegrendszer, pedig teljesen elbizonytalanodunk. De pl. a kognitív biológia néven futó interdiszciplináris tudományos vállalkozás azzal az előfeltevéssel vizsgálódik, hogy az egysejtủektől kezdve minden organizmus folytat kogníciót, amennyiben érzékel stimulusokat a környezetéből, és ennek megfelelően alakítja a viselkedését. Mégis bizonytalanul használjuk az elme fogalmát, de még a „kogníciót” is kevésbé komplex lényekre. De tulajdonképpen miért? Nem azért vajon, mert a fogalomban még mindig ott él hordalékként a karteziánus jelentés? Akárhogy is, a számítógépek, mesterséges algoritmusok azok, amelyek még mindig kívül esnek az „elme” köréből: egy számítógépnek nincsen elméje.

Itt lehet talán feltenni azt a kérdést, hogy amennyiben találkoznánk egy intelligens földönkívüli faj egyedével, aminek a biológiai agya pont olyan algoritmusok mentén müködik, amilyeneket az egyik számítógépünk is futtat, akkor mi alapján fogjuk azt mondani, hogy a földönkívülinek van elméje, a számítógépnek pedig nincs? Valószínűleg az alapján, hogy az egyik biológiai alapú; csakhogy ez egy egyszerű biosovinisztikus elöítélet, amelyet a funkcionalizmus eredményesen felszámol. Valójában azt kellene mondanunk, hogy a 
számítógépnek is van elméje. Ha pedig ennyi mindennek van elméje, akkor az „elme” valóban nem sok mindent jelent, és meglehet, hogy érdemesebb lenne úgy, ahogy van, elhagyni.

Ennek ellenére a kiterjedt elme hipotézist nem pusztán egy reductio érvként próbálom érteni, még akkor sem, ha mostanra bebizonyosodott, hogy szigorú értelemben nem feltétlenül van értelme sem a „,kiterjedt”, sem pedig az „elme” fogalmának. Mindenesetre ha így is lenne, és e fogalmak csak mint rövidítések vagy metaforák lennének értelmesek, a hipotézis akkor is méltó a vizsgálódásra, ugyanis arra hívja fel a fígyelmet, hogy az ember esetében azon neurális folyamatok összessége, amelyek együttesét „elmének” szoktuk hívni, milyen szorosan összefügg olyan folyamatokkal is, melyek nem neurális alapúak: olyannyira, hogy ezeket érdemes teoretikusan egy rendszerként kezelni és ugyanígy vizsgálni empirikusan.

\subsubsection{A „kapcsolat-konstitúciós hiba" hiba}

Adams és Aizawa (2001, 2008, 2010) - jobb szó híján - érdekes stratégiát választ a kiterjedt elme hipotézisének aláásásához. Egyik példájuk a hipotézis abszurditásának érzékeltetésére:

„Kérdés: miért gondolta a ceruza, hogy $2+2=4$ ?

Clark válasza: mert a matematikushoz volt kapcsolódva” (Adams és Aizawa, 2010, p. 67).

Ez a gunyoros két sor, mely a szerzőpáros szerint látványosan szemlélteti, hogy mi a baj a kiterjedt elme hipotézissel, viszonylag jól összefoglalja, hogy mi a baj a szerzőpáros kiterjedt elme hipotézisről alkotott képével (nem is szólva a matematikusokról alkotott képükről).

Értelmezésük szerint: „Clark láthatóan azt gondolja, hogy egy ceruza, Rolodex, számítógép, mobiltelefon, egy damil, vagy bármi internális folyamatai természetének nincs köze ahhoz, hogy az adott dolog végrehajt-e kognitív folyamatot.” (uo.) Az ellenvetésüket pedig így fogalmazzák meg: „Amikor Clark kognitívvá tesz egy tárgyat, amikor az egy kognitív ágenshez kapcsolódik, a kapcsolat-konstitúciós hibát (coupling-constitution fallacy) követi el" (uo.).

Szerintük ez a leggyakoribb hiba, amit a kiterjedt elme védelmezői elkövetnek. A lényege a hibának az, hogy egy kauzális viszonyból tévesen következtetnek a konstitúciós 
viszonyra. Tehát egy kognitív ágens hiába áll - tetszőleges komplexitású - kauzális kapcsolatban egy externális elemmel, ez nem jelenti azt, hogy az az externális elem akárcsak részben is konstituálná az ágens kognícióját. Saját szavaikkal: „a tény, hogy X tárgy vagy folyamat kapcsolódik Y tárgyhoz vagy folyamathoz, nem jelenti, hogy X része Y-nak” (ibid. p. 68).

Ez elsőre bármily jogos kitételnek tünik is, a probléma az értelmezésükkel világossá válik, amikor így fogalmaznak:

„Ha egy zsebedben lévő notesszel vagy összekapcsolódva abban az értelemben, hogy mindig kéznél van, sokat használod, megbízol benne stb., akkor Clark ebből arra következtet, hogy a zsebnotesz konstituálja a memóriád egy részét. Ha egy köhöz kapcsolódsz abban az értelemben, hogy mindig kéznél van, sokat használod, megbizol benne stb., akkor Clark ebböl arra következtet, hogy a kö konstituálja a memóriád egy részét” (2010, p. 67. Kiemelés tölem.).

A kő példának láthatóan nincs értelme, hiszen nem lehet úgy használni, ahogy a noteszt, tehát az a fajta kapcsolat, melyet Clark és Chalmers tart szükségesnek a kognitív összekapcsolódáshoz, nem is teljesülhet. Nehéz elképzelni, hogy egy kő és az agy együtt miként irányítaná a viselkedést oly módon, mint egy notesz és az agy együtt: de ha nem kőről, hanem pl. a Vygotsky (1978) ${ }^{47}$ által is vizsgált fonalakról lenne szó, melyekre csomókat kötnek használói, hogy emlékeztessék magukat különböző dolgokra, akkor már egy ilyen példa sem volna annyira idegen. Ebből is látszik, hogy Clark és Chalmers szerint a használat módja az, ami miatt egy kognitív rendszer konstitutív részét képezheti externális elem: szó sincs arról, hogy bármi önmagában kognitívnak számítana.

Adams és Aizawa gondolatmenetét a visszájára is lehet fordítani. Vajon önmagában mennyi kogníciót végez egy neuron? Clark a szerzőpáros nyomán írja:

„Kérdés: Miért gondolta a V4 neuron, hogy spirális minta van az ingerben?

Válasz: Mert a majomhoz volt kapcsolódva"

(Clark 2010b, p. 83).

\footnotetext{
${ }^{47}$ Rowlands $2010 \mathrm{~b}$ is felhozza ezt a példát.
} 
Nyilvánvaló, hogy nincs kogníció önmagában egy tollban; csakhogy önmagában egy neuronban sincs, de még neuroncsoportban sem: utóbbiakat azonban Adams és Aizawa örömmel fogja kognitívnak minősíteni, mégpedig azok sajátos természete miatt. ${ }^{48}$

Clark és Chalmers azonban nem az elemek természetére, hanem azok funkciójára fókuszál, amelyet a viselkedés irányításában vállalnak. A hangsúly számukra azon van, hogy egy externális elem miként kerül integrálásra egy kognitív rendszerben. Menary (2006) szerint a kognitív kapcsolódás két külön értelmezése vezet ahhoz a félreértéshez, mely egyfelöl Adams és Aizawa, valamint másfelöl a kiterjedt elme védelmezői közt jelentkezik.

„A: Aszimmetrikus kapcsolat: a környezet tulajdonságai kauzális befolyással bírnak a belső folyamatokra. Lehetséges, hogy megváltoztatjuk a külső környezetet, és az hat az alany kompetenciájára és viselkedésére. Ha elveszed tỏlem a naplómat, nem fogok emlékezni az összes tennivalómra. A napló segíti az emlékeim előhívását, de nincs szükség ennél tovább menni, és azt mondani, hogy mivel a naplónak kauzális hatása van rám, ezért része a memóriámnak vagy a kognitív folyamataimnak, melyek lehetővé teszik, hogy emlékezzek. Hiba lenne ezt állítani pusztán kauzális kapcsolat alapján.

B: Szimmetrikus kapcsolat: a belső és külső tulajdonságok kölcsönösen meghatározó kauzális hatással vannak egymásra, amely idővel kibontakozik. Nem arról van szó, hogy a napló egyszerủen segíti vagy okozza mint input a különböző kognitív folyamatok lezajlását az agyamban; inkább a naplóból való információ előhívás externális folyamata és az ezalatt megjelenő folyamatok az agyamban közösen irányítják jövőbeli viselkedésemet” (Menary 2006, p. 335).

Clark és Chalmers B értelemben használja a kognitív összekapcsolódást: számukra az externális elem éppoly fontos kauzális szerepet játszik, mint az internális. Csakhogy meglátásom szerint nem ez az egyet nem értés oka. Adams és Aizawa B-re is azt mondanák, hogy ez pusztán kauzális viszony, bármily összetett is, és épp ezért vádolják a kiterjedt elme védelmezöit a kapcsolat-konstitúciós hiba elkövetésével.

A probléma ezzel a kapcsolat-konstitúciós hiba érvvel az, hogy éppen az a kérdés, hogy kauzális viszonyokat, amennyiben megfelelő módon állnak fenn (lásd Clark és Chalmers kritériumai), tekinthetünk-e konstitutívnak? Clark és Chalmers amellett érvel, hogy érdemes externális folyamatokat a kognitív rendszer konstitutív részének tekinteni, mert ez a keret jobban megragadja a kogníció lényegét. Erre azt válaszolni, hogy a kauzális viszony konsitutívnak tételezése egy érvelési hiba, inkább tủnik érvelési hibának, mégpedig a

\footnotetext{
${ }^{48} \mathrm{Az}$ ezzel kapcsolatos problémákra és kérdésekre a „Kogníció jele” alfejezetben térünk ki részletesen.
} 
bizonyítandó előfeltételezésének. Amikor amellett érvelnek, hogy pl. externális és internális elemek annyira különbözök, hogy nem tartozhatnak ugyanazon pszichológiai fajtához, az amellett érv, hogy nem érdemes externális elemeket konstitutívnak tekinteni, mert akkor rossz helyen próbáljuk „felszeletelni a természetet”: ekkor nem esnek az érvelési hiba csapdájába, de a „kapcsolat-konstitúciós hiba” során meglehetősen úgy tűnik, hogy igen. Mindenesetre itt az ideje jobban körüljárni, mit is jelent a konstitúció és a kauzalitás.

\subsubsection{Konstitúció és kauzalitás}

A kiterjedt elme koncepciója annak propagálói és ellenzői szerint is konstitutív tézis, többek között ezért képes olyan heves érzelmeket kiváltani. Pl. Rowlands így írja: „A kiterjedt elme tézise (...) (néhány) mentális folyamat kompozíciójáról vagy konstitúciójáról való állítás. A kompozíció egy meglehetősen különböző viszony a dependenciától (függőségtől)” (Rowlands 2010b, p. 60). Épp a konstitutív jellege adja a kiterjedt elme metafizikai súlyát, és ez különbözteti meg az embedded mind tézisétől, amely még nem jelent teljes szakítást a karteziánus elmeképpel. Rowlands így különbözteti meg a kettőt:

„[az embedded mind] szerint némely mentális folyamatok úgy funkcionálnak, sőt, úgy vannak megalkotva, hogy bizonyos környezeti struktúrákkal együtt funkcionáljanak: így tehát az utóbbiak hiányában az előbbiek nem tudják azt tenni, amire hivatottak, vagy nem tudnak úgy müködni, ahogy kellene. Tehát néhány mentális folyamat függ, és talán lényegileg függ működésében a tágabb környezetétől. A kiterjedt elme ellenben nem csak egyszerúen azt állítja, hogy mentális folyamatok ily módon szituáltak állványzatok [scaffolding] egy tágabb rendszerében, egy olyan rendszerben, amely segíti, talán nélkülözhetetlen módokon segíti ezen folyamatok operációit. Ez egy függőségi állítás lenne. Inkább azt állítja, hogy az, amit teszünk ezen állványzatok tágabb rendszerével részben (....) konstituálja mentális folyamatainkat" (Rowlands 2010b, p. 61).

Menary is hasonlóan fogalmaz:

„Egyszerü externális faktoroktól való kauzális függés - még akkor is, ha a függés abból a fajtából való, amely „szükséges” [értsd: a funkció adekvát ellátásához] - egyszerűen nem elegendő a genuin kognitív kiterjedéshez. Amire szükség van, az a mentális konstitutív függése externális faktoroktól (...) Csak ez az utóbbi fajta kiterjedés - nevezzük ontológiai kiterjedésnek - lesz megfelelö" (Menary 2007, p. 246). 
Ameddig csak - tetszőlegesen szoros - függőségi vagy kauzális viszonyban állnak internális és externális folyamatok, addig metafizikailag kevésbé egzotikus tézisről beszélünk (embedded mind), amelyet még olyan véres szájú kritikusok is elfogadnának, mint Adams és Aizawa. A vita a konstitúció miatt élesedik ki: látható, hogy ez különösen fontos kitétel a kiterjedt elme propagálói és kritikusai szemében is. Arról a kérdésről azonban kevesebben beszélnek, hogy ez mit is jelent. Mennyivel több, illetve miben más egy konstitutív viszony, mint egy kauzális ${ }^{49}$ A metafizikai gondolkodásban ennek a kérdésnek és különbségtételnek nagy hagyománya van (ahogy az ebben a vitában is világossá válik), de ha e hagyományon kívül is körülnézünk, biztos, hogy van értelmük? Valóban szokás folyamatok közt ilyen különbséget tenni, és ezt a különbséget tudományos szempontból lényegesnek gondolni, de ez egyáltalán nem biztos, hogy jogos. Ross és Ladyman szavaival:

„a vizet oxigén és hidrogén alkotja különböző polimerikus formákban, mint $\mathrm{H}_{2} \mathrm{O}_{2}, \mathrm{H}_{2} \mathrm{O}_{3}$ stb, amelyek folyamatosan formálódnak, eltünnek és újraformálódnak rövid időközönként oly módon, hogy létrehozzák a makroszkopikus vízfajta ismerős tulajdonságait. A szokásos filozófiai azonossági állítás «a víz $\mathrm{H}_{2} \mathrm{O}$ » fígyelmen kívül hagy egy gazdag és finom tudományos leírást, mely még mindig nem teljes. Ami fontos ebben a kontextusban, hogy a kauzáliskonstitúciós különbségtétel eltünik, mert a vízfajta egy emergens tulajdonsága egy komplex dinamikus rendszernek" (Ross és Ladyman 2001, p. 160).

Ross és Ladyman azt állítja, hogy a „konstitúció” metafizikai fogalmának legfeljebb metaforikusan van értelme, azonban semmiképp sem olyan viszonyrendszer, mely megtalálható lenne az „érett” tudományokban, például a fundementális fizikában. A világban nincsenek „kis dolgok”, amelyeket még kisebb dolgok konstituálnának, hanem komplex dinamikus rendszerek vannak végig a leírás minden elérhető szintjén. ${ }^{50}$

Ha ebből a szempontból vizsgáljuk Adams és Aizawa kapcsolat-konstitúciós hibáját, akkor könnyü hatástalanítani: a konstitúció fogalma egyszerủen csak metafora, amelyet nem lehet lefordítani semmilyen létező tudományos leírásra. „A modellezőknek ott kell és ott

\footnotetext{
${ }^{49}$ A következő idézet is ezt az észrevételt támasztja alá: ,,a pszichológia filozófiájában a magyarázatokat gyakran kauzálisként vagy konsitutívként kezelik, összhangban az előzetes határokat érintő feltevésekkel vagy intuíciókkal, melyek gyakran maguk sem rendelkeznek világos alapokkal és nem világítják meg a különbséget [kauzalitás és konstitúció közt]" (Hurley 2010, p. 106).

${ }^{50}$ Arról, hogy a „kauzalitás”, „konstitúciō” és egyéb központi metafizikai fogalmak hogyan emelkednek ki a nyelvünkbe ágyazott mély metaforákból, lásd Lakoff és Johnson 1980 és Lakoff 1987.
} 
fogják meghúzni a rendszerhatárokat, ahogy/ahol a legjobban tudják maximalizálni a helyi jelenségek hatékony megragadását” (Ross és Ladyman 2010, p. 156).

Nincs értelme annak, hogy a „kogníció a fejben van”, csakhogy ezek alapján annak sincs, hogy „a kogníció azon túl is van”. De vajon ezzel együtt nem párolog el a kiterjedt elme tézisének lényege is? Hiszen éppen $e z$ adja metafizikai súlyát.

A konstitúciós viszony nem empirikusan alátámasztható tény. Nincs, és nem is lesz olyan fejlett müszer, mellyel rá lehetne bukkanni, vagy rá lehetne mutatni, hogy ,itt ér véget az elme”. „Pusztán” kauzális viszonyok vannak, ezek között nincs minőségbeli különbség. Fogadjuk el, hogy ez csupán metafora. A kérdést az fogja eldönteni, hogy az internalista vagy kiterjedt modellek képesek-e hatékonyabban leírni és előrejelezni a kognitív jelenségeket, és ha a kiterjedt modellek bizonyulnak sikeresebbeknek, akkor lehet konstitutívnak beállítani a viszonyt, de csak egyszerüsítésként.

A dinamikus rendszerek eszköztárának segítségével ${ }^{51}$ matematikailag pontosan kiszámítható egy kognitív rendszer állapotainak egymáshoz képest való változása - és mivel az internális változások legalább annyira múlnak az externális elemek változásain, mint az internálisakon, ezért ez az eszköztár az organizmus határain oda-vissza átlépő kauzális hatásokat is legalább annyira számításba veszi, mint az internális változásokat. „Röviden, amíg az elme egy dinamikus rendszer, természetes azt gondolni, hogy kiterjed nem csak a testbe, de a világba is" (Robbins és Aydede, 2009, p. 8).

Egy ilyen modellben már nincs szó „konstitúcióról”, azonban az is világos, hogy közelebb áll a kiterjedt kogníció koncepciójához, mint az internalistához. Minden viszony kauzális viszony: ${ }^{52}$ ellenben vannak olyan kauzális hatások, amelyek nagyobb súllyal nyomnak a latban, mint a többi, és nagyobb mértékben alakítják át a rendszer müködését. Valójában rajtunk áll, hol jelöljük ki ezen „fontossági” határokat, hogy mely kauzális kölcsönhatások jelölnek ki tudományosan vizsgálható érdekes területeket. A kiterjedt elme, ha a konstitúciós tézisét zárójelbe tesszük, már valóban nem megkülönböztethető az embedded mind tézisétől: mégis jelentős, ugyanis a „konstitúció”, még ha ez csupán metaforának bizonyul is, indította el azt a jelentős vitát, amely még mindig tart és kognitív tudományos kutatásokat is motivál. A kiterjedt elme hipotézise a hozzá hasonló elméleteknél ${ }^{53}$ egyszerüen sikeresebben hívta fel a fígyelmet a központi idegrendszer és külvilág közti szoros interakciók

\footnotetext{
${ }^{51}$ Ehhez lásd: Beer, 1995; Thelen és Smith, 1994; van Gelder, 1995.

${ }^{52}$ Egyébként Ross és Ladyman a kauzalitás létét is megkérdőjelezik, legalábbis ahogy az a természetes nyelvi alapokon nyugvó gondolkodásunkban él. Ehhez bővebben lásd: Ladyman és Ross 2007.

${ }^{53}$ Clark és Chalmers aktív externalizmusa mellett beszélhetnénk még a következőkröl is: vehicle externalism Hurley 1998; Rowlands 2006, locational externalism Wilson 2004, és environmentalism Rowlands 1999.
} 
fontosságára, és arra, hogy ezek mennyire szorosak (lehetnek). Ilyen irányú kutatásokra és ilyen modellek létrehozására buzdít, melyek mindenképp árnyalják és bővítik a kognícióról alkotott hagyományos képet. ${ }^{54}$

Ugyanakkor, amennyiben valakinek mégis fontos a metafizikai konstitúció fogalma ebben a problémakörben, a kiterjedt elme externális folyamatai nem (vagy nem sokkal) nehezebben tekinthetők konstitutívnak a kognitív folyamatokban az internálisaknál - amint azt az ellenvetések itt felvonultatott sora is remélhetőleg bemutatja -, ezáltal pedig a kiterjedt elmének az a felfogása, amely magában foglalja a konstitutív tézist is, viszonylag védhetőnek bizonyul.

\subsubsection{A kogníció megkülönböztető jegye}

Adams és Aizawa $(2008,2010)$ szerint ahhoz, hogy eldöntsük, a kogníció kiterjed-e a külvilágba, előbb tudni kellene, hogy mit értünk kogníció alatt. Ez több mint érthető és jogos: ha el akarjuk dönteni, hogy van-e élet a Marson vagy egy vírusban (Shapiro 2009 példái), akkor reménytelen e probléma eldöntéséhez úgy nekikezdeni, hogy ne lennének kritériumaink annak eldöntésére, hogy mely jelenségek esetében beszélhetünk életről.

Ha a „kogníció” alatt pusztán információfeldolgozást értünk, akkor akár a DVDlejátszó is kognitív; ha pedig csak tudatos folyamatokat, akkor az agyban zajló folyamatok nagy része sem az (és az élőlények agyában zajlóak elsöprő többsége sem). Éppen ezért Adams és Aizawa a kogníció kritériumainak kidolgozására tesz kísérletet.

Szerintük ami kognitívvá tesz egy rendszert, az a rendszer folyamatainak természete: a neurális alapú folyamatok rendelkeznek $X$ tulajdonsággal, externális folyamatok pedig nem, tehát: csakis a neurális alapú folyamatok kognitívak. Ez a kogníció jele ellenvetés: a tollban nincsenek olyan természetü folyamatok, mint az agyban; tehát a toll nem kognitív. Sokszor érdekes stílusban megfogalmazott kritikájuk pozitív hozadékának azt lehet tekinteni, hogy felteszik, és igyekeznek megválaszolni is a kérdést, hogy tulajdonképpen mi is az X, tehát milyen természetű folyamatok zajlanak az agyban, másként: mi az, ami egy folyamatot kognitívvá tesz? Szerintük $e z$ a fontos kérdés, és Clark szemére vetik, hogy a kiterjedt elme tulajdonképpen csak elhalasztja e kérdés megválaszolását. Szerintük:

\footnotetext{
${ }^{54}$ A kiterjedt elme hipotézis metaforikus, heurisztikus felfogását propagálja pl. Sprevak 2009 is.
} 
„A kogníció első esszenciális feltétele az, hogy a kognitív állapotoknak nem-származtatott, intrinzikus tartalmakat kell involválnia” (2010, p. 48).

„...a kognitív állapotok a normális kognitív ágenseknél nem konvenciókból vagy szociális gyakorlatokból származtatják a jelentést" (uo.).

A kogníció folyamatai tehát olyan kauzális folyamatok, melyek nem-származtatott tartalmakat involválnak. Csakhogy Clark (2004 p. 10) szerint vannak olyan kétséget kizáróan kognitív folyamatok, amelyek származtatott jelentéseket tartalmaznak, azokkal dolgoznak, mint amilyen például a Venn-diagram köreinek egymást fedő része: ennek jelentése konvencióból származik, az ezt reprezentáló kognitív állapot tehát nem lehet tisztán intrinzikus. ${ }^{55}$ Clark válasza számomra meggyőzőnek tünik, de idézzünk fel néhány már korábban vizsgált példát is.

A modulok penetrábilitásának vizsgálatakor ${ }^{56}$ láttuk, hogy egy rendszer információsan nem elzárt a külső rendszerektől, és azt is láttuk, hogy nincs „tiszta” teóriamentes percepció a jelentéstulajdonítás minden szintjén jelen van az elmének, és ez sokszor (ha nem is általában) konvencionális jelentéseket jelent. Az intrinzikus jelentés további kritikáját pl. Wittgensteinnél is láthatjuk, ${ }^{57}$ nála ugyanis azokban semmi privát nincs, mind a közösségi gyakorlatból emelkednek ki. Továbbá a már említett Müller-Lyer illúzióra (és egyéb percepcionális illúziókra) vonatkozó eltérő mértékủ receptivitás is beszédes egyes törzseknél: pusztán intrinzikus tartalmakkal nehéz megmagyarázni egy ilyen kognitív különbséget.

Az ellenvetés további kritikájára később ${ }^{58}$ visszatérünk. Arra hívnám csupán még fel a fígyelmet, hogy ez a megközelítés esszencialista gondolkodást tükröz, mely eleve távol áll a kiterjedt elme funkcionalista alapjaitól, mely szerint a funkció, nem pedig a folyamat valamilyen aspektusból értett természete teszi lehetővé a kognitív jelenségek jobb megragadhatóságát.

További érdekesség, hogy Adams és Aizawa kontingens ténynek tartja, ${ }^{59}$ hogy az emberi kogníció ilyen (értsd: nem származtatott) tartalmakkal dolgozik. Csakhogy ezzel elvi

\footnotetext{
${ }^{55} \mathrm{Az}$,intrinzikusság” eleve nagyon problémás tulajdonság. Még egy olyan egyszerünek tünő eset, mint egy tárgy alakja sem biztos, hogy tisztán intrinzikus, hiszen meghatározhatják extrinzikus feltételek, például a téridőben elfoglalt helye. Lásd erről Marshall és Weatherson 2018.

${ }^{56}$ Lásd: „Előzmények, kontextus” fejezet.

${ }^{57}$ Lásd: 25. lábjegyzet.

58 A mentális megkülönböztető jegyének gyakran tartott nem-származtatott tartalmakról bővebben lesz szó, amikor az intencionális alapállással foglalkozunk az „Az intencionális alapállás nézőpontja” alfejezetben.

${ }^{59}$ Csakhogy, ahogy Shapiro (2009) joggal felteszi a kérdést: amennyiben Adams és Aizawa mentális tartalomelmélete nagyrészt nem empirikus tényeken alapul, továbbá a mentalitás jele ezen az elméleten múlik, akkor
} 
alapon zárják ki, hogy például számítógépek végezhetnének kogníciót, hiszen azok kizárólag származtatott tartalmakkal dolgoznak. Itt érezhetünk némi feszültséget. Nem lehetséges szilícium-alapú kogníció? Akkor sem, ha (szinte?) minden olyan dolgot jobban csinál, amit korábban kizárólag emberi képességnek gondoltunk? Például az AIVA (Artificial Intelligence Virtual Artist) projekt $^{60}$ mesterséges intelligenciája az ember alkotta zeneművektől megkülönböztethetetlen müveket képes komponálni, más mesterséges intelligenciák pedig legyőzik a világbajnok embereket sakkban és go-ban is. Ezek mind aktuális példák, még csak nem is néztünk a lehetséges világok vagy a tudományos-fantasztikum távlataiba. Hány korábban kizárólag emberinek tartott folyamatban kell jobbnak bizonyulniuk, hogy megkapják a „kognitív” státuszt? A tudatosság, fenomenális karakter az, amit nehéz a gépeknél elgondolni; ${ }^{61}$ csakhogy ha ezt tennénk meg a mentális megkülönböztető jegyének, azzal valószínủleg túl szükre szabnánk az elmét. ${ }^{62}$

\subsubsection{Kontroll helye ellenvetés}

Butler egy olyan ellenvetést fogalmaz meg, mely az internális és externális elemek közti viszony aszimmetriájában gyökerezik.

„Az nem lehet kérdés, hogy a komputációs és kognitív kontroll locusa az alany fejében található, és olyan módon tartalmaz internális folyamatokat, amelyek meglehetősen különböznek azon módoktól, miként az externális folyamatok érintettek. Amennyiben ez a tulajdonság valóban az igazán kognitív rendszer jegye, akkor ezen jegy alapján ki lehet zárni azon externális folyamatokat, melyekre Clark és Chalmers utal” (Butler 1998, p. 205).

Mivel a végső szó a mentális folyamatoké, ezért externális folyamatok nem lehetnek kognitívak, hiszen önmagában egyetlen externális folyamatban vagy elemben sem születhetnek döntések: így szerepük kevésbé lehet csak fontos, mint az internális folyamatoké; tehát e külső elemekben nem folyik kogníció. Ez az intuíció jogosnak tünhet, de

miért lenne kontingens empirikus tény, hogy a kogníció csakis idegrendszeren realizálódik? És mindez miért nem a bizonyítandó előfeltételezése? Ez a kérdés hasonlóképp felmerült korábban.

${ }^{60} \mathrm{https}: / /$ www.aiva.ai/

${ }_{61}$ Természetesen a mesterséges intelligencia egy külön probléma, melyre nem tudunk kitérni. Azt azonban megjegyezném, hogy ez az elvi kizárása az erős mesterséges intelligencia lehetőségének azért tünik furcsának, mert itt van az orrunk előtt genuin érzésekkel, gondolatokkal, fenomenális karakterrel egy lény, mely szintén végtelenül egyszerü automatákból épül fel - csak tükörbe kell néznünk.

${ }^{62}$ Ehhez lásd: “A dilemma: túl kicsi és túl nagy elmék” alfejezet. 
nem árt közelebbről is megvizsgálni. Az ellenvetés által felvetett probléma hasonló a tudatosság során felmerülöhöz, így a rá adható válasz is hasonló lesz. Butler gondolatmenete szerint úgy tünik, hogy minden folyamat, mely nem a kontroll végső lokusza, nem-kognitív folyamat. Csakhogy, ahogy arra Clark is felhivja a figyelmet (2010a p. 56) az elmében fóleg olyan folyamatok zajlanak, melyeknek nincs közük a döntéshozáshoz. Biztosan ennyire le akarjuk szükíteni az elmét? És mi van akkor, ha nincs is olyan helye az elmének, ahol a végső döntések születnek, ha nem létezik semmiféle központi döntéshozó, a „homunculus vezérlőközpontja" ${ }^{63}$ Amennyiben ez bizonyítást nyerne, Butler szerint vajon az következne ebből, hogy egyáltalán nincs elme? Vagy hasonlóképp, ha a kontroll (érzete) maga epifenomenálisnak vagy illuzórikusnak bizonyul, mint például Wegner (2002) gondolja, szintén erre az eredményre kellene jutnunk. Ez nem tűnik jó megoldásnak.

Ha létezik tudatos kontroll és annak vagy van valamilyen konkrét kitüntetett helye az agyban, vagy pedig ennél diffúzabb módon realizálódik (ahogy például a self sem lokalizálható konkrétan, mert az ezzel kapcsolatos reprezentációk használata során az egész agykéreg aktív (lásd: Gillihan és Farah 2005), és ezt tesszük meg tisztán kognitívnak, akkor sok egyéb folyamatot, sőt, feltehetően a legtöbb folyamatot, melyet szintén szeretnénk mentálisnak gondolni, ki kell zárnunk e körből. Így a mentális világ túl szükké válna. ${ }^{64} \mathrm{~A}$ kontroll helye tehát nem jelölheti ki a kogníció határait.

\subsubsection{Testi szituáltság és funkcionalizmus}

A kiterjedt elme funkcionalista hátterét nyíltan vállalják a szerzők: egy folyamatot nem a szubsztrátum vagy implementáció módja határoz meg, hanem a funkció, amelyet betölt. Könnyen látható ezen álláspont szubsztrátum-neutralitása. Ez akkor jelenthet problémát, ha egy olyan állásponttal együtt akarjuk elfogadni, mely éppen a mentális funkciók mély testi szituáltságát hangsúlyozza: az embodied mind tézissel (Shapiro 2004, Damasio 1994). A két álláspont közt egyes szerzők szerint feloldhatatlan a feszültség. ${ }^{65}$ Lehetséges stratégia, ha az embodied mind tézist a priori okok miatt implauzibilisnek mutatjuk fel, vagy pedig empirikus eredményekkel gyengítjük tarthatóságát; így a

\footnotetext{
${ }^{63}$ Ez nagyon is lehetséges, lásd erről az „Elfogadhatatlan én-kép” fejezetet és Dennett 2003.

${ }^{64}$ Arról, hogy ez miért jelent problémát, lásd "A dilemma: túl kicsi és túl nagy elmék" alfejezetet.

${ }^{65}$ Mások szerint pedig nem csak összeegyeztethetők, de össze is tartoznak. A szituáltságot hangsúlyozó elméletek éppen ezért sokszor egy, a 4E-nek nevezett kalap alatt kerülnek tárgyalásra (Enacted, Embedded, Embodied, Extended mind).
} 
kompatibilitás hiánya miatt nem sérül a kiterjedt elme hipotézis tarthatósága. Mi nem ezt az utat választjuk. Egy elméletnek eleve előnyére válik, ha kompatibilis más plauzibilis elméletekkel; nekünk pedig úgy tünik, az empirikus kutatások eredményei alátámasztani látszanak az embodied mind tézist (habár ez nem lezárt kérdés), így érdemesebb megszüntetni a kettő közti feszültséget. Először is lássuk, honnan ered az ellentét.

A funkcionalizmus első megfogalmazójának Putnam (1967)-et szokás tartani, aki a Neumann-gépet hozza példának, ami elnevezésével ellentétben nem fizikai gép, inkább algoritmus. A Neumann-gép épp olyan abban a tekintetben, mint a mai programok, hogy ugyanúgy futnak, bármilyen számítógépen futtatjuk is öket, tehát szubsztrátum-neutrálisak. A funkcionalizmus szerint a mentális folyamatok épp ilyenek ${ }^{66}$. A kérdés csupán annyi lesz, már ami a szubsztrátumot illeti, hogy képes-e oly módon szerveződni, hogy implementáljon adott mentális funkciókat. Amennyiben igen, a robotok szilícium-agya és ürlények számunkra idegen anyagból felépülő ,agya” mind-mind számot tarthatnak a kognitív státuszra:

„a tradicionális funkcionalizmus elvi alapot biztosít ahhoz, hogy olyan lényeket, melyek agya történetesen más fizikai dolgokból épül fel, mint a miénk, még mindig folytathassanak kogníciót. E jelentős eredményt úgy éri el, hogy a többszörös megvalósíthatóság sovinizmust felszámoló (értsd: neurális sovinizmus) tulajdonságát tulajdonítja az elmének” (Wheeler 2010, p. 248).

Ahogy a különbözőségi ellenvetéseknél már láttuk, az externális elemeket is magában foglaló folyamatok és tisztán internális folyamatok közti különbségek a kiterjedt elme szemüvegén át irrelevánsak, mégpedig azért, mert a durva funkcionális hasonlóság elegendő a kettő között. (Még pontosabban: a finomszemcsés különbségek nem számítanak, így tehát a liberális funkcionalizmus állaspontját veszi fel a sovinisztikusabbal szemben.) Ha jobban megvizsgáljuk, e funkcionalista nézőpontnak van egy további implikációja, mégpedig az, hogy az elme különválasztható szubsztrátumától, az ember esetében a testétől. Ez a különválaszthatósági tézis (seperability thesis) (Shapiro 2004), melyet már címében is remekül illusztrál Putnam Agyak a tartályban címü klasszikus tanulmánya vagy Dennett Where Am I? címủ szövege. Ez azért jelent problémát, mert az embodied mind egyik központi eleme, hogy épp ezt tagadja.

\footnotetext{
${ }^{66}$ A mottó: “Matter doesn't matter!"
} 
„az elmék alapjaikban tükrözik azon testek jellegzetességeit, melyek tartalmazzák őket (...) [ezért] gyakran lehetséges megjósolni a test tulajdonságait az elme tulajdonságairól való tudás alapján" (Shapiro 2004, p. 174).

„a pszichológiai folyamatok nem teljesek a test hozzájárulásai nélkül. A látás az emberi lények számára olyan folyamat, mely tartalmazza az emberi test tulajdonságait... A perceptuális folyamatok tartalmaznak testi struktúrákat és függenek azoktól. Ez azt jelenti, hogy a különböző perceptuális képességek leírása nem tarthatja fenn a test-neutralitást és azt is jelenti, hogy egy organizmus, amelynek nem emberi teste van, pszichológiai felépítésében nem emberi látással és hallással fog rendelkezni” (ibid. p. 190) (kiemelés tölem).

Nem vagyok benne biztos, hogy itt kibékíthetetlen ellentétről lenne szó. Shapirot úgy is lehet érteni, hogy emberi pszichológiai architektúrát nem lehet olyan szubsztrátumon implementálni, amely nem hasonlít kellőképpen az emberi testhez. Ha pontosan rekonstruálni akarjuk például azt egy nem emberi testen, ahogy az agy újraszervezi magát, akkor olyan szubsztrátumra lesz szükség, amely képes például az agy plaszticitását is utánozni. Sokkal finomabb részletekben kell hasonlítania a két szubsztrátumnak egymáshoz, hogy a funkciót elláthassa a nem emberi szubsztrátum is, ez való igaz, de az nem evidens, hogy elvi alapon mindezt miért ne láthatná el például valamilyen szilíciumalapú wetware. Ez még mindig megfér funkcionalizmus keretei között, csak épp szigorúbb (sovinisztikusabb). Mindez a kiterjedt elme főleg azon értelmezésével szemben jelent gondot, amelyik azt akarja mondatni az elmélettel, hogy az internális és kiterjedt folyamatok ugyanolyanok: például a notesz mondatai úgy hívhatók elő, mint Inga memóriájából az emlékek.

Itt érdemes kitérnünk a komplementaritásra, mely az eredeti szövegben kevesebb hangsúlyt kapott, de valójában az extended mind egyik legfontosabb eleme - legalábbis a kiterjedt elme második hullámának nevezett érv-sorozatban bizonyára, mely a komplementaritás és integráció fogalmai körül mozog (Wheeler 2010, Rowlands 2010b) ${ }^{67}$

Felejtsük el Ottot egy időre. Ö hátrányos helyzetből indul, hiszen Alzheimer-kóros, ezért igyekszik oly módon augmentálni memóriáját, hogy képes legyen úgy viselkedni, mint az egészséges emberek. Ugyanez a helyzet azokkal, akiknek hiányzik valamelyik végtagjuk: a protézisek egyre kevésbé ugyan, de még mindig távol állnak attól, hogy ugyanolyanok legyenek, mint az igaziak. De mi lenne, ha ahelyett, hogy arra fókuszálunk, mennyiben különbözőek ezek az externális elemek, és az ezek közti távolságot próbálnánk csökkenteni,

\footnotetext{
${ }^{67}$ Erről bővebben lesz szó a "Második hullám” fejezetben.
} 
inkább az ebben rejlő előnyökre fókuszálnánk? Vegyünk egy disszertáción dolgozó filozófust és jegyzeteit. A jegyzeteknek azon túl, hogy enyhítik a memóriára nehezedő nyomást, épp az a legnagyobb előnyük, hogy másmilyenek, mint a biológiai memória. A szó és gondolat elszáll (legalábbis a biológiai memória mindenféle törvényszerűségeinek alá van rendelve, így torzul, átalakul, eltünik), az írás megmarad: statikusan. A jegyzetek nem pótolják a filozófus kogníciójának hiányzó részét, hanem kiegészítik, megnövelik annak kapacitását. (Ráadásul milyen jelentős mértékben: próbált valaha bárki jegyzetek nélkül disszertációt írni?) Ha innen, a komplementaritás felől közelítünk, akkor nyilvánvaló, hogy az ilyen externális elemek nem azonosithatók internális folyamatokkal: és épp ebben rejlik az erejük. Ez azonban nem jelenti azt, hogy egy ilyen kiterjedt rendszer ne lehetne kognitív. Az externális elemekre ezért nyugodtan lehet a liberális funkcionalizmust alkalmazni, amennyiben pedig pontosan akarunk internális állapotokat reprodukálni, ott sovinisztikusabbat. ${ }^{68}$

Egyrészt egy olyan nem emberi szubsztrátum esetében, mely képes reprodukálni a megtestesülés pszichológiai architektúrájában is megjelenő vonásait, az elme igenis különválasztható lesz a konkrét testétől, tehát a különválaszthatósági tézis teljesülhet, ha kellően szigorú kikötésekkel élünk. Másrészt az emberi elme megtestesülése (amennyiben valóban az) kontingens ${ }^{69}$ tény. A kogníciónak egyáltalán nem kell szükségszerüen megtestesültnek lennie, ami abból is látszik, hogy elgondolható, hogy nem az - mint ahogy korábban erről így is volt szokás gondolkodni. Így, ha egy kiterjedt rendszernek van olyan része is, mely nem megtestesült és a liberális funkcionalizmus érvényes rá, valamint olyan is, amely megtestesült, és ezért a sovinisztikusabb funkcionalizmus jellemzi, ez még mindig képezhet egy kognitív rendszert. Ennélfogva a kiterjedt elme és megtestesült elme kompatibilis lehet egymással, tehát az ezek kibékíthetetlenségén alapuló ellenvetés nem biztos, hogy célt ér.

Az embodiment és különválaszthatósági tézis kibékítése valójában ennél komolyabb akadályokba is ütközhet, amennyiben az emóciókat is figyelembe vesszük. Erős érvek szólnak amellett ugyanis, hogy az emóciók (amilyen például a félelem vagy szexuális izgalom) nem többek, mint maguk a testi megnyilvánulások. A gondolatkísérlet, mely ide vezet, egyszerü: kezdjük el sorban elvenni a testi „kísérőit” például a félelemnek, amilyen a gyors légzés és szívverés, reszketés, izzadás, stb. Ha mindezt elvettük, mi marad, ami még emócióként lenne felismerhető? James (1884) szerint semmi. Tehát, szól az érv, az emóciók maguk a testi

\footnotetext{
${ }^{68}$ A komplementaritásról hosszabban beszélek a „Második hullám” fejezetben.

${ }^{69}$ Metafizikai értelemben kontingens. Evolúciós szempontból ez bizonyára nagy előnnyel járt (amennyiben valóban megtestesült), így gyengébb értelemben vett szükségszerüségről talán mégis lehet beszélni.
} 
reakciók összességei. Ez akkor jelent problémát, ha az emóciókat a kogníció részeinek tekintjük, vagy legalábbis releváns módon hatnak rá, befolyásolják azt: mégpedig azért, mert egy olyan test, amelyik nem ugyanúgy reprodukálja az emóciókat, mint az eredeti, egyszerủen más kognitív folyamatokat fog eredményezni. Illetve, ha test nélküli agyakat és pótagyakat gondolunk el, akkor meglehet, hogy az emóciók teljes mértékben hiányozni fognak (hiszen azok maguk a fiziológiai reakciók). Márpedig úgy néz ki, hogy emóció és kogníció különválasztása meglehetősen problémás.

Az emóciók megtestesülési vagy embodiment elméletét támasztják alá például azok a kísérletek, ahol vagy egy szájban tartott toll (Strack és mtsai., 1988) vagy pedig pusztán kimondott szavak $^{70}$ (Zajonc és mtsai., 1989) kényszerítették a szájat mosolygásra: még ezekben az esetekben is pozitívabban értékelték az alanyok azokat a dolgokat, amelyeket a kísérletvezetők eléjük tettek, pedig az arcukra ülő kifejezések teljesen tudattalanul jöttek létre. Úgy tűnik, az emóciók a morális ítéletekben is meglepő módon játszanak közre. Például alanyok szigorúbb morális ítéleteket alkotnak, ha a közvetlen környezetük undorító, például az asztal, aminél ülnek, ragacsos és tele van szeméttel.

Csakhogy ezek a kísérletek nem csupán az emóciók embodiment elméletét erősítik, hanem azt is, hogy az emóció és kogníció magasabb folyamatai nem különíthetőek el élesen egymástól. És ha ez valóban így van, akkor a különválaszthatósági tézis megvalósulása problémás, és így a funkcionalizmust is érinti a kihívás. Hiszen egy emóciók nélküli kogníció másfajta kogníció lenne. Egyáltalán nem biztos, hogy a kogníció képes lenne müködni emberi módon, például a morális ítéletalkotás során - amennyiben elfogadjuk az erkölcsi ítéletek szentimentalista megközelítését, miszerint ezek az érzésekben, emóciókban gyökereznek. De gondolhatunk azokra a Damasio (1994) által végzett kutatásokra is, amelyek agysérült betegeket vizsgáltak, és amelyek arra engednek következtetni, hogy emóciók nélkül még akár a legegyszerübb döntéseket is képtelenek lehetünk meghozni. Tehát el kell ismernünk, hogy komoly feszültség áll fenn a funkcionalizmusból következő különválaszthatósági tézis és az emóciók embodiment tézise között. A nehézség elismerése mellett a jelen dolgozatban kénytelenek vagyunk e kérdést nyitva hagyni, illetve zárójelezni, és folytatni a gondolatmenetet a kitüzött cél irányában.

Önmagában azonban arról nincs szó, hogy a kogníció szükségszerüen embodied lenne, csupán arról, hogy az emberi (és valószínüleg, en bloc, a biológiai) élet így fejlődött ki, ami

\footnotetext{
${ }^{70}$ Pontosabban nevek. Ugyanaz a történet szerepelt kétszer a kísérletben, csak a föszereplő neve volt a különbség. A Peter nevet csak úgy lehet kimondani, hogy a száj mosolyszerủen elnyílik, míg a Jürgen név kiejtése során lefele biggyed.
} 
empirikus, kontingens tény. Csupán a kogníció pontos reprodukciójához van szükség a sovinisztikus funkcionalitásra, kiterjedt kognitív rendszerek esetében teljesen megfelel a liberális igény is. Ha az én észlelési folyamataimat egy nem finomszemcsés értelemben hasonló rendszer vinné végbe (például emberi testem helyett valami szilícium-alapú), akkor, még ha az észlelésem esetleg nem is lenne szigorú értelemben véve „emberi” észlelés, ettől még bizonyára észlelési és kognitív folyamat maradna.

De szerencsére nem kell ilyen elvont szinten gondolkodnunk erről. Bach-y-Rita (1972) az érzékszervi helyettesítés (sensory substitution) lehetőségét ${ }^{71}$ bizonyító és hasznosító úttörő kísérleteiben létrehozott olyan ember-gép interfészeket, amelyek épp ennek a problémának az áttekintésében segíthetnek minket.

\subsubsection{1. Érzékszervi helyettesítés}

Ezekben az esetekben egy érzékszervi bemenet kerül kicserélésre vagy átstrukturálásra, amely ezáltal egy eredendően más érzékleti modalitás útvonalán juttatja el az agyba az információt; az agy (megfelelő régiója) pedig, alkalmazkodva a megváltozott körülményekhez, képes ezt az információt ahhoz hasonló módon - ha éppen nem identikusan - kezelni, mint ha az eredeti útvonalon érkezett volna. Az első példa során (Bach-y-Rita, 1972) mesterséges érzékelő (egy miniatür kamera) került összekapcsolásra veleszületetten vak emberekkel. A kamera által felvett vizuális információt a szerkezet rezgési vagy elektromos energiává alakítja át, és az alany bőrén elhelyezett továbbító segítségével a bőr ${ }^{72}$ receptorai mint taktilis információt továbbíthatnak az agynak, mégpedig szomatoszenzoros útvonalakon és struktúrákon keresztül (Bach-y-Rita és mtsai. 2003, p. 287). Az alanyok némi használat után arról számolnak be, hogy a képet a „térben”, három dimenzióban látják, és képesek a valóságnak megfelelő olyan perceptuális ítéleteket alkotni, amilyeneket a tipikus látásnak tulajdonítunk, ${ }^{73}$ amilyen például a perspektíva, mélység, szem-kéz koordináció. ${ }^{74}$

Mindez azért lehetséges, mert „nem a szemünkkel, hanem az agyunkkal látunk” (Bach-y-Rita 1972, p. 11), értve ez alatt azt, hogy „az agy perceptuális régiói számára lényegtelen, hogy az információ miként jut el a testbe, amíg olyan perceptuális szerv gyüjti

\footnotetext{
${ }^{71}$ Mely kísérletek egyben a neuroplaszticitás jelenségének feltárásában is úttörőnek bizonyultak.

${ }^{72}$ Illetve technikai okokból mostanában már inkább a nyelvre helyeznek elektrotaktilis beavatkozót.

${ }^{73}$ Olyannyira, hogy még vizuális illúzióknak is áldozatul esnek. Bach-y-Rita, 2002.

${ }^{74}$ Ebben az esetben pontosabban kamera-kéz koordináció.
} 
össze, amelyik fölött van motoros kontroll, és amíg olyan receptor-mátrix fogadja, amelyik képes kezelni annak részleteit” (Bach-y-Rita, 2002, p. 497).

Az alanyok beszámolnak azonban egy olyan jelentős különbségről, mely mellett nem mehetünk el szó nélkül, és amely (többek között) olajként szolgál azon vita tüzére, hogy vajon az ilyen érzékszervi helyettesítés segítségével látó emberek igazából látnak-e. Ezt a különbséget Bach-y-Rita a kválé hiányaként nevezi meg. Arról van szó, hogy az érzékszervi helyettesítés segítségével érzékelő alanyok hiába képesek felismerni és részletesen leírni például szeretteik arcát vagy épp egy Playboy magazinban lévő hölgy alakját, a kép mégsem hordoz számukra emocionális tartalmat. A megnevezés valójában nem túl szerencsés Bach-yRita részéről, hiszen kválé nem hiányzik, csupán az emocionális tartalom. Hiszen egy ilyen módon észlelő egyén számára is valamilyen „látni” a szerettei arcát; az élménynek van fenomenális karaktere, például kíséri az említett csalódottság, hogy a kép nem hordoz számukra emocionális üzenetet. Ennek a hiánynak a pontos okai kérdésesek, mindenesetre Bach-y-Rita lehetségesnek tartja, hogy az eszköz hosszabb használatával ez megváltozna, hiszen az olyan vakon született egyéneknél, akik egy mütét után kezdenek el látni, szintén hiányzik az emocionális tartalom az arcokat illetően. ${ }^{75} \mathrm{~A}$ vakon született gyerekek még elragadtatásuknak adják jelét, ha érzékszervi helyettesítés útján „látják” kedvenc játékukat; ez azt a reményt kelti, hogy az agy képes lehet rá, hogy az ilyen látás is hordozzon emocionális tartalmat; lehet ez gyakorlat kérdése, az időben elkezdett gyakorlat kérdése, illetve mélyebb okok is meghúzódhatnak a háttérben, mindenesetre a dolgozatnak nem feladata ezt megítélni.

A kérdésre, hogy ezekben az esetekben „igazi” látásról beszélhetünk-e, pontosabban hogy az SSD-t használó vak alanyok tapasztalata vizuális alapú érzékelés-e, a válaszok megoszlanak. Morgan (1977), Poirier és mtsai. (2007) és Renier és mtsai (2005) szerint igazi látásról beszélhetünk a szubsztitúciós esetekben, Gray (2003) és Block (2003) szerint pedig nem, nekünk azonban nem áll módunkban jobban elmerülni ebben a problémában, és a mi szempontunkból ez nem is kifejezetten fontos. ${ }^{76}$ A különbség a két látás között evidens, ugyanakkor a mi szempontunkból irreleváns: nincs szükség rá, hogy a két folyamat finomszemcsés izomorfiát mutasson, elegendő a liberálisabb izomorfia is. ${ }^{77}$

Hogy az ilyen jellegü paritás-keresés miért zárójelezhető (vagy zárójelezendő), azt azok az esetek képesek még inkább megvilágítani, amikor a helyettesítés helyett

\footnotetext{
${ }^{75}$ Gregory és Wallace, 1963.

${ }^{76}$ Valószínűleg egyébként annak a vak hegymászónak sem, aki ilyen eszköz segítségével mászta meg az Everestet, persze nem kizárt, hogy eleve nem foglalkoztatják filozófiai kérdések. Nicola Twilley, Seeing with Your Tongue, May 15, 2017, The New Yorker.

77 Lásd erről bövebben a különbözöségi illetve a funkcionalizmus és testi szituáltság ellenvetéseket az „Ellenvetések” fejezetben.
} 
augmentációról van szó, így nincs is olyan „eredeti” folyamat, melynek megpróbálhatjuk megfeleltetni az ilyen fajta érzékelést. Az amputált végtagok helyére tett protéziseken lévő érzékelők még helyettesítésnek minősülhetnek; hasonló a helyzet, ha például egy asztronauta kesztyüjére kívül helyezünk el ugyanilyen érzékelőket, holott valószínűleg már ez is inkább augmentáció jellegü; ellenben ott már hiába keresünk az érzékszervi protézisekkel lehetségessé váló érzékelésnek megfeleltethető internális folyamatot, ahol (akár radikálisan) újfajta érzékleti modalitások jelennek meg. Erre érdemes felhozni néhány példát, ha másért nem, a téma aktualitásának hangsúlyozása végett.

Hiperspektrális látás: olyan SSD, amely lehetővé teszi, hogy a használója a molekulák különböző fényvisszaverési tulajdonságai alapján megkülönböztessen vizuális alapon megkülönböztethetetlen kémiai anyagokat is (Alsberg 2012). Így az elektromágneses spektrum egyik emberi szemmel eddig láthatatlan tartománya válik érzékelhetővé.

Radar által felvett információt vibrotaktilis információvá alakító ruhaalapú SSD, amely pl. pilótákat tájékoztat a sebességről valós időben (Mann 2001).

Krueger (2007) olyan SSD-t mutat be, amely a mágneses mezők érzékelését teszi lehetővé, illetve a FeelSpace csapata a mágneses érzékelést hatékonyabb térbeli tájékozódáshoz alkalmazza (Nagel és mtsai. 2005).

Egy másik alkalmazás segítségével (Ultrasonic Intra-Body Communication) a testben elhelyezett (szív, gyomor, máj) müszerek jelzéseit lehet hallani, így az egyébként érzékelhetetlen, testünkben zajló és egészségünkkel kapcsolatos fiziológiai folyamatok lesznek lekövethetők (Daly 2016).

Bármennyire is újszerüek ezek a modalitások, az agy képesnek tünik rá, hogy integrálja és felhasználja az ily módon nyert információkat, akár már néhány órányi gyakorlás után is. Az agyat láthatóan nem érdekli az információ eredete: kérdés, hogy minket miért kellene? Persze meglehet, hogy amennyiben az észlelésnek nevezhető folyamatok spektruma ily mértékben kitágul, új nomenklatúrára lesz szükség, ha pontosabban akarjuk kategorizálni őket. Bach-y-Rita és mtsai. (2003 p. 286) javaslata szerint megkülönböztethetjük őket a következők mentén:

(a) az információ forrása (a szenzor vagy virtuális modell fajtája);

(b) melyik modalitáshoz kapcsolódik (vizuális, auditoriális, taktilis, stb.);

(c) az információ szerepe (helyettesítő vagy augmentatív).

A kiterjedt elme első két hulláma (c) mentén válik szét, csakhogy, amint láttuk, ennek a különválasztásnak abból a szempontból nincs jelentősége, hogy az adott folyamat kognitív 
vagy nem kognitív. Ahogy itt sincs: pontosíthatunk a különböző SSD-k megnevezésén a fenti dimenziók alapján, azon azonban ez mit sem változtat, hogy mindegyik esetben észlelési folyamatokról beszélünk.

\subsubsection{Kognitív felfúvódás, csúszós lejtő és a határtalan elme}

A kritikusok általában a paritást és az összekapcsolódást találják meg támadási felületként, erre azonban Clark és Chalmers által megadott „B” kritériumok esetében is van mód, ahogy azt Sprevak szellemes gondolatmenete is bizonyítja. Lássuk, hogy miért.

A funkcionalizmus egyik nagy elönye, hogy teret biztosít a többszörös megvalósíthatóság tézisének ${ }^{78}$, és ettől nem teljesen függetlenül egy meglehetősen erős intuíciónknak, melyet Sprevak (2009) marslakó-intuíciónak nevez. Ennek lényege, hogy

„... lehetséges, hogy egy lény mentális állapotokkal rendelkezzen akkor is, ha tölünk különböző fizikai és biológiai felépítéssel bír. Lehetséges, hogy egy intelligens organizmusnak „zöld trutyija” van neuronok helyett, és más fajta kapcsolatok vannak az „idegrendszerében”. A marslakó-intuíció érvényes a finomszemcsés pszichológiára és fiziológiára is: nincs oka, hogy egy marslakónak miért kellene pontosan olyan finomszemcsés pszichológiával rendelkeznie, mint nekünk. Egy marslakó fájdalomválasza a miénktől különbözőképp halhat el [decay]; a tanulási profilja és reakcióideje lehet, hogy nem egyezik a miénkkel; a mentális állapotai tipikus okai és hatásai eltérhetnek a miénktől; sőt, a tágabb funkcionális kapcsolatok a marslakó kognitív rendszerei közt (pl. a memória és percepció közt) is eltérhetnek” (Sprevak 2009, idézi Wheeler 2010, p. 261).

Ez az intuíció a következő módon válik számunkra érdekessé. Vegyünk egy biztosan kognitív rendszert, az egyszerüség kedvéért Ingát, valamint egy másik rendszert, aki a kognitív státuszért száll ringbe, pl. egy xenomorph-ot (ez az Alien címü film szörnyetegének neve, de az elnevezés szó szerinti jelentése miatt is találó). Ha azt mondjuk, hogy a két rendszernek a lehető legfinomabb részletekig egyezniük kell pszichológiai felépítésükben ahhoz, hogy utóbbi kognitívnak számíthasson (sovinisztikus funkcionalizmus), akkor csak Inga rendszere lesz kognitív, hiszen bizonyára lesznek eltérések (például a xenomorphnak nincs, vagy alig

\footnotetext{
78 A funkcionalizmus manapság az uralkodó álláspont a kortárs elmefilozófiában és kognitív tudományban (Tőzsér 2008, p. 57). Ennek többek között az is oka, hogy a többszörös megvalósíthatóságot lehetővé teszi.
} 
van fájdalomérzete). Ez sérti egyrészt a marslakó-intuíciót, ugyanakkor azért is problémás lehet, mert ilyen finomszemcsés eltérések emberek között is lehetnek, de mégsem gondolnánk, hogy ez a kognitív státusz megvonásával járna. Ha pedig azt mondjuk, hogy Inga és a xenomorph egyaránt kognitív, akkor a funkcionalizmusunkat kellőképp liberálisra enyhítettük, ez viszont a kiterjedt elmét hozza nehéz helyzetbe.

Megtehetjük ugyanis - érvel Sprevak -, hogy elgondolunk egy kiterjedt rendszert, amilyen például Otto és notesze, és egy ennek a kiterjedt rendszernek funkcionálisan megfelelő rendszert átviszünk az organizmus ,,zöld trutyijába”, tehát az organizmus (biológiai alapú) mentális apparátusának részeként gondoljuk el. Ez esetben a marslakó rendszere kognitívnak minősül. Erre a paritási elv alapján van módunk, e szerint ugyanis egy rendszer kognitív státuszát tekintve nem számít, hogy hol helyezkedik el, csakis a funkcionalitás (kellően liberálisan felfogott) izomorfiája. Csakhogy a paritási elv kétélü fegyver. Ha a marslakó másfajta kognitív folyamatainak funkcionálisan megfeleltethető rendszereit kiterjedt rendszerekként gondoljuk el, akkor olyan rendszereket is kaphatunk, melyek kognitív besorolásáról minden intuíciónk irtózni fog. A notesz esete intuitíve még viszonylag elfogadható, de azt is látnunk kell, hogy azért, mert Clark és Chalmers a „B” kritériumokat tekinti érvényesnek rá. Álljanak itt most ezek újra:

(B1) A notesz megbízhatóan elérhető és Otto rendszeresen használja.

(B2) Az információt, amit Otto a jegyzetfüzetben talál, többé-kevésbé automatikusan jóváhagyja, tehát igaznak fogadja el. (Nem úgy, mint például a pletykákat.)

(B3) A noteszban lévő információk könnyen hozzáférhetők, amikor csak Ottonak szüksége van rájuk.

(B4) A noteszban lévő információkat Otto valamikor a múltban tudatosan jóváhagyta, ennek következtében kerültek a noteszba.

De vajon mi alapján mondjuk, hogy e kritériumoknak érvényesülniük kell egy kiterjedt rendszer esetében? Hiszen ezek, amint arra mindjárt látunk példákat, nem érvényesek sok internális kognitív folyamatra: a paritási elv pedig az externális és internális folyamatok egyenlő elbírálását írja elő. Csakhogy a „B” kritériumokat elnézve láthatjuk, hogy tudunk olyan internális folyamatokat felmutatni, melyekre ezek egyszerüen nem igazak (Sprevak 2009, p. 514).

(B1) Vajon azért, mert egy internális folyamat nem megbízhatóan elérhető és nem realizálódik rendszeresen, vagy akár soha, attól már nem kognitív? Vegyük például az ihletet, vagy egy problémának (például tudományos, művészi, stb.) kiemelkedően kreatív 
megoldását: senki nem állítaná, hogy a kreativitás e váratlan megjelenése nem kognitív jelenség, csak mert nem müködik rendszeresen, vagy mert nem érhető el nehézség nélkül.

(B2) Egy kevés alkohol is elegendő ahhoz, hogy másnap elbizonytalanodjunk emlékeink megbízhatóságában; szélsőségesebb esetben az is elképzelhető, hogy valamilyen atipikus anatómia következtében valaki emlékezete általában meglehetősen bizonytalan, sokkal inkább, mint az átlagos emberé. Az információt egyik esetben sem hagyjuk jóvá kritika vagy ellenőrzés nélkül. Változtat-e mindez azon, hogy az ilyen ember fejében kognitív folyamatok zajlanak?

(B3) Gondoljunk egy tanulóra, aki a vizsgadrukk miatt nehezen idéz fel egy megtanult leckét, vagy egy olyan mélyen elfojtott hitre vagy vágyra, melynek előásásához pszichoterapeutára van szükség. Az, hogy az információ milyen könnyen vagy nehezen érhető el, egyik esetben sem releváns a kognitív státuszt illetően.

(B4) Clark és Chalmers szerint is problémás ez a kitétel, lehetséges ugyanis, hogy szert tehetünk hitekre, például nem tudatosuló érzékeléssel vagy pszichológiai heurisztikákkal. Szélsőségesebb esetben elgondolhatunk egy olyan marslakót, akinek innát ideái vannak; adott esetben olyanok is, amelyekről nem is tud, és soha nem hagyott jóvá.

Ezen kritériumok tehát nem jelölhetik ki a kognitív folyamatokat. Inkább ad hoc jellegüek, melyek célja, hogy a notesz esetét minél plauzibilisebbnek mutassák fel. És mivel az internális folyamatokra nem érvényesek, a paritási elv miatt az externális folyamatokra sem kell, hogy azok legyenek. Márpedig, ha ezek a korlátok nem érvényesek a kiterjedt rendszerekre, akkor olyan - a kiterjedt elme elveivel összhangban álló - rendszereket is elgondolhatunk, amelyek kognitívnak való besorolásától minden intuíciónk irtózik. Lássunk néhány példát.

Tegyük fel (Menary 2010c, p. 262), hogy van egy olyan program a laptopomon, amelyik kiszámolja, hogy a mától számított 5000 év múlva esedékes nap milyen dátumra esik a maja naptár szerint. Soha nem használom ezt a programot, adott esetben azt sem tudom, hogy van ilyen program a laptopomon. Most pedig képzeljünk el egy olyan marslakót, aki a biológiai kognitív apparátusával el tudja végezni ugyanezt a számolást, ugyanazon algoritmus segítségével. Lehet, hogy a marslakó soha nem számol ilyet; ez azonban nem jelenti azt, hogy amennyiben megtenné, a számára internális folyamat ne lenne kognitív. Az is lehet, hogy a marslakó nincs tudatában, hogy képes elvégezni ezt a számolást, de a megfelelő körülmények előhoznák belőle ezt a képességet; ugyanígy lehetséges, hogy a megfelelő körülmények soha nem állnak elő. Ennek megfelelően az összes program, mely megtalálható a laptopomon, akár tudok létezésükről, akár nem, a kognitív folyamataim részét képezi. És innen igazán csúszós a 
lejtő: mert ezek alapján a személyes könyvtáram, sőt, egy nyilvános könyvtár, az összes nyilvános könyvtár, vagy az internet információi szintén mind részét képezik hiteimnek, hiszen egyik kritériumot sem alkalmaznánk joggal az externális elemekre, ha az internálisakra nem érvényesek. Maga Clark is kiemeli:

"Kevés haszna lenne egy olyan elemzésnek, amelyik feltételezi, hogy tudom az összes tényt, mely fellelhető az Encyclopaedia Britannicaban, csak mert fizettem a havi részletet, és találtam neki helyet a garázsban" (Clark 1997, p. 217).

De nem ez következik vajon a kiterjedt elme végiggondolásából? Ha igen, az a kiterjedt elme, és általában a funkcionalizmus számára is komoly problémát jelenthet, hiszen a funkcionalizmusból következik a kiterjedt elme, ebből pedig, úgy tünik, következik a határtalan elme; az pedig a funkcionalizmus elvetésének szükségességét is magával vonja, ha következik belöle egy elfogadhatatlan elmélet (Sprevak 2009, p. 511). Két út áll elöttünk. Először is, megpróbálhatjuk hatástalanítani az ellenvetést, ezzel erősítve a kiterjedt elme pozícióját. Erre tesz kísérletet ez az alfejezet. Egy másik lehetőség, hogy a határtalan elmét kívánatos következményként mutatjuk fel, így emiatt nem sérül a kiterjedt elme, még ha következik is belőle. Erre a prima facie kontraintuitív következménynek más színben való feltüntetésére a disszertáció utolsó fejezetében teszünk kísérletet.

Több lehetőség is nyílik a csúszós lejtő elkerülésére. Rowlands (2010b) például úgy alakítja ki a kiterjedt elme egy saját verzióját, hogy kizárólag kognitív folyamatokról beszél, állapotokról nem: Otto esetében a noteszben lejegyzett információk diszpozicionális formájukban nem képezik Otto hiteit, vagyis nem mentális állapotok önnön jogukon. Ez az állítás ugyanis - Rowlands szerint - sem lenne védhető. De mégis beszélhetünk kognitív rendszerről Otto és a notesz esetében, mégpedig azért, mert a notesz manipulációját magában foglalja az emlékezés folyamata. Rowlands így fogalmaz:

„A kiterjedt elme tézise [értsd: ahogy ő érti] az, hogy némely kognitív folyamatok részben a kogitáló organizmus környezetében található információhordozó struktúrák manipulálásából, kihasználásából és/vagy transzformációjából állnak” (Rowlands 2010b, p. 59).

A kiterjedt elme ilyen értelmezése védettséget élvez attól a fajta csúszós lejtőtől, melyet a leggyakrabban hoznak fel ellene a szakirodalomban. Például a személyes könyvtáram, az internet vagy az Encyclopaedia Britannica nem képezik a hiteimet, legalábbis addig, míg nem 
kezdem el manipulálni, kihasználni és/vagy transzformálni ezeket az információhordozó struktúrákat. De még így sem lesz olyan könnyü a helyzet, ugyanis a csúszós lejtő más formában ugyan, de egy ilyen változatban is előáll: Rowlands (2010b) éppen ezért monográfiájának jelentős hányadát kénytelen az ellenvetés hatástalanításának szentelni.

Ugyanis ott vannak továbbra is a számítógépek, számológépek és egyebek a saját folyamataikkal, melyeket jó lenne kizárni a kognitív körből. Rowlands megoldása, hogy megszabja a kogníció kritériumait.

„F folyamat kognitív, amennyiben:

1. F tartalmaz információfeldolgozást - információhordozó struktúrák manipulációját és transzformációját.

2. Ezen információfeldolgozásnak rendes funkciója, hogy elérhetővé tesz a folyamatot megelőzően elérhetetlen információkat az alany vagy a folyamatot követő feldolgozó müvelet számára.

3. Ez az információ egy reprezentációs állapot létrehozásával válik elérhetővé $\mathrm{F}$ folyamat alanyában.

4. F folyamat hozzá tartozik ezen reprezentációs állapot alanyához”.

(ibid. p. 111) (kiemelés tölem).

A folyamat hozzátartozása egy alanyhoz, illetve az, hogy egy alany birtokolja (ownership) a folyamatot, képezi azt a tényezőt, amelyik megállítja Rowlands szerint a csúszós lejtő ellenvetést. A birtoklás fogalmának kifejtéséhez az intencionalitást mint világfeltárást elemzi, és Husserl, Sartre és Merlau-Ponty fejtegetéseit is igénybe veszi, így reménytelen vállalkozásnak tünik, hogy ezzel itt érdemben foglalkozzunk. Kénytelenek vagyunk megelégedni annyival, ahogy Rowlands értelmezéséből visszhangzik Merlau-Ponty híres vak emberének tapasztalata, amennyiben:

„Fenomenológiailag a vak ember tapasztalata nem szünik meg, mielött elérné a világot, mert (1) ez a tapasztalat intencionálisan irányul a világra (2) az intencionális irányultság feltáró vagy felfedő tevékenység, és (3) a feltáró tevékenység nem szünik meg, mielött elérné a világot. Tehát, amiatt, hogy a tárgy ott van a bot végénél, amiatt az ellenállás miatt, melyet a botnak biztosít, tapasztalja a vak ember a tárgyat mint térben elhelyezkedő dolgot a világban. A bot használatával a vak ember 
megszünik tapasztalni a botot. Mint feltáró tevékenység, a tapasztalata végigutazik a boton át egész a tárgyig magáig" (Rowlands, 2010b, p. 198). ${ }^{79}$

Az intencionalitás tehát keresztülhalad azon eszközökön, amelyeket a szubjektum a világfeltáró tevékenysége során használ. És így „a felfúvódás [értsd: csúszós lejtő] problémája aláásásra kerül azon tény által, hogy minden kogníciónak végső soron vissza kell kapcsolódnia az alany világfeltáró tevékenységéhez. Ahhoz, hogy egy folyamat kognitív lehessen, szerepet kell játszania abban, hogy kauzálisan feltárja a világot az alany számára" (ibid. p. 217).

Így például egy magára hagyott laptopon zajló folyamatok nem lesznek kognitívak, hiszen nem vesz részt semmilyen szubjektum világfeltárásában, hiányzik belőle az intencionalitás; ellenben könnyen kognitívvá válhat, amennyiben egy szubjektum használni kezdi.

Ez tehát Rowlands megoldása, melynek érdemi kritikáját helyhiány miatt kénytelenek vagyunk mellőzni. Mindenesetre az intencionalitás problémás voltára felhívnánk a figyelmet, és visszatérünk rá az utolsó fejezetben. Amennyiben azonban ez a megoldási irány nem tünik megfelelőnek, van más lehetőség is.

Térjünk vissza Sprevak dilemmájára. Egyrészt ott van a marslakó-intuíció, mely a kiterjedt elmétől függetlenül erős lábakon áll. Másrészt ott van a paritási elv, a kiterjedt elme egyik központi eleme (Sprevak szerint), amely lehetővé teszi, hogy olyan internális folyamatok kiterjedt hasonmásait gondoljuk el, amelyek a kognitivitásukat illetően kontraintuitív hibrid rendszereket eredményeznek.

Wheeler (2010, p. 264) ott véli felfedezni Sprevak érvelésében a hibát, hogy a marslakó-intuíciónak egy erősebb verzióját müködteti, mint ami indokolt lenne. Azt teszi ugyanis, hogy vesz egy kiterjedt rendszert, melynek externális elemét (illetve annak funkcionális megfelelőjét) behelyezi a marslakó „zöld trutyijába”. Ebben az esetben semmi más nem történt, mint hogy az adott elem térbeli helyzete, lokációja megváltozott: de ha a kiterjedt rendszer korábban nem volt kognitív, pusztán azért, mert a marslakó „fejébe” került, szintén nem kellene, hogy kognitív legyen. Hiszen a marslakó-intuíció annyit állít, ahogy a

\footnotetext{
${ }^{79}$ Merlau-Ponty e meglátása alátámasztást nyer többek között Paul Bach-y-Rita kutatásaiban is, akinek a kutatásairól az „Érzékszervi helyettesítés” címü alfejezet során esett szó. Itt elég a következő néhány sor: „Az érzékszervi helyettesítés egyszerü példája egy hosszú bottal tájékozódó vak ember, aki érzékel lépcsőt, járdaszegélyt, tócsát, de ezen perceptuális feladatok során nincs tudatában a kezében lévő semmilyen érzékletnek (melyben a biológiai érzékelők találhatók), vagy épp a karja és keze mozgásának, amely a botot tartja. Inkább a környezete elemeit érzékeli mint mentális képeket, melyeket a bot végéből eredő taktilis információból nyer" (Bach-y-Rita és mtsai. 2003 p. 286).
} 
fentebb idézett szövegrész is mutatja, hogy „lehetséges, hogy egy lény mentális állapotokkal rendelkezzen akkor is, ha tőlünk különböző fizikai és biológiai felépítéssel bír”. Azt azonban nem állítja, hogy bármi, ami egy marslakó „fejében” zajlik, pusztán emiatt a tény miatt, kognitív lenne. Wheeler szerint tehát Sprevak dilemmája feloldható abban az esetben, ha elvetjük a marslakó-intuíció ilyen erős fajtáját, így ugyanis nem lehetséges kigondolni internális folyamatokat olyan hibrid rendszerekként, amelyek kognitív státuszukat illetően konraintuitívek lennének.

Van, aki elfogadhatónak tartja ezt a választ. Csakhogy szerintem valójában a marslakó-intuíció wheeleri értelmezése túl gyenge: Sprevak nem pusztán azért tesz meg kognitívnak marslakói folyamatokat, mert a „fejben” mennek végbe. Hanem azért, mert az „idegrendszer” realizálja őket, tehát valamilyen módon integrálva vannak egy nagyobb rendszerbe. Így a maja naptáros program, mely a laptopomon futva nem tűnik kognitívnak, mégis csak kognitívnak fog tűnni a marslakó „,zöld trutyijában”. Ugyanis nem pusztán arról van szó, hogy van egy izolált alrendszer, melyben fut egy ilyen számítás; hanem arról, hogy az alrendszer által szolgáltatott információk adott esetben az organizmus viselkedését is meghatározzák, ahogy azt az ember idegrendszere is teszi. A marslakó-intuíciónak ezt is magában kell foglalnia; amennyiben mégsem, át kell alakítani.

Wheelernek (többekkel együtt) igaza van abban, hogy ami valójában hiányzik, az a kogníció egy olyan kritériumrendszere, amelyik mellőzi a lokációt: akkor könnyen eldönthetnénk egy folyamatról, hogy kognitív-e vagy sem, akár a „zöld trutyiban”, akár a dolgozószobánkban realizálódik. Valószínüleg ez a legnehezebb ellenvetés, melyet a kiterjedt elme védelmezőjének meg kell válaszolnia. Mindenesetre az nyilvánvalóvá válik, hogy a kognitív státusz eldöntését illetően bajban vagyunk, ha - némi egyszerüsítéssel élve - a „fej” kiindulópontot elveszítjük.

Hutchins (1995), aki némiképp máshonnan közelít a problémához, és akiről az „A globális elme felé" fejezetben lesz bővebben szó, a kogníció rendszerhatárait az információáramlás relatív sűrüsége alapján határozza meg. Így akár azt is lehet állítani, hogy azon mentális állapotok vagy folyamatok, amelyek nem állnak információs cserekapcsolatban az idegrendszerrel, valójában nem képezik annak részét. Így a maja naptáros program és egy valamilyen okból a többitől (nem feltétlenül fizikai értelemben) elszakadt agyrész egyaránt kikerül a mentálisból, ahogy a könyvtárak és az internet is, egészen addig, míg nem kezdem használni őket.

A fentiekben vázoltunk három lehetséges megoldást a kognitív felfúvódás dilemmájára. De ha egyik sem tünik elég meggyőzőnek, még mindig van egy lehetőség, 
mégpedig az, hogy bizonyos értelemben elfogadjuk az elme határtalan kiterjedését. Létezik olyan szempont, mely ezt a kontraintuitív következményt más, elfogadhatóbb fényben láttatja, de erre csak „A globális elme felé” fejezetben tudunk visszatérni.

\subsubsection{A cselekvések proliferációja}

Ami Clark és Chalmers externalizmusát aktívvá teszi a passzívval szemben, ${ }^{80}$ az externális elemek aktív szerepe a viselkedésgenerálásban és -szervezésben: az externális elem megváltoztatása a viselkedés változásával jár. A szerzők nagyrészt épp e szerep miatt tartják mentálisnak az externális elemeket. Gertler (2007) és Ambrus (2013) a következőt nehezményezi ezzel kapcsolatban.

Tegyük fel, hogy Otto hitek mellett vágyakat ${ }^{81}$ is tud tárolni egy olyan elektronikus eszközben, amelyik alkalmas lesz akciótervek létrehozására és egy humanoid (vagy akármilyen) robot irányítására, tehát az akcióterv végrehajtására is. Tegyük fel, hogy Otto azt rögzíti, hogy kedden egy bizonyos fajta édességet akar enni, melynek hozzávalóit adott helyen lehet beszerezni, illetve adott módon lehet elkészíteni. Otto azonban egész nap alszik kedden, miközben a robot beszerzi a hozzávalókat és elkészíti az édességet. A kérdés az lesz, hogy Otto csinálta-e az édességet. Clark és Chalmersnak erre feltehetően azt kell mondania, hogy igen, hiszen az ő mentális állapotai voltak a cselekedet kiindulópontjai, amelyeket externálisan tárolt. Látni kell, hogy a kiterjedt elme védelmezőinek azt kell állítaniuk, hogy Otto maga készítette el az édességet, miközben aludt. Hisz a robot része Ottonak: „Az a legjobb, ha Ottot kiterjedt rendszerként gondoljuk el, egy biológiai organizmus és externális források összekapcsolódásaként” (Clark és Chalmers, 2010, p. 39). Ahogy Gertler írja: „Minden bizonnyal Otto némely cselekedete közvetlenül csak az organikus részét érinti; tehát, a paritás alapján, meg kell engednünk azt is, hogy Otto némely cselekedete közvetlen módon csak a nem organikus részét érinti” (Gertler 2007, p. 197). Ez elfogadhatónak tünik. ${ }^{82}$ Csakhogy ebben az esetben lehetővé válik a cselekedetek proliferációja: ugyanis milyen elvi akadálya lesz annak, hogy Otto akár egy egész robothadsereget hozzon létre, mely robotok

\footnotetext{
${ }^{80}$ Ehhez lásd a 25-ös lábjegyzetet.

${ }^{81}$ Fenomenális karakter nélküli vágyra kell gondolni.

${ }^{82}$ Azt a látszólagos ellentmondást, hogy Otto egyszerre alszik és édességet készít, talán ki lehet békíteni. Ha én valamilyen agykontroll technikával, hipnózissal vagy hasonlóval elérem, hogy alvajárjak és közben pl. kávét csináljak, akkor ugyanez áll fenn: egyszerre alszom és kávét csinálok. De sok automatikussá vált cselekvés is hasonló lehet, amikor egy tevékenységre fókuszálok, de közben mást is csinálok. (Pl. autópályán vezetek, miközben veszekedek a párommal.)
} 
randalírozása szükségképpen mind Otto cselekedetei? Hangsúlyoznunk kell: Otto nem csak felelös a robotok viselkedéséért, hanem ő maga teszi mindazt, amit a robotok csinálnak (például becsengetnek házakba Texasban, hajóznak Kína felé, Rómában kávéznak, ${ }^{83}$ stb. egyidejüleg!) Az ellenvetés szerint ez roppant kontraintuitív. Ahogy Ambrus (2013) írja:

„A cselekedetek proliferációja azonban tarthatatlan, mert felszámolja az én fogalmát. Megengedi ugyanis, hogy egy partikuláris elme egyszerre sok helyen legyen, és sok (akár egymással ellentétes hatású) cselekedetet is végrehajtson. Ez nyilvánvalóan nem egyeztethető össze az én egységének feltevésével" (Ambrus 2013, p. 8).

Az én egységére kénytelenek leszünk máshol bővebben kitérni ${ }^{84}$, egyelöre foglalkozzunk az egyszerre több helyen levéssel és a néha egymással ellentétes hatású, meg általában véve túl sok cselekedettel. Mindez első ránézésre valóban rosszul néz ki a kiterjedt elme barátai számára, de talán mégsem olyan vészes a helyzet.

Én - aki nem rendelkezem olyan robotokkal, mint Otto - hány helyen vagyok most egyszerre és hány dolgot csinálok? A megszokott perspektívából tekintve természetesen egy helyen, és valamilyen értelemben egy dolgot csinálok, írom ezt a dolgozatot, habár tudattalanul közben lélegzek, ráncolom a szemöldökömet, megvakarom az orromat, szakkádikus szemmozgásokat végzek, pislogok, arra pedig nem emlékszem, hogy megsimogattam-e a macskám, amikor elment mellettem, de valószínüleg igen. De mi történik akkor, ha nem a megszokott perspektívából, egy másik skálán nézzük ugyanezt? Sejtszintről nézve vajon nincs óriási távolság két szervem között, amelyek egészen más dolgokat csinálnak, ráadásul sokszor mentális állapotok és folyamatok szabályozzák őket? Valójában a testemre is lehet azt mondani, hogy egyszerre sok helyen van és (szinte megszámlálhatatlanul) sok mindent csinál. ${ }^{85}$

Az „Otto robotjai” kép, amint mindenfelé randalíroznak, a leírás miatt tünik meggyőzőnek, de a kiterjedt rendszerek legfőbb rendezőelvéről megfeledkezik, mégpedig a funkcionális egységröl. Otto és a notesz egyetlen rendszert alkot, mert a viselkedést az

\footnotetext{
83 A robotok kávézhatnak Rómában vagy meditálhatnak Katmanduban, ugyanakkor ezeknek nem lesz fenomenális karaktere, minthogy ez nem is feltétele a kiterjedt rendszerek externális elemei számára. Nagyon limitált esetekben azonban még akár lehet is, ahogy Clark a teleprezencia megvalósulásait ecseteli nem tudományos-fantasztikus helyzetekben is (Clark, 2003). De az ilyen helyzetekben az alanynak kétirányú interakcióban kell állnia a távollévő externális elemmel, legyen az robotkéz vagy távirányítású kamera.

${ }^{84}$ Lásd az "Elfogadhatatlan én-kép" alfejezet.

${ }^{85} \mathrm{Az}$, hogy mit számítunk genuin cselekedetnek, természetesen befolyásolja ezt a képet: ehhez lásd: „Túl szük és túl nagy elmék" alfejezet.
} 
externális és internális elem együtt úgy szervezi, mint a kogníció általában. Otto el akar menni a múzeumba, és ezt a célt az internális és externális elem együtt éri el.

Ezt a funkcionális egységet is beleszőve a képbe, Ottot és a robothadseregét intuitíve sokkal elfogadhatóbb módon mutathatjuk be mint egyetlen kiterjedt rendszert - amivel akár a szuperhősfilmek proliferációját is a filozófia hasznára fordíthatjuk. A Vasember (lényegében Otto) egy robotruhában repül, lövöldözik és hőstetteket hajt végre, csakhogy van sok más robotruhája is, amelyek képesek automatikus módon (pontosabban egy központi mesterséges intelligencia és a Vasember közös irányításával) repülni és lövöldözni. Ha a Vasember a robotruha-seregével közösen végrehajt egy hőstettet, például egy kettévált hajót két oldalról összenyom, miközben középen összeforrasztja, akkor mit mondanánk, $k i$ tette ezt? Mondhatjuk, hogy a Vasember és a robotjai, de ez arra hasonlít, mint ha a kérdésre, hogy „ki ásta a gödröt a kertben?”, azt válaszolnám, hogy „én és az ásóm”. Egyébként a filmekben, ahol mindennapossá vált ez a sok robottestet egy célért irányító hős, úgy válaszolnak, hogy ,a Vasember", és ebben nincs semmi szokatlan a néző számára sem.

Egy másik példa: gondoljunk a hangyákra. Egy boly olyan funkcionális egységet mutat, hogy szuperorganizmusnak ${ }^{86}$ tekinthető „egy emlősnek sok testben” (Tautz, 2008, p. 3). A boly, ha két felekezetre szakad(na), és a felek háborúzni kezdenének egymással, onnantól kezdve nem egy szuperorganizmus lennének, hanem kettő; vagy, ha össze-vissza rohangálnának az individuális hangyák, akkor pedig nem lennének semmik és hamar meghalnának. Erre az utóbbi össze-vissza rohangálásra emlékeztet az ellenvetésben található Otto és robotjai kép. A hangyákat a funkcionális egység teszi szuperorganizmussá, és ezért lehet a Vasembert is önmagában egy szuperorganizmusnak gondolni, mely sok test révén, de ugyanazon célért dolgozik. És ez akár olyan szerteágazó tevékenységekben is megvalósulhat, mint hogy egyszerre sok helyre csönget be Texasban, hajózik Kína felé és kávézik Rómában csak épp az e dolgok mögött meghúzódó összefüggést adott esetben mi épp nem látjuk át: de kell lennie.

Az egymással ellentétes hatású cselekedetekre szintén azt mondhatjuk, hogy ezek mögött valójában egy adott célnak kell meghúzódnia. Például Otto egyik robotja tüzet rak, a másik meg oltja ugyanezt; ha Otto célja nem gőz előállítása (vagy valami hasonló), amennyiben nincs egy „magasabb cél”, funkcionális egység, akkor a rakoncátlankodó robot egyszerủen nem része Ottonak, hanem csak egy renegát, különálló robot.

\footnotetext{
${ }^{86}$ A szuperorganizmusokra hosszabban kitérünk a “Társas kiterjedt elme” fejezetben.
} 


\subsubsection{Elfogadhatatlan én-kép - A dividuum}

Sok ellenvetés - hol implicitebb, hol explicitebb módon - abban gyökerezik, hogy a kiterjedt elme egyfajta bizarr én-kép mellett kötelez el minket, mely, még ha nem is tagadja feltétlenül az én létezését, azt szétszórtnak, decentralizáltnak és összességében kontraintuitívnak mutatja fel. A kritikusok szerint egy ilyen én-fogalom elfogadhatatlan, tehát amennyiben a kiterjedt elméből egy ilyen én-fogalom következik, akkor az is elfogadhatatlan lesz. Ahogy Ambrus (2013) is írja, a kiterjedt elme „felszámolja az én fogalmát”, és „nem egyeztethető össze az én egységének feltevésével." Sok szerző foglal állást hasonló módon, és ez nyilvánvalóan olyan aggály, mellyel kezdeni kell valamit. Nem könnyíti meg a helyzetet, hogy a kiterjedt elme szakirodalmában nem igazán kerül tisztázásra az „én” és az elme viszonya, ezeket sokszor felcserélhetően kezelik őket a szerzők. E viszony megnyugtató tisztázása éppen ezért reménytelen vállalkozás egy ilyen terjedelmü alfejezet keretei között, mindenesetre egy irányvonal felvázolásával talán megelégedhetünk.

Az ellenérvre visszatérve: egyrészt lehetne azt mondani, hogy a kiterjedt elme valójában nem kötelez el minket semmilyen bizarr én-koncepció mellett, ez azonban valószínüleg nem igaz. De az ellenérv akkor sem müködik, ha - a kiterjedt elmétől függetlenül - az énről kiderül, hogy már eleve bizarr.

Az alábbiakban azt igyekszem bemutatni, hogy az erre apelláló ellenvetések egy egységesebb énképből táplálkoznak, mint ami tudományosan feltétlenül igazolható. És mivel nem csak érvelni áll szándékomban, de meggyőzni is szeretném az olvasót, több példát is hozok annak érdekében, hogy az intuíciókat kimozgassam a karteziánus buborékból.

Descartes episztemológiai nagytakarítása során az egot találja meg a bizonyos tudás fundamentumaként, mellyel kapcsolatban még a hipotetikus gonosz démon sem tudja megtéveszteni.

„az «én vagyok, én létezem» kijelentés - valahányszor kimondom, vagy elmémmel megragadom - szükségszerủen igaz” (Descartes 1994, p. 34).

Úgy tünik azonban, hogy a gonosz démon még egy utolsó megtévesztéssel élt és képes volt korrumpálni egy ilyen bizonyos belátást is. Valami szükségszerűen létezik; de hogy ennek „én” struktúrája lenne, az már erősen vitatható. Az ego transzparenciája, hogy az introspekció során azzal találkozunk, ami van mind olyan feltevés, mely nem alátámasztható, ráadásul 
tévútra vezethetnek. Fogalmazhatunk úgy, hogy a karteziánus démon él és köszöni, jól van: mostanra föleg saját kognitív belátásainkkal van elfoglalva.

Láttuk korábban, hogy Descartes szelleme miként él tovább a kognitív tudományokban, de a hétköznapi gondolkodást is legalább ennyire áthatja. Ezt alátámasztandó, elég arra a szavunkra gondolni, amelyet előszeretettel használunk magunkra: individuum. Mi azok vagyunk, akik „,feloszthatatlanok”, „egységesek”. Talán nem túlzás azt állítani, hogy alaptapasztalatunk, hogy egy ilyen oszthatatlan ego rezidál valahol a szemeink mögött, tapasztal, mérlegel, racionális (legalábbis igyekszik az lenni), emlékezik, döntéseket hoz, cselekszik, személyiségjegyekkel bír stb. Csakhogy ez a tapasztalt egységesség csalóka. Metzinger szavaival: „úgy tünik, nincs empirikus bizonyíték, sem igazán meggyőző konceptuális érv annak alátámasztására, hogy ténylegesen létezik «egy» self” (2011 p. 277). A selfről való gondolkodás történetét Barresi és Martin (2011) az alábbi módon foglalja össze.

„Szolgálatba állítottuk a selfet, hogy átvegye a helyét [értsd: a léleknek], hogy egységességet és irányt biztosítson az emberi személynek (...) Gyakorlatilag a tudomány fogta az ént mint lelket az égben, és lehozta a földre az egységes én öltözékében. Mint a léleknek, a selfnek is az lett volna a feladata, hogy az egységnek, hatalomnak, szabadságnak, kontrollnak és perzisztenciának a forrása legyen. (...) Hamarosan, ami egy volt - az én - sokasággá vált. Ami valós, fikcióvá. És ami korábban magyarázatok forrása volt, önmaga is magyarázandó dologgá vált" (Barresi és Martin 2011, p. 55).

Az is beszédes, hogy a Shaun Gallagher által szerkesztett Oxford Handbook of the Self c. kötet szerzői közül senki sem érvel egy karteziánus self létezése mellett: a legtöbben azok közül, akik a selfet hasonló szempontból vizsgálják, legfeljebb egy „minimális” self létét posztulálják, vagy annál is kevesebbet (Gallagher 2011, p. 7).

Az alábbiakban az „én” némely egységesnek tapasztalt aspektusáról igyekszem bemutatni, hogy valójában nem olyan egységesen müködik, ahogy azt hisszük. A konkrét példákra azért van szükség, hogy a „saját bőrünkön” érezzük az emlegetett feloszthatóságot, és az alfejezet fö tézise is kézzelfoghatóbbá váljon, miszerint sokkal inkább dividuumok vagyunk, mint individuumok.

A racionalitás nem egységes. A pszichológiai architektúránk heurisztikákat tartalmaz, tehát olyan egyszerüsítéseket, torzításokat és hibákat, amelyek mentén két rendszerre lehet bontani (Kahneman és Tversky 1982). Kahneman (2011) híres tudományos ismeretterjesztő 
könyve nyomán a bevett megnevezés az „1. és 2. rendszer”. ${ }^{87}$ Az 1. rendszer a könnyü, gyors, automatikus válaszokért felel, a 2. rendszer nehéz, lassú és koncentrációt igényel. Egy kérdéssel könnyü illusztrálni a különbséget.

- Egy baseball-labda és egy ütő összesen 110 dollár. Az ütő pontosan 100 dollárral több, mint a labda. Mennyibe kerül a baseball-labda?

Könnyen és magától adódik egy megoldás, mégpedig a 10 dollár. Csakhogy ez rossz megoldás. (A helyes válasz: 5 dollár.)

A heurisztikák szabályszerüségek mentén, következetesen tévútra vezetnek bennünket, és sokszor még a tudatosítás, a 2. rendszer igénybevételével sem lehet őket megszüntetni. Az ún. horgonyhatás jó példa erre. Alanyok teljesen véletlenszerủen kaptak egy-egy számot; a 10-et vagy a 65-öt, majd válaszolniuk kellett arra a kérdésre, hogy „mekkora az ENSZ-ben résztvevő afrikai nemzetek aránya?” A 10-nek és a 65-nek semmi köze sem az ENSZ-hez, sem az afrikai nemzetekhez, és ezt az alanyok is tudták; mégis, akik a 10-es számot kapták, 25\%ra tippeltek, akik a 65-ös számot, azok 45\%-ra. A horgonyhatás egyébként tipikusan olyan példa, ahol a tudatos kiigazítási szándékkal sem tudjuk kivonni magunkat a teljesen véletlenszerü, oda nem is kapcsolódó „horgony” hatása alól. Olyan heurisztikákra, amelyek a racionálisnak szánt döntéseinket igencsak kontraintuitív módon, de kimutathatóan, szisztematikusan befolyásolják, sok példát lehetne még hozni, melyek közül néhányat még érintünk a dolgozat során.

Egy másik megemlítendő törésvonal a tapasztalat és emlékezet között áll fenn, és szintén Kahneman és mtsai. (1993, 1996) kutatásaihoz kapcsolódik. A kísérletben betegeket kértek fel, akik épp fájdalmas kolonoszkópián estek át, hogy jelöljék percenként, hogy 0-10-ig terjedő skálán mekkora fájdalmat élnek át. Vegyünk közülük két beteget, A-t és B-t. Előbbi mütétje 8 percig, utóbbié 24 percig tartott. Mindkettőjüknek volt kiugrósan magasra (8-asra) értékelt fájdalomérzete, továbbá kevésbé fájdalmas percei is; ha arányaiban megnézzük, a két beteg hasonló mennyiségü fájdalmat élt át (ha feltételezzük, hogy hasonlóan értelmezték a fájdalmi skálát). A legfeltűnőbb különbség kettejük közt a mütét hossza volt. Ha A beteg X mennyiségü fájdalmat érzett, akkor B beteg, mivel háromszor hosszabb volt a mütét ideje, $3 \mathrm{X}$ mennyiségü fájdalmat. Ha választanunk kellene, hogy A beteg X mértékü fájdalommal járó

\footnotetext{
87 Két fontos megjegyzés: a rendszerek minimalista elnevezését Kahneman Keith Stanovichtól és Richard Westtől veszi át. És ami még fontosabb, a rendszerekre úgy érdemes tekinteni, mint egyszerüsítő eszközökre, cimkékre, amelyek egy halom folyamatot takarnak valójában. Értve ezalatt azt, hogy az 1. és 2. rendszer nem (vagy nem biztosan) léteznek saját jogukon mint entitások.
} 
vagy $\mathrm{B}$ beteg $3 \mathrm{X}$ fájdalommal járó mütétjén szeretnénk inkább átesni, nem kérdés, hogy melyik mellett döntenénk. Csakhogy rosszul döntenénk.

Ez akkor válik nyilvánvalóvá, amikor a valós idejü fájdalomérzet-jelentéseket összevetjük azzal, ahogy a betegek utólag visszaemlékeztek a mütétre, és pontozták azt. A kísérlet vezetői azt tapasztalták, hogy az időtartam meglepő módon egyáltalán nem játszik szerepet az értékelésben. E szabályszerüség az időtartam iránti közömbösség (duration neglect) nevet kapta. Ami szerepet játszott, az a csúcsérték, jelen esetben a legmagasabbra értékelt fájdalomérzet, ami A és B esetében egyaránt 8 volt. Ebben nincs semmi kontraintuitív. De mi lehet akkor annak az oka, hogy A sokkal rosszabb emlékekkel távozott a mütétről, mint B? Meglepő módon az, hogy A esetében az utolsó pontérték 7, míg B esetében csak 1 volt. Az élmény összesített értékelésében a végső érték játszik döntő szerepet, és mivel ez B esetében jóval alacsonyabb volt, ő így összességében kevésbé rossz élményre emlékszik. Ez a szabályszerüség a csúcsérték-végső érték szabály (peak-end rule): a csúcsérték és végső érték átlaga pontosan jelzi az összesített retrospektív pontértéket. És itt válik külön a tapasztalat két fajtája: ahogy itt és most átélünk valamit, és ahogy emlékezünk arra. A tapasztaló én és az emlékező én között világosan látszik a törésvonal. A tapasztaló én élménye elfelejtődik: az emlékező én alakít ki róla egy összesítőt a fenti szabályok szerint, és ez alapján dokumentálja azt. (Később pedig ez alapján hozunk döntéseket.) Az, hogy emlékezhetnénk a tapasztaló én által átélt élményekre, kognitív illúzió csupán.

Térjünk át a személyiségre. Valójában az én, a self mint a viselkedés forrása nem olyan robosztus, mint ahogy azt tapasztaljuk vagy hinni szeretnénk. A szociálpszichológia egyik legjobban dokumentált jelensége a fundamentális attribúciós hiba (fundamental attribution error, Ross 1977). Ennek lényege, hogy hajlamosak vagyunk a viselkedést az ágens diszpozícióinak tulajdonítani, és ezzel szemben elsiklani meghatározó szituációs tényezők felett: magyarán kauzális magyarázataink során az individuumot és annak tulajdonságait (személyiségjegyeit) helyezzük a középpontba, holott gyakran ezek valójában nem, vagy csak sokkal kevésbé játszanak szerepet a viselkedésben, mint hisszük. Talán a legjobb példa erre a hibára ,jó szamaritánus” kísérlet (Darley és Batson, 1973). Amikor az alanyoknak egy teremből át kellett mennie egy másik terembe, találkoztak egy folyosón fekvő (beépített) emberrel, aki nyilvánvalóan segítségre szorult. Azt, hogy melyik alany áll meg segíteni, az határozza meg, hogy milyen ember (milyen tulajdonságai, személyiségjegyei vannak, stb.), gondolnánk - csakhogy tévednénk. Az, hogy az adott alanyok mennyire vallásosak, erkölcsösek, összehasonlíthatatlanul gyengébb prediktív faktor volt, mint azon egyszerü tény, hogy a kísérletvezetők azt mondták-e nekik, hogy késésben vannak. Irónikus 
módon ez akkor is igaz volt, amikor az alanyok épp a jó szamaritánusról siettek előadást tartani. Továbbá nem csak mások viselkedését magyarázzuk (sokszor félre) az ágens tulajdonságai alapján, hanem a sajátunkat is: a viselkedésünkről szóló narrációk kauzális magyarázataiban a self és annak tulajdonságai állnak a középpontban, holott sokszor nem ezért cselekedtünk úgy, ahogy.

A szociálpszichológia ehhez hasonló, meghökkentő eredményei azt mutatják, hogy az emberi döntések sokszor sokkal inkább egészen apró szituációs kontingenciákon múlnak, mint az ágens jellemén vagy racionális döntésein. Ezek az eredmények olyan irányba mutatnak, legalábbis prima facie, hogy nincsenek olyan, stabil karakterjegyek, amelyek fennmaradnának a különböző szituációk között. Ez a nézet a törékeny kontroll hipotézis (frail control hypothesis), amelynek egyik legszélsőségesebb képviselője Doris $(1998 ; 2002)^{88}$. E hipotézis azt állítja, hogy az externális tényezők között „feloldódik” a személyiség, mely többé nem rendelkezik internálisan megragadható viselkedési diszpozíciókkal. Doris, egyéb szituacionista szerzők és a fundamentális attribúciós hibára rámutató kísérletei szerint egy kogitáló alany viselkedése egy adott helyzetben nem bejósolható karakterológiai meghatározottságai alapján. Nem tudjuk azt mondani, hogy a jó szamaritánus, mivel jó, meg fog állni segíteni. Ezzel szemben bizonyos externális faktorok viszonylag megbízható prediktív erővel bírnak. Ha nem is feltétlenül mennék olyan messzire, mint Doris, de az externális elemek drasztikus hatását és az ezzel járó kihívást komolyan kell venni. Márpedig ez egy olyan kihívás, amelyik az „én”-ről alkotott fogalmunk revíziójára késztet.

Természetesen a viselkedés alakulásából nem zárható ki az internális elem. Egy olyan egyed, aki például kifejezetten utálja, ha siettetik, lehet, hogy éppen ezért fog megállni segíteni a bajba jutott beépített emberen. De fontos látni, hogy az externalitás sem zárható ki: úgy tűnik, a viselkedés valami olyasmi, ami a kettő interakciójából emelkedik ki; ezek az eredmények pedig sokkal jobban illeszkednek a kiterjedt elme keretébe, mint az internalista, egységes én-képet feltételező felfogásokéba. ${ }^{89}$

Úgy tünik tehát, hogy az ,elfogadhatatlan én-kép” ellenvetés nem állja meg a helyét. Még egyszer: az ellenvetés szerint a kiterjedt elme hipotézis nem elfogadható, ugyanis bizarr vagy elfogadhatatlan én-kép következik belőle. Én inkább épp a fordítottját látom: adott egy tudományos eredmények által motivált bizarr én-kép, amely a kiterjedt elme hipotézissel

\footnotetext{
${ }^{88}$ Doris erényetikai és a szabad akarattal kapcsolatos megfontolásból közelít ehhez a problémához, de a párhuzam szoros.

${ }^{89} A d$ hoc jelleggel hoztam fel éppen ezeket a példákat, de reményeim szerint az én egységességébe vetett mély hitünket és az ezzel kapcsolatos intuíciókat sikerült némiképp megingatni általuk. A téma természetesen ennél hosszabb, legalább disszertáció terjedelmű kifejtést érdemelne, amire sajnon nincs módunk.
} 
sokkal inkább összhangban van, mint az internális felfogások. Ennélfogva inkább az internalista felfogásokat érdemes elvetni.

\subsection{A dilemma: túl kicsi és túl nagy elmék}

Clark és Chalmers gondolatmenete mindenképp egy fájdalmas dilemma elé állít, mely választás mindkét opciója kontraintuitív. Ebben áll a gondolatmenet zsenialitása is: kénytelenek vagyunk új módon kezdeni gondolkodni a gondolkodásról. A két opció: az elmék vagy túl nagyok, vagy túl kicsik lesznek.

Gertler (2007) szerint a Clark és Chalmers gondolatmenete mögött lévő két lényegi kondicionális a következő:

(1) Ha a nem okkurens hitek részei az elmének, akkor az elme meghatározatlanul kiterjedhet: noteszekbe, externális komputációs eszközökbe, és akár más emberek elméjébe is.

(2) Ha a nem tudatos kognitív folyamatok részei az elmének, akkor az elme meghatározatlanul kiterjedhet: externális komputációs eszközökbe, és akár más emberek elméjébe is.

Gertler szerint ezek a kondicionálisok elfogadhatóak. Ha beengedjük a nem okkurens állapotokat és nem tudatos folyamatokat a genuin mentális világba, abból valóban következik a kiterjedt elme állítása. Mit tehet ilyenkor, aki ezt a következményt nem tartja elfogadhatónak valamely (remélhetőleg) általam is tárgyalt aggály miatt?

Természetesen tagadhatja, hogy a nem okkurens hitek és nem tudatos folyamatok a mentális genuin részei lennének, ezzel hatástalanítva a kondicionális kényszerítő erejét. Gertler például ezt az utat választja, koncepcióját „szűk elmének” keresztelve. Az elme ebben az esetben csak és kizárólag okkurens mentális állapotokból és tudatos kognitív folyamatokból áll.

Érdekes módon Gertler számára elfogadható egy hit lokációjának akcidentalitása, azaz nem az externális voltuk miatt akarja kizárni az externális elemeket a genuin kognícióból, hanem a nem okkurens állapotok és nem tudatos folyamatok cselekvésben játszott szerepe miatt. Ezek ugyanis, függetlenül attól, hogy internálisak vagy externálisak, ha mentálisnak tekinthetőek, akkor az a Gertler szerint elfogadhatatlan helyzet adódik, melyet a cselekvések 
proliferációja ellenvetésben tárgyaltunk: hogy Otto egyszerre több helyen, több mindent csinálhat robottestekben.

Tehát egy ágens genuin cselekedetének csak azon cselekedeteket tartja, amelyek tudatos mentális állapotoké és folyamatoké, ahol „tudatosság” alatt azt érti, hogy introspekció tárgyát képezhetik. Gertler tisztában van vele, hogy ez meglepő és kontraintuitív álláspont, hogy némely agy által realizált nem okkurens állapot és nem tudatos folyamat nem alkotja az elme részét, s hogy ezek nem mentálisak, de összességében mégis kevésbé kontraintuitívnak tartja, mint a másik lehetőséget, tehát a kiterjedt elmét.

Számomra azonban ez túl nagy árnak tünik. Egyrészt azért is, mert Gertler fő motivációja ezen ár megfizetése mögött a cselekedetek proliferációs aggálya, mely nem túl meggyőző, mint azt korábban igyekeztem bemutatni. (Természetesen egyéb ellenvetés is állhat a háttérben.) Másrészt azért, mert a szük elme csak első ránézésre tünik kevésbé kontraintuitívnek. Lássuk, miért.

Ha az introspekció tárgyává tehető, és ilyen értelemben tudatos mentális állapotok és folyamatok alkotják a cselekvések alanyaként felfogott genuin elmét, akkor azon cselekedeteink száma, amelyeket genuin módon a saját cselekedeteinkként szeretnénk elgondolni, túlságosan leszükül. ,. Vegyük például a „Florida-hatás” elnevezésű pszichológiai jelenséget, mely az „előfeszítés” (priming) egy fajtája, mely pedig az ideomotoros akció egy fajtája. Az ideomotoros akció lényege, hogy bizonyos externális stimulusok automatikusan előidéznek valamilyen viselkedést, anélkül, hogy bármiféle tudatos percepcionális vagy ítélkezési folyamat részt venne bennük (Bargh és mtsai. 1996). Alanyok kimutatható mértékben más tempóban mennek át egyik helyről a másikra, attól függően, hogy „előfeszítették”-e bennük az öregséggel kapcsolatos tudattalan asszociációkat. Az alanyoknak fel sem tünik az előfeszítés, mégis másmilyen sebességgel mennek. Ez az előfeszítés nem tehető introspekció tárgyává. Gertler gondolatmenetét követve a sétálás tényének az alanyok maguk az ágensei, de a sétálás sebességének már nem. Akkor kik? Ezek szerint cselekedeteink mögött (mindig? néha?) két ágens lapul: az egyik tudatos, a másik tudattalan, és ez utóbbi cselekedetei miatt nem is vagyok felelőssé tehető. Ez egyrészt meglehetősen kontraintuitív, másrészt Ockham borotvájáért kiált.

Egy további érv, hogy miért érdemes a nem okkurens állapotokat is az elme részének tartani, épp a kiterjedt elme ellen felhozott érvben szereplő jelenségből származik: e szerint az Otto noteszében található információk statikusak; nem vesznek részt azon dinamikus folyamatokban, amelyek révén a mentális állapotok folyamatosan alakulnak, összeolvadnak és egyéb módokon hatnak egymásra. (És az ellenvetés szerint éppen ezért nem lehet az elme 
részének tartani a notesz információit.) Gertler erre vajon azt mondaná, hogy ugyan okkurens és nem okkurens állapotok dinamikusan folyamatosan hatnak egymásra, átalakulnak, egymásba olvadnak, de ennek a fluid valaminek csak bizonyos részei mentálisak? Mi alapján tudunk individuálni? Ez tehát szintén problematikusnak tünik.

Azt, hogy számomra introspekció révén mi elérhető, és az hogyan jelenik meg, mindig nem tudatosuló folyamatok határozzák meg, ezzel olyan kontinuumot alkotva „,igazi mentális” és ,„pusztán kognitív” állapotok és folyamatok között, amelyek - Gertler intenciója szerinti különválasztása csak olyan erőszakkal lehetséges, mely számomra nem tünik elfogadhatónak. Erre céloz Clark és Chalmers is, amikor ezt írják: „Hogy következetesen ellenálljunk a konklúziónak [miszerint Otto maga egy kiterjedt rendszer], a selfet le kellene szükíteni egy halom okkurens állapotra, komolyan fenyegetvén annak mély pszichológiai kontinuitását" (Clark és Chalmers 2010, p. 18). Illetve máshol: „A legtöbben elfogadjuk, hogy az én túlnő a tudatosság határain: például a diszpozicionális hiteim egy mély értelemben konstituálják egy részét annak, aki vagyok" (Clark és Chalmers, 2010, p. 39. Kiemelés tőlem.). Például hiába vagyunk alapvetően elöítéletmentesek más csoportokkal szemben (vagy tartjuk magunkat annak), mégis kimutathatóak bizonyos elöítéleteink, amelyek befolyásolnak minket a döntéshozatalban (Dasgubta 2004). Ezek az implicit elöítéletek is alkotják azt, akik vagyunk, és ahogy viselkedünk, tehát az érvelésem szerint én-képünknek is magában kellene foglalnia. Megint máshol Clark a következőt mondja:

„De (...) ha nem tekintjük mindezt a hosszú távon tárolt tudást az elmém és selfem részben konstitutív részének, azzal elszakítjuk az identitásomat mint ágenst az emlékek és diszpozicionális hitek egész seregétől, amely irányítja és alakítja a viselkedésemet. És ez, fenntartom, a felismerhetetlenségig összezsugorítja az elmét és a selfet” (Clark 2010a, p. 56).

A szük elme tehát túl szük, és egyáltalán nem biztos, hogy kevésbé kontraintuitív vagy problémamentes, mint a kiterjedt elme. Továbbá nem tủnik úgy, hogy a tudományos kutatások szemszögéből bármilyen pozitív hozadékkal járna, ugyanis legfeljebb annyit állíthat, hogy az „igazi” mentális világot nem kell a kognitív tudományoknak kutatnia, az ugyanis introspekció révén feltárható. Csakhogy, amint azt az „Elfogadhatatlan én-kép” fejezetben is láttuk, az instrospekció révén konzisztensen elsiklunk szabályszerüségek felett, tévedünk, stb. (a kognitív karteziánus démon legalapvetőbb introspekcióinkban is megtéveszt), amelyek szintén alkotják ezt az internális világot; valamint az introspekció révén feltárható és nem feltárható világ állandó interakcióban áll egymással, amit nem lehet 
egykönnyen szétválasztani. Ezzel szemben a kiterjedt elme és egyéb szituált elméletek tudományosan gyülölcsözőnek tekinthetőek, amennyiben új kutatási irányokat jelölnek ki.

Így a „túl kicsi vagy túl nagy elme” dilemmában inkább az utóbbi mellett teszem le a voksot, és a továbbiakban megkísérlek a lehető leginkább intuitíve elfogadható módon gondolkodni róla.

\subsection{A „második hullám”}

\subsubsection{A kiterjedt fenotípus és az emberi transzformer}

A zsinórférgek úgy vadásznak, hogy „kilógatnak” magukból egy hosszú, ragadós szálat: habár hasonlít valamennyire egy pókhálóhoz, a szál szervesen hozzátartozik az organizmus testéhez, ahogy például a kaméleon nyelve is része a kaméleon testének. Tegyük fel, hogy létezik egy olyan pókfaj, melynek egyedei épp olyanok, mint a zsinórféreg abban a tekintetben, hogy nekik is a testükhöz tartozó, önmagukból kilógatott hálójuk van, ami azonban teljesen megegyezik minden másban az ismert pókok hálóival, tehát valahogy hasonlóan használják, mint az emberek az ejtőernyőt: gondosan össze kell hajtogatni használat után, hogy elférjen és rendesen kinyíljon legközelebb, de ez nem lehetetlen. Tegyük fel azt is, hogy a „kihajtogatás” ugyanannyi időt vesz igénybe, mint egy aktuális póknak megszőni a hálóját. Minden másban egyformák.

Most pedig vegyük igénybe a Clark és Chalmers által metabolikus tudatlanság fátylának nevezett gondolati eszközt, csak épp a fátylat az evolúciós folyamatokra terítsük rá. Ahogy a Turing-tesztnél, csakis az outputokat ismerhetjük, azt viszont nem, hogy a másik oldalon ki és hogyan jut el az outputok létrehozásához; az evolúciós tudatlanság fátyla esetében azt nem tudjuk, hogy a túloldalon lévő egyed hogyan képes replikálni a génjeit, csak azt, hogy milyen sikeresen, ez ugyanis az evolúciós játszma egyetlen tétje.

A kikötés szerint fiktív és aktuális pókfajunk ugyanolyan effektíven használja saját hálóját. A kérdés az, vajon lesz-e különbség kettejük szaporodási esélyei közt? A vadászatuk folyamatának implementációjában lesz különbség, de ezt épp most tettük zárójelbe: a fontos az, hogy génjeiket ugyanolyan sikeresen tudják-e majd lemásolni, mint aktuális testvéreik. Nem könnyü belátni, hogy ez miért ne lenne így, hiszen a két faj ugyanolyan sikeresen szerez 
táplálékot. Az evolúciót egyszerüen nem érdekli, hogy a háló része-e az organizmus testének, míg hatékonyan lehet használni. ${ }^{90}$

A példa fokozatossága miatt ez a gondolatmenet remélhetőleg kevésbé bántja az organizmusokról és azok határairól való gondolkodás mélyén fekvő (valószínűleg esszencialista) intuícióinkat, de ugyanoda vezet, ahova Dawkinsé, amikor a kiterjedt fenotípus fogalmát vezeti be.

„A tegzesek háza nyilvánvalóan nem része a sejtjeik alkotta testnek, jóllehet igen meghitten öleli körbe azt. Ha a testet a gének hordozójának vagy túlélőgépnek tekintjük, nem nehéz a tegzes kavicsokból épített házában egyfajta különösen hatásos védelmet nyújtó falat látnunk, amely bizonyos funkcionális értelemben a hordozó legkülső rétege - csak éppen kőből, nem pedig kitinből épül fel. Most nézzünk egy olyan pókot, amely hálója közepén ül. Ha gének hordozójának tekintjük, hálója nem fogható fel ugyanabban az értelemben e hordozó részeként, mint a tegzes háza, mivel ha a pók megfordul, a háló nem fordul meg vele együtt. Ez a különbségtétel azonban nyilvánvalóan semmitmondó, és a pók hálóját is nyugodtan tekinthetjük teste ideiglenes funkcionális kiterjesztésének, amely óriási mértékben megnöveli zsákmányszerző szerveinek tényleges hatókörét” (Dawkins, 1989, p. 214).

A tegzesek ${ }^{91}$ életének elengedhetetlen része a kavicsokból felépített ház: a külvilágban található externális elemeket építik „be” magukba, és ezek az elemek egy mély (ha nem is szó szerinti) értelemben részei az organizmusnak. A házépítés genetikailag kódolt, így azok nem mutatnak lényeges variációt az egyedek között. De mi lenne, ha mutatnának? Ha a tegzesek például az alapján építenék meg (vagy akár át) a házukat, hogy az adott környezetben a lehető legjobb védelmet nyújtsa? Ez számottevő evolúciós előnyt jelentene, hiszen jobban tudnának alkalmazkodni a környezeti változásokhoz, mint a fix házakat építők, és így génjeiket is sikeresebben örökítenék tovább. A fix házakat már (számomra legalábbis meggyőző módon) megtettük a tegzesek mint túlélő rendszerek részének, és nem látszik lényegi különbség akkor sem, ha ezek átalakíthatóak; sőt az evolúciós tudatlanság fátylán túlról csupán annyi látszik, hogy az egyik igen csak kreatív tegzesfaj messze sikeresebb egy másiknál. Ahhoz ugyanis, hogy a fix házakat építő tegzes alkalmazkodjon az új környezethez, genetikai változás szükséges, ami pedig sok időt igényel.

\footnotetext{
${ }^{90}$ Az evolúciót természetesen semmi sem ,érdekli”, hiszen egy vak algoritmus. Ezt úgy kell érteni, hogy az evolúciós szempontok szerint irreleváns; nem változtat a génörökítés szempontjából.

${ }^{91}$ A dolgozat szerzője valójában semmit nem tud a tényleges tegzesekről, de ezt nem is igényli a gondolatmenet; nyugodtan elgondolhatunk helyette egy fiktív fajt is.
} 
Most pedig térjünk át egy aktuálisan kreatív fajhoz, mely rendszeresen alakít át externális elemeket, hogy az a lehető leghatékonyabban segítse őt mint túlélö rendszert: az emberre. Annyira természetes számunkra a mindenféle eszközök használata, hogy fel sem tünik, hogy ez valójában mennyire különleges az élővilágban. Vegyük példaként az egyszerü ruházkodást: a tegzesekkel való analógia mentén, amennyiben a házat az organizmus részeként fogadtuk el, miért ne tennénk ezt az ember viselte ruhákkal is? Ódzkodhatunk ettől, hiszen: (1) ruhát nem muszáj viselni (habár minden ismert kultúra visel valamilyen fajta ruhát, még ha ezek nagy eltéréseket mutatnak is); (2) könnyen és gyakran szabadulunk meg tőlük; (3) nem mi készítjük el őket (ahogy például a tegzes a házát).

Csakhogy ezek mind felszínes különbségek. Az állatvilágban is szokás vedleni, új bundát növeszteni télire, stb., így ez pusztán fokozatbeli különbség: (2) tehát nem lehet döntő kritérium annak eldöntésében, hogy egy elem része-e az organizmusnak. Továbbá lehetséges olyan faj, amelyik szintén házakat használ védelemre, csakhogy ezeket a tegzesekkel ellentétben már készen találja; mégse mondanánk, hogy a tegzesektől lényeges módon különböznek. És ha egy ilyen fajt beengedünk ezen a kapun, akkor az embert és ruháját is be kell engednünk.

Korábban azt állítottuk, hogy az evolúciót nem érdekli, hogy egy organizmus testéhez tartozik-e valami, míg betölti a funkcióját. Azután a kreatív tegzeseknél láttuk, hogy más szempontból mégis csak számít, hiszen egy externális elem összehasonlíthatatlanul gyorsabban képes változni, mint egy genetikailag kódolt biológiai elem: mondhatni az organizmuson kívülre (is) került az evolúció. Gondoljunk bele a plusz réteg ruha felvétele és egy vastagabb bunda növesztése mögött meghúzódó vakvéletlen mutációkon alapuló folyamatok közti időbeli különbségekbe.

De nem csak a változások gyorsasága jelent evolúciós előnyt. Az ilyen cserélhető elemek sérülése sokkal kisebb problémát jelent az organizmusnak, mint ha a konkrét testét érné sérülés; regenerációjának képessége vagy extra védelmének kialakítása ugyan csak drága evolúciós szempontból. Dennettet parafrazálva, ${ }^{92}$ aki a popperi teremtmények esetében az ötletekröl állítja, hogy meghalnak az organizmusok helyett, amikor egy problémát nem próbaszerencse útján igyekeznek megoldani, hanem gondolkodás útján; úgy az externális elemeket beépítő organizmusok e külső elemeket hagyják „,meghalni” maguk helyett.

\footnotetext{
92 Dennett több helyen is foglalkozik a különböző teremtményekkel (skinneri, popperi, stb.). Lásd pl. Dennett 1997.
} 
„Az emberi kezek megjelenésével a test alkalmazkodásának régimódi formája elavulttá vált. A fejletlenebb állatok az autoplasztikus evolúció termékei voltak, így testük a túlélésért folytatott vak genetikai játszma adaptációs gyakorlatának volt kiszolgáltatva. A játék tétje igen nagy volt: élet vagy halál. Az ember evolúciója azonban alloplasztikus próbák során zajlik, amelynek tárgya a testen kívül található, csupán kezének, agyának és szemének termékeit érinti - nem pedig magát a testet” (Barre 1954, p. 90).

Vegyünk most egy csupán a populáris kultúra képzeletében létező fajt, a Transzformert. Ezek lényegében olyan robotok, akik alakváltoztatásra képesek. Habár ők főként autók és humanoid alakjuk között váltogatnak, tegyük fel, hogy alakváltoztatásuk képessége gyakorlatilag végtelen. Ha késre van szükségük, kezük késsé alakul, ha kalapácsra, kalapáccsá. De ha egzotikusabb tevékenységet űznek, szárnyat növesztenek vagy békalábat. Tegyük fel, hogy Ikerföldet ilyen transzformerek népesítik be, és terítsük rá a bolygóra az evolúciós tudatlanság fátylát.

Ha zárójelezzük a folyamatok implementációit, tulajdonképpen mi a különbség a transzformerek és az emberi lények között? A testem nem tud autóvá, a kezem se késsé, se kalapáccsá alakulni, nincsenek szárnyaim vagy békalábam; de be tudok ülni autóba, elővehetek a fiókból kést és kalapácsot. Ha nagyon rászorulok, elsétálhatok egy üzletbe békalábért. A szárny már nehezebb ügy: egy repülőteres több órás várakozás nehezen feleltethető meg a szárnynövesztésnek, csakhogy ez elég esetleges és tisztán technikai kérdés: a jetpackek vagy drónbiciklik térnyerésével hamar megváltozhat a helyzet. Túlélési szempontból egyedül az képezhet számottevő különbséget (és ebben a transzformerek egyelöre valóban jobbnak tűnnek, már amennyire ennek van értelme fiktív lények esetében ${ }^{93}$ ), hogy gyorsabban képesek a helyzethez adaptálódni. Gyorsabban alakítják késsé a kezüket vagy békalábbá a lábukat, mint ahogy mi elmegyünk az üzletbe venni egyet, stb. Ez a különbség akkor viszont eltünik, ha az emberek az externális elemeket még jobban integrálják saját rendszerükbe, ezáltal pedig ezek használata gyorsabb és hatékonyabb lesz. Mindenesetre látható, hogy ez csupán fokozatbeli különbség. Nem az implementáció izomorfiája jelentős, hanem az integráció mértéke. Az, hogy az emberi lényeknek mint replikátor-rendszereknek meddig terjed a határa, nehéz kérdés, és szépen összecseng a határtalan elme/kognitív felfúvódás ellenvetés problémájával. Vajon egy általam rendszeresen használt konyhakés

\footnotetext{
${ }^{93}$ Ha viszont a transzformerek kialakulásának esélyeit nézzük, ők állnak rosszabbul, hiszen felbecsülni is nehéz (ha nem lehetetlen) mennyi időre lenne szükség, hogy egy ilyen general-purpose gép, ami bármivé tudja alakítani magát, létrejöhessen (amennyiben egyáltalán lehetséges). Hacsak nem a miénkhez hasonló evolúciós folyamat vezetett oda, hogy létrehozták a génmanipulációt, és így a „kinti” evolúció összeolvad a „,bentivel”.
} 
számít csupán bele ebbe a rendszerbe, vagy az összes könnyen elérhető üzletben található kés, az összes szomszédom összes kése, amit kölcsön kérhetek, vagy akár a világ összes kése? Netán akár az összes létező szerszám a rendszerem részét képezi? Ha segítenek a túlélésben, akkor miért ne? Hogy egy kognitív példát is hozzunk: tegyük fel, hogy meglőttek, és éppen vérzek el. Magamtól nem tudom, hogyan kell ellátni a lőtt sebet, de az ájulás előtt felmegyek a Wikihow webolalra, ${ }^{94}$ ahol lépésről lépésre segítenek, és éppen ezért túlélem a sérülést. Ha az ilyen tudás az egész faj számára elérhető, akkor az az evolúciós tudatlanság fátyla mögül éppen olyan, mintha a tudás genetikailag lenne bennünk kódolva. Más lehet a helyzet a „steril szöveg" esetén: ${ }^{95}$ ha példáuk a Wikihow szövegét nem értem, akkor nem is tudok megfelelően cselekedni, tehát nehéz lenne azt állítani, hogy tudom bármilyen értelemben, miként kell kezelni egy lőtt sebet, és ebben az esetben annak rendje és módja szerint el is vérzek. De ebből is csak az látszik, hogy az integráció, a használhatóság a lényeges szempont. A „steril szöveg” nincs integrálva a rendszerbe, ezért nem is képezi részét. Ebben a kérdésben természetesen jobban is elmerülhetnénk, de kénytelenek vagyunk rövidre zárni fejtegetéseinket. Összegzésképp: leginkább az externális eszközeink integrációjának mértékén múlik, hogy már most transzformerek vagyunk-e funkcionális értelemben. Ez pedig az evolúciós tudatlanság fátylának szem előtt tartásával lényegében azt jelenti, hogy biológiai értelemben is.

Erre a kitérőre azért volt szükség, mert a test és eszközök integrált rendszereivel jól látható, ami a kiterjedt elme „második hullámának” központjában áll: a paritás helyett a komplementeritás. Az eszközöknek épp azért van értelmük, mert nem utánozzák olyan képességeinket, melyekkel biológiai testünk már eleve rendelkezik - ha pusztán utánoznák azokat, akkor kevésbé, vagy egyáltalán nem lenne rájuk szükség. Vagyis pontosan olyan cselekvéseket tesznek lehetővé, melyekre biológiai testünk nem, vagy csak más mértékben képes.

\subsubsection{A komplementaritás elve}

Clark szerint a fentiek igazak mentális folyamatainkra és vállalkozásainkra is. Clark így ír: ,alapvető emberi természetünk, hogy nem-biológiai dolgokat mélyen hozzácsatoljunk

\footnotetext{
${ }^{94} \mathrm{https}: / /$ www. wikihow.com/Treat-a-Bullet-Wound

${ }^{95}$ Clark (2010) is foglalkozik a „steril szöveg” ellenvetéssel, amely ellenvetést Dartnall személyes közlésének tulajdonít.
} 
mentális profilunkhoz, ilyen dolgokat állítsunk mentális profilunk használatába, valamint egyesítsünk azzal” (Clark 2003, p. 198).

Ahogy a fentiekben az organizmus határai váltak mellékessé, úgy itt a kognícióé válnak azzá. Clark ezt úgy fogalmazza meg, hogy „egyre okosabbá tesszük a világot, hogy mi magunk nyugodtan buták maradhassunk" (Clark 1997, p. 180).

A korábban tárgyalt ellenvetések jelentős hányada származott abból a tényből, hogy az externális és internális folyamatok különbözőek bizonyos szempontokból. Otto noteszének példáját igyekeztek oly módon megszerkeszteni a szerzők, hogy a lehető leghasonlóbb legyen Inga biológiai agyához. És habár módszertani szempontból egyetértünk ezzel a megközelítéssel (hiszen makacs karteziánus intuícióink és elöítéleteink fokozatos támadások nélkül aligha kerülnének revízióra), ennek hangsúlyozása a gondolatmenet szempontjából nem feltétlenül a legszerencsésebb, hisz túlságosan a hasonlóságra fókuszálja a fígyelmet.

Otto hátrányos helyzetből indul, hiszen Alzheimer-kóros: igyekszik oly módon augmentálni a memóriáját, hogy képes legyen az egészséges emberekhez hasonlóan viselkedni.. Ugyanez a helyzet azokkal, akiknek hiányzik valamelyik végtagjuk: a protézisek egyre kevésbé ugyan, de még mindig távol állnak tőle, hogy ugyanolyanok legyenek, mint az igaziak. De mi lenne, ha ahelyett, hogy arra fókuszálnánk, mennyiben különbözőek ezek az externális elemek, és ezek távolságát próbálnánk csökkenteni az eredetiektől, inkább az ebben rejlő előnyökre fókuszálnánk?

Az írott szó egyik legnagyobb előnye éppen az, hogy másmilyen, mint a biológiai memória. „A szó elszáll” (legalábbis a memória mindenféle törvényszerüségeinek alá van rendelve), ,az írás megmarad”: mégpedig statikusan. A mai technológia távol van attól, hogy vakoknak visszaadja a látást (habár erre is vannak igéretes eredmények néhány pixel erejéig), de például éjjellátó szemüvegekkel lehetővé teszi a katonáknak, hogy lássanak sötétben is; a protézisek spektrumának túlsó végen pedig az exo-skeletonokat említhetjük, melyek erősebbé, gyorsabbá tehetik viselőjét. A teljesítmény növelése is lehet cél, nem csak a teljesítmény kiegyenlítése - habár természetesen ez is nagyon fontos. A Holan és Stornetta (1992) szerzőpáros ezt úgy fogalmazta meg, hogy „nem a mankókra, hanem a futócipőkre” érdemes fókuszálni, azaz: paritás helyett a komplementaritásra. ${ }^{96}$

Sutton szerint (Sutton 2010, p. 190) a kiterjedt elme körül folyó metafizikai vita miatt - hiszen a kognitív folyamatok konstitúciójáról, tágabb értelemben ontológiájáról van szó könnyen háttérbe szorul az elmélet valódi ambíciója. Clark az általa propagált biotechnológiai

\footnotetext{
${ }^{96}$ Erről hosszabban lásd az „Érzékszervi helyettesítés” alfejezetet.
} 
elme tudományának - mely interdiszciplinaritásának mértékét tekintve még a kognitív tudományt is meghaladja, ugyanis magában kell foglalja a társadalomtudományokat is, amint azt később látni fogjuk - legfontosabb feladatának azt tartja, hogy feltárja és megvizsgálja „a különböző módokat, ahogy a nem-biológiai állványzatok [scaffolding] augmentálják (vagy gátolják) a [értsd: kognitív] teljesítményt” (Clark 2002a, p. 29).

Kissé bővebben máshol így ír:

„A nagy része annak, ami számít az emberi intelligenciát illetően nem az agyban bújik meg, sem a technológiában, hanem a komplex és iterált interakciókban és együttmüködésekben a kettő között... Ezen interakció-terek tanulmányozása nem könnyü, és egyszerre múlik új multidiszciplináris szövetségeken és a modellezés, valamint az analízis új módjain. A nyereség azonban látványos lehet: nem kevesebb, mint egy újfajta kognitív tudományos együttmüködés, mely nagyjából egyforma mértékben foglalja magában az idegtudományt, fiziológiát, valamint a szociális, kulturális és technológiai kutatásokat" (Clark 2001, p. 154. Idézi Sutton 2010, p. 191).

A szakirodalomban bevett szokássá vált a kiterjedt elme „első és második hullámáról” beszélni (Menary 2010b). Az első hullám a paritás elve köré összpontosul, és amint az remélhetőleg itt is láthatóvá vált, elsősorban a hipotézis metafizikai vonalát vizsgálja. Amennyiben egy externális elem úgy funkcionál, mint egy internális, akkor azt a kiterjedt rendszer elemének tekinthetjük, és kognitívnak minősül. Itt tehát a kulcsfogalom a (funkcionális) hasonlóság; Otto notesze a „B” kritériumok révén a lehető legjobban hasonlítani próbál Inga biológiai elméjére.

A második hullám kulcsfogalma ezzel szemben a komplementaritás. Az externális elemnek nem kell imitálnia semmilyen szinten az internálist ahhoz, hogy kognitívnak számíthasson (e státusz az integráción fog múlni, erről részletesen lásd például Rowlands 2010b). És bár a kritikusok legnagyobb része az első hullámra és a paritási elvre összpontosít, a kiterjedt elme védelmezői jellemzően inkább a második hullámát tartják szem előtt, a paritási elvet pedig csupán intuíciós segédeszközként tartják hasznosnak. A két megközelítésmód között egyébként maga Clark is érezte a feszültséget (Clark 1998, p. 99), és bár ezek explicit módon nem mondanak egymásnak ellent, Sutton (2010) arra hívja fel a fígyelmet, hogy az első hullám legalábbis eltereli a fígyelmet az externális elemek (ő exogramoknak hívja őket) individuális különbségeiről, illetve ezen eltéréseket kvázi nem kívánatos színben tünteti fel. 
„Röviden, a paritási elv elmulasztja motiválni a partikuláris externális szimbólumrendszerek egyéni és egyedi tulajdonságainak kutatását, vagy ama partikuláris módokét, ahogy ezek kapcsolódási felületeket [interface] alkotnak” (Sutton 2010, p. 200).

Így, még ha a kiterjedt elme első hulláma nem is kifejezetten téves, legalábbis hiányos. Állsápontom szerint a legcélravezetőbb a paritási kitételt elégséges, de nem szükséges feltételnek felfogni, ami a karteziánus intuíciókat kezdi ki. Amikor pedig a biosovinisztikus előítéletek meglazultak, a második hullám gondolkodásmódja szerint a különböző externális szimbólumrendszerek és az ezekkel való szoros interakcióink vizsgálata révén teljesebb képet alkothatunk a kognícióról. A komplementaritási elvet a következőképp ragadhatjuk meg:

„Az agynak nem kell időt pazarolnia ilyen képességek utánzására. Inkább meg kell tanulnia interfészeket alkotnia externális médiumokkal olyan módokon, hogy maximálisan kihasználhassa ezek partikuláris erényeit” (Clark 1997, p. 220).

Látható tehát a kiterjedt elme második hullámának motivációja, mely élesen elkülöníti az elsőtől. A paritási és komplementaritási különbségen túl azonban nincs semmilyen különbség az ilyen rendszerek tekintetében. Ahogy például Bach-y-Rita és mtsai. (2003 p. 286) is megkülönböztet ${ }^{97}$ augmentatív és szubsztitutív rendszereket, ezt megtehetjük mi is - azonban ez a besorolás mit sem változtat azon, hogy az ezek alapján értelmezett externális részek a kognitív rendszer konstitutív elemei.

Van azonban a kiterjedt elmének egy, a szakirodalomban kevésbé kifejtett harmadik hulláma is, melynek összekapcsolódott rendszerei már jelentős mértékben különböznek az eddigiektől. A továbbiakban ebben az irányba indulunk el.

\section{Másfajta kiterjedések}

\subsection{Javaslat egy módosításra}

A kognitív összekapcsolódás „A” kritériumai következők voltak:

\footnotetext{
${ }^{97}$ Lásd az „Érzékszervi helyettesítés” alfejezetet.
} 
(1) Az (internális és externális) elemek között kétirányú interakció áll fenn.

(2) Minden elem aktív okságilag.

(3) A rendszer együtt úgy irányítja a viselkedést, ahogy a kogníció általában.

(4) Ha kivesszük az externális elemet, csökken az alany kompetenciája, mintha egy agyrészét operáltuk volna ki.

Ezek a kritériumok plauzibilisnek tűnnek Otto és notesze esetén, különösen azután, hogy az intuíciókat jobban megnyugtató „,B” kritériumok is játékba kerülnek, melyek szorosabbra füzik a hasonlóságot Inga biológiai agyával. Csakhogy a „B” kritériumok nem lehetnek a kogníció kritériumai is, amint azt korábban láthattuk. Ahogy a paritási elv is legfeljebb elégséges feltételét jelentheti a kogníciónak: valójában nem kell elvárnunk az externális folyamatoktól, hogy funkcionálisan túl szigorú értelemben hasonlítsanak az internálisokra. A paritási elv ilyen szigorú értelmezését elvetettük. Egy aspektusát azonban érdemes érvényben tartani, mégpedig, hogy az externális és internális folyamatokat a lokációtól függetlenül kell megítélni. ${ }^{98}$

Számomra (4) tünik problematikusnak. Az világos, hogy Otto és a hozzá hasonló esetekben az externális elem sérülése, elvesztése a kognitív kapacitás csökkenésével jár. És általában elmondható az is, hogy a kiterjedt elme szakirodalma föleg fizikai dolgokkal összekapcsolódó hibrid rendszerekkel foglalkozik, hiszen nem sok értelme volna összekapcsolódást keresni olyan eszközökkel, melyek rontják a teljesítményt. ${ }^{99}$ Csakhogy ez igazságtalanul sokat vár el az externális elemtől.

Az internális kognitív világban ugyanis nincs ilyen szerencsénk. Nem mondhatjuk, hogy csak olyan internális folyamatok léteznek, amelyek növelik a rendszer kompetenciáját, és egy folyamat bizonyára nem szünik meg kognitívnak lenni pusztán azért, mert a rendszer egészének teljesítményét nem növeli valamilyen módon. Ráadásul nem csak neutrális, de negatív hatású kognitív folyamatok is léteznek, melyek valamilyen módon csökkentik a rendszer kompetenciáját.

Vegyük például az „Elfogadhatatlan én-kép” alfejezetben említett csúcsérték-végső érték szabályt. Az emlékek célja (legalábbis így támaszkodunk rájuk), hogy a korábbi tapasztalataink alapján keressük a számunkra jó élményeket és kerüljük a rosszakat. Csakhogy e kognitív hatás miatt két rossz élmény közül hajlamosak vagyunk a rosszabbat választani, pusztán mert a korábban átélt élmény legvége kevésbé volt kellemetlen, mint

\footnotetext{
${ }^{98}$ Lásd még: marslakó-intuíció a „Kognitív felfúvódás, csúszós lejtő és a határtalan elme” alfejezetben.

99 Természetesen ilyen irányú kérdések is felvethetőek. Például: az alkohol tekinthető a felejtés kiterjedt rendszere externális elemének?
} 
előtte, és így emlékezetünk pozitívabbként tárolta el. Ez a rendszer egészét kiszámíthatóan rossz döntésekhez vezeti, mely ily módon nem képes az érdekeit követni.

Vagy vegyük a már szintén érintett Florida-hatást, mely az elöfeszités egy fajtája (Bargh és mtsai. 1996). Alanyok szavakkal kapcsolatos feladatokat végeznek el: az egyik csoport számára nincs összefüggés a szavak közt, a másiknak azonban van egy szó, amelyik összekapcsol néhány más szót is, mégpedig az „öregség.” Maga az „öregség” szó nem szerepel a szavak között, de olyanok igen, mint amilyen a „ránc”, a „feledékeny”, stb. Az alanyoknak fel sem tünik, hogy az „öregség” szóval kapcsolatos szavak is voltak a szavak között, melyekkel a feladatokat végezték. A lényeg ezután következik: az alanyokat megkérik, hogy menjenek át egy másik terembe egy másik feladatot elvégezni. A kísérletvezetők azonban valójában azt nézik, hogy milyen tempóban mennek át egyik teremből a másikba. Az „öregséggel” kapcsolatos szavakkal dolgozó csoport lényegesen lassabban halad. Ez a tudattalan előfeszítési hatás, ha nem is kifejezetten káros (legalábbis ebben a helyzetben), az azonban bizonyos, hogy nem növeli a viselkedési kompetenciát. Mindenesetre abban nem sokan kételkednének, hogy itt egy kognitív jelenségről van szó. Sok egyéb példát is lehetne hozni, például a biológiai memória megbízhatatlanságára, a konfabulációra, a szuggesztióra való fogékonyságunkra vagy pszichológiai heurisztikákra, de ezektől most eltekintünk.

Az azonban világos, hogy a mentális folyamatokat nem az alapján kategorizáljuk kognitívnak, hogy növelik-e a rendszer kompetenciáját, és emiatt az externális elemekre vagy a kiterjedt rendszerekre sem alkalmazzuk jogosan ezt a kritériumot. Ezért javaslom (4) átalakítását a következő módon:

(4b) Ha megváltoztatjuk az externális elemet, megváltozik az alany kompetenciája, mint ha egy agyrészét változtattuk volna meg.

Ugyanakkor azt is érdemes fígyelembe venni, hogy szigorú értelemben nem biztos, hogy ezek a hatások csak a kompetenciára érvényesek. Ha egy vizsga előtt sikeres embereket ábrázoló képeket látok, akkor a vizsgám nagy eséllyel sikeresebb lesz, mint ha nem néztem volna efféle képeket; ha pedig egy kisebbséget sztereotipikusan (és tévesen) rosszabbnak szokás tartani valamilyen téren (például a lányokat matematikából, a feketéket általános intelligenciából), és erre a vizsga előtt emlékeztetik őket, akkor rosszabban fognak teljesíteni. Ha ellenben nem emlékeztetik őket erre, akkor nem teljesítenek rosszabbul. Ám pusztán egy vélt vagy valós szemlélő szerepeltetése is elegendő az alany kompetenciájának 
megváltozásához, amint azt Triplett (1898) demonstrálja. ${ }^{100}$ Az ehhez hasonló helyzeteket az eredeti összekapcsolódási kritériumok alapján akár értelmezhetjük egy kiterjedt rendszernek is. Ha valaki mondjuk állandóan hordoz egy olyan tárgyat, mely a megfelelő asszociációkat idézi fel számára, akkor a külső és belső tényezők együttesen fogják meghatározni a kogníciót.

De nem minden kognitív hatás vagy változás foglal magában a kompetenciára vonatkozó változást. Egy moziteremben, ahol elterjed a nevetés vagy az ásítás, én is nagyobb eséllyel fogok nevetni vagy ásítani - ennek azonban a kompetenciához csak igen mesterkélt közegben lehet köze. Így a kritérium végső változatának inkább a viselkedésre kell vonatkoznia, melynek része a kompetencia is, de tágabb annál, hiszen a viselkedés lehet kompetens és kompetencia-neutrális is.

(4c) Ha megváltoztatjuk az externális elemet, megváltozik az alany viselkedése, mintha egy agyrészét változtattuk volna meg.

Ha Otto noteszében megváltoztatjuk a címet, ugyanolyan kompetens módon, de máshova fog menni; ha összefirkáljuk az egész noteszt, a kompetenciája, hogy odajusson bizonyos helyekre, csökkenni fog; ha pedig beleírunk egy viccet, nevetni fog, aminek a kompetenciához nincs köze, a viselkedéséhez azonban igen.

Hogy az intuíciók számára elfogadhatóbb legyen, ez utóbbit gondoljuk el inkább a következő módon: a noteszt egy jópofa barátjától kapta, így akárhányszor csak előveszi, mindig jókedvre derül. A jókedvnek megvannak a maga pozitív és negatív kognitív hatásai. Jókedvüen kreatívabbak vagyunk, de kevésbé kritikusak; a rosszkedv pedig az analitikus gondolkodásra van jótékony hatással (Jung és mtsai. 2014). Hogy ezek a hatások milyenek is pontosan, az a példa szempontjából mindegy. A fontos, hogy Otto minél rendszeresebben használja a noteszt, a hatások annál inkább érvényesülnek, és valóban ahhoz lesz hasonló, mint ha a hormonrendszerébe nyúltunk volna bele, ezáltal pedig tartós kognitív változásokat eredményeztünk volna.

Mi értelme e változtatásoknak? Egyrészt a kritérium így jobban összhangban áll Clark és Chalmers eredeti intenciójával, mely szerint az internális és externális elemeket ugyanazon szempontrendszer szerint kell vizsgálni. Másrészt a kiterjedt elme kerete így egy egész sor

100 A „társas serkentés” vagy „,szociális facilitáció” néven elterjedt jelenség lényege, hogy a rutinfeladatok elvégzésében jobbak vagyunk, ha mások is figyelnek, mintha egyedül; ugyanakkor komplexebb feladatok elvégzése során mások jelenléte rontja a kompetenciát (Zajonc 1965). Ebből is látszik, hogy a kompetencia nem választható le a szituációról, amelyben megjelenik, nem „intrinzikus”. 
jelenséget tesz kezelhetővé, amire korábbi formájában nehézkesen, vagy egyáltalán nem lett volna képes. Továbbá a fígyelmet is olyan irányba tereli, amire az eredeti megközelítésben kevesebb hangsúlyt helyeztünk, és amit hiányosságként az elmélet több, második hullámhoz tartozó szövetségese is nehezményezett. Most pedig lássunk néhány példát az így kezelhetővé tett jelenségekre.

\subsection{A társas kiterjedés}

Elgondolható olyan hibrid kognitív rendszer, melyben az externális elem nem valamiféle élettelen tárgy, hanem egy másik ember elméje. Ennek Tollefsen (2006) a „kollektív elme” nevet adta. Ezáltal válik explicitté az eredeti elméletben is megbúvó lehetőség, hogy több elme is képezhessen egyetlen kognitív rendszert.

Tollefsen kifejt egy Clark és Chalmers által is említett példát: a notesztől eltérő „,más esetekben valaki hitei akár a titkárában, könyvelőjében vagy kollaborátorában testesülhetnek meg" (Clark és Chalmers 2010, p. 38). Tollefsen példája Otto és hírhedt notesze helyett az éles eszü Ingát és férjét, a szétszórt Olafot kapcsolja össze (aki éppenséggel - mit tesz a sors filozófus) egyetlen, egységes kognitív rendszerré, mely esetben Inga - ugyanazon kritériumok alapján, mint a notesz - Olaf kiterjedt memóriájaként funkcionál. Tollefsen szerint az eredeti, általa „szolipszistának” nevezett kerethez képest kevésbé támadható a kollektív elme, mert a különbözőségi ellenvetések nagy részével szemben immunis: hiszen két emberi elméröl van szó, és ezáltal nincsenek - legalábbis fundamentális - különbségek közöttük az implementáció módját és hasonlókat illetően. ${ }^{101}$ Ezzel valószínűleg lehetne vitatkozni, ugyanis még ha a két elme müködésmódja között külön-külön nincs is különbség, egy elme és két összekapcsolt elme müködésmódja között bizonyára van. Más mechanizmusok aktíválódnak, ahogy felidézek egy a biológiai agyban tárolt emléket, és mások akkor, ha megkérdezem Ingát egy fontos dátumról, majd hallom és értelmezem, amit mond. Tollefsen kollektív elméje nem jobban és nem kevésbé tartható álláspont, mint az eredeti. Hiszen ha egy kritikus számára a különbözőségi ellenvetések fontosak voltak az eredeti koncepciót illetően, akkor ebben az esetben is azok lesznek. Mindez azonban a dolgozat érvelése szempontjából irreleváns: a különbözőségi ellenvetések már eleve célt tévesztenek, így a kollektív elmék rendszereit (köztük Olafot és Ingát is) nyugodtan tarthatjuk hibrid kognitív rendszereknek.

\footnotetext{
${ }^{101}$ Lásd a különbözőségi ellenvetéseket az „Ellenvetések” alfejezetben.
} 
Tollefsen maga nem tér ki a kiterjedt kollektív elme egy másik lehetséges verziójára, melyet Gallagher és Crisafi (2009) vet fel, de feltehetően nem lenne kifogása vele szemben. Olafot és Ingát használva példaként, a következőről van szó. Olaf a filozófiai problémák megoldása (illetve, valljuk be, inkább problémák létrehozása) közben, amikor gondolkodik, belső párbeszédet folytat, melynek során a saját álláspontját egy másik állásponttal ütközteti, mintha egyedül sakkozna. De mi van akkor, ha ugyanezt a párbeszédet Ingával folytatja le? Gallagher és Crisafi a paritási elv alapján azt mondja, hogy nincs különbség a két folyamat kognitív jellegét tekintve. Hajlok arra, hogy ezt egyrészt elfogadjam, másrészt arra, hogy Tollefsen koncepciójába illeszthetőnek tartsam: itt ugyanis a problémamegoldás kollektivitásáról van szó, és ez nagyon hasonlít ahhoz, amit Tollefsen később a tranzaktív memóriáról mond. De térjünk most vissza Tollefsen gondolatmenetéhez!

Nem nehéz belátni, hogy az „Inga mint externális memória” müködhet az eredeti Clark és Chalmers-féle koncepció szerint is. A kollektív elme nóvumát és számunkra is érdekes irányát az jelenti, amikor Tollefsen a tranzaktív memória jelenségét ${ }^{102}$ vizsgálja, és igyekszik ebben a keretben felmutatni. Ennek során két ember közül egyik sem rendelkezik a felidézni kívánt információval, annak csupán töredékeivel, ellenben közösen képesek előhívni azt, így megjelenik valami új, melynek felidézésére az individuális elmék önmagukban nem lettek volna képesek. Ilyen tranzaktív memória-rendszereket a résztvevő elmék és a köztük lévő interakció alkot együttesen. Ezt a példát egyébként (paradigmatikusan idősebb házastársak esetében, „autobiografikus memóriaként”) Sutton (2010) is felveti. Ha útbaigazítást kérek valakitől az utcán, még nem alkotunk ilyen rendszert; olyan csoportok azonban igen, ahol az adott információ kódolása, tárolása és előhívása közösen zajlik.

De mi van akkor, ha az elmék interakciója révén valami drasztikusabb újdonság jelenik meg?

„Bizonyos, adott körülmények között [...] valamely embercsoportnak új, és az azt alkotó egyénektől nagyon eltérő jellemvonásai vannak. A személyiség tudata eltűnik, s az összes egyedek érzelmei és gondolatai egyugyanazon irányt vesznek. Egy kollektív lélek formálódik, átmeneti módon ugyan, de jól megkülönböztethető jellemvonásokkal. Bizonyos együttesség jön létre, amit [...] lélektani tömegnek nevezek. Ez most már egyetlen lény, és alá van vetve a tömegek lelki egységbeli törvényének” (Le Bon 2004, p. 17).

\footnotetext{
${ }^{102}$ Wegner 1986.
} 
Egy efféle lélektani tömeg egyaránt képes altruista hösöket és morális szörnyetegeket varázsolni egyébként teljesen átlagos egyénekből. De számunkra mindez vajon miért érdekes? Azért, mert a több elme interakciója révén olyasfajta csoportelme jön létre (vagy lélektatni tömeg), mely több (de legalábbis más), mint a részek összege, ami visszahat az individuális elmékre, és adott esetben olyan szélsőséges érzelmekre, gondolatokra, tettekre sarkallja őket, melyekre maguktól, külön-külön soha nem lettek volna képesek. Továbbá, ha leválasztjuk a tömeget az egyéni elméröl, visszatér minden a megszokott mederbe. ${ }^{103}$

(4c) Ha megváltoztatjuk az externális elemet, megváltozik az alany viselkedése, mint ha egy agyrészét változtattuk volna meg.

A megváltoztatott kritériummal már az efféle pszichológiai jelenségek is beleférnek a kiterjedt elme keretei közé. Lássuk, milyen hasonlóságok és különbségek vannak egy eredeti és egy efféle pszichológiai hibrid rendszer között!

Vegyünk egy éppen őrjöngő, lincselő tömeget, melybe Otto véletlenül keveredett, viszont az hatékonyan magába szippantotta, így a tömeg lelki egységének részévé vált. Otto és a tömeg között kétirányú interakció áll fenn, hiszen Otto maga is alkotja, fenntartja a tömeget, a tömeg érzelmi ingadozása pedig meghatározza Otto érzelmeit is. Ha lelki hevületében felkiált (mely hevületet az externális elem okozta), az tovább hevíti őt magát, az internális elemet és az externálisat is, tehát a körülötte állókat, így okságilag a rendszer mindkét összetevője aktív. A rendszer együtt úgy irányítja Otto viselkedését, ahogy a kogníció általában, például a vágyai határozzák meg viselkedését; csak épp a megszokottól eltérően, és a tömeg jelenléte okán ez most nem egy fagyi elfogyasztásában merül ki, hanem például egy autó felborításában. Továbbá, ha hirtelen eltủnne, lehiggadna vagy tovább hergelödne a tömeg, Otto érzelmei is ahhoz mérten alakulnának.

A szélsőséges példa miatt kevésbé tünhet fontosnak, hogy egy ilyen jelenség beilleszthetö-e a kiterjedt elme keretei közé. Csakhogy az ehhez hasonló pszichológiailag egységes vagy összekapcsolt rendszerek, még ha nem is ilyen drasztikusan, de meglehetősen gyakoriak. Mondhatni, aligha létezik olyan izolált elme, mely nem kiterjedt valamilyen

\footnotetext{
103 Wilson (2004) megkülönbözteti egymástól a szociális manifesztáció tézisét (individuumok csak akkor rendelkeznek bizonyos mentális állapotokkal, tulajdonságokkal, amikor egy bizonyos fajtájú csoporthoz tartoznak) és a kollektív vagy csoportelmét (a csoport tulajdonságai és mentális állapotai nem redukálhatók az egyének tulajdonságaira és mentális állapotaira). Hogy Le Bon esete nem fér-e bele mindkettőbe, arról legalábbis lehetne vitatkozni, mindenesetre a mi szempontunkból - vagyis annak a kérdésnek a perspekítvája felől, hogy a pszichológiai tömeg képezheti-e az externális részét a kiterjedt elmének - tulajdonképpen ennek nincs különösebb jelentősége.
} 
pszichológiai értelemben. A társas helyzetekhez még csak nem is szükséges, hogy a másik ember ténylegesen jelen legyen, elég, ha az alany feltételezi azt. ${ }^{104}$

Otto és a notesz, illetve Otto és a lélektani tömeg egyaránt tekinthető kiterjedt kognitív rendszernek, minthogy a rögzített négy kritérium szerint kapcsolódnak össze. Ugyanakkor van közöttük különbség is, amire a későbbiekben kitérünk. Előtte azonban néhány szó a csoportelméröl.

Hogy szükséges megvizsgálni a csoportban fennállló valamiféle elmét, tehát azt a valamit, ami több elme komplex interakciójának révén jön létre, és nem vezethető vissza az individuális résztvevőkre, már a 20. század elején felvetették. Ennek (illetve a pszichológiának mint tudománynak önmagában) úttörő alakja Wundt (1912/1916), aki a kísérletekkel vizsgálható individuális pszichológia mellett a történeti és kulturális kontextusokkal szintén dolgozó pszichológiát is megalapozni igyekezett, mely diszciplínát „tömeglélektannak” nevezte (Völkerpsychologie). Ez utóbbi vizsgálati tárgyát „,azon mentális produktumok alkotják, amelyeket az emberi élet közössége hoz létre, és amelyek, éppen ezért, megmagyarázhatatlanok pusztán az individuális tudatosság által, hiszen előfeltételezik többek kölcsönös tevékenységét” (Wundt, 1912/1916, p. 3).

Pléh (1990, p. 283) megfogalmzása szerint: „Wundt megengedi, hogy az elemi lelki jelenségeket visszavezethetjük a fiziológiai folyamatokra, a lelki élet, a magasabb szerveződés törvényeit illetően tagadja a visszavezethetőséget."

Wundton kívül mások ${ }^{105}$ is felvetették egy ilyen diszciplina szükségességét, például McDougall is a szociálpszichológia nem elementarista megközelítését propagálta. Ideális tárgyának a kollektív mentális élet általános elveit tartotta, „amelyeket nem lehet kikövetkeztetni az izolált individuumok mentális életének törvényeiből” (1920, p. 7).

Ezek a törekvések azonban háttérbe szorultak amiatt az igény miatt, hogy a pszichológia közeledjen a természettudományokhoz. Az általános vélekedést jól összefoglalják Allport szavai egy korabeli programadó szociálpszichológia tankönyv oldalain: „Nincs a csoportoknak olyan pszichológiája, amely lényegében és teljességében ne az individuumok pszichológiája lenne [...] A pszichológia minden ágában az individuum tudománya. Az elveinek tágabb egységekre való kiterjesztése nem más, mint az értelmének elpusztítása" (Allport, 1924, p. 4).

\footnotetext{
${ }^{104}$ Sőt, még csak nem is kell, hogy tudatosan feltételezzen ilyet. A becsületkasszás fizetési szokásainkat például jelentős mértékben befolyásolja, hogy van-e szempárt ábrázoló kép a közelben, akármilyen sematikus vagy realisztikus legyen is (Cialdini 2007). Kérdésként felmerül, hogy a szempárt ábrázoló kép és a kogitáló alany alkot-e kognitív rendszert. Múlékony volta miatt ez nem tünik túl elfogadhatónak, ugyanakkor nem vagyok benne biztos, hogy a kritériumokat végiggondolva nem kellene-e mégis annak tartanunk.

${ }^{105}$ Pl. a már említett Le Bon is 1896/1920 vagy Freud 1921.
} 
A csoportelme lehetősége a mai napig nehezen talál széles körü elfogadtatásra. A következő, „Szuperorganizmikus tendenciák és pszichológiai malter” címü alfejezetben található gondolatmenet talán mégis ennek elfogadása mellett szól, amivel elmélyíteni igyekszem azt az igényt is, hogy a kiterjedt elme rendszereit némely társas helyzetekre is kiterjesszük.

\subsubsection{Szuperorganizmikus tendenciák és pszichológiai malter}

Kesebir (2012) meggyőző módon érvel amellett, hogy az emberek szuperorganizmikus tendenciákat mutatnak: olyan a pszichológiai architektúránk, hogy képesek, sőt, megfelelő körülmények között hajlamosak vagyunk olyan csoportokba szerveződni, ahol a csoport látványosan átveszi az irányítást az individuum fölött. Mindez lehetővé teszi, hogy az ilyen jelenségeket a kiterjedt elme teóriájának keretei között értelmezzük. Ebben az alfejezetben a társas kiterjedt elme szociálpszichológiai megtámogatására teszek kísérletet. Tehát amellett érvelek, hogy a társas kiterjedt elme nem csupán konceptuális lehetőség, hanem aktuális. ${ }^{106}$ A felsorakoztatott kutatási eredmények és a szuperorganizmikus tendenciákat fejtegető gondolatmenet erősen támaszkodik Kesebir (2012) tanulmányára, tehát az alfejezet jelentős részének rekapitulációs jellege van. A dolgozat saját kontribúciójának az tekinthető, hogy párhuzamot von a szuperorganizmukus tendenciák és a társas kiterjedt elme között, és Kesebir gondolatmenetét beleszövi a kiterjedt elmére vonatkozó gondolkodásba, illetve ennek keretében próbálja meg kezelni.

Legalább két tényezőt szeretnék kifejezésre juttatni: azon konkrét felületeket és pszichológiai sajátosságokat, amelyek lehetővé, sőt, gyakorivá teszik az ilyen látványos összekapcsolódásokat; másrészt megpróbálom felmutatni, hogy az ilyen összekapcsolódások - meglehetősen kontraintuitív módon - bizonyos értelemben megelőzik az individuumot, tehát az individuum már mindig eleve ilyen összekapcsolódási hálókban létezik.

„Szuperorganizmusok” alatt a biológusok olyan fajokat értenek, ahol az egyedek fizikai különállásuktól függetlenül úgy cselekszenek, mint ha egyetlen élőlényt alkotnának (Hölldobler \& E. O. Wilson, 2009). Ilyenek például a méhek és a hangyakolóniák: szoros integráltságuk, kooperációjuk miatt tekinthetünk rájuk úgy, mint "egy emlősre, sok testben"

\footnotetext{
${ }^{106}$ Már amennyire ennek értelme van: hiszen nincsen empirikusan felmutatható, fizikai vetülete egy ilyen rendszernek. Azonban dinamikus rendszerekként lehet olyan sürü az interakció egyes elemek között, hogy érdemes így modellezni azt. Továbbá az is lehetséges, hogy a magasabb szint több, mint a részek összege, és ilyen értelemben "önállo’" léttel bir.
} 
(Tautz, 2008, p.3). A szuperorganizmikus fajok ritkán jelennek meg az evolúció színpadán, amikor azonban színre lépnek, elképesztően sikeresek. Nem nehéz belátni, hogy számbeli fölényük és szervezettségük révén miként képesek ökológiai előnyhöz jutni az individuális lényekkel, vagy olyan fajokkal szemben, amelyek rosszabbul szervezett csoportokban élnek. ${ }^{107}$ Lehengerlő sikerük mértékét több adattal is alátámaszthatjuk: az elmúlt több mint százmillió év során, mióta léteznek ultraszociális rovarok, nem tudunk olyanról, amelyik kihalt volna ${ }^{108}$ (E. O. Wilson, 1990). Jóllehet a körülbelül 900.000 ismert rovarfaj közül csupán $2 \%$-ot tesznek ki az ilyen rovarok, mégis az összes rovar testtömegének a felét alkotják. ${ }^{109}$

És hogy miként kapcsolódnak az ultraszociális rovarok az emberi elméhez? Először is, az emberi evolúciós sikerek és ökológiai dominanciánk nagyon hasonló a szuperorganizmusokéhoz, ez pedig - állításom szerint - nagyrészt abból fakad, hogy képesek vagyunk a „kaptár-tudathoz” hasonló pszichológiai csoportokat alkotni. Éppen ezért többen is amellett érvelnek, hogy az emberi faj is tulajdonképpen (részben vagy egészben) szuperorganizmus ${ }^{110}$ (Foster és Ratnieks, 2005; Stearns, 2007; D. S. Wilson és E. O. Wilson, 2007).

Kesebir (2012) sorba veszi a szuperorganizmikus szociális struktúrák létrejövésének feltételeit, majd pszichológiai eredményekkel ${ }^{111}$ alátámasztva érvel amellett, hogy ezeknek az ember is képes megfelelni: a kérdés, hogy mennyiben és mikor. Két tényezőt is fontos kiemelnünk ezzel kapcsolatban. Egyrészt nem arról van szó, hogy az emberiség állna össze

\footnotetext{
${ }^{107}$ Kesebir, 2012, p. 2.

${ }^{108}$ Mostanában persze sokat hallani a méhek küszöbön álló kihalásáról. De még ha ez meg is történik, annak is egy másik szuperorganizmikus faj lesz az oka, történetesen: mi.

${ }^{109}$ Érdekesség és a sikert alátámasztó további adat, hogy csupán a hangyák tömegét az emberiség össztömegével egyenlőnek becsülik (Hölldobler és E. O. Wilson, 2009).

110 Arról nem tisztünk dönteni, hogy az ember valóban tett-e egy „nagy lépést” [major transition] (Maynard Smith, Szathmáry (1995) evolúciója során a főemlős kolóniák felől egy szuperorganizmikus faj felé, és így biológiai értelemben annak tekinthetö-e. Mindenesetre fel lehet mutatni olyan szelekciós nyomást, mely ebbe az irányba mutat. A pleisztocén korban, amikor is a mai ember szociális jellemzői kialakultak, a csoportok közötti (szinte állandó, de legalábbis nagyon gyakori) háborúskodás (habár erröl csak meglehetősen közvetett bizonyítékok vannak, erről lásd pl.: Divale, 1972) a szuperorganizmikus tendenciákat inkább mutató, tehát jobban szervezett, jobban kooperáló csoportoknak kedvezett, amelyek képesek voltak kollektíven cselekedni (Turchin, 2006). Ez a magasabb kollektív kapacitás felhasználható volt arra, hogy más csoportoktól jussanak javakhoz és területekhez, ami pedig még több háborúhoz vezetett, ami még inkább a szuperorganizmikus csoportoknak kedvezett. A kooperációra inkább fogékony géneknek kedvezhet az ilyen evolúciós környezet, hiszen a legyőzött csoportok sokszor teljesen eltünnek a genetikai származási vonalakról (legalábbis a paternális vonalakat illetően). Pl. egy 16.-17. századi kolumbiai populáció, mely a maternális szálon több mint $90 \%$-ban dél-amerikai származású volt, addig paternális szálon 94\%-ban európai (Carvajal-Carmona és mtsai., 2000). Ezzel feltehetően Kesebir sem azt akarja mondani, hogy kizárólag vagy föleg a jobb kooperáción múlik, hogy két rivális csoport közül melyik kerül ki győztesként. A genetikai származási vonalak példája inkább azt támasztja alá, hogy amennyiben más tekintetben azonosnak tekinthető csoportok háborúskodnak, úgy a jobban kooperáló fogja továbbadni a génjeit, ezáltal pedig a jobb kooperációra való hajlamot is.

111 Mivel a szuperorganizmus kifejezetten szociális struktúra, így ennek vizsgálatakor kifejezetten a szociálpszichológiai eredményeké a kitüntetett szerep.
} 
egy ilyen szuperstruktúrává (habár elvileg ez sem lehetetlen, de erre részletesebben kitérün „A globális elme felé” alfejezetben), hanem arról, hogy az emberi egyedek univerzális képessége, hogy olyan csoportokba szerveződjenek, melyek mutatnak szuperorganizmikus jegyeket. Másrészt arról sincs szó, hogy az emberi egyedek ne mutatnának nem-szuperorganizmikus karakterjegyeket is. Kesebir hangsúlyozza: az emberi faj előnye, hogy opportunisztikusan és rugalmasan képes ilyen csoportok létrehozására. Így tehát hasonlatként nem is a hangyák vagy méhek a legmegfelelőbbek, ha az emberi szociális viselkedést szeretnénk illusztrálni (hiszen azok egyedei nem képesek önmagukban életben maradni), hanem például a nyálkagombák. Ezek az egysejtủek bőséges körülmények között individuális módon léteznek, a körülmények megváltozásával azonban a túlélés érdekében összeállnak egyetlen szuperorganizmikus egységgé; azután, ha újra beáll a bőség, megint szétszóródnak. Kesebir e hasonlatát érdemesnek látom pontosítani, ugyanis az erdőben magányosan lézengő „nemes vadember" irányába konvergáló asszociációkat juttathat eszünkbe.

Ehhez a pontosításhoz az emberi szocialitás három szintjét különböztetjük meg. Ennek legalján a vad gyerekek (feral children) találhatóak, akik a tipikus szociokulturális közeg nélkül nőttek fel, feltehetően állatok gondozásában. ${ }^{112}$ Ezek az esetek nagyon ritkák, és amint arra majd kitérünk a „Mémek és az elme” fejezetben, agyi és pszichológiai müködésükben óriási hézagok találhatóak közöttük és egy tipikus módon fejlődő emberi egyed között. Maga Kesebir sem a vad gyerekekre gondol, amikor az individuális és szuperorganizmikus állapot között oszcilláló emberi szocialitásról beszél: az individuális egyedek ezekben az esetekben már egy adott szociokulturális közegben nőttek fel, és akár több különböző csoporthoz is tartoznak. ${ }^{113} \mathrm{Ez}$ a tipikus emberi egyed szociális alapállapota, ${ }^{114}$ éppen ezért a fenti hasonlatban az ilyen egyedeket lehet megfeleltetni a nyálkagomba egysejtűinek. A különböző csoportok, melyekbe ezen egyedek tömörülnek, általában nem érik el a kohéziónak azt a

\footnotetext{
112 Candland 1993, és Newton 2002. Ezen esetek kirívósága már önmagában is utalhat arra, hogy az ember ultraszociális lény.

113 A minden fizikai adottságot tekintve jobb körülmények között, de az édesanyjuk törödése nélkül fejlödö csecsemők sokkal rosszabb mentális és fiziológiai állapotba kerülnek, mint azon társaik, akik rosszabb körülmények közt ugyan, de édesanyjuk mellett nőnek fel (Spitz 1945). Ez is az ultraszocialitásra utal.

${ }^{114}$ A „Transzformatív kognitív összekapcsolódás” c. fejezetben található kulturális különbségek fényében itt némi óvatosságra inteném az olvasót és magamat is: a csoportképzés képessége univerzális tulajdonságnak számít, viszont a szuperorganizmusságra való hajlam mértéke függhet a szocializációtól és enkultúrálódástól is. Egy kollektivista társadalom tagjai esetleg könnyebben állhatnak össze szuperorganizmikus csoporttá, mint egy individualistább társadalom egyénei. Ez azonban csupán feltételezés.
} 
szintjét, hogy szuperorganizmusnak tekinthessük öket, mely pedig a szocialitás harmadik, legmagasabb fokát jelenti. ${ }^{115}$

Ami az emberi (különböző mértékü kohéziót mutató) csoportokat a kiterjedt elmével kapcsolatban relevánssá teszik, az nem pusztán az egyedek közötti gyakori kooperáció ténye: ${ }^{116}$ opportunisztikus együttmüködés elgondolható úgy is, hogy az abban résztvevő egyedek kognitív folyamatai viszonylag érintetlenek maradnak. Ha segítek egy néninek átmenni az úttesten, létrejön egy közös/megosztott intencionalitás (shared intentionality) (Tomasello, 2009; Tomasello, Carpenter, Call, Behne, és Moll, 2005): a világ releváns aspektusát érintő, egymásnak megfeleltethető mentális állapotokkal rendelkezünk, továbbá tudatában is vagyunk ennek és a közös célnak is. Ennek keretében mindkettőnknek megvan a maga szerepe: ismerjük a sajátunkat, a másikét, és azt is tudjuk, hogy a másik is tudatában van ezeknek. ${ }^{117}$ Habár számottevő mennyiségű és komplexitású kognitív folyamat szükséges egy ilyen egyszerünek tűnő feladat végrehajtásához, azt mégse mondanánk, hogy kognitív összekapcsolódás történt, még akkor sem, ha a két egyednek a folyamatokat össze kell hangolnia. A szuperorganizmikus struktúrának szükséges, de nem elégséges feltétele a közös intencionalitásra való képesség.

Csoport alatt nem véletlenszerüen összeverődött tömeget kell érteni, vagy egy demográfiai kategória egyedeit, akik egymáshoz közel élnek. Csoportot akkor képeznek individuumok, ha az „énről” képesek „mi” nézőpontra helyezkedni: közös a szociális identitásuk, alapuljon akár a nemzetiségen, politikai párton, valláson, kedvenc focicsapaton vagy hasonlón (Kesebir, 2012, p. 8). Kulcsfontosságú továbbá, hogy az individuum az identitása részévé tegye a csoportot: hogy úgy érezze, ahhoz tartozik.

A csoportképződés, azaz az individuumok integrációja kommunikáció révén történik. Ez a kommunikáció lehet szimbolikus és nem-szimbolikus is. Előbbire a legnyilvánvalóbb példa a nyelv, mely azon túl, hogy többek között a tervezhetőséget és kooperációt teszi lehetővé, illetve azokat facilitálja egyedülálló szinten, csoporthatár-kijelölő funkciója is van (Giles, Coupland és J. Coupland, 1991). A beszédmódunkat például tudattalanul igazítjuk

\footnotetext{
${ }^{115}$ E három szint a kognitív összekapcsolódás társas fajtáinak is osztályozási paramétereiként szolgálhat: a vad gyerekek nincsenek összekapcsolva másokkal; a tipikus emberek láthatatlanul vannak összekapcsolva másokkal; a szuperorganizmusba intgrálódó egyedek pedig láthatóan.

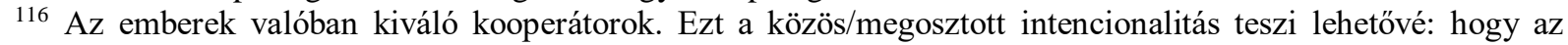
ember képes a világ ugyanazon aspektusát érintő, egymásnak megfeleltethető mentális állapotokban osztozni. Mindez egészen fiatal csecsemőknél megfígyelhető. Ez önmagában szükséges, de nem elégséges feltétele a szuperorganizmikus struktúrának.

117 Mindez a közös/megosztott fígyelem (joint attention) miatt lehetséges (Moore és Dunham, 1995), amelyet már más főemlősök is gyakorolnak, de az ember minőségileg más szinten. Ez már 9 hónapos csecsemőknél megjelenik, amikor is a baba követi a gondozó tekintetét, és maga is képes így felhívni annak fígyelmét általa figyelemre méltónak tartott dolgokra (Liszkowski, Carpenter, Henning, Striano és Tomasello, 2004).
} 
azokhoz, akikkel szimpatizálunk vagy kooperálunk (Giles és Smith, 1979), illetve ennek ellenkezője fígyelhető meg olyan esetekben, amikor identitásunkat veszélyben érezzük (Bourhis és Giles, 1977). Emellett egészen fiatal kortól kezdve megjelenik az anyanyelvi beszélők iránti preferencia ${ }^{118}$ (Bradac, 1990). Tehát a hasonló beszédmód elősegíti az egyedek egymás iránt érzett szimpátiáját, illetve az egymás iránt érzett szimpátia közelíti egymáshoz az egyedek beszédmódját.

A nyelven kívül egyéb szimbólumok is segíthetik a csoportképződést és fennmaradást, amilyenek például a közös mítoszok, zászlók, jelképek, himnuszok, hagyományok: ezek potenciájáról árulkodik, hogy képesek az individuumok identitását olyan absztrakt vagy fiktív csoportokban is lehorgonyozni, amilyenek a nemzetek, ahol valójában az egyének menthetetlenül idegenek maradnak egymás számára, mégis képesek erős szolidaritást érezni egymás iránt (Kesebir 2012, p. 11).

Ami a normativitást illeti, nincs olyan nép vagy közösségnek tekinthető csoport, amelyik ne rendelkezne közös értékeket kifejező és közvetítő népmesékkel, szólásokkal, legendákkal (Bascom, 1953), ez tehát valóban emberi univerzálénak tekinthető. Érdekes módon a pletyka is kiváló eszköz az értékközvetítésre: továbbadjuk, hogy mi számít elfogadható vagy elfogadhatatlan viselkedésnek, illetve megtudjuk általa azt is, hogy kivel érdemes kooperálni a csoportból, és kivel nem (Dunbar, 2004; Merry, 1984). Egy evolúciós perspektíva felől nézve a tetemes idő, amit pletykálással töltünk, sokkal kevésbé rejtélyes, hiszen a csoport normáinak betartását, annak kohézióját segíti elő. Akiről kiderül, hogy nem úgy viselkedett, ahogy elvárt, attól a jutalmakat megvonhatják, vagy még szigorúbban büntethetik, ez tehát a kooperáció malmára hajtja a vizet. (A normakövetési igényünkről néhány bekezdéssel később bővebben lesz szó.)

A nem-szimbolikus kommunikációt testi megnyilvánulások képezik. ${ }^{119} \mathrm{~A}$ csoportformáció szempontjából a legfontosabbak ezek közül a közösen vagy egyszerre végzett mozgások, mint amilyen a tánc vagy a menetelés. A tánc is univerzális emberi jelenség, és már az őskorban kitüntetett szerepe volt (Ehrenreich, 2006). Az ilyen összehangolt mozgásokat (és a zenét is) Freeman (1995) a csoportformáció

\footnotetext{
118 Pl. már egy öthónapos csecsemő is inkább néz az anyanyelvi beszélőre, mint olyanra, aki akcentussal vagy más nyelven beszél (Bradac 1990).

119 Kesebir az egyedek mentális állapotainak egymáshoz való igazodását ebben az esetben a tükörneuronok müködésében alapozza meg, amelyek automatikusan leképezik az agyban azokat a mozdulatsorokat, melyeket mások hajtanak végre, mégpedig éppen úgy, mintha az adott egyed hajtotta volna végre (csak épp másmilyen mértékben). Így tehát az elmék között nincs áthidalhatatlan szakadék, melyet csakis tudatos interpretációval lehet áthidalni, hanem amit az egyed lát, azt automatikusan leképezi önmagában, ezáltal pedig interpretálja is (Rizzolatti és Craighero, 2004). Szerencsére ez a problémakör nem tartozik szorosa a dolgozat gondolatmenetéhez, így nem kell állást foglalnia benne.
} 
„biotechnológiájának” nevezi, mert könnyen előidéz egy eksztatikus tudatállapotot, mely során az egyén úgy érzi, feloldódik egy nála nagyobb közösségben. Ez a hatás túlcsordul a tánc keretein is: Wiltermuth és Heath (2009) kimutatta, hogy a közös tánc, illetve általánosságban a szinkronicitás felnőttek között nagyban elősegíti a kooperáció létrejöttét. Az ilyen tevékenységek tehát a csoport létrehozásában és annak fenntartásában is fontos szerepet játszhatnak.

Az eddig említett lelki sajátosságok is okoznak már egyfajta gravitációt a csoportképzés felé, de Kesebir szerint a döntő lépést a szociális identitás kialakulása jelenti. Ekkortól az egyén már rendelkezik „tudással a szociális csoportban (...) való tagságáról, valamint az ehhez tartozó értékről és érzelmi jelentőségről” (Tajfel, 1981, p. 255). Nem pusztán arról van szó, hogy a csoport tagjai (esetleg nagyon) szimpatizálnak egymással, ezért hajlamosak kooperálni, vagy előnyben részesítik egymást más csoportok tagjaival szemben, ${ }^{120}$ hanem arról, hogy a csoport az identitásuk részévé válik. Ennek komoly következménye, hogy az egyének önmagukra vonatkozó értelmezésében a hangsúly az individuumról átkerül a kollektívára: az egyén sokkal inkább egy „szociális kategória kicserélhető példánya” lesz, semmint egyedi individuum (Turner és mtsai., 1987, p. 50). Éppen ezért a csoport tagjai nagyobb hasonlóságot látnak önmaguk és csoportjuk között, mint ami valójában fennáll, ${ }^{121}$ továbbá az idegen csoportokhoz képest nagyobb különbségeket vélnek felfedezni (Simon, Pantaleo és Mummendey, 1995).

Ha egy csoport valemely individuum identitásának részéve válik, annak valóban van egyfajta „kiterjedés” jellege, mintha a csoport része lenne az egyénnek, akár egy távolba nyújtott robotkéz, melynek érzékelői hozzánk vannak kapcsolva, és képesek vagyunk vele érezni. Például a sportdrukkerek tesztoszteronszintje megugrik vagy lezuhan, attól függően, hogy győz vagy veszít a csapatuk (Bernhardt, Dabbs, Fielden, és Lutter, 1998). Hasonló hatás érvényesül az egyének saját mentális képességeikbe vetett hitüket illetően is (Hirt, Zillman, Erickson és Kennedy, 1992), mintha ők maguk győztek vagy kaptak volna ki. Az ilyen emocionális hatások mellett kognitívak is kimutathatóak: az egyedek reakcióideje rövidebb, ha fel kell ismerniük, hogy egy adott tulajdonság jellemzö-e rájuk, ha az a csoportra is érvényes, azzal szemben, amikor a csoportra nem érvényes a tulajdonság (Smith és Henry, 1996). Mindez arra utal, hogy a selfröl és a csoportról alkotott mentális reprezentációk átfedést mutatnak, vagy teljesen összeolvadnak az egyénben.

\footnotetext{
${ }^{120}$ Habár ez is jellemző, még akkor is, ha nem számíthatnak arra, hogy a szívesség viszonzásra kerül. Pl. Diehl 1990.

${ }^{121}$ Azt, hogy „valóban fennáll”, úgy érdemes érteni, hogy „kívülállók benyomásai szerint”.
} 
Ezen szociális identitásfolyamatok a csoportképződés alapvető mechanizmusai: az említett lelki sajátosságok ösztönzöül hatnak arra, hogy a csoport egységben cselekedjen, a sokaság egyre inkább egységgé váljon a kogníciót, emóciót és viselkedést illetően is. A szerveződés e fajtája alulról felfelé történik, de a pszichológiai architektúránk nagyon simulékony a felülről lefelé történő szerveződéshez is, értve ezalatt, hogy behódolunk a tekintélynek és státusznak, amint azt Milgram (1974) megdöbbentő erővel bizonyította híres, a szóviccet kedvelők számára sokkoló kísérleteiben. ${ }^{122}$ Fontos hangsúlyozni, hogy ezt a behódolást nem a félelem vagy kényszer motiválja, hanem önkéntesen adjuk, még ha nem is mindig tudatosan vagy nem a megfelelő okokból. Sokszor a státusszimbólumok is kiváltják a behódolást.

A státusszimbólumok és hatásaik nagyon szépen illusztrálják ennek a behódolásnak a gyakoriságát és automatikus jellegét. Épp ez a sokszor drasztikus, mégis tudattalan behódolást demonstráló kutatások vetették fel a dolgozat szerzőjében a gondolkodás igényét a pszichikus egységre vonatkozó hajlamunkról, ugyanis az ilyen eredmények nehezen illeszkednek egy tradicionálisabb elmekép kereteibe. Például ha ugyanazt az előadót egy egyetemi előadás előtt három különböző titulussal mutatják be három különböző közönségnek (hallgatóként, tanársegédként és professzorként), és az előadás után megkérdezik a közönség tagjait, hogy milyen magasnak becsülik az előadót, akkor a „professzor” majdhogynem egy fejjel magasabb lesz a „hallgatónál”. A státusszimbólum ebben az esetben kihatással bír a percepcióra. Egy másik kísérletben egy olcsóbb illetve egy luxusautóval nehezítették a közlekedést, és arra voltak kíváncsiak, hogy másként viselkednek-e a soförök a két esetben az útban lévő soförrel. Az olcsóbb autóra sokkal kevesebben és később dudálnak, mint a luxusautóra (Cialdini, 1984).

A hierarchia egyfajta gerincét képezi a csoportnak, mely a munkamegosztást, kollektív döntéshozást, szociális tanulást is segíti, továbbá motiválja az egyéneket, hogy a csoport érdekében munkálkodjanak (Halevy, Chou és Galinsky, 2011). A nyilvánvaló elönyökkel szemben érdemes megjegyezni, hogy amennyiben a magasabb hierarchiai státuszt olyan személyeknek tulajdonítják, akik nem elég kompetensek, nem a csoport érdekeit tartják szem elött, vagy épp a státusztól korrumpálódnak, az az egész rendszer müködését rontja (Anderson és Brown, 2010).

\footnotetext{
${ }^{122}$ Milgram kísérletsorozata etikai okokból sem kerülhet megismétlésre, így az eredmények megbízhatósága legalábbis vita tárgya. Az etikai szempontból kevésbé problémás, néhány bekezdéssel lejjebb említett Solomon Asch kísérleti eredményeinek replikálására tett kísérletek pedig változó, kevésbé meggyőző eredményeket hoztak, így a konformitási hajlamunk mértéke nem olyan egyértelmü, mint a klasszikus eredmények mutatják.
} 
De nem csak az egyéneknek való behódolásra való hajlamunk fundamentális pszichológiai sajátosság, hanem a normakövetés is (Cialdini és Trost, 1998). A közösség által létrehozott szociális realitás, tehát szabályrendszerek, szerepek megkonstruálása, valamint az ezeknek való megfelelés igénye már fiatal gyerekkorban megjelenik (Berger és Luckmann, 1966), mint az a gyerekek játékra való éhségében is tisztán látszik, mely nagyrészt szabályokról és szerepek kiosztásáról szól. (Elég, ha a papás-mamásra gondolunk.)

A normakövetési igényünk ${ }^{123}$ és a konformitásra való törekvésünk mértékét Asch (1956) klasszikus kísérletei példázzák, sokszor a Milgram-kísérletek drasztikus eredményeit idézve. Ezekben az alanynak publikusan kell állást foglalnia olyan könnyen belátható helyzetekről, mint hogy egy egyenes három másik egyenes közül melyikkel azonos hosszúságú. Hogy ezek könnyen belátható feladatok, arról az tanúskodik, hogy amikor az alanyoknak privát módon kell dönteniük, akkor több mint 99\%-ban pontosan ítélnek. A publikus állásfoglalást az nehezíti meg, hogy a csoport többi 7-9 tagja (csoporttól függően), akik mind beépített emberek, némely esetben egyhangúan rossz eredményt mondanak. „Amíg az alanyok normális esetben a kérdéses viszonyokat szinte tökéletes pontossággal ítélték meg, a többség (értsd: beépített emberek) sikeresen terelte el a kisebbségi becslések egyharmadát a saját irányába" (Asch 1956, p. 24. Kiemelés tőlem.) Még egyszer hangsúlyozni érdemes, ${ }^{124}$ hogy de facto könnyen belátható igazságokról volt szó minden esetben.

A ,ha a többiek beugranak a kútba, akkor mi is” mentalitásan jellemző voltát egyéb kísérletek is igazolják. „A legmegbízhatóbb módja annak, hogy rávegyünk valakit, hogy tegyen meg valamit az, ha előbb rávesszük a körülötte lévőket” (Kesebir 2012, p. 24), legyen

\footnotetext{
${ }^{123}$ Hogy mennyire megsínyli az ember, amikor normát szeg meg, arra anekdotikus illusztrációként szintén Milgramhoz nyúlunk (Prinz 2006 idézi Blass 2004 alapján). Amikor a 70-es években Milgram arra kérte tanítványait egy kísérlet végett, hogy a metrón kérjenek meg idegeneket, hogy adják át a helyüket, egy diák kivételével mindenki elutasította, és az egyetlen hajlandó diák is idejekorán feladta a próbálkozást. Holott a diákot nem érte konfrontáció, sőt, a legtöbben át is adták neki a helyüket. Milgram, nem értvén a problémát, maga ment le, hogy elvégezze a kísérletet. Így számol be a tapasztalatairól:,,A szavak mintha bennrekedtek volna a légcsövemben, egyszerüen nem akartak előjönni. Visszavonulva így szidtam magam: «mégis miféle gyáva alak vagy te?» Végül több sikertelen próbálkozás után odamentem egy utashoz, és kiböktem a kérést: «Elnézést, uram, átadná a helyét?» Pillanatnyi éles, anómikus pánik lett úrrá rajtam. A férfi egyből felállt és átadta a helyét. Ekkor érkezett a második csapás. Elfoglalván a férfi helyét, elárasztott az érzés, hogy úgy kell viselkednem, amely igazolja a kérésemet. A fejem a térdeim közé ereszkedett, és éreztem, hogy elsápadok. Nem szerepet játszottam. Tényleg úgy éreztem, mint aki menten elpusztul" (Blass 2004, p. 174). Természetesen lehet némi túlzás is Milgram szavaiban, és mindenki látott már olyan valakit, aki nem így élte volna meg ugyanezt a helyzetet. De még ha nem is akarunk belehalni a normabontó viselkedésbe (mely jelen esetben tulajdonképpen annyi, hogy nem okoljuk meg, miért óhajtjuk az idegen utas helyét), az alapvető feszültség, mely ilyen esetekben jelentkezik, mégis csak ismerős, és e történet remekül illusztrálja.

${ }^{124}$ Ugyanakkor az is tény, hogy az individuális különbségeknek köszönhetően olyanok is voltak jelentős számban, akik egyáltalán nem engedtek a csoportnyomásnak. Kellemetlen érzésről azonban ők is mind beszámolnak, és ennyi tulajdonképpen nekünk már elég is, hogy a „szuperorganizmikus malter” hipotézist erősítse. Természetesen ennek nagyobb mértéke még tovább erősíti azt.
} 
szó energiatakarékosságról (Nolan, Schultz, Cialdini, Goldstein és Griskevicius, 2008) vagy arról, hogy megcsaljuk-e a párunkat (Buunk és Bakker, 1995).

Ugyanez a jelenség fígyelhető meg, amikor egy új, nyilvánvalóan hasznos találmány jelenik meg: ezek terjedése rendszerint egy S-görbe alakját veszi fel, tehát a terjedés eleinte lassú, aztán gyors, aztán megint lassú (Boutel és Lewens, 2016, 59. p). De ha a találmány nyilvánvalóan hasznos, miért nem pusztán a kommunikáció sebessége határozza meg a terjedését, azaz miért nem $r$ alakú? Henrich (2001) szerint ez a konformitási hajlammal (conformist bias) magyarázható: ez egy olyan heurisztika, ${ }^{125}$ mellyel megspórolható, hogy a versengő találmányokat, mémeket vagy kulturális variánsokat ${ }^{126}$ mélyrehatóan teszteljük, ugyanakkor a lehető legjobb opciót válasszuk, és így a nehezebb kérdést, hogy valóban hasznos-e az adott dolog, (tudattalanul is) kicseréljük a könnyebbre, azaz arra, hogy sokan használják-e körülöttünk. ${ }^{127}$

Eddig nagyjából azokat a hatásokat említettük, amelyek miatt az individuum sokszor emocionálisan, kognitívan és viselkedését tekintve is (sokszor észrevétlenül) a csoport felé csúszik. A szocialitás terének ezek szerint megvannak a gravitációs pontjai és görbületei, melyek hol jobban, hol kevésbé vonzzák az individuumokat és ,görbitik” azok mentális folyamatait. Most nézzük meg, hogy amennyiben már létrejöttek, mi tartja egyben ezeket a csoportokat, illetve milyen külső és belső mechanizmusok nehezítik szétesésüket.

Ami az individuum szemszögéből külsődleges hatás (amennyiben nem-konform módon viselkedik a többséggel szemben) az, hogy ellenszenvvel viseltetnek-e iránta vagy kirekesztik (Bassili és Provencal, 1988; Levine, 1989). A különböző gazdasági vetülettel is rendelkező játékokban az emberek akkor is szeretik megbüntetni a dezertőröket, ha emiatt fizetniük kell (Henrich és mtsai., 2006). Sőt, az ilyen altruisztikus büntetés az agy azon részeit stimulálja, amelyik a jutalmazással áll összefüggésben, tehát ez jól is esik azoknak, akik büntetnek (de Quervain és mtsai., 2004).

Ami a belső mechanizmusokat illeti, az olyan helyzetekben, ahol publikusan kell képviselni az igazunkat a többség ellentétes véleményével szemben (amilyenek pl. Asch klasszikus kísérletei is voltak), az agy azon részei aktiválódnak, amelyek a negatív érzésekkel

\footnotetext{
${ }^{125}$ A heurisztikákról lásd Kahneman \& Tversky (1982) mérföldkő jelentőségủ munkáját.

126 A mémekről és kulturális variánsokról (illetve ezek különbségeiről) később, a "Kultúra és a mémek autonómiája" c. alfejezetben lesz szó.

${ }^{127}$ A szociális aszimmetria is befolyásolja a találmányok terjedését, mégpedig elsősorban a presztízs. A presztízs nem egyenlő a dominanciával: előbbi nem kényszeríthető ki, hanem önként adjuk a kompetencia és szakértelem függvényében. A kulturális variánsok terjedése részben a ,presztizs elöitélettel” magyarázható. A konformitási előítélethez hasonlóan (gondoljunk az S-görbére), a kulturális variánsok terjedését a nagy presztizsủ egyének is befolyásolják, öket utánozzuk. „Könnyebb azt tudni, hogy ki a sikeres, mint azt, hogy mitöl” (Henrich és GilWhite 2001).
} 
állnak kapcsolatban. Berns és mtsai. (2005) és Asch (1956) is számot adnak a jelentkező különböző negatív érzésekröl; azon alanyok is beszámoltak kellemetlenségről, akik egyébként megőrizték ítéletük függetlenségét a csoportnyomás ellenére is. De a nonkonformitás, illetve az ebből eredő kiközösítés ennél drasztikusabb hatással is bír: azon agyterületek is aktiválódnak, amelyek a fizikai fájdalom során. A szociális fájdalom semmivel sem kevésbé jelentős, reális vagy kínzó fájdalom, mint a fizikai (Lieberman és Eisenberger, 2009; Eisenberger, Lieberman és Williams, 2003). ${ }^{128}$

„Az izoláció fájdalma ugyanúgy fejlődött, mint bármely más fájdalom. Csakugyan, most már jelentős bizonyíték áll rendelkezésre, hogy a szociális izoláció és az (...) ezzel járó fájdalom gyümölcsözően fogható fel mint biológiai konstruktum, olyan állapotként, amely averzív jelzésként motiválja a viselkedés megváltoztatását, hogy segítsen az egyedeknek elkerülni a sérülést és támogassa a génjeik átvitelét a génállományba" (Cacioppo és mtsai. 2011, p. 22).

$\mathrm{Az}$ is a csoportok malmára hajtja a vizet az egyénnel szemben, hogy az egyén önértékelése erősen függ attól, hogy milyen a szociális státusza az adott csoportban (Leary, Tambor, Terdal és Downs, 1995). Fessler és Haley, 2003; Haidt, 2003; Tangney, Stuewig és Mashek, 2007 is mind azt támasztja alá, hogy a kooperáció belső jutalommal, a nemkooperálás belső büntetéssel jár.

Összefoglalva: pozitív érzelmekkel jutalmaz a csoporthoz való tartozás és a csoporttagokkal való kooperáció, azok jó szociális megítélése; ezzel szemben negatív érzelmekkel büntet a csoporttal szembeni nonkonform vagy dezertáló viselkedés, mind külső (a többiek büntetése) mind belső (a kellemetlen érzések neurális alapjai) mechanizmusokkal. Így tehát az individuum szintjén és a csoport szintjén is léteznek olyan mechanizmusok, amelyek az „összetapadást” támogatják és a „szétesést” büntetik. A pszichológiai architektúránk része a malter, mely másokkal akar összetapadni. Egy másik metaforával élve: a mentális folyamatok tere görbül a csoportok felé.

A társas kiterjedt elme koncepciójához tulajdonképpen már ezek a lelki sajátosságok is elegendőek, de menjünk még tovább. A csoportok képesek a kooperáció egy olyan fokát is elérni, ahol az individuális érdek teljesen feloldódik a kollektíváéban így az egy szuperorganizmushoz válik hasonlóvá. Az erre való képesség és az ilyen kirívó esetek még jobban rávilágítanak, hogy az elmét miért érdemes olykor, legalább e szélsőséges esetekben

\footnotetext{
${ }^{128}$ Vajon milyen mértékben vagyunk szabadok kilépni egy csoportból, ha ezért pl. eltörik a karunkat? Az ezzel járó szociális fájdalom nem biztos, hogy kevésbé fájdalmas.
} 
társas értelemben kiterjedtnek tekinteni. Ilyenkor ugyanis a külső elem szinte teljesen átveszi az uralmat a belső felett.

Kesebir amellett érvel, hogy az ember is tekinthető szuperorganizmusnak, legalábbis adott körülmények között a lelki sajátosságok miatt mutat ilyen tendenciákat. A szuperorganizmusok lényegi tulajdonságai a következők: ${ }^{129}$

(1) az alacsonyabb szintủ egységek integrációja kommunikáció révén

(2) a cselekvés egységessége

(3) variáció alacsony örökölhetőségi szintje a szuperorganizmus egységei közt

(4) közös sors ${ }^{130}$

(5) az érdekkülönbségek feloldására való mechanizmusok a kollektíva érdekében.

Kesebir számomra meggyőző módon mutatja be, hogy mind az öt kitétel teljesül bizonyos mértékben az emberek esetében is, megfelelő körülmények között. Ezek müködését és teljesülését a vallás és moralitás példáin keresztül elemzi, melyek képesek elősegíteni szuperorganizmikus struktúrák létrejövetelét. Ennek rekapitulációjától eltekintünk, azonban szemügyre veszünk egy talán még ezeknél is feltünőbb esetet, mely során az egyszerü csoport szuperorganizmikus összeugrást mutat: mégpedig a csoportra leselkedő külső (vélt vagy valós) fenyegetést. Ebben az esetben válik a korábban említett nyálkagomba példája kifejezetten megvilágító erejüvé, melynek egysejtüi a túlélés érdekében szuperorganizmussá állnak össze.

Azt a belátást, hogy a csoportra leselkedő veszély ${ }^{131}$ megnöveli annak kohézióját, több kutatás is alátámasztja (pl.: Branscombe, Ellemers, Spears és Doosje, 1999; Brewer és Campbell, 1976). E kohézió a fentebb már részben érintett csoportképződési és -müködési mechanizmusok felerösödéseként érhető tetten (amilyen például a csoporttagokkal kapcsolatos elfogult gondolkodás, csoporton kívüli emberekkel szembeni diszkrimináció, a csoport normáival konform viselkedésre való hajlam, stb.). Mindezek legszembeötlőbben háború idején nyilvánulnak meg, tehát ,a háború képviseli az emberi szuperorganizmikus potenciál csúcsát” (Kesebir 2012, p. 40). Hogy krízis esetén a csoportba vagy szuperorganizmusba való „összeugrás” ne fulladjon káoszba, és a kollektíva képes legyen egységben cselekedni, többek között a vezetők ilyen esetekben jellemző kiugró

\footnotetext{
${ }^{129}$ Kesebir 2012, 8. p

${ }^{130}$ Itt olyan egyszerü dologra kell gondolni, mint hogy a hangyaboly individuális hangyáinak sorsa megegyezik a bolyéval: nem élhetnek nélküle.

131 A fenyegetésnek még csak nem is kell közvetlenül fizikainak lennie, mint háború idején, lehet pszichológiai vagy szimbolikus is. Pl.: fenyegetést jelenthet a csoport presztizsének megingása vagy valamely hitükkel szembeni kihivás megjelenése.
} 
támogatottsága segíti elő. Az emberek szinte egy emberként sorakoznak fel vezetőik mögé. ${ }^{132}$ Például az Egyesült Államokat érő 2001. szeptember 11-i terrortámadás után Bush korábban $51 \%$-os támogatottsága $90 \%$-ra ugrott. ${ }^{133}$

Hogy az egyén érdekei milyen drasztikus mértékben képesek alárendelődni a kollektíváénak, annak legékesebb példái az öngyilkos merénylők. ${ }^{134}$ McCauley (2007) arra mutat rá, hogy ezek az egyének, habár pontosan tudják, hogy meg fognak halni, és ennek ellenére hajtják végre küldetésüket, általában nem szenvednek semmilyen mentális zavartól, és nem is a kétségbeesés hajtja őket. Sőt, úgy tűnik, hogy az ilyen önfeláldozás belső jutalommal és elégedttségérzéssel jár, amint azt Oliver és Steinberg jegyzi meg. „Ezek a férfiak tudták, hogy meg fognak halni... Ugyanakkor az az érzésünk, hogy az élet sosem tủnt jobbnak számukra - ilyen elsöprő erejünek, ilyen élénknek, ilyen értelemmel telinek" (Oliver és Steinberg 2006, p. 118).

A biztos haláltól egy lépéssel távolabb az egyén életét kockáztató bajtársias tetteket találjuk, melynek megélt tapasztalatát a filozófus Glenn Gray szavaival foglalhatjuk össze, aki maga is harcolt a második világháborúban.

„Egy ilyen áldozat nehéznek és hősiesnek látszik azok számára, akik sosem éreztek közösségi eksztázist. Valójában közel sem olyan nehéz, mint sok kevésbé abszolút tett békeidőben és a civil életben, mert a halál részben irreálissá és hihetetlenné válik azok számára, akik megosztják az életüket a társaikkal” (Gray 1959, p. 46. Idézi Kesebir 2012, p. 40).

Az egyén tehát nemcsak képes feláldozni magát a csoportjáért, de ezt sok esetben könnyedséggel, gondolkodás nélkül teszi, és ez belső jutalommal is jár. (Vagy büntetéssel, ha épp elmulasztja: például bủntudat azokban, akik valamilyen rajtuk kívülálló okból nem harcolhatnak a bajtársaik oldalán.) A szuperorganizmikus jelleg tehát kimutatható, legalábbis a csoport egyéneiben bizonyos körülmények közepette olyan lelki mechanizmusok lépnek müködésbe, amelyek felerősítik a kooperációra való hajlamot, és gyengítik a dezertálásét. De vajon van-e maximális határa annak, hogy mekkora lehet egy szuperoganizmikus jegyeket mutató csoport? Például az egész emberiség képes lehet-e összeállni egy ilyen struktúrává?

Az egymással vetélkedő, ellenséges csoportok közötti feszültség és ellenségeskedés csökken, amikor a csoportok számára egyaránt értékes cél elérhetetlen pusztán egyetlen

\footnotetext{
${ }^{132}$ Ezt rally around the flag reflexnek is nevezik: Lee, 1977.

${ }^{133}$ Kesebir 2012, p. 40.

${ }^{134}$ A zelótáktól kezdve a kamikaze pilótákon át sok ilyet ismerünk a történelemből.
} 
csoport erőfeszítései árán, és ezért kénytelenek együttműködni ${ }^{135}$ (Sherif és mtsai. 1954/1961, Sherif és Sherif 1965). A magasabbrendü célokért való közös küzdelem során meglehetősen éles a váltás: „A változás, mely a viselkedésben és a csoportok közti interakció mintáiban állt be, minden megfígyelő számára megdöbbentő volt” (Sherif és mtsai. 1954/61, p. 131). Egyetlen ilyen magasabb rendủ cél elérése kooperáció révén még nem szünteti meg a csoporthatárokat, az agressziókat és a feszültségeket, de a magasabb rendü célok sorozata már képes erre.

Ugyanakkor valószínűleg a „közös ellenség” a legerősebb katalizátora egy ilyen szerveződésnek. Kesebir is felveti dolgozata végén, hogy feltehetően egy bolygóközi támadás lenne a leggyorsabb útja egy globális, pszichológiai értelemben vett szuperorganizmus létrejöttének. Nem úgy tünik, mintha lenne elvi határa annak, hogy az ember maximálisan mekkora csoportot képes létrehozni, és ennélfogva a globális szuperorganizmus egy eddig soha nem aktualizált, mégis genuin lehetőség. Mindez számunkra abból a szempontból is érdekes, hogy amikor a későbbiekben a klasszikus kiterjedt elme hipotézist próbáljuk maximálisan végiggondolni, tehát az elképzelhető legnagyobb kognitív rendszert vizsgáljuk, akkor annak lesznek (vagy lehetnek) szociálpszichológiai alapjai és motivációi is. ${ }^{136}$

\subsubsection{A társas kiterjedt elme gerince}

A fenti lelki sajátosságok lehetővé teszik az emberi csoportok szuperorganizmikus felfogását, és ez további motivációt jelent arra is, hogy a kiterjedt elme keretei közt megpróbáljuk elhelyezni. Meglátásom szerint a csoport és egyén interakcióját a legtöbb fent említett esetben tekinthetjük olyan kiterjedt kognitív rendszernek, melynek gerincét a kognitív összekapcsolódás általunk némiképp átalakított kritériumai alkotják. E szerint egy rendszer akkor tekinthető kognitívnak, ha:

(1) Az (internális és externális) elemek között kétirányú interakció áll fenn.

(2) Minden elem aktív okságilag.

(3) A rendszer együtt úgy irányítja a viselkedést, ahogy a kogníció általában.

\footnotetext{
${ }^{135}$ A pusztán fizikai közelség a csoportok számára élvezetes tevékenység közben (pl. egy film megnézése során) nem elegendő a csoportok közti feszültség csökkentéséhez, ezek csak lehetőséget biztosítanak a feszültség megnyilvánulásaihoz. Csak érdekességként érdemes említeni, hogy a csoportok közti feszültség csökkentésére szinte teljesen alkalmatlan (de legalábbis meglehetősen korlátolt hatású) eszköznek bizonyul az, ha a diszkriminált másik csoportról az elóítéletekkel ellentétes információkat közlünk velük.

${ }^{136}$ Lásd „A globális elme felé” fejezetet.
} 
(4c) Ha megváltoztatjuk az externális elemet, megváltozik az alany viselkedése, mintha egy agyrészét változtattuk volna meg.

Ezek a rendszerek aszimmetriájukban is különböznek Clark és Chalmers eredeti rendszereitől: a viselkedés szabályozásában a hangsúly sokkal inkább az externális elemen van, így tehát a kintről befele terjedés metaforája ragadja meg jobban.

Ugyanakkor vannak olyan jelenségek is, amelyekre nem teljesül minden kritérium, holott - véleményem szerint - érdemes lenne így megragadni őket. Azon esetekre gondolok, amikor az externális elem hatással van az internálisra; fordítva azonban ez nem érvényes, tehát a kétirányú oksági viszony nem valósul meg. Ilyen esetre példa, amikor a focicsapat győzelme vagy veresége hatással van a szurkoló kognitív háztartására, aki otthonról nézte a meccset, így semmilyen hatása nincs az externális elemre, nem játszik oksági szerepet. ${ }^{137}$ Azért lenne érdemes egy rendszerként kezelni az ilyen helyzeteket is, mert az egyének tapasztalata maga is ezt támasztja alá: olyan, mintha velünk magunkkal történne, ami az externális elemmel történik. (Ha a focicsapat példától ódzkodunk, akkor gondoljunk arra, amikor valamely szerettünkkel történik valami rossz vagy jó dolog, és úgy érezzük, mintha velünk történne.) De amint láttuk, nem kell a személyes tapasztalatra hagyatkozni, ez ugyanis egyénenként különbözhet: a fontos, hogy kimutatható módon olyan hatása van ezen externális elemet érő eseményeknek az internális elemre is, mintha őt magát érték volna.

E megfontolások alapján azt javaslom, hogy a társas kiterjedt elme kognitív összekapcsolódásának gerincét ne (csak) a fenti kritériumok alkossák, amelyek inkább elégséges feltételeknek bizonyulnak, hanem a Kesebir (2012) által is hangsúlyozott szociális identitás folyamatai. Anélkül, hogy e folyamatokat konkrétan megneveznénk, számunkra elegendő, hogy e folyamatok azok, amelyek elérik, hogy az egyén az adott csoport tagjának érezze magát, s hogy képes legyen az „én” nézőpontról a „mi” nézőpontra helyezkedni. Úgy gondolom, hogy ez a szükséges feltétele a társas kiterjedt elme kognitív rendszereinek. Most pedig ejtsünk néhány szót a klasszikus és társas kiterjedt elmék viszonyáról!

A két kognitív összekapcsolódás nem feltétlenül jár együtt. Esetleges biológiai és pszichológiai tény, hogy ultraszociális lények vagyunk, és emiatt a kognitív folyamatainkat mélyen meghatározzák a szociális helyzetek, hogy a kogníciónk extrinzikus, hogy az internális algoritmusokat „meggörbíti” a szocialitás tere, mely a csoportok felé lejt az

\footnotetext{
${ }^{137}$ Egyébként kénytelen vagyok legalább egy lábjegyzetben feltenni a kérdést, vajon a kétirányúság jogosan szerepel-e a kritériumok közt. Ha pl. Fodor feltételezett moduljai közt nem valósul meg ilyen kétirányúság (ahogy a feltételezés szerint nem is valósul meg), az megszünteti-e ezek kognitív jellegét? Valószínűleg nem. Ez némiképp aláássa a kritériumlista használatának jogosságát, de még mindig mondhatjuk, hogy ezek elégséges, nem pedig szükséges feltételei a kiterjedt kogníciónak.
} 
individuummal szemben. Mivel azonban ilyen lények vagyunk, a társas kiterjedés már eleve mindig megvalósult számunkra. (Kivéve a vad gyerekek ritka eseteit.)

A klasszikus kognitív összekapcsolódás, a merev, kifelé történő augmentáció ezzel szemben nem mindig, hanem opportunisztikusan, alkalomszerủen valósul meg. Ez technológiai változásokkal állandósulhat is, de jelen pillanatban talán még ez a helyzet. Mindenesetre az elme mindig nyitott ilyen összekapcsolódásokra.

Elképzelhető, hogy mindkettő nem, csak az egyik kiterjedés valósulhat meg egy fajnál. Például a szintén nagyon szociális farkasoknál talán ki lehet mutatni a társas kognitív kiterjedés nyomait, de a klasszikus kiterjedést bizonyára nem; illetve a mesterséges intelligencia képes lehet a végtelenségig augmentálni saját kognitív kapacitását, anélkül, hogy a társas kiterjedés előszelét megérezné. Tehát ezek nem szükségképp járnak együtt: a társas kiterjedés vizsgálható önmagában is. Ahogy a merev összekapcsolódás során, itt is nagy hangsúlyt kap az integráció: de a kognitív összekapcsolódás alapját a szociális identitás folyamatokra kell alapozni, arra, hogy az egyén a csoport tagjának érzi magát. Ha a kapcsolat létrejött, onnantól a csoport folyamatai metafolyamatokként meghatározzák az individuális folyamatokat is (valamint az individuális folyamatok kihatással lehetnek a csoport interakcióira).

Mindezzel közel kerülünk csoportelmét érintő ontológiai kérdésekhez is, például mi jellemzi a szocialitás és individualitás viszonyát, melyik az eredendőbb, levezethetők-e egymásból, stb. Jóllehet e problémákat a jelen disszertáció keretei között nem áll módomban részletesen megvizsgálni, mégis inkább azt a sejtést vélem megerősíthetőnek, hogy valami minőségileg új jelenik meg az ilyen interakciók révén. Mindenesetre látszik, hogy a szociálpszichológia sokszor megdöbbentő eredményei olyan kihívást jelentenek a filozófia egyéb területein is, amelyek mellett nem lehet elmenni szó nélkül.

A szocialitás alapvető emberi tulajdonság, melynek jelentős kognitív aspektusai is vannak. De nem ez az egyetlen, az első és második hullámos kiterjedt elme képviselői által gyakran ignorált terület, melyet érdemes lehet e szempontból is megvizsgálni. Ahogy Kesebir írja: ${ }^{138}$

„[Az emberi egyed] csoport kultúrától való függése szuperorganizmikus tünet, ugyanis a részek létezéséhez az egészbe való funkcionális integrációját tükrözi. Ahogy egy sejt nem létezhet a testen kívül és egy méh nem létezhet a kolónián (kaptáron) kívül, az emberek nem létezhetnek

\footnotetext{
138 Többek között Donald (1991) és Hutchins (1995) alapján. E szerzők észrevételeire a jelen dolgozat is több
} helyen támaszkodik. 
értelmesen egy szimbolikus kultúrán kívül. Az emberi kogníció ehelyett eloszlik az individuális elme és a szimbolikus kultúra között abban az értelemben, hogy az emberi kognitív folyamatok erősen támaszkodnak a kulturális inputokra" (Kesebir 2012, p. 9).

A Kesebir által vizsgált csoportok a pszichológiai sajátosságok mellett mindig rendelkeznek egy kultúrával is, melyről eddig nem esett szó, holott annak is fundamentális kognitív hatásai vannak. A kultúra és elme viszonyát fogjuk tehát az eddigi keret szerint körüljárni a későbbiekben. És bár a szocialitás aligha különválasztható élesen kultúrától, a szociális és kulturális kiterjedt elmék rendszereinek különbözö kognitív összekapcsolódása mégis egy lehetséges törésvonalát jelentheti egy ilyen szétválasztásnak. Mielőtt áttérnénk azonban a kultúrára, egy kontintentális példa segítségével megpróbálom alátámasztani, hogy a társas kiterjedések milyen jelentős mértékben áthatják a mindennapjainkat és gondolkodásunkat.

\subsubsection{Egy kontinentális példa - Heidegger}

Meglehet, a le boni lincselő tömeg és a szuperorganizmus-szerü struktúrák drasztikus, esetleg (sőt, valószínűleg) veszélyes, de legalább ritka eseményeknek tűnnek. Így, ha el is fogadjuk a társas kiterjedt elme hipotézist, nem tünik kifejezetten jelentősnek, hiszen nem kell vele sokszor számolni. Úgy gondolom, hogy ez súlyos tévedés. Állandóan ilyen kognitív összekapcsolódásokban élünk, és bár ezek legtöbbször láthatatlanok, ez mit sem változtat az erejükön (vagy az részben épp e láthatatlanságból fakad). Hogy ezt a kijelentést egy számomra meggyőző példával is alátámasszam, egy rövid időre átmerészkedünk a kontinentális filozófiai hagyományba. Önvédelmi okokból szeretném leszögezni, hogy csupán felvetésként, lehetséges vizsgálódási irányként vázolom az alább felmutatott párhuzamot, melyet Heidegger és a társas kiterjedt elme között felfedezni vélek. ${ }^{139}$

A Lét és idő bizonyos megfontolásai miatt az elme szituált felfogásai (köztük a kiterjedt elképzeléssel) filozófiai előzményének tekinthető, mely eddig felfedetlen párhuzamokat, további inspirációt és irányokat rejthet magában (Gallagher 2009). Ennek fényében használnám a társas kiterjedt elme összekapcsolódásainak jellemzésére.

Heidegger egyik legfontosabb célkitüzése megszüntetni azt az éles karteziánus szakadékot, mely a res cogitans és res extensa közt áll fenn: nem áthidalni igyekszik e

${ }^{139}$ Hasonló szabadkozásra Gallagher és Crisafi (2009) akkor kényszerül, amikor Hegel némely gondolatát próbálják átemelni a kiterjedt elméröl való párbeszédbe. 
szakadékot, az ugyanis még egy sikeres megoldási kísérlet esetén is ugyanúgy megmaradna a szubjektum-objektum dichotómiájában, mint ha a szubjektumnak „ki kellene jutnia” a világba. (Gondoljunk Descartes szolipszista kiindulópontjára.) Ezzel szemben Heideggernél a szubjektum (heideggeri terminológiában: Dasein, jelenvalólét) mindig már eleve „kinn” van a külvilágban az intencionalitás ${ }^{140}$ révén (a tudat mindig valaminek a tudata). E szükségszerü kapcsolatnak ontológiai következménye van, mégpedig az, hogy a világ elengedhetetlen részét képezi az emberi lénynek: a jelenvalólét ontológiai szerkezetéhez tartozik a világbanbenne-lét (in-der-Welt-Sein). A világban-benne-lét nem azt jelenti, hogy „egyszerüen földrajzi értelemben el vagyunk helyezve a környezetben, hanem azt, hogy egy értelemteli világ konstituálja az egzisztenciánk egy részét” (Gallagher 2009, p. 39. Kiemelés tölem,). A kiterjedt elme hibrid rendszereiben található externális elemek konsitutív szerepe a kognícióban és a világban-benne-lét mint a jelenvalólét ontológiai szerkezetének része hasonlóképp szünteti meg a karteziánus határvonalat szubjektum és objektum között, mely hasonlóság mindenképp méltó további vizsgálódásokra. Mi azonban nem erre, hanem egy másik párhuzamra fogunk fókuszálni.

A világban-benne-lét mindig egymássallét (mit-Sein) is, tehát a jelenvalólétet a többi ember is konstituálja, ők is már eleve ontológiai szerkezetének részei. Ezt lehet kapcsolódási pontként felmutatni, mely alapján Heidegger leírása a társas kiterjedt elme legalapvetőbb, láthatatlan és mindig jelenlévő összekapcsolódásainak példájaként is felfogható, ahol az externális elem a csoport. Itt „csoport” alatt nem csupán az egyéni tulajdonságok összességét, hanem egy attól különböző minőségủ valamit kell érteni, ahol a problémát épp az adja, hogy a szociális és individuális szintek nem levezethetőek egymásból. Az alábbiakban két aspektust szeretnék kidomborítani: egyrészt, hogy miként illeszthető össze a heideggeri koncepció a társas kiterjedt elmével, másrészt, hogy a társas kiterjedt összekapcsolódások alapvető, láthatatlan és uralkodó részét képezik az emberi lénynek.

Idézzük Heideggert:

„.. a jelenvalólét mint mindennapi egymássallét mások fennhatósága alatt áll. Nem ő maga van, mások elvették a létét. Mások kénye-kedve rendelkezik a jelenvalólét mindennapi létlehetőségei felett. Ezek a mások ugyanakkor nem meghatározott mások. Ellenkezőleg: minden egyes más képviselheti őket. Ami döntő, az csak a másoknak, a jelenvalólét mint együttlét által már észrevétlenül elfogadott, fel-nem-tủnő uralma. Az ember maga is a másokhoz tartozik, és megszilárdítja hatalmukat. «A mások», akiket így nevezünk, hogy saját lényegi

\footnotetext{
${ }^{140} \mathrm{Az}$ intencionalitás problematikájában nem áll módomban e dolgozat keretei közt elmélyülni.
} 
hozzájárulásunkat elfedjük, azok, akik a mindennapi egymássallétben mindenekelött és többnyire «jelen vannak». A «ki» nem ez vagy amaz, nem mi magunk, és nem egyesek és nem valamennyiünk összege. A «ki» a neutrum, az akárki [das Man]” (Heidegger 2007, p. 153).

Az akárki fogalmát nagyrészt a jelenvalólét (deficiens) létmódjára szokás használni, de ebből a részletből is látszik, hogy nem kizárólag az. „... a Mások, a mindennapi Dasein „ki”-je a csoport, melyből nem lógok ki; a kultúrám, de nem úgy értve, mint a tagjainak összege, hanem mint egy ontológiai fenomén a saját jogán” ${ }^{141}$ (Wheeler, 2018). Hogy mi az akárki jelentősége, az a néhány sorral később következő passzusban derül ki:

„Ez az egymássallét teljesen feloldja a saját jelenvalólétét „a mások” létmódjában, éspedig úgy, hogy a mások a maguk megkülönböztethetőségében és körvonalazottságában egyre inkább eltünnek. Ebben a fel-nem-tünésben és kontúrtalanságában fejti ki az akárki a maga tulajdonképpeni diktatúráját. Úgy élvezünk és szórakozunk, ahogy akárki élvez: úgy olvasunk, úgy ítélünk irodalomról és müvészetről, ahogy akárki lát és ítél: a «nagy tömegből» is úgy vonulunk vissza azonban, ahogy akárki visszavonul: «felháborítónak» találjuk, amit akárki felháborítónak talál. A mindennapiság létmódját az akárki írja elő, aki nem valaki meghatározott, hanem mindenki, habár nem összegként az" (ibid. 154).

A társas kiterjedt elme externális eleme a csoport volt, melyhez a kognitív összekapcsolódás kritériumainak teljesülésével és a szociális identitás folyamatai révén kapcsolódunk. De vajon az akárki nem képezheti-e externális elemét, illetve nem szükségképp akárki jellege van-e a korábban vizsgált csoportoknak? A kognitív összekapcsolódáshoz, amennyiben azt úgy értjük, hogy van egy elme, mely összekapcsolódik valami hozzá képest externális elemmel, például a heideggeri akárkivel, mely azután nagy mértékben, akár „diktatórikusan” is meghatározza müködésmódját, természetesen nem olyan valami, melyhez Heidegger a nevét adná. Hiszen ő épp arról beszél, hogy a jelenvalólét már eleve mindig ilyen; nincs az akárkitől függetlenül, nincs összekapcsolódás, mely során az individuális elme „kinyúl”. E különbségben az is nyilvánvalóvá válik, hogy a kiterjedt elme eredeti koncepciója minden szándéka ellenére még mindig megmarad egyfajta karteziánus alapon: ezt az alapot igyekszik destruálni a dolgozat a társas kiterjedt elme már kifejtett koncepciójával és a később kifejtett kulturális elme transzformatív kognitív

${ }^{141}$ Heidegger ontológiája ekvivokális, vagyis különálló ontológiai státuszt biztosít különböző létezőknek. (Szemben az univokális ontológiákkal, melyekben minden, ami létezik, ugyanolyan módon létezik.) Más pl. a létmódja a jelenvalólétnek (embernek) és más a kézhezállónak (a szerszámnak), és lehet érvelni amellett, hogy az akárki is különálló ontológiai kategóriát képez. 
összekapcsolódásának elképzelésével, mely összekapcsolódások már nem opportunisztikusak, hanem állandóak. Heideggerhez és az akárkihez közelítve a társas kiterjedt elmét, azt állítom tehát, hogy nem esetlegesen és alkalomadtán jönnek létre ilyen kognitív összekapcsolódások, hanem ezek már mindig eleve léteznek (bár jöhetnek létre újak is.)

$\mathrm{Az}$, hogy az akárki írja elő, hogy miként is viselkedjünk, másként úgy is megfogalmazható, hogy úgy viselkedem, ahogy szokás viselkedni, ezt pedig mindig a szociokulturális közeg határozza meg, melybe bele vagyunk ágyazva. Az akárki láthatatlan diktatúráját a következő sorokból is kiolvashatjuk:,,Mindenekelött nem «én» «vagyok» a saját Önmagam értelmében, hanem a mások az akárki módján. (...) A jelenvalólét mindenekelőtt akárki, és többnyire az is marad” (ibid. p. 157). És: „Mindenki a másik, senki sem önmaga” (ibid. p. 155).

Ha mindebből a társas kiterjedt elme általunk kifejtett koncepciójára érvényes konzekvenciákat szeretnénk levonni, akkor a kogníció folyamataiban az externális elem általánosan jellemző és lehengerlő túlsúlyát érdemes hangsúlyozni. Erre a túlsúlyra és az akárki diktatúrájára az „Elme kint hordott része” címü fejezetben fogunk bővebben reflektálni.

Egyszerü példaként gondoljunk csak azokra a második természetünkké vált felszínes és automatikus viselkedési mintázatokra, melyek alapján adott közelségből beszélünk másokkal, attól függően, hogy mennyire intim kapcsolatban vagyunk velük; ezek a távolságok kultúránként eltérnek, és anélkül sajátítjuk el őket, hogy tudatában lennénk, vagy gondolnánk arra, hogy másként is lehetne (Wheeler, 2018 példája).

De mindez nem csak olyan felszínes dolgokra igaz, mint hogy milyen közelről beszélünk emberekkel, hanem a gondolkodás folyamataira is mély hatással lehet. A szociokulturális közeget, amelyekben a kiterjedt elme elmerül, pontosabban már mindig el van merülve, a szocialitás felől már megnéztük, a következő fejezetben pedig a kultúra felől fogunk vizsgálódni.

\subsection{A transzformatív kiterjedés - Kultúra és elme}

Egy kísérlet két csoport egeret vizsgált: az első csoport ingergazdag környezetben élt, nagy ketrecben, egy tucat másik egérrel, és a tárgyak is rendszeresen cserére kerültek, melyekkel az egerek játszhattak, és feladatokat oldhattak meg velük. A második csoport egér sztenderd laboratóriumi ketrecekben élt egyedül, ingerszegény környezetben. A legfontosabb 
eredmény az volt, hogy az ingergazdag környezetben élő egerek agykérge (cortex cerebri) megnőtt (Rosenzweig és mtársai., 1972). Popper ezt a következtetést vonja le mindebböl: „Úgy tünik, az agy az aktivitáson keresztül növekszik, a problémák aktív megoldásán keresztül” (Popper 1977, p. 112).

Ha biológiai sajátosságokra akarjuk visszavezetni a két populáció cortex cerebrijének átlagos mérete közti eltérést, akkor bajban leszünk, ilyen különbségek ugyanis nincsenek. De nem csak egerekre igaz az, hogy ilyen jelentős mértékben ,gyúrná át” az agyat a környezet és a vele való foglalatoskodás. Az ember nem csak fizikai, szociális, de kulturális értelemben is állandóan változtatja, építi környezetét. Ebben a fejezetben egy olyan kognitív összekapcsolódást veszünk szemügyre, mely az elme és körülötte lévő kultúra elemei és gyakorlatai között áll fenn, amelyek átalakítják a velük foglalatoskodó elmét. ${ }^{142}$

Az ezzel kapcsolatos gondolkodás sajátos nehézsége, hogy: „Mivel a kultúránk nagyrészt láthatatlan számunkra, a kognitív ökoszisztémát láthatóvá tenni kihívás” (Michaelian és Sutton 2013, p. 3). Olyan kulturális elemet érdemes tehát keresni, ami épp az idegenség és ismerősség határán billeg: egyrészt kellően idegen ahhoz, hogy „látható” legyen, másrészt annyira mégis ismerős, hogy tudunk beszélni róla. Például az olyan mnemonikus eszközök, mint a memóriapalota, jó kiindulópont lehet a kulturális elemekről való gondolkodáshoz. Születhettünk volna olyan közegbe, hogy természetes legyen az ilyen eszközök használata (amint az ókori rétoroknál az volt), illetve olyanba is, hogy soha ne halljunk róluk. A fontos az, hogy egy ilyen eszköz nem ártatlan vagy semleges a kognitív folyamataink szempontjából, és éppen az lesz számunkra érdekes, ahogy „belenyomja a pecsétjét” az agyi plaszticitásba.

“...a kulturális források transzformatív hatása az individuális kognitív profilokra az, ami a magyarázati értéküket adja. A források elsajátítása és fejlődése reformatálja az agy reprezentációs képességeit” (Menary, 2010a, p. 576).

Sutton javaslata a következö:

„...kezeljük az ilyen architektúrákat, rendszereket és gyakorlatokat egyszersmind kognitívnak és kiterjedtnek, attól függetlenül, hogy a börön kívül találhatók-e. Kognitívak, habár nem közvetlenül és ősi módon természetesek és biológiaiak; és kiterjedtek, habár szó szerint nem externálisak. A kognitív képességeknek, amelyekkel az individuumok több-kevesebb sikerrel kóborolnak ide-oda, olyan történelmük van, amely épp annyira kulturális (...), mint biológiai” (Sutton 2010, p. 209).

\footnotetext{
${ }^{142}$ A kiterjedt elme harmadik hullámának pszichológiai előzményeként Vygotsky (1978)-at érdemes említeni.
} 
Ahhoz, hogy megfelelő mértékben kirajzolódjon e jelenség jelentősége, fel kell mutatni, hogy mely nézettel áll szemben: így fogjuk csak látni, valójában miben áll a nóvuma. Ez röviden az elme univerzalitásának koncepciója, mely az újkorban született, és a mai napig áthatja a mainstream kognitív tudományos (és az intuitív, hétköznapi) gondolkodást is. Az újkori racionalista és empirista gondolkodók szöges ellentéteik dacára hasonló mértékben ágyaztak meg ennek az elképzelésnek. És bár elősorban Descartes-tal szokás szembeállítani az általunk preferáltabb radikálisabb elméleteket, az empirista gondolkodóknál is tetten érhető az univerzalitás, ${ }^{143}$ sőt, valamilyen szinten az innátizmus ideája is: hisz az elme üres lap, melyet a tapasztalat ír tele, azonban azok a módok, ahogyan a tapasztalat írhat a papírra, rögzítettek. Itt tehát felmutatható egy jelentős párhuzam.

Az emberi kognitív folyamatok univerzalitásába vetett hitet csak még tovább mélyítette a számítógép megjelenése, mely ezekre az alapokra szinte magától értetődően kínálta fel a hardver-szoftver analógiát:144 a biológiai módon rögzített agy a hardver, melyen adott szabályok szerint adatfeldolgozási folyamatok futnak mint szoftver, továbbá a környezeti ingerek biztosítják az inputot, melyekből aztán a rendszer olyan outputokat generál, mint amilyenek a hitek vagy a viselkedés.

Ilyen keretben gondolkodván közel sem meglepő, hogy az elme tartalmai és folyamatai élesen elkülönülnek; csakhogy kísérleti eredmények jelentős hányada azt látszik alátámasztani, hogy egy ilyen keret nem képes adekvát módon kezelni a mentális jelenségek egy fontos részét.

Nisbett és mtsai. (2001) tanulmányukban azt próbálják alátámasztani, hogy a különböző kultúrákban található különbségek nem csak a világ különböző aspektusaival kapcsolatos hiteket határozzák meg, hanem az adott kultúrákban élő egyének kognitív folyamatainak természetét is. Így mosódik el a tartalom és folyamat közti éles határvonal, és így nyer alátámasztást, hogy a kognitív folyamatok nem univerzálisak, legalábbis akkora mértékben nem, mint azt korábban gondoltuk. Gondolatmenetük szerint:

„(1) a szociális berendezkedés a világ bizonyos aspektusaira irányítja a fígyelmet egyéb aspektusok kárára; (2) az, hogy mire figyelünk, befolyásolja a metafizikánkat ${ }^{145}$ (hogy mit tartunk a világ természetéről és az okságról); (3) ez a naiv metafizika irányítja a tacit, implicit

\footnotetext{
${ }^{143}$ Az elme univerzalitásának eszménye az empiristák közül megtalálható pl. Lockenál, Humenál és Millnél is.

${ }^{144}$ Hogy ez az analógia pontosan hogyan értendő, azt ehelyütt nincs módunk részletesen bemutatni. Ehhez lásd pl.: Block 1995.

${ }^{145}$ Egy naiv, népi metafizikáról van szó.
} 
episztemológiánkat: az azzal kapcsolatos hiteinket, hogy mit fontos tudni, és ezt a tudást hogyan lehet megszerezni; (4) ez az episztemológia némely kognitív folyamatok alkalmazását és fejlődését irányozza elő más folyamatok kárára; (5) a szociális berendezkedés és gyakorlatok közvetlen módon hat(hat)nak a metafizikai előfeltevések plauzibilitására, pl. az arra vonatkozó előfeltevés helyességére, hogy a kauzalitás inkább az individuális tárgyban, vagy pedig az azt övező mezőben rejtőzik-e; (6) a szociális berendezkedés és gyakorlatok közvetlenül befolyásolják az olyan kognitív folyamatok fejlődését és használatát mint pl. a dialektikus kontra logikus folyamatok" (Nisbett és mtsai. 2001, p. 291).

Nisbett és mtsai. tanulmánya az individualista és kollektivista társadalmak közti különbségek kognícióra gyakorolt hatásait vizsgálja, ${ }^{146}$ ezek pedig az analitikus és holisztikus gondolkodási mód kategóriáiba sorolhatók be. Fontos megjegyezni, hogy nincs tisztán egyik sem: ezek a kategóriák a spektrumon lévő szélsőségeket jelölnek inkább, illetve az ezekkel korrespondáló kultúráknak ezek felé vannak tendenciáik. A szerzők „holisztikus gondolkodásnak" azt nevezik, amikor a fígyelem a kontextusra, a mezőre legalább annyira irányul, mint az individuális tárgyakra, illetve az oksági magyarázatokban és előrejelzésekben az ilyen jellegü összefüggések és kapcsolatok fontos szerepet játszanak.

Ezzel szemben az ,analitikus gondolkodást” úgy definiálják, melyben az individuális tárgyat kontextusától függetlenül szemléljük, tulajdonságai alapján pedig kategóriákba soroljuk: kauzális jóslatainkat pedig e kategóriák szabályai szerint alkotjuk meg. A dekontextualizáció, formális logika és az ellentmondásmentesség elve jellemzik.

Anélkül, hogy elvesznék az ilyen gondolkodásbeli különbségek kultúrtörténeti elemzéseiben, álljon itt csupán néhány ellentétpár, melyek vizsgálata során láthatjuk, hogy az antik görög filozófia tendenciózusan melyikre helyezte a fókuszt a kínaival szemben (illetve azt is, hogy ennek okán a mai napig melyik jellemzőbb nyugaton): kontinuitás versus diszkrétség, mező versus objektum, kapcsolatok és hasonlóságok versus kategóriák és szabályok, tapasztalat alapú tudás versus absztrakt analízis. E különbségek és jelentőségük érthetőbbé válnak, amint konkrét példát veszünk.

Masuda és Nisbett (2001) realisztikus animációt vetített amerikai és japán alanyoknak, melyben halakat és egyéb víz alatti dolgokat lehetett látni. Amikor utóbb kikérdezték őket, az amerikaiak először föleg a központi halról tettek kijelentést, a japánok pedig általában a háttér elemeiröl. És habár mindenki tett kijelentéseket a központi halról, a japán alanyok azonban

\footnotetext{
${ }^{146}$ A tanulmányt egy az ókori görög és kínai társadalmi berendezkedés összehasonlításával, és az ezekből fakadó értékek elemzésével kezdik, amelyből a kimutatott kognitív különbségeket eredeztetik. Az ilyen jellegü kutatás és gondolkodás meglehetősen jó példa a Sutton 2010 által is propagált interdiszciplináris kognitív kutatásokra.
} 
70\%-kal több kijelentést tettek a háttérrel kapcsolatban, továbbá kétszer annyit a környezet élettelen elemei közti kapcsolatokról (például „a nagy hal elúszott a szürke hínár mellett”). Egy ezt követő felismerési feladatban a japán alanyok kompetenciája csökkent, ha a központi halat egy másik háttér előtt mutatták, míg az amerikai alanyoknak nem jelentett gondot így is felismerni azt. A háttér, kontextus és egyéb relációs tulajdonságok jelentősége így jól látható a japán alanyok percepciójában, szemben az amerikaiakéval.

Egy másik kutatás (Ji és mtsai, 2000) szintén a dekontextualizálás képességével kapcsolatos. Ebben amerikai és távol-keleti alanyoknak kellett jelezniük, hogy egy mozgó vonal helyzete mikor tünik függőlegesnek: csakhogy volt körülötte egy négyszögletes keret, mely szintén mozgott. ${ }^{147}$ A percepció közegtől való függőségének (field dependency) mértéke attól függ, hogy a keret helyzete mennyire befolyásolja az alanynak a vonal pozíciójával kapcsolatos ítéleteit. A teszten a távol-keleti alanyok többet hibáztak, továbbá bizonytalanabbak is voltak az ítéleteik pontosságát illetően, mint az amerikaiak, tehát ítéleteik jobban függtek a közegtől.

A szociálpszichológia egy korábban már általunk is érintett, jól dokumentált jelensége a fundamentális attribúciós hiba (fundamental attribution error) (Ross, 1977). Ennek lényege, hogy hajlamosak vagyunk a viselkedést az ágens diszpozícióinak tulajdonítani, és ezzel szemben elsiklani meghatározó szituációs tényezők felett: magyarán kauzális magyarázataink során az individuumot és annak tulajdonságait helyezzük a középpontba, holott gyakran ezek valójában nem, vagy csak sokkal kevésbé játszanak szerepet a viselkedésben, mint hisszük. ${ }^{148}$ Az eddig bemutatott kísérleti eredményekkel összhangban azt látjuk, hogy azok, akik kollektivista társadalmakban nevelkedtek, kevésbé receptívek erre a hibára, és a kontextuális elemeket is számításba veszik magyarázataik során (Miller, 1984), és így sokszor elörejelzéseik is pontosabbak az ilyen helyzeteket illetően.

Ennek az előnynek azonban megvan a hátulütője is, ez pedig az „utólagos elörelátás” (hindsight bias) ${ }^{149}$ jelenségének vizsgálatakor ütközik ki. Ennek lényege, hogy post hoc az események kimenetele, illetve azok megjósolhatósága egyértelmünek tünik, még akkor is, ha korántsem volt az. Mivel a távol-keleten nevelkedett alanyok feltételezik, hogy események hátterében potenciális tényezők szélesebb köre játszott közre az adott kimenetel elérésében, nehezebben veszik észre, ha egy kimenetelt valójában nem lehetett megjósolni. Ezt remekül

\footnotetext{
${ }^{147}$ Ezt a tesztet Witkin és mtsai. (1954) alapján Rod and Frame Tesztnek nevezik.

${ }^{148}$ Erről kicsit bővebben az „Elfogadhatatlan én-kép” alfejezetben beszéltünk.

${ }^{149}$ Fischhoff, 1975.
} 
illusztrálja a következő kísérlet. ${ }^{150}$ Az alanyok egy történetet hallgattak egy kedves és vallásos papnövendékröl, aki épp prédikálni siet, ugyanis késésben van, és útközben találkozik egy fekvő emberrel, aki a segítségét kéri. (A) helyzetben a kísérletvezetők nem mondták meg, mit cselekszik a papnövendék: azt kérdezték az amerikai és koreai alanyoktól, hogy mekkora esélyét látják annak, hogy a papnövendék megáll segíteni. Erre mindenki körülbelül 80\% esélyt adott, és a kérdésre, hogy mennyire lennének meglepődve, ha nem állna meg segíteni, egyöntetüen azt felelték, hogy meglehetösen. (B) helyzetben a kísérletvezetők elmondták elöre, hogy a papnövendék megállt segíteni, (C) helyzetben pedig azt, hogy nem állt meg. Ez utóbbi két esetben azt kérdezték az alanyoktól, hogy mit tippeltek volna ugyanezen kérdésekre, ha nem tudják elöre, miként cselekedett a papnövendék. (B) helyzetben az amerikai és koreai alanyok újfent $80 \%$ esélyt adtak a segítségnyújtásnak, és azt mondták, nem lettek volna meglepődve, hogy a papnövendék valóban megállt segíteni. (C) helyzetben azonban már jelentős különbség mutatkozik. Az amerikai alanyok még mindig 80\%-ra tippelték volna az esélyét a segítségnyújtásnak, és meglepődésüknek adtak volna hangot, hogy nem így történt. Ezzel szemben a koreaiak (C) helyzetben azt gondolták, hogy csupán 50\% esélyt adtak volna annak, hogy a papnövendék megáll segíteni, és csak kevésbé lepődtek volna meg, hogy nem így történt. Így egyrészt az amerikaiak receptívebbnek bizonyultak a meglepődés érzésére, továbbá a koreaiak markánsan beleestek az utólagós előrelátás illúziójába: hiszen azt gondolták, hogy mindvégig tudtak valamit, amit valójában nem tudtak. Így azok a megbúvó előveltevések a világról, amelyek a távol-keleti alanyok elméjét védik a fundamentális attribúciós hibától, sebezhetőbbé teszik az utólagós előrelátással szemben, és csökkentik az episztemikus kíváncsiságukat is (kevésbé lepődnek meg a nem várt kimenetelektől) (Nisbett és mtsai. 2001, p. 299).

A nyugati elme számára a formális logika, a kizárt harmadik és az ellentmondásmentesség elve képezik a központi szervező elvet, ha egymásnak ellentmondó propozíciók közül kell választania (például el kell dönteni, hogy két eset közül melyik a valószínübb). A döntés vagy-vagy jellegü lesz valamely választott paraméter mentén. Ezzel szemben a keleti elme a kompromisszumra, a köztes megoldásra törekszik, és hajlamos arra, hogy egy gyenge érv is gyengítse eredeti pozíciójában, pusztán azért, mert egy másik nézőpont is felmerült, és azt is fígyelembe „kell” vennie. A nyugati ezzel szemben úgy reagál a szembenálló pozíció gyenge érvére, hogy még inkább megerősödik a hite a sajátjában (Nisbett és mtsai. 2001, p. 302).

${ }^{150}$ Choi, 1998 valamint Choi és Nisbett, 2000. 
Ezen eredmények nem pusztán nagyságrendbeli különbségeket mutatnak keleti és nyugati típusú kognitív folyamatok közt, hanem kvalitatív különbségeket is. A kognitív folyamatok szó szerint másmilyenek lehetnek ugyanazon probléma kezelése során attól függően, hogy melyik kultúrában szocializálódott az alany. Mindazonáltal óvatosnak kell lennünk a messzemenő következtetések levonásával.

„Úgy tünik, hogy a feltevés, miszerint a kognitív tartalom tanult és a végtelenségig rugalmas, valamint a feltevés, miszerint a kognitív folyamatok univerzálisak és biológiailag rögzítettek, egyaránt meglehetősen tévesek. Némely fontos tartalom univerzális lehet, és ezek részét képezik a biológiailag adott berendezésnek, míg más fontos folyamatok roppant változékonyak" (Nisbett és mtsai. 2001, p. 306).

Mielőtt tovább mennénk, lássunk még néhány példát arra, hogy mennyire változékonyak és rugalmasak lehetnek bizonyos kognitív és perceptuális folyamatok.

Arra, hogy az emberek által alakított kultúra, és az abban való aktív részvétel milyen jelentős mértékben képes visszahatni annak létrehozójára, jó példa a moken nevü tengeri félnomád nép észlelésével kapcsolatos felfedezés. A moken gyerekek kétszer olyan jól látnak víz alatt, mint az európaiak, mégpedig azért, mert a pupillájuk képes jobban összeszükülni és kitágulni, így alkalmazkodva a víz alatti fénytöréshez - ez a képesség teljesen hiányzik az európai gyerekekből, ezért is tartották úgy, hogy a pupilla kitágulását-beszükülését velünk született reflex irányítja. Csakhogy ugyanerre megtaníthatók az európai gyerekek is, tehát ez a képesség nem lehet öröklött (Gislén, 2003). A kultúra által hordozott szokások gyakorlása a percepció alsóbb szintjein is drasztikus hatásokat képes okozni.

Jó példa továbbá egy korábban, „Az elme modularitása” alfejezetben is említett jelenség, miszerint némely törzsek tagjai ${ }^{151}$ sokkal kevésbé receptívek a Müller-Lyer illúzióra, mint a nyugat-európaiak. Az alapvető percepcionális szinttől kezdve magasabb kognitív funkciókig, úgy tűnik, jelentős hatással van a közeg, amelyben az alany fejlődik.

Mint azt láthattuk már fentebb is, Nisbett és mtsai. 2001 a naiv metafizikát, tacit episztemológiát és kognitív folyamatokat olyan rendszerként látják, ahol ezek kölcsönösen meghatározzák és megerősítik egymást, így egyik nélkül nem értelmezhető a másik sem. Nincsenek tehát a kognitív tartalomtól tisztán elkülöníthető kognitív folyamatok, hiszen az alapvető kognitív folyamatok természete is sokszor változik attól függően, hogy mely

\footnotetext{
${ }^{151}$ Cole és Scribner 1974.
} 
dinamikus rendszerben fejlődött (értsd: melyik kultúrában). Nem nehéz látni azt az összefüggést, mely mindezen eredményeket a dolgozat gondolatmenetébe ágyazhatóvá teszi.

A szerzők maguk is hasonló párhuzamokat vonnak gondolatmenetük és egyéb szerzők között. Lévi Strauss metaforáját használva (Nisbett és mtsai. 2001, p. 307.) és továbbgondolva azzal az analógiával élnek, hogy a kognitív alanyok olyanok, mint az ezermesterek, akik különböző feladataik elvégzésében különböző kognitív eszközöket alkalmaznak: még ha minden kognitív alany ugyanazzal az eszköztárral rendelkezik is eredetileg (innátizmus), óriási különbségek mutatkozhatnak aközött, hogy mely eszközt használják ugyanazon probléma megoldására. Így tehát a távol-keleti ezermesterek bizonyos eszközei táskájuk aljára kerülnek, míg a nyugaton élőké feljebb, és fordítva. De ha a gyakrabban használt kognitív folyamatok hatékonyabbá válását, tehát a neuroplaszticitást is be akarjuk vonni az analógiába, azt is mondhatjuk, hogy a gyakrabban használt eszközök egyre hatékonyabbá is válnak, a ritkábban használtak pedig elsatnyulnak. Dennett (1995) némiképp hasonlóan, ámbár továbbgondolva az eszköz-metaforát, a daruépitő daru metaforáját használja, hogy a kultúrát mint kognitív eszközök hordozóját mutassa fel. A meglévő mémkészlet elemeinek rekombinálásából, továbbépítéséből olyan összetett mentális eszközök jönnek létre, amilyenek addig nem léteztek, mint amilyen a statisztikai vagy költség-haszon elemzések, vagy akár a mnemonikus eszközök is. De hogy is jön mindehhez a kiterjedt elme?

Otto és notesze kognitív rendszert alkotott, mégpedig az alábbi kritériumok miatt.

(1) Az (internális és externális) elemek között kétirányú interakció áll fenn.

(2) Minden elem aktív okságilag.

(3) A rendszer együtt úgy irányítja a viselkedést, ahogy a kogníció általában.

(4c) Ha megváltoztatjuk az externális elemet, megváltozik az alany viselkedése, mintha egy agyrészét változtattuk volna meg.

Miért ne alkalmazhatnánk ezeket a kritériumokat internális, kognitív eszközökre is? Vegyük például az eszközök eszközét, a nyelvet. Akkor is, ha ez a különválasztás erőltetettnek tűnik, hiszen a nyelv nélküli, strukturálatlan gondolkodást problémás elképzelni, de ebből is csak az látszik, milyen mélyen áthatják egymást. Clark szavaival:

„A nyelvi konstrukciók (...) objektumok új halmaza, amely arra invitál, hogy új (nem nyelvi alapú) készségeit fejlesszük ki a használatnak, felismerésnek és manipulációnak. A szentenciális és nem-szentenciális gondolkodás módozatai így ko-evolválódnak, hogy kiegészítsék, de ne replikálják egymás speciális kognitív erényeit” (Clark, 1997, p. 211). 
A nyelvre mint internális eszközre jellemző kognitív komplementaritás és augmentáció, illetve ko-evolúció szépen lefedik (1), (2) és (3) kritériumokat. (4c) érvényessége pedig akkor válik világossá, ha visszatérünk Nisbett és mtsai. (2001) tanulmányához.

Ahogy rámutatnak: „Talán a legáthatóbbak és legfontosabbak minden gyakorlat közül, amelyek fenntartják a kognitív különbségeket, azok, amelyeknek közük van a nyelvhez és az íráshoz" (Nisbett és mtsai. 2001, p. 304). A nyugati és keleti gondolkodási rendszerek közti különbség megtalálható többek közt az írásban is. Nem fontos most számunkra az a „tyúk vagy tojás elsőbbségére" irányuló kérdés, ${ }^{152}$ hogy a kognitív folyamatok jellege alakította-e az írást ilyenné, vagy fordítva: elegendő annyi, hogy a kognitív folyamatok valamint a nyelv (és írás) együttesen fenntartják egymást és meghatározzák a módot, ahogy ezek müködnek. Amíg a kínai és egyéb távol-keleti írások lényegében piktografikusak, addig a nyugati ábécé atomisztikusabb és analitikusabb; előbbi esetében a nyelvtan is elősegíti azt a képet, hogy a világ kontinuus, utóbbi pedig azt, hogy a világ atomisztikus építőelemekből épül fel;153 a keleti nyelvek továbbá kontextusfüggőbbek is, az egyes szavak sokféle jelentése miatt szükség van a szövegkörnyezetre az értelmezéshez (Freeman és Habermann, 1996). Ezzel szemben nyugaton a nyelvi szocializáció során a gyerekeket a szülők sokszor úgy tanítják meg szavakra, hogy kontextustól függetlenül is értsék azokat (Heath, 1982).

Ami (4c) kritériumot illeti, a nyelv mint eszköz, illetve az alany nyelvi közege mint az internális kognícióhoz képest externális elem két módon is megváltozhat. Egyrészt, kétnyelvü (angolul és kínaiul is beszélö) alanyok kognitív müködése, stratégiája megváltozik attól függően, hogy melyik nyelven dolgoznak. Például angolul beszélő kínaiak, ha szavakat kell csoportosítani, a szavak közti kapcsolatokra helyezik a hangsúlyt, amennyiben kínaiul végzik a feladatot; ezzel szemben inkább kategóriák szerint csoportosítanak, ha angolul. (Ji, 2001; Ji és Nisbett, 2001) Ezek szerint (4c) teljesülhet, a hatás pedig akár azonnali is lehet.

De ez a hatás nem feltétlenül azonnali. Vegyük például azt az esetet, amikor az egyik kultúrában szocializálódott személy átköltözik egy másik kultúrába. Kimutatható, ${ }^{154}$ hogy ezen esetekben a személyek kognitív müködése igazódik az új környezethez egy generáció alatt (vagy hamarabb). A fent ismertetett kognitív folyamatok természete is adaptálódik: tehát az alany (kognitív) viselkedése megváltozik, mintha egy agyrészét változtatták volna meg, habár az „operáció” eltarthat egy életen keresztül is.

\footnotetext{
${ }^{152}$ Sőt, ez a kérdés valószínúleg értelmetlen is ebben a helyzetben: épp arról van szó, hogy együtt fejlődnek, koevolválódnak.

${ }^{153}$ Nisbett és mtsai. 2001, p. 304.

${ }^{154}$ Nisbett és mtsai. 2001, p. 307.
} 
Tehát a nyelv, illetve egyéb internalizálható, de eredetileg a külvilágban, a kultúrában hordozott és azáltal tovább adott kognitív szerszámok is alanyait képezhetik kognitív összekapcsolódásnak. Csakhogy ez egy intruzívebb, mélyebb, és sokszor lassabban végbemenő összekapcsolódás, melynek eredetileg externális, de internalizált eleme nem hagyja „érintetlenül” a rendszer originális részét. Olyannyira nem, hogy a különválasztás sokszor igencsak nehéznek bizonyul. Sutton így fogalmaz:

„Miért kellene az internális protéziseket, melyeket a memória-paloták (...) biztosítanak, genuin módon az elmétől externálisnak gondolni? Vajon a kultúra, mütárgyak, morális gyakorlatok választható extrák, csupán nélkülözhető pótszerek, melyek az agy saját változatlan tendenciáin lovagolnak? Vagy pedig inkább (...) elkerülhetetlen, strukturáló kiegészitök, melyek konstruálják és fenntartják a biológiai folyamatokat, melyeket szimultán módon mélyen átalakítanak?" (Sutton, 2010, p. 212. Kiemelés tölem.)

Az agy „változatlan tendenciái”, melyeket a kultúra kvázi különböző díszekkel aggat tele, de lényegében nem változtat meg, olyan tudományos kép, melyet egyre több oldalról ér támadás és egyre nehezebben tartható. A fentiekben azt igyekeztem bemutatni, hogy a kulturális közegből elsajátított mémek és egyéb kognitív szerszámok szépen beleillenek a kiterjedt elme koncepciójába, tehát a kognitív összekapcsolódás ilyen létezőkkel is elgondolható. A transzformatív kognitív összekapcsolódás és kritériumainak explikálásával tulajdonképpen a kiterjedt elme szakirodalmában „harmadik hullámként” fémjelzett vonulathoz csatlakozom, amely közeli kapcsolatban áll egy másik fontos vitával. Ez pedig nem más, mint az öröklés-környezet vita (nature versus nurture), mely épp arról szól, hogy a mentális architektúránk mennyiben fixált biológialag, és mennyiben változtathatják meg azt szocializációs és a környezettel fennálló egyéb interakciók. A vitában egyébként a két szélsőséges álláspont mellett senki sem ágaskodik, nincs a teljes innátizmus vagy teljes környezet pártján senki; a vita a mértékről szól. A vita mélyebb elemzése nélkül is kijelenthető, hogy a túlsúly az evoluciós pszichológia révén az innátizmus felé billenti a vita mérlegét. Prinz szavaival a környezet (nurture) primáciáját hangsúlyozni „radikális pozíciónak tűnik ebben a [tudományos] éghajlatban” (Prinz, 2013, p. 12). Ezt alátámasztandó: az emberi viselkedést kutató tudományok kísérleteiben 96\%-ban WEIRD (Western, Educated, Industrialized, Rich, Democratic) alanyokat vizsgáltak 2003. és 2007. között főleg északamerikaiakat és európaiakat (Arnett 2008), mely eredményeket aztán a kutatók különösebb aggály nélkül általánosítják az emberi természetre. „Ezt a következtetési lépést alig indokolják 
meg vagy veszik védelmükbe" (Henrich és mtsai. 2010, p. 3). Valószínűsíthető, hogy az a feltevés munkál a kutatókban, hogy egyik felnőtt emberi egyed nagyjából olyan, mint a másik, így a kutatás eredményei reprezentatívak az emberiségre nézve; ez pedig az innátizmus előfeltevéseiből következik. Metaforaként a karteziánus atom juthat eszünkbe, melyet bárhol, bármilyen körülmények között vizsgálunk, ugyanolyan.

Remélem, hogy a fentiekben sikerült alátámasztani, hogy ez a kép nem elég árnyalt. Egy hasonlattal élve: az emberi kogníció inkább egy plazmagömbre (vagy Tesla-gömbre) hasonlít, melynek bár vannak rögzített kisülési módjai, mégis nagyban befolyásolja az a tény, hogy miként és hol érünk hozzá.

Prinz (2013) átfogóan bemutatja az emberi természet (és kogníció) paradigmatikusan univerzálisnak gondolt aspektusait, és roppant meggyőzően mutat fel fundamentális különbségeket mindre vonatkozóan a különböző kultúrák között. ${ }^{155}$ Egyébként mindez természetesen nem jelenti azt, hogy pl. az a 96\%-ban WEIRD alanyokat vizsgáló kutatások hiábavalók lettek volna, vagy nem lennének fontos eredmények: csak épp a helyükön kell kezelni őket és óvatosabban levonni univerzális konzekvenciákat belölük.

Prinz provokatív állítása, miszerint ,az emberi elme vizsgálata alapvetően a hely vizsgálata" (Prinz 2013, p. 11) az ebben a fejezetben felmutatott eredmények alapján válik érthetővé. Ha a dolgozat nem is hangsúlyozná a környezet primáciáját a szelekciós folyamat által alakított biológiai apparátussal szemben (ilyesmiben dönteni nem feladata), akkor is jogos következtetésnek tủnik, hogy a biológia kisebb szerepet játszik a kogníció alakulásában, mint azt az innátista szerzők jelentős hányada gondolja, ${ }^{156}$ és ha kellően árnyalt képet akarunk

\footnotetext{
${ }^{155}$ A kultúra és a mentális elválaszthatatlan kapcsolatát egyetlen Prinz-től vett példával szeretném alátámasztani, ez pedig a mentális zavarok esete. A mentális betegségek definiálhatósága és ontológiai státuszának problematikája szétfeszítené ezen értekezés kereteit, azt mindenesetre valószínüleg biztonsággal állíthatjuk, hogy ebben a „tudományos éghajlatban” szokás természetes fajtaként tekinteni rájuk; mint az evolúciós folyamat által létrehozott biológiai gépezetben lévő hibára. Csakhogy ez a nézet szinte bizonyosan téves, tekintve, hogy némely mentális zavarok csak bizonyos kultúrákban jelentkeznek, illetve ugyanazon zavarok külünbözö tünetekkel manifesztálódhatnak a különböző kultúrákban. (És most nem csak arra gondolok, hogy a „mentális betegség" kategóriája szociális konstrukció, ami nagyrészt a társadalom értékítéletein múlik, tehát hogy mi számít „normálisnak” és mi „patologikusnak”.) A kultúrában hordozott hitek és értékek (többek között) meghatározzák, hogy az adott kultúrában élő egyedek milyen módon betegek mentálisan. A nyugaton ismeretlen koro nevủ szorongás például a férfiak attól való mániákus félelme (kelet- és dél-kelet Ázsiában), hogy a péniszük visszahúzódik egészen a hasukba, mely folyamat halállal végződik. A depresszió ezzel szemben nagyon is ismert nyugaton, a távol-keleti országokban azonban másként manifesztálódik, ugyanis sokszor erős fizikai fájdalommal (pl. fejfájással) jár együtt. (Ami nyugaton nem szerepel a depressziót alkotó tüneteggyütes listáján.) Prinz 2013 pp. 285-286.

${ }^{156}$ Kissé paradox módon megfogalmazva: amit (többek között) rögzít a biológia, az épp az emberi természet és kognitív folyamatok rugalmassága. Nem érv, inkább ezzel kapcsolatos gondolataink konzisztenciájára hívja fel a figyelmet a következő kondicionális: ha azt akarjuk mondani, hogy kognitív folyamataink, bármiben is különböznek egy pl. 50.000 évvel ezelőtt élö homo sapienstöl, akkor a kognitív folyamataink nem lehetnek (teljesen) biológiailag rögzítettek. (Vagy az individuumra szükitve: ha bármiben különböznek mentális folyamataink 50 évesen 20 éves korunkhoz képest.)
} 
alkotni róla, akkor az externális elemekkel való emberi interakciót is komolyan kell venni.

A kiterjedt elme „harmadik hulláma”"157 a transzformatív kognitív összekapcsolódással ragadható meg. Sutton a következőképp vizionálja az ezt középpontba helyező kutatásokat:

„Ha lenne a kiterjedt elmének egy elhatárolható harmadik hulláma, az egy deterritorializált kognitív tudomány lenne, amely az eltorzult és újraformatált reprezentációk propagálásával foglalkozik, és amely feloldja az individuumokat a koordináció és több strukturált médium egyesülésének különös locusaiban. Anélkül, hogy ez a harmadik hullám feltételezné az engramok és exogramok elkülönülő külső és belső világait, a természetes és mesterséges közti különbséget (...), úgy elemezné ezeket a határokat mint a fejlődés és kultúra nehezen megszerzett, törékeny teljesítményeit, amelyek mindig nyitottak az újratárgyalásra” (Sutton, 2010, p. 213),

\subsubsection{Az elme kint hordott része}

Mottószerüen a következőképp lehet összegezni ennek az alfejezetnek a fö mondanivalóját: az elménk legnagyobb részét kint hordjuk a kultúránkban. Első pillantásra talán értelmetlennek tünik e mondat, az alábbiakban mégis kísérletet teszek igazolására.

Esett már szó emberi természetről és univerzálékról, és habár a dolgozatban a környezet hatásainak konstitutív szerepe került hangsúlyozásra a kognícióban, ezzel együtt pedig inkább a kognitív folyamatok rugalmassága került a középpontba, azt mégse állítanám, hogy nincsenek univerzálék, melyeket a vak genetikai mutáció és a természetes kiválasztás együttesen alakított ki; legfeljebb annyit, hogy valószínüleg szükebb azon mentális jelenségek köre, melyeket korábban univerzálisnak gondoltunk. Egy ilyen tagadhatatlanul emberi univerzálé például a kultúra is.

A „nemes vadember” felvilágosodás-korabeli toposza, mely szerint az ember magányosan mászkál, és természetét tekintve alapvetően jó (vagy egyébként akármilyen), sőt; hogy egy ilyen lény egyáltalán rendelkezne bármilyen természettel, már problémákba ütközik.

„Az ember idegrendszere nem csupán lehetővé teszi számára a kultúra szabályainak elsajátítását, de meg is követeli azt, ha egyáltalán működőképes akar lenni. A kultúra nem csupán kiegészíti, fejleszti és kiterjeszti az organikus képességeket, hanem logikailag és

157 A kiterjedt elme „harmadik hullámához” kapcsolható szerzők például: Hutchins 1995; Sperber 1996; Suchman 1998; Johnston 2002, p. 481-482; Clark 2003a, p. 130-142, Mackenzie 2004. 
genetikailag is mindezek elött alkotóeleme ezeknek a képességeknek. A kultúra nélküli embert nem egy eredendően tehetséges, de beteljesületlen majomként kell elképzelnünk, hanem egy teljesen esztelen és így müködésképtelen szörnyetegként" (Geertz 1973, p. 68).

„Tehát a sapiens hominid evolúciós örökségének fontos része egy olyan idegrendszer, amely a kultúra behatása alatt fejlődött (általánosan), és amely minden egyedben egy kultúra behatása alatt fejlődik (konkrétan). Úgy tünik, az emberi idegrendszer függ externális modellektől vagy programoktól, ha normálisan akar működni (...)” (Shore 1996, p. 4).

Ismerünk néhány olyan esetet, amikor emberi egyedek a megfelelő környezet nélkül fejlődtek. Ezek a korábban már említett vad gyerekek (feral children) (Newton 2002) esetei, amiből két következtetést is levonhatunk: egyrészt a tipikus emberi fejlődéshez szükség van a szociokulturális környezetre, az emberi „természet” nem képes „önmagából” kibomlani; másrészt az ilyen esetek ritkasága épp azt támasztja alá, hogy ultraszociálisak vagyunk, és alapvető részünket képezi a társas közeg és a kultúra. ${ }^{158}$

A kultúra tehát szerves részét képezi mentális életünknek. Erről könnyen elfeledkezünk a hétköznapi életünkben is: láthatatlan közeg, mint a levegő; sőt, talán még inkább, hisz a levegő hiányával legalább néha szembesülünk, például a víz alatt; a kultúra hiányával azonban soha, kivéve a vad gyerekek eseteit. Ugyanez fejeződik ki abban az általános emberi tendenciánkban, melyet a pszichológusok és filozófusok egyaránt naiv realizmusnak neveznek, és amelynek lényege, hogy hajlamosak vagyunk megfeledkezni a minden észlelés során jelentkező interpretáció lépéséről. Magyarán elfelejtjük, hogy nem közvetlenül a valósággal állunk szemben, hanem annak valamilyen módon megkonstruált interpetációjával.

„A kultúra új tagjai meg vannak győződve arról, hogy a kultúrát ők maguk határozzák meg, hogy úgy viselkednek, mintha ők maguk találták volna ki mindazt, amit a hagyomány teremtett. Egyedfejlődés során strukturális változás megy végbe: az organizmusnak «második természete» lesz a kulturálisan áthatott viselkedés” (Cole 2005 p. 173).

Amit tehát interpretációs stratégiaként a kultúrából sajátítunk el (például a halottakat meg kell-e enni vagy el kell égetni; az ilyen vagy olyan alkatú emberek-e a vonzók), az nem interpretáció eredményeként tünik fel számunkra, hanem úgy, mint maga a valóság; amit

\footnotetext{
${ }^{158}$ Ehhez lásd még: „A társas kiterjedt elme” fejezet.
} 
teszünk, gondolunk, ahogy ítélünk, az mind természetes. Hogy az ilyen ítéletek és értelmezések valójában nem a valóságban gyökereznek, hanem az általunk rájuk projektált értelmezési szintben, akkor válik világossá, amikor találkozunk egy másik kultúra számunkra furcsa, számukra azonban teljesen természetesnek tűnő szokásával. De elegendő is ennyi a kultúra áttetszőségéről.

Mi is az a kultúra? Pontos definíció híján a következőképp foglalhatjuk össze számunkra legfontosabb aspekusait.

A kultúra olyan közeg, mely az információ (például viselkedési, kognitív, emocionális és egyéb mintázatok) extraszomatikus továbbadását lehetővé teszi horizontálisan és vertikálisan, tehát egy generáción belül és generációk között is. Az egyedek e mintákat tanulás útján sajátítják el; továbbá lényegében minden ember elsajátít valamilyen kultúrát, illetve az, amennyit egy egyed hozzáad, alakít, változtat a kultúráján, egészen elenyésző (Brown 2004, pp. 47-48). Most pedig ejtsünk néhány szót ezekről a mozzanatokról.

Az információ továbbörökítésének ezt a módját szokás összehasonlítani a genetikai örökléssel. A kulturális evolúció egysége a mém. ${ }^{159}$ Nem próbálom pontosan meghatározni, hogy ez pontosan mit jelent: ezt a kérdést illetően ugyanis a memetikusok közt sincs konszenzus, sőt, sokan épp e bizonytalanság miatt eleve tagadják egy ilyen tudomány lehetőségét. Nekem nem szándékom ebben az ügyben dönteni, viszont a mém fogalmát bármit jelentsen is pontosan - kiváló heurisztikus eszköznek tartom.

„Mém” alatt valami olyan információs csomagot vagy mintát kell érteni, amit utánozni lehet. Egyszerübb dolgoktól kezdve (mint amilyen egy kőszerszám kipattintásának metódusa vagy egy dallam) összetettebb dolgokig (amilyen pl. a földmüvelés vagy a matematika) minden mém; bár az utóbbiakat célszerűbb - komplexitásuk miatt - inkább mémplexeknek hívni. Dennett úgy határozza meg őket, mint „azok a legkisebb elemek, amelyek

\footnotetext{
${ }^{159}$ A fogalmat Dawkins (2005) vezette be. Olyan nevet akart, amelyik utal az utánzásra (mimesis, miméma), ugyanakkor rímel a „gén”-re. Dawkins megfogalmazását érdemes szó szerint idézni: „Amikor az ürhajósok távoli bolygókra utaznak, és az élet nyomai után kutatnak, számíthatnak rá, hogy olyan élőlényeket találnak, akik számunkra elképzelhetetlenül idegenek, és a földi élölényektől eltérőek. De van-e valami, aminek igaznak kell lennie mindenfajta élet esetében, találják bárhol is, és bármi legyen is a kémiai alapja? (...) Nyilvánvaló, hogy ezt nem tudom, de ha fogadnom kellene, a pénzemet egyetlen alapvetö elvre tenném. Ez pedig az a törvény, hogy minden élet replikálódó egységek eltérő túlélése révén fejlődik ki. A mi bolygónkon uralkodó replikálódó egység történetesen a gén, a DNS-molekula. Elképzelhetők mások is. Ha vannak, akkor - feltéve, hogy bizonyos más feltételek is teljesülnek - szinte elkerülhetetlenül egy evolúciós folyamat alapjává válnak. De vajon messzi világokba kell-e utaznunk ahhoz, hogy másfajta replikátorokra, és ennek folyományaként másfajta evolúcióra leljünk? Én azt hiszem, hogy nemrégiben egy újfajta replikátor bukkant fel éppen ezen a bolygón. Itt van, és belebámul a képünkbe. Még gyermekcipőben jár, még esetlenül sodródik ide-oda őslevesében, de máris oly gyors evolúciós változáson megy át, hogy mögötte a jó öreg gén messze lemaradva liheg. Az új leves az emberi kultúra levese" (Dawkins, 2005, p. 178. Ford: Síklaki István).
} 
megbízhatóan és termékenyen másolódnak” (Dennett, 1995, p. 344). ${ }^{160}$ Néhány példa mémekre, Dennettől (1991): kerék, ábécé, kalkulus, sakk, az Odüsszeia.

A gének és mémek közötti egyik legjelentősebb különbség, hogy a gének ugyanúgy adódnak tovább (a mutációkat leszámítva), bárhogy él, bármit tanul, bármilyen változásokon megy is át az azokat hordozó egyed élete során; amilyen génekkel születünk, azokat adjuk tovább: a gének tehát rögzítettek, szilárdak. A biológiai evolúció nem képes mit kezdeni a szerzett tulajdonságokkal; a fenotípus egész egyszerüen nem képes visszahatni a genotípusra, legfeljebb a génállomány továbbításának sikerében lehet szerepe. Például hiába dolgozza ki valaki tökéletesre az izmait, az utódaira ez a tulajdonság nem száll át, ugyanakkor génjeinek továbbadására nagyobb az esélye, ha egy olyan közegben él, ahol ez vonzó tulajdonságnak számít. Ezzel szemben a kulturális evolúció, a mémek örökítése lamarcki módon ${ }^{161}$ zajlik: az egyedek képesek továbbadni, és általában tovább is adják életük során szerzett olyan tulajdonságaikat, mint a viselkedési minták, hitek, stb. Ráadásul nem csak az utódaiknak, hanem bárkinek. Így tehát egy sikeres mém összemérhetetlenül gyorsabban terjed el, mint egy sikeres gén, melynek elterjedéséhez generációk hosszú sorára van szükség. A genetikai mutációk sokkal ritkábbak is, mint a memetikaiak. Elég, ha arra gondolunk, amikor egy valakitől hallott szórakoztató anekdotát mesélünk tovább. Egy ilyen esetben is megannyi különbség jelentkezik, így a mémek sokkal nagyobb variablitiást mutatnak. ${ }^{162}$

A mémek óriási építménye alakul ki minden kultúrában, és most, az információ korában, ez az építmény minden korábbinál hatalmasabb és gyorsabban is változik. Az alábbi elnagyolt vázlattal kísérletet teszek rá, hogy érzékeltessem ezen ágas-bogas építmény épülésének valamilyen lehetséges logikáját. Vegyük a kerék mémjét. Ez a mém rekombinálható egyéb mémekkel, így például, ha a kerék felületét nem simának, hanem megfelelő módon recésnek képzeljük el, akkor a fogaskerékhez jutunk, így egy másik „kerék”

\footnotetext{
${ }^{160}$ Nincs teljes egyetértés, hogy tulajdonképpen mi is a mém egysége, és habár ez sokakat arra vezet, hogy a memetikát egy az egyben elvesse (pl. Hull, 1982), Blackmore amellett érvel, hogy ez valójában nem probléma (Blackmore 2001, p. 92).

${ }^{161}$ Ennek a kijelentésnek csak akkor van értelme, ha nem vonunk túl szoros párhuzamot gének és mémek között. Az analógia ott tulajdonképpen véget is ér, hogy a gén és a mém egyaránt replikátor (Blackmore 2001 p. 103).

${ }^{162}$ A mémek koncepciójának egyébként egy másik probléma megoldásában is lehet óriási szerepe, és ez, habár inkább érintőlegesen, mégis kapcsolódik gondolatmenetünkhöz. A probléma a hominid agyméret robbanásszerü megnövekedése. Az agy óriási költségekkel jár - mind az energia, mind pedig az evolúció szempontjából, és nem világos, milyen szelekciós nyomások vezethettek - lépésről lépésre, apránként! - olyan komplex szerveződésekhez, amilyeneket az agyban találunk. Blackmore (1999/2001) az utánzás képességét és a mémek megjelenését tartja a fordulópontnak, ami katalizálta ezt a fejlődést, mégpedig azért, mert megváltoztatták a szelekciós környezetet. A jobban utánozni képes, tehát a mémeket jobban kezelő egyedek sikeresebben adták tovább génjeiket, mert le tudták másolni a hasznos trükköket fajtársaikról, és ez evolúciós előnyt jelentett. Így az az evolúciós pszichológiában bevett nézet, miszerint a ,gének tartják pórázon a kultúrát” borulni látszik, mivel inkább „egymást tartják pórázon”. Ez a dolgozat gondolatmenetébe ott szervesül, amikor az innátizmus és a biológiai megközelítés túlkapásai ellen érvel.
} 
is meg tudja hajtani, ami a fogaskerék által meghajtott további lehetséges mémekhez nyit utat. Vagy, ha vesszük a kerék - valamilyen értelemben vett - inverzét, és nem azt akarjuk, hogy ő menjen valamilyen felületen, hanem a felület haladjon alatta, ezzel meghajtva a kereket, akkor a vízmalomnál járunk; innen pedig már egészen kis gondolati lépés például a szélmalom, ami viszont már alig hasonlít egy kerékre. És ezek mind alapjait nyújtják további lehetséges mémeknek. De vehetünk sokkal komplexebb mémeket is. Az eukleidészi geometria akár egyetlen axiomájának megváltoztatásával egy másik rendszer rajzolódik ki, mely további fizikai elméletek fundamentumául is szolgálhat. Amit itt hangsúlyozni szeretnék, az nem más, mint hogy mémek ilyen leszármazási vonalainak hálójában élünk, és akár néhány egyszerübb mémből rekombinálással és egymásra épüléssel valóságos szellemi felhőkarcolók, de inkább városok épülnek. Ezeket népesítjük be, mentális értelemben ezekben élünk.

Ebből a képből a memetikai evolúció egy olyan aspektusa rajzolódik ki, mellyel a biológia vak evolúciója nem rendelkezik: egyfajta tudatosság, teleológia. Hiszen, ha veszek egy mémet, elkezdhetem szándékosan átalakítani valamilyen célból. Erre a gének esetében nem volt mód, várni kellett a véletlenül megjelenő mutációra (egészen a génsebészet megjelenéséig ${ }^{163}$ ). További különbséget jelent, hogy egy újonnan kitalált mém sokszor tesztelhető akár gondolatban is, és ha „életképtelen”, akkor el lehet vetni. A gének esetében az egyed élete maga a tesztje annak, hogy mennyire rátermettek.

Erre a mémekkel kapcsolatos tudatosságra és teleologikusságra szeretnék az alábbiakban kitérni, illetve arra, hogy ezek kognitív értelemben mennyire ,ártatlanok”. Még általánosabban pedig: mi hozzuk létre őket, vagy inkább ők minket? Ki, vagy mi a valódi ágense a mémeknek?

Mindez a következők miatt tartozik hozzá a lehető legszorosabban az eddigi gondolatmenethez. Amint azt a korábbi fejezetekben láttuk, a kulturális közeg, melyben élünk, meghatározza, amiről gondolkodunk, és azt is, ahogyan ezekről gondolkodunk (továbbá ahogy érzünk, vágyakozunk, boldogok vagyunk, vagy mentális betegségekkel küzdünk). A transzformatív kognitív összekapcsolódás révén a memetikai struktúra, melyet az enkultúrálódás, szocializációnk és tanulásunk során elsajátítunk - a kiterjedt elme fogalmi keretei közt legalábbis - szó szerint része az elménknek. Így az, hogy a mémek hogyan müködnek, magának az elmének az ügye; bármely leírás, mely ezt nem veszi számításba, így szükségképp hiányos lesz.

\footnotetext{
${ }^{163}$ Ennél direktebb példa nem is létezik arra, amikor a kultúra „tartja pórázon” a biológiát.
} 
Popper (2009) ${ }^{164}$ három világ elmélete nem a legnagyobb visszhangot keltő elmélet, még saját munkásságán belül sem, de meglátásom szerint a harmadik világ koncepciójával valami nagyon fontosra tapintott rá, aminek továbbgondolásával az elménk alapvető müködéséhez kerülhetünk közelebb. Lássuk, hogy mi is ez.

Popper a világ létezőit három különböző ontológiai kategóriába sorolta (2009, p. 58):

1. világ: fizikai tárgyak (organizmusok is)

2. világ: mentális tapasztalatok (tudatosság, szubjektivitás), tudás, diszpozíciók

3. világ: az emberi elme termékei (elméletek, problémák, ideák).

Fontos megállapítani, hogy Popper reálisnak tartotta a 3. világot, ugyanis interakcióba léphetünk vele: hathatunk rá és hat ránk. A 2. világ, tehát az elménk révén pedig közvetítődhet az 1. világba is, ahol mint konkrét publikációk, koncertek vagy WC csészék fizikai létet is nyernek az abban található eszmék. (De nem feltétlenül. Popper szerint például a Hamlet léte - onnantól, hogy létrejött - nem attól függ, hogy épp előadják-e, vagy hogy szövege létezik-e kinyomtatva a világban.) Ezek a fizikai tárgyak pedig hordozzák a 3. világbeli ideákat magukban. „[...] egy új alkotásban a szobrász arra bátoríthat más szobrászokat, hogy másolják le" (Popper és Eccles, 1977, p. 39).

Ami ebben a pluralista ontológiában számunkra érdekes, az a harmadik világ természete. A harmadik világot betöltő létezők mutatnak hasonlóságokat a platóni ideákkal, ám mégsem összekeverendők velük, ugyanis Poppernél ezek csakis az emberi elme következtében jönnek létre, nem öröktől fogva léteznek. Sőt, a harmadik világ létezői a fizikai világból nőnek ki, ugyanazon darwini törvényeknek ${ }^{165}$ alárendelve.

„... a harmadik világ gondolatát (...) eszembe se jutott semmilyen formában kiadni, (...) amíg rájöttem, hogy evolúciós magyarázatot lehet hozzá adni azzal, hogy összekötjük az állati termékekkel, és rámutatunk, hogy az építészet végülis ugyanaz, mint amikor a méhek és

\footnotetext{
164 Popper munkássága nem csak itt kapcsolódik gondolatmenetünkhöz, tulajdonképpen a kiterjedt elme koncepció méltatlanul elhanyagolt előfutárának is tekinthető. Einsteinnek tulajdonít egy mondást, miszerint „A tollam okosabb, mint én”, és ezt a kiterjedt elme teoretikusaihoz hasonló módon értelmezi. „Azáltal, hogy leírta a papírra, és papíron számolta ki a dolgokat, gyakran olyan eredményekre jutott, amelyek túl voltak az elvárásain. Azt is mondhatjuk, hogy a toll és a papír használatával bekapcsolta magát az objektív tudás harmadik világába." (Popper, 2009, p. 42) A kiterjedt elmében is hangsúlyos kétirányú interakció még inkább kiviláglik a következő idézetből: „De ez nem csak belölem ered [értsd: a munka végső formája]. Abból a kölcsönhatásból ered, ami köztem és aközött van, amit csinálok. (...) Az egyik leglényegesebb mondanivalóm, hogy nem csak mi hatunk a 3. világra, hanem a 3. világ is hat ránk.” (Uo., 55.)

${ }^{165}$ A tudományos elméletek és problémamegoldás popperi sémája a következő: $\mathrm{P}_{1}$-> KE -> HK $>>\mathrm{P}_{2}-$ ahol $\mathrm{P}$ a probléma, amiböl kiindulunk, KE a kísérleti elmélet, HK a hibakiküszöbölés: a kísérlet, kritika, falszifikáció, ami az újabb problémához vezet. Ugyanez a séma érvényes Popper szerint az egyedekre vagy fajokra is, amelyek szintén mindig problémákat oldanak meg, történetesen a túlélés problémáját. Ezért van folytonosság a természeti és kulturális világ között.
} 
madarak fészket csinálnak, csak valamivel bonyolultabb. És kevésbé ösztönös"166 (Popper, 2009, p. 33).

„Az emberi elméletalkotást - azaz az objektív tudást [értsd: a harmadik világ termékei] tekinthetjük egyfajta bőrünkön kívüli mutációnak, vagy ahogy mondani szokták, $>$ exoszomatikus mutációnak $<$. Az elméletek ebből a szempontból (...) a szerszámokhoz hasonlítanak, amennyiben a szerszámok olyanok, mint az exoszomatikus szervek. Jobb szemek helyett látcsövet és szemüveget növesztünk. Jobb fülek helyett mikrofont, hangosbeszélöt és hallókészüléket. És gyorsabb lábak helyett autót.” (Popper, ibid. p. 23)

Ugyanakkor nagyon fontos hangsúlyozni - és ezt Popper meg is teszi - hogy e világnak van egyfajta autonómiája. Mégiscsak több, mint az elme termékeinek összessége. Egyrészt eredetileg szándékolatlan következményeket tartalmaz, amelyeket inkább felfedezünk, mintsem feltalálunk. Gondoljunk például a matematikai sejtésekre, amelyek épp olyan igazságokra vonatkoznak, amelyeket senki nem szándékozott „beletenni” az adott rendszerbe, sőt, azt sem tudjuk, ott vannak-e. Továbbá az explicitté vált problémákra adható lehetséges megoldások egy olyan logikai teret hoznak létre, melyek az emberi elmétől függetlenül léteznek. Épp ezért lehetséges, hogy egy problémára szinte egyidőben egymástól függetlenül is megtalálják ugyanazt a megoldást. Ezt persze a vak véletlen is magyarázhatná, mégis úgy tünik, hogy bizonyos elméletekre készen áll az adott közeg, és már-már kikényszeríti azt, például a meglévő kísérleti eredmények, az elégtelen magyarázatok és hasonlók miatt. Gondoljunk például Newton és Leibniz elsőbbségi vitájára az infinitezimális kalkulusról (Hall, 1980), de Boris Vian Tajtékos napok-ja sem jöhetett volna létre az antikvitásban. A problémák már mindig korábbi problémák viszonyrendszereibe kerülnek bele, nem keletkeznek ex nihilo, előzmények nélkül, vákuumban. Így válnak egyre komplexebbé a 3. világ termékei, a problémákra adható lehetséges válaszok így strukturálják a szellemi építészet tervrajzát, és így épülnek a szellemi felhőkarcolók és városok.

Még egy, Popper által kiemelt fontos mozzanatot érdemes említeni, mely a kultúra vázlatos definiálására vonatkozó korábbi kísérlet során is elhangzott: ,állandó cserekapcsolat áll fenn az emberek és a 3. világ között, melyben mindig többet kaphatunk, mint amennyit valaha is adhatunk" (ibid. 42). Hiszen az elme tartalmainak legnagyobb részét örökül kapja, majd továbbadja, túlságosan nagy változtatások nélkül. Ennek alátámasztásához elég a legnagyobb korszakos zseniknek tartott személyeket fígyelembe venni, és velük kapcsolatban

166 A valamilyen kultúra létrehozása ösztönös, csak a kultúra konkrét termékeinek (pl. sátor, jurta, ház, felhőkarcoló) létrehozása szakad el a biológiai evolúció rögzítettségétől. 
belátni, hogy a kultúra egészéhez képest milyen apróság mindaz, amit létrehoztak, bármily jelentősek vagy lélegzetelállítók is legyenek egyébként eredményeik.

Popper a 3. világ autonómiájával fontos dologra tapintott rá. És habár ő még nem „replikátorokról” és „mémekről” gondolkodott, úgy látom, hogy e fogalmak mentén komoly feszültségek nélkül gondolkodhatunk tovább az ő nyomdokain, hiszen ezek is darwini törvények alá esnek. Popper számára a 3. világ autonómiája leginkább a szándékolatlan következményekben merül ki, és habár tesz néhány óvatos megjegyzést a lehetséges megoldások objektív létéről is, ezeket nem fejti ki részletesen. ${ }^{167}$ Néhány gondolkodó azonban még tovább megy ezt az autonómiát illetően.

Az ilyen gondolkodók a mémeket önálló jogukon tartják replikátornak. Ahhoz, hogy a mémek létrejöhessenek, szükség volt rá, hogy az elmék létrejöjjenek, amelyek a másolódásukat lehetővé teszik, de ugyanez igaz a génekre is, amennyiben bizonyos környezeti feltételek révén alakulhattak csak ki. De onnantól, hogy vannak elmék, a mémek evolúciója is szárnyra kelt, és ez saját törvényszerüségei szerint zajlik. Dawkins így fogalmaz:

„Attól a pillanattól kezdve, hogy az ősleves megteremtette azokat a feltételeket, amelyek közt a molekulák másolatokat készíthetnek önmagukról, maguk a replikátorok vették át a hatalmat. Több mint hárommilliárd éven át a DNS volt az egyetlen említésre méltó replikátor a világban. De nem szükségszerü, hogy örökké megőrizze monopóliumát. Ha olyan feltételek alakulnak ki, melyek között egy újfajta replikátor másolatokat tud készíteni magáról, az új replikátor át fogja venni a hatalmat, és el fogja indítani a saját új típusú evolúcióját. Amint ez az új evolúció kezdetét veszi, semmiképpen sem szükségszerű, hogy a régit szolgálja. A régi, génszelekción alapuló evolúció azáltal, hogy megteremtette az agyakat, biztosította azt a «levest», amelyben az első mémek felbukkantak. Amint az első önmásoló mémek megjelentek, nekilendült saját, sokkal gyorsabb evolúciójuk. Mi, biológusok, oly mélyen elsajátítottuk a genetikai evolúció eszméjét, hogy hajlamosak vagyunk elfelejteni: ez csupán egy az evolúció sok lehetséges fajtája közül”" (2005, p. 180).

Dennett ugyanezt a gondolatot így fogalmazza meg:

„A mémek első szabálya, amint a géneknek is, hogy a másolás nem szükségszerüen szolgálja bárminek a javát; azon replikátorok terjednek, amelyek jók a... replikálódásban! - bármily

\footnotetext{
${ }^{167}$ Milyen értelemben léteznek a lehetőségek? Vajon ugyanúgy létezik egy lehetséges vers, mint egy aktuálisan létező vers? De az is kérdéses, hogy valóban létezhet-e úgy a Hamlet - mint ahogy Popper állítja is -, hogy nem létezik az 1. világban egyáltalán? Se leírva, se egy neurális hálóban, agyban vagy adattárolón? Milyen értelemben létezik? És ha létezik, akkor nem ugyanilyen értelemben létezik az összes betü összes leírható permutációja az összes lehetséges nyelven, az összes lehetséges hosszúságban, mint Borges Bábeli könyvtár c. müvében? Itt tehát felmerülnek nyugtalanító kérdések.
} 
okokból is. (...) A lényeg, hogy nincs szükségszerü kapcsolat egy mém másolóereje - a saját szempontjából «rátermettsége» - és a mi rátermettségünkhöz való hozzájárulása között" (Dennett, 1991, p. 203).

Ugyanezt a gondolatot Blackmore szavai is nyomatékosítják:

„Ha a mémek replikátorok - amint meggyőződésem, hogy azok -, akkor nem fognak cselekedni a faj javára, az egyén javára, a gének javára, vagy voltaképpen bárminek a javára, csak a magukéra. Ezt jelenti a replikáció fogalma" (2001, p. 63).

Poppernél a 3. világ létezői még mentálisan konstruált „szerszámok” voltak, a túlélés eszközei, és sorsuk sokszor egy volt az organizmussal. Amennyiben nem segítették kellőképp az egyedet, vagy akár hátráltatták, eliminálódtak az egyeddel, fajjal együtt, ha azok nem cserélték le őket időben. Popper egy olyan közösséget hoz példaként, amelyik hitt abban, hogy a tigrisek élete szent, csakhogy balszerencséjükre tigrisek közelében éltek. És mivel a tigrisek nem rendelkeztek hasonló hittel a közösséget illetően, az rövid úton eliminálódott azzal az elképzeléssel együtt, hogy a tigrisek élete szent (Popper, 2009, p. 22).

Ha formalizálni akarjuk, hogy Popper szerint egy mém miért terjed el (habár ő nem így hívta), akkor az így néz ki:

X mém azért terjedt el, mert X a túlélés szempontjából hasznos az emberek számára. Ezzel szemben a mémeket mint második replikátorokat komolyan vevő gondolkodóknál ez a formalizáció a következő:

$\mathrm{X}$ mém azért terjedt el, mert $X$ jó replikátor. ${ }^{168}$

Számukra a genetikai és memetikai evolúció olyannyira különválik, hogy akár olyan éles érdekellentétek is kialakulhatnak, melyben a mém és annak hordozója genetikai kódjának másolódási esélyei közti diszkrepancia a maximálisra nő, és egy zéró összegü játék alakul ki; vagy az egyik, vagy a másik másolódhat csak tovább. Erre a legszélsőségesebb, és ezért legjobb példa az öngyilkosság. Ahogy Dawkins fogalmaz:

„...az a mém, amely az öt magában foglaló egyedet öngyilkosságba kergeti, nyilvánvalóan súlyos - bár nem szükségszerüen végzetes - hátrányba kerül. Ahogy egy «öngyilkossági» gén elterjed, nemegyszer kerülő úton (jó példái ennek az államalkotó rovarok dolgozói, avagy a szülői önfeláldozás), úgy terjedhet el egy «öngyilkossági» mém is - például amikor egy drámai

\footnotetext{
${ }^{168}$ Dennett 1991, p. 205.
} 
hatású vértanúság másokat is arra ösztönöz, hogy hitükért a halált válasszák, ami viszont megint másokat késztet öngyilkosságra és így tovább” (Dawkins 1989, p. 12169).

Az emberi elme jellegzetességei természetesen nem elhanyagolhatóak ebben az egyenletben. Nem csak, hogy nélkülük nem jöhettek volna létre a mémek, de a továbbiakban is nélkülözhetetlenek, hiszen épp ezek jelentik azt a szelekciós közeget, melyben a mémek versengenek egymással és másolódnak. A mémek rátermettsége, saját szerkezetükön túl, a mi mentális jellegzetességeink függvénye. Így például az erőszak és szex körül forgó mémek minden bizonnyal biológiai evolúciós okokból - előnnyel indulnak a versenyben az olyan mémekkel szemben, amelyek például Kanttal kapcsolatosak. Az a hír nem fog akkora visszhangot verni a médiában - tehát a mém kevésbé sikeresen terjed -, hogy találtak egy eddig ismeretlen Kant-kéziratot, mint az, hogy egy Kantot övező vita lövöldözésig fajult. ${ }^{170}$ De például egy olyan fiktív intelligens fajnál, amelyik kevésbé lelkes például a szexet illetően (azt mégse mondhatjuk, hogy undorodik tőle, máskülönben valószínüleg kihalt volna, de mondjuk éppen csak tolerálja, kötelező rossznak érzi), a szelektív környezet egészen más lenne a mémek számára, ezért más mémek biszonyulnának sikeresebbnek. Például a fiktív bulvármédia tele lenne frissen talált Kant-kéziratokkal, miközben csak néhány elvetemült egyed kutatna a szex után könyvtárakban. A fontos az, hogy a mémek nem inherensen rátermettek (ahogy a gének sem), hanem a környezetük függvényében, amelyet a mémek esetében az elmék jellegzetességei alkotnak.

Mindez nem jelenti azt, hogy a mémek csupa káros, vagy legjobb esetben is haszontalan paraziták lennének, melyek az emberi elmén élősködnek. Dennett szóhasználatával élve viszonylag jó a „memetikai immunrendszerünk”: „Nem lennénk képesek a túlélésre, ha nem lenne egy a véletlenszerünél hatékonyabb módszerünk arra, hogy kiválasszuk azon mémeket, amelyek segítenek minket" (Dennett 1991, p. 205). Éppen ezért az esetek túlnyomó többségében a mémjeink legalábbis nem károsak. De, amint láttuk, ilyenek is előfordulhatnak: a mémelméletet és a mémek mint replikátorok szemszögéből való vizsgálódást épp azok az esetek legitimálják, ahol az egyedre, közösségre káros mémek terjednek el.

\footnotetext{
${ }^{169} \mathrm{Az}$ individuumra káros mém lehet a mártírhalálnál sokkal kevésbé magasztos is. Például amilyen a Tide Pod Challenge volt 2018. elején, aminek a lényege az volt, hogy a kis színes mosószer csomagot megeszi az ember, mindezt felveszi, és megosztja valamilyen szociális média felületen (a „vicc” az volt, hogy a csomag úgy néz ki, mint valami édesség). (https://www.washingtonpost.com/news/wonk/wp/2018/01/16/there-were-over-10000poison-control-calls-for-people-eating-laundry-pods-last-year/?noredirect=on \&utm term=.0498facc $3 \mathrm{de} 4$ megjelent: 2018. január 16. letöltve: 2018. december 11.)

${ }^{170} \mathrm{https} / / / 444 . \mathrm{hu} / 2013 / 09 / 16 /$ lovoldozesbe-fajult-egy-vita-immanuel-kant-filozofiarol-egy-oroszorszagi-uzletben (megjelent: 2013. szeptember 16. letöltve. 2018. december 9.)
} 
Ezt a felfogást nehéz megemészteni. Egyrészt az elménk devalválódik (újfent). Valóban nem túl vonzó kép, és az emberi lénytől - aki épp hogy elkezdte felfogni, hogy sem a világegyetem középpontjában nem él, sem nem különbözik minőségileg főemlős rokonaitól, sem nem ismeri kimerítően a vele legintimebb kapcsolatban lévő valamit - az elméjébe, önmagába mint gondolatai szerzőjébe vetett hitét is kikezdeni látszik. Dennett ezt mottószerűen így fogalmazza meg: „egy tudós csak egy könyvtár eszköze arra, hogy egy másik könyvtárat hozzon létre" (ibid. 202). Másrészt a mémek létmódjában is van valami különös, ami nehézzé teszi, hogy belehelyezkedjünk az ő szemszögükbe. Hiszen olyan, mintha az elménkkel szemben inkább információcsomagok rendelkeznének ágenciával.

Természetesen még azok közül sem mindenki ért egyet a memetika nézőpontjával (melynek, emlékezzünk, legfontosabb momentuma, hogy a mémek önálló jogukon replikátorok), akik egyébként a kulturális evolúció hívei. Ök épp ezért a „mém” helyett általában a kulturális ,variáns” fogalmát használják (vagy a biológiai evolúcióval való analógiát a lehető leglazábbra vevő egyéb fogalmat). Boutel és Lewens (2016) arra hívják fel a fígyelmet, hogy a memetikusoknak sokszor a szóhasználata is a mémek egy olyan képét erősíti, mintha a mémek maguktól „ugrálnának” egyik fejből a másikba, úgy terjedve, mint egy vírus egy védtelen populációban. Csakhogy - állítják a szerzők - a mémek nem így terjednek: az egyedek adaptálják, és (legalábbis elviekben) értékelhetik, kritizálhatják és elvethetik vagy magukévá tehetik öket. Arra szeretném ezzel kapcsolatban felhívni a figyelmet, hogy ugyanakkor némi passzivitást mégis csak tulajdonítani vagyunk kénytelenek az elméknek, ami miatt bizonyos esetekben tünhet úgy, mintha a mémek „ugrálnának” egyik fejből a másikba: mégpedig például az ideomotoros akció miatt. Externális stimulusok sokszor automatikusan előidéznek viselkedést, anélkül, hogy bármiféle tudatos percepcionális vagy ítélkezési folyamat, értékelés vagy kritika alá lennének vetve (Bargh és mtsai 1996). Ez pedig mégis csak erősítheti a memetikusok szóhasználatának jogosságát.

Mindenesetre e vízió szerint az elmével rendelkező egyedek sokkal aktívabb résztvevői a kulturális gének (vagy variánsok) másolódásának folyamatában. Ebben lehet némi igazság, ugyanakkor érdemes emlékezni Dennett memetikus immunrendszerére, mely szintén azt jelzi, hogy az elme nem csupán passzív befogadója a mémeknek (ám az ideomotoros akciót kiváltó stimulusok ellen ez sem véd).

Meglehet, a memetikusok vírus- és „önző gén”-analógiákat kedvelő fogalmazásmódja az, ami a legtöbb zavart és félreértést szüli, és így több kárt okoz, mint amennyi hasznot hajt. Boutel és Lewens a memetika egyik legnagyobb problémájának azt tartja, hogy a mémek egyszerűen nem olyanok, mint a gének: a kulturális átadás során sokkalta pontatlanabbak. 
(Mondhatni könnyebben mutálódnak, ha a fogalmazásmóddal mi is a memetika malmára akarjuk hajtani a vizet.) És mivel - szól az érv - e különbség miatt a kulturális variánsok nem tekinthetők replikátornak, ezért a memetika alapjai tévesek. Csakhogy ez az ellenvetés a génmém analógiát túl szorosan értelmezi, amit - jegyezzük meg még egyszer - a memetikus fogalmazásmód sokszor tényleg indokolni látszik. Annak szemléltetése érdekében, hogy miért veszi ez az ellenvetés túl szorosan az analógiát, nézzük meg, hogy Dennett hogyan határozza meg a természetes kiválasztás általi evolúciós folyamat kritériumait:

(1) varáció: egymástól különböző elemek bősége

(2) öröklődés vagy replikáció: az elemek képesek lemásolni magukat vagy lemásolódni

(3) különbség a ,rátermettségben”: az elem másolatainak száma különbözik adott időben, mégpedig az elem tulajdonságai és a környezete interakciójának függ vényében (Dennett 1991, p. 200).

Ha ezek a kritériumok teljesülnek, akkor - Dennett szerint - szükségképp elindul egy evolúciós folyamat. Figyeljük meg, hogy egy szó sem esik arról, hogy a másolódásnak mennyire kell pontosnak lennie. A mémeknek egyszerüen ezeknek a kritériumoknak kell megfelelniük, hogy az evolúciójukról beszélhessünk. Márpedig ezeknek megfelelnek.

Sajnos arra nincs lehetőségünk, hogy a memetika és más kulturális evolúciós álláspontok közti vitában jobban elmélyedjünk, így ezeket illetően érdemi állást foglaljunk, ez ugyanis legalább egy külön disszertációt igényelne. De egy ad hominem érvet még megengednék magamnak a mémelmélettel kapcsolatban. Dennett, aki az egyik legszigorúbb és legvéresebb szájú fizikalista, aki - saját megfogalmazása szerint - mindig „földi darukat” keres „égi fogantyúk” helyett, és a tudat „nehéz problémáját” sem megoldhatatlan rejtélynek tartja, továbbá minden folyamatot a darwini törvények alá rendel, nos, ő az, aki a mémeket mint önálló jogukon való replikátorokat a lehető legkomolyabban veszi. Ezzel nem azt akarom mondani, hogy ezért ezt a koncepciót és látásmódot nekünk is kritika nélkül magunkévá kellene tenni. Szó sincs róla. Azt viszont igen, hogy érdemes nagyon komolyan elgondolkodni erről és esetleges következményeiről. Cloak is felteszi a baljós kérdést:

„Ha «saját» jellemző kulturális vonásaink némelyikének rabszolgái vagyunk, nem lenne itt az ideje, hogy megismerjük ezeket?” (Cloak, 1975, p. 178.) 
A dolgozat fö gondolatmenetének szempontjából nincs rá szükség, hogy a mémek és kulturális variánsok valamelyike mellett foglaljunk állást. A kultúra elemei, legyenek azok akár mémek, akár variánsok, alkothatják, és mindig is alkotják a kiterjedt elme externális részét. Különbségek csupán e kulturális elemek autonómiájának mértékében jelentkezhetnek. Meglátásom szerint azonban még a kulturális variánsok pártján álló gondolkodóknak is nagyobb autonómiát, ezzel pedig ágenciát kell tulajdonítania ennek a 3. világnak, ezzel közeledve a memetikusok álláspontjához.

Az alfejezet mottójának alátámasztásához (miszerint az elménk legnagyobb részét kint hordjuk a kultúránkban) érdemes összefoglalni, milyen konklúziókat vonhatunk le a transzformatív kognitív összekapcsolódásról szóló, valamint az ebben az alfejezetben ismertetett gondolatokból. Egyrészt minden tipikus emberi egyed rendelkezik kultúrával; az idegrendszerünk úgy fejlődött, hogy igényli ezt, elszakíthatatlan tőle. A transzformatív kognitív összekapcsolódás segítségével a kiterjedt elme fogalmi kereteiben az elme és a kultúra elemei (a mémek) egyetlen kognitív rendszert képeznek. Másként fogalmazva: természetesebbnek és hatékonyabbnak tünik egy ilyen modell, így „felszeletelni a valóságot”, mint külön kezelni az elmét és a kultúrát. A mémek (viselkedési minták, hitek, artefaktumok, stb.) öröklődése mint testen kívüli evolúció (mely összehasonlíthatatlanul gyorsabb is, mint a genetikai), óriási előnyt jelent az egyedeknek a túlélés szempontjából. Hiszen nincs szükség arra, hogy diszpozícióink genetikusan legyenek rögzítve (pl. a tűzrakásé), sem arra, hogy az egyed mindenre magától jöjjön rá (például próba-szerencse útján); hanem megtanulhatja, leutánozhatja, hogyan kell tüzet rakni, írni, számolni, differenciálegyenleteket megoldani vagy épkézláb filozófiai tézist megfogalmazni, hiszen ezeket korábban már mások kínkeservesen kitalálták, majd a kidolgozott mémek a kultúrában továbbadódtak, a későbbi egyedek pedig sokkal kevesebb munkával elsajátíthatják őket.

Ez a kultúra révén továbbadódó mémkészlet egyre változik és növekszik. Az egyedek magukévá teszik, magukénak érzik, és meglehetősen keveset tesznek hozzá. Akár egy doktori disszertáció is a kultúra nagyon keskeny szeletének egy nagyon kicsi részéhez tesz hozzá valami újat, ha egyáltalán. És ez az óriási memetikai építmény, melynek nem lehet túlhangsúlyozni az előnyeit, korántsem ártatlan. Egyrészt meghatározza, amiket gondolunk (a gondolatainknak nem mi vagyunk a szerzői, vagy csak elenyészően kis mértékben), másrészt azt, ahogyan gondolkodunk, ahogy amellett a „Transzformatív kiterjedés” alfejezet érvelt. A mentális tartalmak és folyamatok közt nincs éles határ. Ennek a ránk nehezedő szellemi építménynek tovább növeli ,zsarnoki” jellegét a láthatatlansága: hogy nem tünik fel, hogy ránk nehezedik, hogy a szokásaink, gondolkodási, érzelmi sémáink mind természetesnek 
tűnnek, holott nem azok, másrészt azon pszichológiai sajátosságaink (ha úgy tetszik, egyfajta pszichológiai malter), melyek a konformitásra bíztatnak minket, és amelyek a körülöttünk élőktől eltérő gondolkodást és viselkedést a fizikai fájdalommal egyenértékü szociális fájdalommal büntetnek. Tehát, ha eszünkbe jutna is másként gondolkodni, a környezetünk (beleértve saját pszichológiai architektúránkat is) ezt megbüntetné. Ehhez a zsarnoki uralomhoz járul hozzá az építmény autonómiája a mémek nem szándékos következményeivel, a lehetséges megoldások és problémák - objektíve létező - logikai terével, továbbá a mémek mint második replikátorok különváló evolúciójával, mely többé egyáltalán nem biztos, hogy a génjeink örökítését, a túlélésünket, boldogulásunkat vagy épp boldogságunkat segítik. Az evidens pejoratív felhangokat leszámítva leginkább egy ganajtúró fajhoz hasonlítunk, melynek több milliárd egyede (mostanra szinte) egyetlen hatalmas, növekvő ganajt görget, melyet már saját lendülete is hajt, melyből az egyedek minden táplálékot és iránymutatást nyernek, és amely nélkül egy percig sem lennének képesek létezni, miközben - szintén a ganajból vett - individualizmusukról szőnek fantáziákat. Ezen aspektusok összességét értettem a fejezet elején szereplő állítás alatt, hogy elménk legnagyobb részét „kint hordjuk” a kultúránkban.

Természetesen ez a kép nem elég árnyalt, hiszen fígyelmen kívül hagyja az óriási individuális különbségeket. Ha körbenézünk, azt látjuk, hogy az emberek kognitív folyamatai egy kultúrán belül is nagyon különböznek egymástól. Valaki úgy érti Heideggert, mintha csak a piacon csevegne, másnak egy bonyolultabb recept értelmezése is nehézséget jelent. Én már akkor bajban vagyok, ha egy százalék-számításnál komolyabb matematikai műveletet kell végrehajtani, mások kvantumfizikai egyenleteket oldanak meg, stb. Vajon lehet-e mindezt azzal magyarázni, hogy az emberi lények a kultúra más területein (szubkultúrákban, kognitív fülkékben) „enkultúrálódnak”, és másmilyen mértékben? („Enkulturálódás” alatt Fabry 2017 nyomán azt értem, amikor egy egyed egy kognitív gyakorlatot elsajátít, mely gyakorlat augmentálja és átalakítja kognitív apparátusát.) Ezeket az eseteket még talán az eltérő enkulturálódás számlájára írhatjuk. De vegyünk egy olyan (meglepően széles körben) elterjedt példát, amikor az ember nem tud tévé (vagy valamilyen ambiens zaj nélkül) elaludni. Az ilyen személy akár találkozhatott is ezzel a mémmel korábban, és az elterjedtség akár még utalhatna is arra, hogy ilyen módon, „felülről lefelé” másolódik. De nehéz lenne belátni, hogy csak azért, mert valaki hall ilyenről, miért tenné magáévá. Ehhez gyakorlat kell. Ésszerübb magyarázat, hogy az ember egyedül szoktatja rá magát, az agy pedig alkalmazkodik a maga plaszticitásával. Ez példa arra, amikor az ember anélkül „tanítja” meg az agyát és alakítja át (valamilyen mértékben) a neurális útvonalait, hogy azt a kultúrából vette volna, vagy valaki 
megtanította volna. Természetesen lehetséges egyedül is tanulni, új kapcsolatokat megtalálni létező mémek között és új mémeket létrehozni. Emberek találnak ki új dolgokat, fejlesztenek ki új készségeket, én csupán ezen esetek elenyészően ritkább voltára szerettem volna utalni.

A prediktív erő figyelembe vételének fontosságát is hangsúlyoznám továbbá a kultúra mint externális elem esetében. Ahogy Dollard fogalmaz:

„Elemzésünknek két fő szereplöje van: a csoport, amely az egyén világrajövetele előtt is létezett, és az új organizmus, amely elképzeléseink szerint e felé a működő csoport felé közeleg. Ebben a pillanatban az organizmust még nem érik kulturális hatások, a csoport pedig az ö hozzájárulása nélkül működik... Nézzük meg, hogy ebben a pillanatban mit mondhatunk el róla, milyen lesz felnőttkorában. Amit vele kapcsolatban előre meg tudunk fogalmazni, feltéve persze a csoportja folytonosságát, hogy meg fogja határozni a kultúrája. Meg tudjuk jósolni például, milyen ruhákat fog hordani, milyen nyelven fog beszélni, milyen eszméi lesznek, mi lesz a foglalkozása, néha azt is, hogy ki lesz a férje vagy a felesége, mivel lehet majd megbántani, milyen lesz az egészségügyi állapota, milyen lesz a személyiségfejlődési elmélete, stb.” (Dollard, 1935, p. 14-15).

Mindehhez hozzátehetjük, hogy az egyelőre meg sem született új organizmus felnőttkori kognitív folyamatainak természetéről és annak tendenciáiról is élhetünk viszonylag megbízható előrejelzésekkel. Ezt pedig, érvelésem szerint, érdemes figyelembe venni az elme elemzése során.

\section{A globális elme felé}

Ebben a fejezetben a kiterjedt elme maximális végiggondolására vállalkozom, hogy ezáltal felmutassam egy globális elme konceptuális lehetőségét. Azt állítom, hogy Clark és Chalmers eredeti koncepciójából szükségszerủen következik ez a tézis is, így ezt akár lehet reductio ad absurdum érvként is érteni, ami alatt azt értem, hogy mivel a globális elme következik az eredeti hipotézisből, és a globális elme tézis elfogadhatatlan, ezért az eredeti hipotézist el kell vetni. Valóban csúszós a lejtő, ha egyszer beengedünk egy egyszerü noteszt a mentális világába. De emlékezzünk a túl szük és túl nagy elmék dilemmájára: ha nem fogadjuk el a kiterjedt elmét (a globális elmével egyetemben), akkor kénytelenek leszünk egy sor olyan dolgot kizárni a mentális világból, amit egyébként szeretnénk részének tudni. 
Ráadásul a globális elme közel sem olyan kontraintuitív, mint amilyennek prima facie tünik. Sőt, ami azt illeti, rávilágít valami nagyon fontosra, ami minket mint kogitáló lényeket azzá tesz, amik vagyunk. A fejezet lépésről lépésre jut csak el a globális elméig, óvatosan bontogatva az ellenkező intuíciókat, valamint bemutatva, hogy miként következik az eredeti hipotézisből.

\subsection{Kognitív intézmények}

Gallagher (2012) valamint Gallagher és Crisafi (2009) a mentális kiterjedésnek egy olyan lehetőségét veti fel, mely egyrészt többé-kevésbé beilleszthető a klasszikus kiterjedt elme keretbe, másrészt feszegeti is azt. Ugyanis explicit módon túllép a paritási elven, sőt implicit módon a kiterjedt elme harmadik hullámába is átmerészkedik. Ebben az alfejezetben ezt a koncepciót vizsgálom, szétválasztva a kognitív összekapcsolódás két összemosódó fajtáját (merev és transzformatív), majd a későbbiekben a számomra elfogadhatónak tűnő konklúziójukat gondolatmenetünk következő állomásához vezető lépcsőfokként használom fel.

A szerzők mentális állapotok (például hitek) helyett inkább olyan kognitív folyamatokra fókuszálnak, amilyen a problémamegoldás. Állításuk szerint az ilyen folyamatokat nem csak fizikai tárgyak (notesz, számológép) segíthetik vagy tehetik lehetővé, hanem szociális gyakorlatok és intézmények is, amilyen például a jogrendszer vagy a tudomány. Ez első ránézésre túlkapásnak tünhet, valójában azonban nem kevésbé védhető álláspont, mint a klasszikus notesz esete. Ismerős motívumként a problémamegoldás három esetét veszik sorra, csak most nem Tetriszről van szó, hanem jogi ítéletalkotásról. Röviden: (1)-ben Alexisnek egymagában, fejben kell ítéletet hoznia egy bizonyos ügyben oly módon, hogy még az ítélethozatal folyamatát is neki magának kell kitalálnia, hogy a lehető legigazságosabb legyen. Hogy mi az igazságos, az is teljes mértékben az ő szubjektiv értékítéletére van bízva. (2)-ben és (3)-ban fokozatosan a folyamat egy-egy lépését mások (akár több ember is) végzik el, illetve a folyamat maga más emberek által rögzített szabályok szerint zajlik (Gallagher és Crisafi 2009, p. 47).

Alexis a három esetben egyre kevesebb kogníciót végez, ugyanakkor a szerzők szerint az esetek összkognitív terhe azonos. (Ha nem egyenesen több a legutóbbi esetben, mely ítélethozatali eljárás a müködő jogrendszereket hivatott jelképezni.) A kognitív teher eloszlik nem csak Alexis és a többi résztvevő (Példásul az esküdtek), de a szabályok között is, 
amelyek korlátozzák, irányítják és lehetővé teszik az ilyen ítéleteket. (És amelyek csak az adott jogrendszer alapján törvényesek.)

„Létrehozzuk ezen intézményeket a saját (megosztott) mentális folyamatainkkal. Aztán instrumentálisan felhasználjuk ezeket az intézményeket, hogy további kognitív munkát végezzünk - pl. hogy problémákat oldjunk meg, és hogy kontrolláljuk a viselkedést" (Gallagher, 2012, p. 6).

Az általam „,B” kritériumoknak nevezett feltételek nem mindig teljesülnek abban az esetben, amikor Alexis összekapcsolódik egy ilyen intézménnyel, tehát az externális elem(ek) nem (1) megbízhatóan elérhetők és általában használtak, nem (2) automatikusan jóváhagyottak (kritika nélkül) és nem (3) könnyen hozzáférhetők. Csakhogy ez nem probléma.

A szerzők ugyanarra az eredményre jutnak, mint Sprevak (2009) révén a dolgozat is jutott korábban, így nincs szükség ezt a lépést rekapitulálni. ${ }^{171}$ Összefoglaló jelleggel:

„Hosszabb és komplexebb folyamatok magukban foglalnak sok elemet, köztük folyamatokat, amelyek szociális intézményeken alapulnak. Komplexitásuk ellenére azonban többé-kevésbé megbízhatók lehetnek, többé-kevésbé elérhetők mint egész, és igényelhetnek némi kritikai metakognitív ellenőrzést. De e tényezőknek nem kellene diszkvalifikálnia ezeket a kognitív folyamatok közül." (Gallagher 2012, p. 7)

A „B” kritériumok tehát nem szükséges feltételei Gallagher és Crisafi szerint sem a kognitív státusznak, így ők is az alapvetőbb „A” kritériumokra támaszkodnak vagy „vonulnak vissza”. A paritási elven is túllépnek, ${ }^{172}$ és ezzel szintén meghaladják az „első hullámot”, de ezt némiképp eltérő módon teszik, mint a dolgozat gondolatmenete. Számukra a „B” kritériumok többé-kevésbé érvényesnek tủnnek az internális folyamatokra, így a komplex externális intézményekre támaszkodó, azokkal összekapcsolódó internális kogníció különböző lesz az internálisaktól. Ez azonban nem probléma, ugyanis az „A” kritériumokat tartják érvényben.

„Nem világos, hogy az elérhetőség, automatikus jóváhagyás és könnyủ hozzáférhetőség miért esszenciálisak a kiterjedt kognícióhoz. A fontos kérdés itt nem az, hogy valami ritka, kritikai

\footnotetext{
${ }^{171}$ Lásd „B” kritériumok, ,Ellenvetések” fejezet.

${ }^{172}$ Innen jön Gallagher 2012 címe is: „A túlterjedt elme” (The overextended mind), ami nem arra utal, hogy a kiterjedt elme koncepciója túlkapás lenne, hanem arra, hogy egy olyan elképzelést explikál, mely túlmutat Clark és Chalmers eredeti tanulmányán.
} 
értékelést igényel vagy könnyen hozzáférhető. A kérdés inkább az, hogy lehetnek-e részei (vagy potenciális részei) egy kognitív folyamatnak" (Gallagher és Crisafi 2009, p. 47).

Az elhanyagolható különbséget az adja, hogy érvelésemben a „B” kritériumok már az internális folyamatokra sem voltak érvényesek. Tehát, ami a kognitív folyamat részévé teszi ezeket az intézményeket Gallagher és Crisafi számára is, az egyrészt a megfelelő összekapcsolódás (kétirányú interakció), továbbá az externális elem nélkülözhetetlen jellege, melynek elvételével csökken a kognitív kompetencia. A kognitív összekapcsolódás több fajtája is összemosódik azonban ebben a két szövegben, illetve az összekapcsolódás leírási szintjeit is külön lehet választani.

Egyrészt Alexis úgy támaszkodik a jogrendszerre és az ahhoz tartozó externális elemekre, szabályokra, szokásokra és emberekre, mint Otto a noteszére (legalábbis nagyjából $\left.{ }^{173}\right)$ : ez tehát felfogható úgy, mint a klasszikus, általam merev kognitív összekapcsolódásnak nevezett kiterjedés.

Másrészt Gallagher (2012)-ben Alexis már jogot is tanult, így az externális jogrendszer internalizálása révén annak transzformatív jellege is van. Ezt „transzformatív” vagy „,visszaható (rugalmas) kognitív összekapcsolódásnak” neveztük. Ennek lényege, hogy az externális elemmel való hosszabb foglalatoskodásnak fundamentális kognitív következményei vannak az agy plaszticitásának folyományaként. Gallagher két példája, melyek alapján valószínűleg jogosan feltételezi, hogy a joggal való foglalatoskodás is transzformatív: Bassolino és mtsai. (2009) és Maguire és mtsai. (2000), melyekben az agy struktúráiban bekövetkező változásokat mutatják ki, egyrészt a hétköznapi számítógépes egérhasználat, másrészt a taxisoförök gyakori navigációs kihívásai eredményeként.

Gallagher magát a tudományt, a tudományos módszert és annak eredményeit ugyanilyen kognitív intézményeknek tartja, mellyel összekapcsolódhatnak a kognitív ágensek. „A tudomány maga, a fogalom modern értelmében egy intézmény, és a tudományos módszer egy eszköz, melyet arra használunk, hogy kiterjessze a kogníciót” (Gallagher és Crisafi, 2009, p. 51).

A merev kognitív összekapcsolódásra példa lehet, amikor egy képletet használunk egy számoláshoz; a transzformatív összekapcsolódásra pedig az, ahogy például a statisztikai elemzések, hipotézisek felállítása, kísérlettervezés az oktatás-tanulás és ezekkel való foglalatoskodás révén második természetünkké válnak. De ha a „kiterjedés” irányát is fontos

\footnotetext{
${ }^{173}$ Egy jogrendszer által tárolt információt pl. nehezebb, lassabb folyamat lehet előhívni, mint kinézni valamit egy noteszböl, de ez nem húsbavágó különbség.
} 
dimenziónak tartjuk, akkor lehet még példákat hozni: a befelé terjedés az internalizációról szól, amikor elsajátítunk mentális technikákat, eszközöket, mintázatokat. Ezek lehetnek transzformatívak (általában valószínüleg azok), de elgondolhatók olyanok is, amelyek mereven, „modulként” csatlakoznak az elméhez, amilyen például a memóriapalota, mely nem szükségszerüen alakít át semmit azon kívül, hogy csatlakozik az elméhez. (Ez akár egy olyan aggyal is lehetséges lehet, amelyik nem plasztikus - ha képes valamilyen okból mégis tanulni.) Ahogy Gallagher és Crisafi is megjegyzik, nehéz elgondolni olyan kogníciót, amelyik nem kiterjedt valamilyen, a mi fogalomhasználatunk alapján transzformatív értelemben (Gallagher és Crisafi, 2009 p. 51).

„Talán helyénvaló azt mondani, hogy a kogníció, ami az individuum fejében zajlik valójában ezen nagyobb folyamatokból - szociálisan intézményesült folyamatokból - származtatottak, vagy talán azok internalizált verziói, amelyek bármely specifikus individuum fején kívül mennek végbe" (Gallagher és Crisafi, 2009, p. 49).

De számunkra elegendő ennyi a transzformatív jellegről, az intézményekről ${ }^{174}$ pedig térjünk át a csoportokra. Azt már láttuk, hogy a Tollefsen (2009) által explikált kollektív elme során két elme összekapcsolódhat, és a két elme több, mint a részek összege (ahogy egy neurális háló is több, mint neuronok összessége) - példaként gondoljunk a tranzaktív memória esetére vagy egy brainstorming ülésre, ahol az eredmény egyik individuális elme révén sem jöhetett volna létre. De miért álljunk meg kettőnél? Hány elme kapcsolódhat össze?

A kiterjedt elmének az a fajtája, amit körvonalazni szeretnék, valahol félúton van az elfogadhatatlannak bizonyuló határtalan elme és a kollektív elme közt. Azt állítom, hogy tetszőleges számú elme alkothat egyetlen kiterjedt elmét - ha megfelelő módon kapcsolódnak egymáshoz.

Ehhez segítségül hívom Block (1978) egy híres gondolatkísérletét. Először is képzeljünk el egy testet, mely kívülről olyan, mint egy tipikus emberi test, belül azonban legalábbis a fejében - homonculusok hemzsegnek, akiknek külön-külön nagyon egyszerü feladatuk van: adott input esetén adott outputot kell generálniuk. (Például ha egy kijelzőn adott kódot látnak, akkor be kell ütniük egy másik, szintén adott kódot - mely a megfelelő

\footnotetext{
${ }^{174}$ Az intézményi struktúrák sokszor (mindig?) lehetővé teszik a gondolkodást, kiterjesztik, támogatják, ugyanakkor irányt is szabnak neki és elvakulttá tehetnek bizonyos lehetőségekkel szemben. Ebben pedig rejtőzhetnek veszélyek is. „Fel kellene tennünk a kérdést, hogy a mechanizmusok és intézmények mit tesznek velünk mint a kogníció szubjektumaival" (Gallagher 2012, p. 11). Gallagher ebben a szövegben valóban csak felteszi a kérdést, és csupán jelzi, hogy annak normativ aspektusai is vannak. Ezt a problémát próbáltuk meg jobban körüljárni a „Kultúra és a mémek autonómiája” c. alfejezetben.
} 
outputot jelenti). Ha elég részletesen ki van jelölve, hogy melyik kis embernek mi a feladata, akkor elvileg funkcionálisan ekvivalens lehet egy ilyen homonculusoktól hemzsegő fejü robot egy emberrel. Hogy a példát nomologikusan lehetségesnek mutassa fel, Block azt javasolja, hogy ugyanezt képzeljük el úgy, hogy a robottest nem homonculusok jól rendezett csapatához kapcsolódik, hanem Kína népességéhez, ${ }^{175}$ mely - tegyük fel - ugyanúgy szerveződik, mint a homonculusok, ugyanazokat a belső mechanizmusokat utánozzák, illetve hajtják végre, ezáltal pedig úgy irányítják a robotot, hogy az viselkedésében megkülönböztethetetlen egy embertől.

A kérdés az, lesznek-e Kínának mint szerveződésnek (tehát nem az egyes embereknek, hanem annak a rendszernek, amelyet alkotnak, mely egy müködő emberi agyat szimulál, egy fö - egy neuron lebontásban) mentális állapotai? Block szerint nem, mégpedig a hiányzó kválé miatt: egy ilyen rendszernek intuitíve nem lesz fenomenális karaktere, kvalitatív állapotai, vagy Nagel (1974) szavaival: nem lesz ,olyan, mint annak (a Kína népessége által irányított robotnak) lenni”. Block ezzel a példával a funkcionalizmus ellen érvel (hiszen, ha Kína népessége nem realizál mentális állapotokat a funkcionális ekvivalencia ellenére, akkor a funkcionalizmus téves), de az érv nyilvánvalóan a csoportelme ellen is érvényes.

Néhány szó erről az érvről és a lehetséges válaszok spektrumáról. Egyrészt állíthatjuk azt, hogy Kína rendelkezik vagy nem rendelkezik mentális állapotokkal. Maga Block is elismeri, hogy az intuícióra való hallgatás könnyen és hírhedten tévútra vezethet. Például Lycan (1987) épp ezért a kontraintuitív volta ellenére állítja, hogy Kína mint elme rendelkezni fog fenomenális karakterrel. Másrészt olyan álláspont is lehetséges, hogy az egyedi emberi elme sem rendelkezik fenomenális karakterrel (pl. Churchland 1981, aki az antirealista álláspont legerősebb verzióját támogatja, vagy Dennett 1988, 1991, aki ennél mérsékeltebben antirealista), és így az, hogy Kína mint elme rendelkezik-e fenomenális karakterrel vagy sem, irreleváns abból a szempontból, hogy tekinthető-e elmének.

Az a fajta elme, amit próbálnék körvonalazni, minden komplexitása ellenére talán könnyebb helyzetben van a hiányzó kválé ellenvetést illetően. Némi párhuzamot vélek felfedezni ezen eset és Block gondolatkísérlete között (ez indokolta a kitérőt), és ezek szétszálazása segít nekünk abban, hogy a Tollefsen által kollektív elmének nevezett nézőpontról gondolkodjunk. A kollektív elme lényege, hogy Otto és notesze mintájára két elmével rendelkező egyed kapcsolódik össze. De ennél Tollefsen is tovább megy: célja az,

\footnotetext{
${ }^{175}$ Block azért választotta Kínát (1978-ban), mert egymilliárd lakosa volt, és úgy hitte, kb. ennyi agysejt van az agyban. Ma már tudjuk, hogy sokkal több agysejtünk van.
} 
hogy a csoportot tegye meg genuin módon mentális tartalmakat hordozó ágenseknek. A két legfőbb ellenvetést a következőben vélem felfedezni. ${ }^{176}$

Egyrészt, ha Olaf és Inga (vagy még több ember) egy hibrid kognitív rendszert alkot, akkor hol ér véget egyikük elméje, és hol kezdődik a másik? És főként: kié az a kognitív rendszer, ami így képződik? Hisz az individuális elme az egyedé magáé (szól az intuitív érvelés): azé, akié a „,végső szó”, akinek az irányítás a kezében van, aki ül a karteziánus színházban, és mérlegel az inputok alapján, hogy mi legyen az output. Csakhogy, amint ezt már a kiterjedt elme klasszikus verziójánál is megnéztük, nem valószínű (legalábbis lehet érvelni ilyen álláspont mellett) hogy lenne ilyen központ. Az én elmém nem igazán az enyém, pusztán elme. A döntéseket nem „hozzuk”, hanem „születnek”. A kiterjedt elme eleve ilyesféle elme-képpel operál, ha nem is mindig explicit módon, de mindenképp tendenciózusan. (Ez ellen persze lehet érvelni, és ha ez nem így van, akkor a kiterjedt elme pozíciója is gyengül és a mérleg nyelve a szűk elme felé billen.) Tollefsen szerint az ilyen ellenvetések abból fakadnak, hogy az elmének egy esszencialista, szubsztantivista képével operálunk: mintha az elme kvázi-szubsztancia ${ }^{177}$ lenne, dolog, ami valakié, amit birtokolni lehet. Csakhogy Tollefsen (egyetértésben például Ryle-lal, 1949) szerint amit az „elme” megnevez vagy jelöl, ha megjelöl egyáltalán bármi hasznosat, ${ }^{178}$ akkor az nem más, mint kognitív folyamatok, diszpozicionális állapotok, stb. összessége. A „kié?” kérdésre tehát nem kell válaszolni: ha valakié egyáltalán, akkor a csoporté (Tollefsen 2006, p. 147). Maguk a folyamatok, ha megfelelöen kapcsolódnak össze, még alkothatnak egyetlen kognitív rendszert.

A másik ellenvetés a hiányzó kválét támadja. Tollefsen e tanulmányában csupán lábjegyzetben említi, hogy a szöveg egyik elbírálója azt nehezményezi, hogy a kérdés nem az, vajon a csoportelme rendelkezik-e magyarázati erővel (magyarán, érdemes-e úgy tekinteni, mintha létezne kollektív elme), hanem az, hogy több elme ténylegesen konstituál-e elmét. „Ennek igazsága egyetlen tényezőn múlik: képes a kollektív entitás érezni? Ha nem, akkor nem elme" (Tollefsen 2006, p. 147. Kiemelés tölem.). Egy hasonló aggály visszhangzik Rupert (2004)-nél is, aki az intencionalitás szükséges feltételének tartja a fenomenális állapotokat; és mivel csoportok nem rendelkezhetnek fenomenális karakterrel, ezért intencionalitással sem - ebből kifolyólag pedig elmével sem.

\footnotetext{
${ }^{176}$ Azt, hogy az elme szükségképp neurális alapon realizálódna, Tollefsen épp a kiterjedt elme tézisével látja aláásódni; ez nyitja meg számára a csoportelme felé vezető utat, így azt az ellenvetést, miszerint „elmék a fejekben vannak, egy csoportnak pedig nincs feje, így elméje sem lehet” ennek segítségével eleve elhárítja.

${ }^{177}$ Azért csak „kvázi”, mert a karteziánus démon nem teljes erejében maradt fenn, hanem átalakulva.

${ }^{178}$ Emlékezzünk Clark végül meg nem jelent tanulmányára, amelyet Prinz-cel közösen írt, és amely ezen állásponttal szimpatizál.
} 
Block „Kína mint elme” gondolatkísérlete épp erre épít: a hiányzó kváléra. Említés szintjén már rámutattam, hogy az érvelés még ebben az esetben sem konklúzív, pedig a kikötés szerint tökéletes funkcionális egyezés van a neuronok és az emberek között. Vegyük észre, hogy a kollektív elme egyes elemei nem úgy kapcsolódnak össze, hogy egy konkrét agyat imitáljanak, hanem az alapján, ahogy a kiterjedt elme különböző elemei összekapcsolódnak. És amint a kiterjedt elme eredeti koncepciójánál és az arra érkező ellenvetéseknél láttuk, nem feltétlenül szükséges, hogy a kiterjedt elme izomorfiát mutasson internális folyamatokkal. Így például ha Otto rendelkezik is kváléval, a notesznek nem kell; ha megfelelően integrálódik a rendszerbe funkcióját tekintve, akkor ennyi elégséges ahhoz, hogy kognitív rendszer részét képezze. Továbbá egy kognitív folyamatot nem az tesz kognitívvá, hogy van fenomenális karaktere: a legtöbb kognitív folyamatnak feltehetően nincs. Tehát az, hogy a csoportelmének sincs (ami valóban felettébb valószínü), még nem jelenti azt, hogy ne lehetne elmének tekinteni, hiszen attól még kognitív folyamatok (megfelelő módon strukturált) összessége.

Tollefsen azt mondja, hogy korai lenne afelöl ítélni, hogy egy ilyen csoportelme feltételezése valóban magyarázati előnyt jelent-e, vagyis gazdagabb és a jelenségeket könnyebben magyarázó leírásokat eredményez-e; épp ezért korai elvetése felelőtlenség lenne (Tollefsen 2006, p. 149). Clark és Chalmers is beszél arról az eredeti tanulmányban, hogy Otto és a notesz mint hibrid rendszer egyszerübb leírás, mintha inputok és outputok hosszú sorának tekintenénk két elem között; és így a „valóságot inkább az ízületeinél szeleteli fel” (Clark és Chalmers 2010, p. 30).

„Példaként a döntéshozás egy olyan folyamat, amely magába foglalja a probléma azonosítását, alternatív megoldások kigondolását, az alternatív megoldások kiértékelését, majd a végső döntés meghozását azt illetően, hogy miként viselkedjünk. Ezen tevékenységek mindegyike elvégezhető az individuum mint elkülönülő kognitív egység által, de talán még hatékonyabban individuumok csoportjaként, amely koordinált módon viselkedik. Szélsőséges esetben csoportok olyan módon integrálódhatnak, és bármely egyes tag hozzájárulása olyan parciális lehet, hogy szó szerint azt mondhatjuk, hogy a csoportnak elméje van olyan értelemben, mint az individuumoknak is" (Wilson, 1997, p. 131). ${ }^{179}$

\footnotetext{
179 Továbbá Wilson a csoportszelekció folyamata révén elképzelhetőnek tartja, hogy "az individuumok megszünhetnek önálló döntéshozóként funkcionálni, és egy csoportszintü kognitív struktúra részévé válhatnak, melyben az alternativák generálásának, értékelésének és kiválasztásának feladatai eloszlanak a csoport tagjai közt” (Wilson 1997, p. 358). Evolúciós folyamatok (ha létezik a csoportszelekció, ami azért vitatott) jelenthettek nyomást a csoportszintű kognitív struktúrák felé. Erről bővebben lásd "A társas kiterjedt elme” fejezetet.
} 
A csoportelme koncepciójának lényege abban áll, amint az a fenti idézetből is látszik, hogy mivel ugyanazon funkciók és funkciók rendszerei realizálódhatnak az individuális elmében, mint egy szervezett csoportban, ezért a csoportok is az ágencia locusai, tehát tekinthetők úgy, mintha elmével rendelkeznének. A csoportelme filozófiájában nincs módunk jobban elmerülni, azt azonban jelezném, hogy Tollefsen joggal mutat rá, hogy Clark és Chalmers gondolatmenete egyrészt újabb konceptuális utat nyit a csoportelme felé, másrészt arra, hogy a szerzőpáros már-már szinte magától kínálkozik szövetségesként, hiszen tulajdonképpen ugyanolyan, vagy nagyon hasonló támadások érik mindkét elképzelést.

Hutchins (1995) Wilsonhoz nagyon hasonlóan közelít a problémához. Az olyan komplex problémamegoldási feladatokat, amilyen egy repülőgép vagy egy hajó navigációja, szintén nem az individuum felől látja vizsgálandónak. Azt állítja, hogy vannak olyan kognitív teljesítmények, ahol az elemzés egységét ki kell terjeszteni több kognitív ágensre és az abban részt vevő artefaktumokra (ezzel pedig túllép a tollefseni „tiszta” kollektív elmén), máskülönben nem lehet kielégítő magyarázatot adni rájuk. Ilyenkor a reprezentáció és komputáció eloszlik a rendszerben. Senki nem rendelkezik a problématér és információk egészével. A fókusz az individualitásról a kollektivitásra kerül át (csoportelme), és ezáltal pedig maga a kollektívum is vizsgálható lesz mint önálló jogon vett kognitív ágens. Ennek újabb, nyilvánvalóbbá váló példái lehetnek az eloszlott, kollektív kognícióra azon „big science” természettudományos projektek, ahol tudósok akár ezrei dolgoznak konvergáló problémákon és nyilvánvaló, hogy a specializáció mértéke miatt senki sem képes átlátni a munka egészét (Arnau és mtsai. 2014).

Magának a kognitív összekapcsolódásnak a módja nem különbözik sem Alexis és a jogrendszer között Gallaghernél, sem Inga, Otto és a tetszőleges számú többi ember között Tollefsennél, sem a repülőgép artefaktumai és az azt irányító emberek között Hutchinsnál. Amiben Hutchins megközelítése különbözik (habár Tollefsen is tesz lépéseket ebbe az irányba, sőt tulajdonképpen Gallagher is), az a perspektíva.

Hutchins az eloszlott kogníció (distributed cognition) koncepciója felöl érvel, melyet azonban komplementernek tart a kiterjedt elmével: a különbséget a fókuszban látja. Míg Clark az individuumra és annak kognitív összekapcsolódásaira koncentrál kisebb tér- és időbeli skálán, addig Hutchins távolabbi perspektívából vizsgálódik. Az elméletek remélt komplementeritása ellenére felmutathatók feszültségek és különbségek, ezeket vesszük most szemügyre.

$\mathrm{Az}$ eloszlott kogníció még decentralizáltabb, mint a kiterjedt elme: utóbbi középpontjában mégiscsak az organizmus áll, legalábbis a „bentről kifele” terjedő elmék 
esetében, tehát a klasszikus kiterjedt elméknél; a „kívülről befele” terjedés esetében, tehát a szociális és transzformatív kapcsolatoknál kevésbé. Ez a megkülönböztetés még akkor is jogos, ha a kiterjedt elme decentralizáltabb, mint az internalista megközelítések. Maga Clark is sokszor érvel úgy, hogy a kiterjedt rendszerek központjának hiánya nem kell, hogy problémát jelentsen a kiterjedt elme koncepciójával szimpatizálók számára: hiszen az elme maga is decentralizált, központi döntéshozó nélkül (legalábbis egy olyan „homonculus” értelmében, aki a karteziánus színházban ül, és inputok alapján outputokat generál). Hutchins a magasabb szerveződési szint felöl közelít: a kogníciónak nincs a priori felismerhető centruma, az mindig egy eloszlott kognitív hálózat részeként jelenik meg egy kognitív ökológiában, a mentálist formáló kulturális gyakorlatokkal, soha nem vákuumban. Továbbá és itt nincs feszültség az eloszlott és kiterjedt megközelítések között - Hutchins számára a kognitív rendszer „határait” az információáramlás relatív sürüsége határozza meg. ${ }^{180} \mathrm{~A}$ kognitív rendszerek demarkációja tehát a parttalan metafizikai viták helyett empirikusan meghatározható, még ha a határ fluid és állandóan változik is. A rendszernek vannak sürübb és kevésbé sürü részei: „fraktális” (Hutchins 1995, p. 3).

Hutchins a centralitáson túl a következő különbséget emeli ki: az elme a kiterjedt elme irodalma alapján bizonyos esetekben kiterjed, bizonyos esetekben pedig nem, tehát a kiterjedt elme egy alcsoportját jelöli ki a kogníciónak. Mindez pedig még mindig az elme mint tartály metaforában lel gyökereket. Ez bizonyára igaz a kiterjedt elme első és második hullámára, tehát a klasszikus esetekben, ami viszont a szociális és transzformatív kognitív összekapcsolódást illeti, már kevésbé, vagy egyáltalán nem érvényes.

Ezzel szemben az eloszlott kogníció nem alfaja a kognitív folyamatoknak, hanem perspektíva, melyből minden kognitív folyamat vizsgálható (Hutchins 1995, p. 3). Itt tehát megnyílik egy átjáró a kiterjedt és eloszlott megközelítések között, melyek így valóban kompatibilisnek és komplementernek mutatkoznak, kifejezetten a szociális és transzformatív kiterjedéseket is fígyelembe véve. Mindkét megközelítés abban érdekelt, hogy a környezet (materiális, szociális és kulturális) interakcióit vizsgálják és ebbe az irányba tolják a kognitív tudományos vizsgálódások és filozófiai elméletek magyarázatait.

A fentiekböl következik, hogy (egy közös problémán dolgozó) csoport vagy intézmény is vizsgálható kognitív rendszerként. Például: egy individuum ugyanazon séma mentén old meg problémákat, mint a tudósközösség (Popper 1998 alapján: $\mathrm{P}_{1} \rightarrow \mathrm{KE} \rightarrow \mathrm{HK}$

\footnotetext{
${ }^{180}$ Ha azonban az információáramlás sürüsége jelöli ki a rendszerhatárokat, akkor az is lehetséges, hogy egy agyon belüli állapotok vagy folyamatok nem mindegyike tartozik hozzá az agy által realizált elméhez. Tehát feltehetően ez sem teljesen megnyugtató álláspont.
} 
$\rightarrow \mathrm{P}_{2}$ Probléma $\rightarrow$ Kísérleti elmélet $\rightarrow$ Hiba kikuszöbölése kritika révén $\rightarrow$ Új probléma.) A maga belső szabályaival, hiteivel, eszközeivel, adattárolóival, kommunikációs rendszereivel a tudomány mint intézmény is vizsgálható lesz mint kognitív rendszer, mellyel szemben a felhozott ellenvetések éppen azért nem müködnek, amiért hatástalanok a klasszikus kiterjedt elmével szemben is. Nincs centrum, és nincs akié: maga a rendszer kognitív.

Ha az ilyen mértékben kiterjedt rendszerek kognitív jellegét nehezen fogadjuk el, akkor Dennett intencionális alapállása talán segítségünkre lehet.

\subsection{Az intencionális alapállás nézőpontja}

Dennett a következőt érti intencionális alapálláson:

„Az intencionális alapállás azon statégia, amikor egy entitás (személy, állat, artefaktum, bármi) viselkedését úgy interpretáljuk, mintha racionális ágens lenne, aki úgy irányítja «cselekedetei» «kiválasztását», hogy «fígyelembe veszi» «hiteit» és «vágyait»"(Dennett, 2011, p. 1).

Meglehet, hogy egy sakkgép nem rendelkezik olyan értelemben vett mentális állapotokkal (hitekkel, vágyakkal), mint egy ember, ugyanakkor, amikor ellene játszunk, mégis csak az a legcélravezetőbb, ha feltételezzük, hogy úgy tesz lépéseket, hogy az megfelel annak a „vágyának”, hogy nyerni „akar”, és annak a „hitének”, hogy az adott lépés közelebb juttatja ehhez. Így tudjuk a leginkább megjósolni, értelmezni és magyarázni, hogy milyen lépéseket fog tenni.

Dennett három interpretációs alapállást különböztet meg, amelyekkel a viselkedést meg lehet jósolni: a fizikait, a tervezésit és az intencionálist. Minden létező dolog ki van téve a fizika törvényeinek, így elvileg minden magyarázható és értelmezhető ebből az alapállásból, sőt, sok mindenre (az élettelen és nem artefaktum-jellegü dolgokra) csak ezt az interpretációs stratégiát lehet alkalmazni. (Például mit „tesz” az alma, ha leejtem, vagy ha kinn hagyom az asztalon hetekre.)

A tervezési alapállást olyan tárgyakra érdemes alkalmazni, amelyek valamilyen funkció ellátására lettek tervezve (például vekker, sakkgép). Nem túl nagy rizikó azt jósolni, hogy amennyiben a vekkert bizonyos módon beállítom, akkor az adott időpontban jelezni fog. Tehetem mindezt anélkül, hogy a konkrét fizikai felépítéséröl bármi fogalmam lenne: feltételezem (és általában joggal, kivéve, amikor elromlik, vagy át akarnak ejteni), hogy 
valamilyen fizikai mechanizmus alapját képezi ennek a funkciónak, mely miatt a vekker képes úgy viselkedni, ahogyan. Elvileg a fundamentális fizika leírásai alapján is tehetnék ugyanilyen jóslatot, csak ez kivitelezhetetlenül nehézkesebb lenne.

Az intencionális alapállás a tervezési alapállás alfaja, amely tárgya azon tervezett ágenseknek, amelyek rendelkeznek hitekkel, vágyakkal és annyi racionalitással, hogy ezeket összeegyeztetve, ezeknek megfelelően cselekedjenek. Ahhoz, hogy relatív bizonyossággal meg tudjuk jósolni a sakkprogram lépéseit (legalábbis, hogy a legrosszabb lépéseket kizárjuk), nem kell értenünk a programozáshoz, és az áramkörökben mozgó elektronokat sem kell ismernünk. Amikor az emberek egymás viselkedését értelmezik és próbálják megjósolni, akkor szintén ezt az alapállást veszik fel, a fizikai és a tervezési alapállások pedig szintén zárójelbe kerülnek. (Sőt, valójában senki nem is lenne képes ilyen leírását nyújtani még a legegyszerübb emberi döntésnek sem. Ez épp az elmetudományok naturalizációs törekvése, hogy képes legyen.)

De a termosztátok (hogy a leghírhedtebb példát is említsük), a kutyák, medúzák, fák, mohák, emberek, robotok, programok mentális állapotai közt vajon hol húzható meg a határ? Kik azok, akik ténylegesen rendelkeznek hitekkel és vágyakkal, és kik azok, akiknél ezek pusztán származtatottak, és csak „úgy viselkednek, mintha”? Ez a dolgozatból is ismerősen hangozhat, hiszen a kiterjedt rendszerek externális elemei a kritikusok szemében éppen hogy nem voltak „eredetiek”, ,igaziból mentálisak”, stb. Több szerzőnek gyökerezett az eredeti és származtatott intencionalitás problematikájában az ellenvetése. ${ }^{181}$ Dennett szerint azonban ez elhibázott kérdés.

Az intencionális alapállás alapvetően teórianeutrális ${ }^{182}$ : jóslatokat és magyarázatokat egyaránt képes adni emberek, egysejtüek és nanobotok viselkedésére. Működik anélkül, hogy megválaszolnánk a kérdést, hogy „,a makromolekula tényleg replikálni akarja-e magát?” (Dennett, 2011, p. 9.) A „tényleg” és „úgy csinál, mintha” közti különbség irreleváns, és Dennett ezért tartja elhibázottnak a fenti kérdést. Ha valami úgy viselkedik, mintha, akkor az valójában is az.

És bár Dennett elsősorban általában embereknél kisebb rendszerekre használja az intencionális alapállást, ez nagyobb, komplexebb szerveződésekre is alkalmazható lehet, így akár a kiterjedt, eloszlott, az inter- és szupraperszonális kognitív rendszerekre is, amilyenek a

\footnotetext{
${ }^{181}$ Lásd "Ellenvetések" alfejezetet.

182 És így is került eredetileg megfogalmazásra (Dennett, 1971), de sok szerző ezt az interpretációs eszközt a genuin hitek elméletének tartotta, és a kezdetekről fogva vitában is áll vele. Ami, Dennett filozófiáját ismervén egyébként érthető is, hiszen, ha az intencionális alapállás maga teórianeutrális eszközként nem is foglal állást a „genuin" hitekkel szemben, Dennett viszont igen.
} 
csoportok vagy intézmények. Ezzel szemben Dennett is aligha találna kivetnivalót, ugyanis:,Bármi, ami hatékonyan és gyakran bejósolható az intencionális alapállásból, az definició szerint intencionális rendszer" (Dennett, 2011, p. 1. Kiemelés tölem.).

A csoportok és intézmények besorolhatók ebbe a kategóriába, és innentől kezdve Dennett érvei, melyeket az „,igazi”, „genuin” mentális állapotok megkülönböztetése ellen hoz, felhasználhatók lesznek a dolgozat gondolatmenetének megtámogatására is. Példa: ha a tudósközösség észlel egy anomalisztikus jelenséget, mely sehogy sem illeszkedik uralkodó elméletekbe, akkor beindul a séma: $\mathrm{P}_{1} \rightarrow \mathrm{KE} \rightarrow \mathrm{HK} \rightarrow \mathrm{P}_{2}$, és a közösség addig nem nyugszik, amíg az anomália megmagyarázhatóvá nem válik. A jóslat müködik, tehát a tudósközösség intencionális rendszer. Intézmények, szervezett csoportok tehát alkothatnak kognitív rendszereket. De hogy jutunk mindebből egy globális elméig?

A „Társas kiterjedt elme” fejezet vége felvetette, hogy egy globális mértékü szuperorganizmikus „összeugrás” valószínüleg egy bolygóközi támadás révén valósulhatna meg, ezzel pszichológiai motivációt nyújtva egy kognitív (és pszichológiai) megastruktúra létrehozásához. De helyezkedjünk most a támadók szemszögébe, bárhonnan jöjjenek is, ahogy ürhajóikról a Földet nézik a távolból. Ha le akarnak igázni minket, kénytelenek lesznek az intencionális alapállásból megtenni mindezt, hiszen legyen bármily fejlett is a technológiájuk, feltehetően nem lennének képesek a fizikai vagy a tervezési alapállásból megjósolni, hogy milyen ellenlépéseket fogunk tenni. De ha képesek lennének is: mi értelme lenne, ha az intencionális alapállásból kényelmesebben, egyszerübben és gyorsabban megtehetik ugyanezt? Nem érdekes, hogy milyen konkrét implementációs módon áll össze az emberiség a maga megszámlálhatatlan intézményével együtt, sok szintböl és még több szerteágazó feladatkörrel, mégis egy célt szolgáló álló funkcionális egésszé; hogy milyen döntéshozási szervek alakulnak, hogy alakul a munkamegosztás, milyen fegyvereket vet be stb., akár egy szervezet: az azonban biztos, hogy az ürből nézve leginkább a bolyukat védő hangyáknak tűnnénk, vagy akár egyetlen lénynek egységes kognícióval. És mivel az intencionális alapállásból megjósolható ennek az entitásnak a viselkedése (védeni fogja magát, támad, menekülni próbál, stb.), ezért intencionális rendszer: ezzel pedig eljutottunk a globális elméig mint konceptuális lehetőségig. Természetesen ennek az elmének lesznek aktívabb és kevésbé aktív részei: ha valamiféle szavazás módján szervezzük magunkat (erre a globális katasztrófa küszöbén, azt hiszem, kevés az esély), akkor viszonylag sok ponton fog egyszer egy pillanatra aktiválódni a hálózat, hogy utána centrálisabb helyekre delegálja a döntéshozást. (Utána az egyedek más módon is támogathatják e centrálisabb helyek 
müködését, melyek pedig még centrálisabb helyek felé továbbítanak információkat, míg végül, gondolom, az Egyesült Államok Oroszországgal és Kínával kommunikálva és kooperálva kilövi a nukleáris tölteteit, vagy valami hasonló.) Meglehet, sőt, szinte bizonyára, sok rész egyáltalán nem venne részt ennek az elmének a müködésében. Vagy azért, mert a modern civilizációtól érintetlenül élnek (ők egyszerűen nem részei az elmének), vagy aktívan semmilyen szerepet nem vállalnak a döntéshozásban. Ez sem probléma: az individuális elménkben sem egyformán aktív minden rész egy adott tevékenység során. Hutchins (1995) nyomán az információáramlás relatív sürüségével határozhatjuk meg legjobban az elme határait és fontosabb gócpontjait.

Az alfejezet gondolatmenetét összefoglalva: a kiterjedt elme keretei közé beférnek teljes intézmények is, sőt, intézmények sokaságai is. Ha az elemek megfelelően kapcsolódnak össze, akkor egy globális elmét is létrehozhatnak, mely, ha nem is aktuális, de konceptuális lehetőség. Ezáltal pedig az, hogy a kiterjedt elme eredeti koncepciójából következik a globális elme, nem gyengíti az eredeti elméletet. 


\section{A kognitív kiterjedések taxonómiája}

\begin{tabular}{|c|c|c|c|}
\hline A kiterjedés neve & $\begin{array}{c}\text { Merev (klasszikus) } \\
\text { 1. és 2. hullám }\end{array}$ & Társas & $\begin{array}{c}\text { Transzformatív } \\
\text { 3. hullám }\end{array}$ \\
\hline Irány & $\begin{array}{l}\text { kifelé (augmentáció) } \\
\text { befelé } \\
\text { (internalizáció) }\end{array}$ & (inkább) befelé & (föleg) befelé \\
\hline $\begin{array}{l}\text { A kognitív } \\
\text { összekapcsolódás } \\
\text { gerince }\end{array}$ & $\begin{array}{l}\text { „A” kritériumok } \\
\text { (paritás és } \\
\text { komplementaritás } \\
\text { egyaránt) }\end{array}$ & $\begin{array}{l}\text { „C” kritériumok } \\
\text { vagy szociális } \\
\text { identitásfolyamatok }\end{array}$ & $\begin{array}{l}\text { „C” kritériumok } \\
\text { vagy transzformatív } \\
\text { összekapcsolódás }\end{array}$ \\
\hline Példa & $\begin{array}{l}\text { Augmentáció: Otto } \\
\text { és notesze, } \\
\text { biotechnológiai } \\
\text { implantátum. } \\
\text { Internalizáció: Otto } \\
\text { megtanulja a } \\
\text { másodfokú egyenlet } \\
\text { megoldóképletét. }{ }^{183}\end{array}$ & $\begin{array}{l}\text { Otto olyat művel } \\
\text { egy tüntetésen, amit } \\
\text { magától soha nem } \\
\text { tenne. } \\
\text { Otto jelentős } \\
\text { feszülttséget él át, } \\
\text { amikor a csoport } \\
\text { tagainak nyíltan } \\
\text { ellent kell mondania. }\end{array}$ & $\begin{array}{l}\text { A moken gyerekek } \\
\text { kétszer olyan jól } \\
\text { látnak víz alatt, mint } \\
\text { az európaiak. } \\
\text { Távol-keleti alanyok } \\
\text { hajlamosabbak } \\
\text { beleesni az utólagos } \\
\text { előrelátás hibájába } \\
\text { (hindsight bias). }\end{array}$ \\
\hline
\end{tabular}

Otto és a notesz a par excellence első hullámos résztvevője a kiterjedt kognitív rendszer címéért induló versenynek. Láthattuk, hogy itt a hangsúly még a paritáson és funkcionális izomorfián van. A kiterjedt elme második hullámával bekerülnek ebbe a versenybe olyan résztvevők is, melyek lényege épp a paritás és izomorfia hiányában áll, hiszen kiegészítik a már meglévő mentális apparátust: a komplementaritás a szempont. A meglévő képességek hatóköre növekszik, vagy adott esetben akár radikálisan új képesség jelenik meg. Ennek a felosztásnak álláspontom szerint nincsen tartalmi relevanciája, a második hullámos rendszerek externális elemei ugyanúgy alkothatják a kogníció metafizikai

\footnotetext{
${ }^{183}$ Valószínüleg ez is inkább transzformatív jellegű, hiszen, ha elhanyagolható szinten is, de minden tanult dolog nyomot hagy az agyon.
} 
konstitúciós bázisát. ${ }^{184}$ További fontos jellemző, hogy az externális elemek viszonylag érintetlenül hagyják az elme folyamatait; akár a LEGO darabjai, tetszőlegesen építgethetők és szétszerelhetők: merev struktúra. Elsősorban az augmentációról van szó, habár internalizációs esetek is elgondolhatók. Internalizációra példa: a mnemonikus eszközök lényege, hogy a biológiai memória fogyatékosságait ellensúlyozzák, hogy struktúrát, merevséget, belső állványzatot (scaffolding) biztosítson az eredetileg ingoványos, változékony mentális világban. Az alany egy externális modellt átfordít internálissá, melyet, mint kvázi különálló modult képes használni. A memóriamüvész dönthet úgy, hogy nem ilyen módon tárolja az információt, és akkor a különböző memóriával kapcsolatos pszichológiai szabályszerü folyamatok hatással lesznek arra: ha viszont alkalmazza, akkor azok tulajdonképpen épp annyira lesznek statikusak, diszkrétek, kontextusfüggetlenek, stb., mint a noteszbe leírt szavak. Azért lehet érdemes ezt is kiterjedésnek tartani, mert egy eleddig nem létező, augmentatív „,modul” jelenik meg, még ha ez internális is. Az internalitást leszámítva minden másban hasonlít a notesz esetéhez. Ugyanakkor a kiterjedt elme első két hullámában az elme főképp „kifelé” terjed. Ha az időbeliség dimenziója felől vizsgálódunk, akkor azt mondhatjuk, hogy ezek a kiterjedések opportunisztikusak, és az externális elem kognitív hatása azonnal megszünik, amint megtörténik a különválás.

Az összekapcsolódás két másik fajtájához akkor jutunk el, ha a „kiterjedés” iránya megfordul: olyan hangsúlyeltolódás következik be, amely az internális elemet szinte passzívvá teszi, mely ki van szolgáltatva az externális elemek müködésének. Amint azt az eredeti „A” kritériumokkal kapcsolatban láthattuk, nem összeegyeztethetőek a paritási elvvel, így tehát egyrészt Clark és Chalmers eredeti gondolatmenetéből is következik ezek megváltoztatásának igénye, másrészt vannak olyan szociálpszichológiai jelenségek, amelyek könnyen illeszkednek a kiterjedt elme keretéhez (sokkal jobban, mint az internalista felfogásokhoz). Habár a kétirányú interakció olykor fennál az ilyen fajta kiterjedések során is, az externális elem hatásai a mérvadóbbak. Így nem augmentációról van szó, hanem inkább befolyásolásról, a szó nem (feltétlenül) negatív értelmében. A társas kiterjedt elme kognitív összekapcsolódásának gerinceként a „C” kritériumokat és a szociális identitásfolyamatokat neveztem meg.

\footnotetext{
${ }^{184}$ Persze ettől még lehet jelezni, és akár szükséges is lehet egy olyan nomenklatúra, amely meg is teszi ezt a különbséget: pl. Bach-y-Rita és mtsai. (2003) is különválasztja az augmentációt és szubsztitúciót.
} 
Le Bon lélektani tömege és az ebben feloldódott Otto esetében van némi heurisztikus ereje annak a metaforának, miszerint az elme „lyukacsos” vagy „ereszt”. ${ }^{185}$ A ,kiterjedésnek” más az iránya. Nem az elme terjed „ki” a világba, sokkal inkább a világ terjed „,be” az elmébe.

Vegyük immár többedjére a „C” kritériumokat, melyek alapján Otto és a tömeg kognitív rendszert képez.

(1) Az (internális és externális) elemek között kétirányú interakció áll fenn.

(2) Minden elem aktív okságilag.

(3) A rendszer együtt úgy irányítja a viselkedést, ahogy a kogníció általában.

(4c) Ha megváltoztatjuk az externális elemet, megváltozik az alany viselkedése, mintha egy agyrészét változtattuk volna meg.

Bár mindegyik kritérium teljesül, találunk némi aszimmetriát az internális és externális elem oksági hatékonysága közt. Otto maga is része a tömegnek és fenntartja azt a viselkedésével: ugyanakkor a tömeg nagyobb mértékben képes befolyásolni Ottot, mint fordítva. Otto például nem képes egymaga lenyugtatni a felhergelt tömeget, a tömeg szétszéledése azonban képes lenyugtatni Ottot.

$\mathrm{Az}$ eredeti augmentációs példák során az externális elemek szinte LEGO-ként építhetők hozzá a meglévő kognitív struktúrához, az utóbbi példa során azonban az ehhez csatolt külső elem visszahat a kogitáló alanyra, adott esetben akár nagyobb mértékben is, mint fordítva. Itt az elme mint „szivacs” kerül felmutatásra.

Az effajta szivacsos összekapcsolódásra ellenvetésként fel lehet hozni egy különbséget, mely az eredeti augmentációs példáknál valóban nem kerül szóba. Történetesen azt, hogy Otto szándékosan, tudatosan használja a noteszt: amikor viszont egy tüntetéshez csatlakozik, az olyan viselkedésmódokat válthat ki belöle, melyekröl eleinte nem tud, és amelyeket nem szándékozott volna. (Például egy autó felborítása.) Az erre a különbségre való hivatkozás akkor állná meg a helyét, ha az internális kognitív folyamatainkra is igaz lenne, hogy feltétlenül szándékosak vagy tudatosak. Csakhogy egy kognitív folyamatnak előre nem látott és így nem szándékos következményei is lehetnek, illetve a legtöbb kognitív folyamat eleve nem tudatos és nem is tudatosítható. És mivel az internális folyamatokra ezek nem állnak, így az ilyen hibrid kognitív rendszerekre sem kell, hogy érvényesek legyenek. Otto és a tömeg tehát képezhet egyetlen kognitív rendszert.

\footnotetext{
185 Az „eresztés” metaforája itt nem abban az értelemben értendő, ahogy például Dartnall (2005) teszi: ő bizonyos, a külvilágban végrehajtott operációk esetéröl beszél, melyeket végrehajthatunk, modellezhetünk internálisan is, így jutva episztemikus újdonsághoz.
} 
Ami azonban a merev (klasszikus) és társas kiterjedések különböző összekapcsolódásaiban még mindig hasonlít az, hogy a hatás lehet majdnem azonnali. Ha Otto elhagyja a füzetét, az olyan, mintha az agyrésze sérült volna; ha pedig a le boni pszichológiai tömeget hagyja el, mintha beavatkoztak volna a releváns agyrészébe. A társas kiterjedésnek van azonban egy láthatatlanabb, állandó jellegü kapcsolata is, amire példaként Heidegger akárkijét hoztuk fel: identitását tekintve a tipikus emberi egyed már eleve mindig csoportokhoz tartozik, amelyek meghatározzák internális folyamatait, így valójában akkor is másokkal van (mit-Sein), amikor egyedül van. A társas kiterjedésnek ez az utóbbi, láthatatlan fajtája lassú és transzformatív is, mely nélkül nem is lehet elképzelni egy tipikus emberi lényt, így inkább hasonlít a harmadik hullám transzformatív kognitív összekapcsolódásához.

A transzformatív kognitív összekapcsolódásnál a kiterjedés metaforája helyett egy másik metafora működhet nagyobb heurisztikus erővel, mégpedig az, hogy az elme szivacsos.

„Az emberi elme „ereszt”, egyrészt mert kiterjed a börön túlra, hogy externális elemeket, technológiákat és más embereket vonjon be, másrészt mert a plasztikus agyunk természetszerüleg felszív cimkéket, belső tárgyakat és reprezentációs sémákat, internalizálva és inkorporálva ilyen forrásokat, és gyakran újrahasznosítva azokat újszerű módokon” (Sutton, 2010, p. 190).

Ez az összekapcsolódás szintén „kintről” „befelé” terjed. Lényege, hogy az eredetileg kint található gyakorlatok, mémek és szokások internalizálásra kerülnek, amelyek át-, illetve eleve kialakítják (mégpedig szükségképp alakítják ki, hiszen kultúra nélkül nincs tipikus emberi egyed) az individuális mentális folyamatokat. A kultúra nemcsak tartalmat biztosít (hogy az egyedei mikröl gondolkodnak), hanem a kognitív folyamatokat is meghatározza (azt, hogy az egyedei hogyan gondolkodnak). Ez a hosszan tartó, gyakori interakció transzformatív, és konstitutívnak tekinthető abban az értelemben, hogy nélküle nem is lehetségesek mentális folyamatok.

E három kognitív összekapcsolódási fajta nem feltétlenül jár együtt. Az ember esetében együtt járnak ugyan, de ez biológiai kontingencia. Például a farkasoknál valamilyen mértékben megvalósulhat a társas kiterjedés, azonban a klasszikus kiterjedés bizonyára nem. Továbbá egy számítógép a végtelenségig augmentálhatja számítókapacitását, anélkül, hogy a szocialitás bármilyen mértékben befolyásolhatná. Úgy tủnik, hogy a harmadik hullámos transzformatív összekapcsolódás ilyen mértéke kifejezetten emberi képesség, és talán részben épp ez teszi lehetővé evolúciós sikereinket. 
Ami a globális elmét illeti, nem véletlenül nem szerepel a taxonómiában, ugyanis nem alkot egy különálló összekapcsolódási fajtát. Inkább arról van szó, hogy egyrészt mind a három összekapcsolódási fajta részt vehet benne (a társas kiterjedés kiemelten fontos szerepet játszana ebben az esetben, ugyanis szuperorganizmikus malterként motivációt biztosítana a klasszikus összekapcsolódások létrehozásához), másrészt elgondolható tisztán a klasszikus keret alapján is. Ez Clark és Chalmers maximálisan végiggondolt eredeti kiterjedése, mely következik is a gondolatmenetükböl. Annyi változtatást eszközöltem, hogy a kognitív kiterjedés vizsgálata során annak centrumából kikerült az organizmus, és egy magasabb szintről, az egész rendszert szemléltük.

Valószínüleg egyéb kognitív összekapcsolódások is elgondolhatók, amelyek valamely dimenziójuk mentén különböznek az ebben a dolgozatban kifejtettektől, és amelyek további kutatás témái lehetnek. Itt kénytelen leszek megelégedni pusztán egy ilyen lehetséges kiterjedés megemlítésével.

Lehetséges összekapcsolódás származhat például a környezetpszichológia által vizsgált területről (Dúll 2009). Ez a multidiszciplináris vállalkozás azt kutatja, hogy milyen módon alakítanak minket érzelmileg, kognitívan és viselkedésünkben a természetes és mesterséges környezeteink. Elgondolható lehet például kiterjedt kognitív rendszerként az otthonunk; ahol a számunkra értékteljes tárgyak irányítják a fígyelmünket, ilyen-olyan hangulatokat keltenek, és egyfajta szilárdságot biztosítanak annak, akik vagyunk, illetve szépen lassan formálnak is minket. Egy ilyen felállásban az interakció valóban kétirányú, hiszen a környezetemet én alakítom, cserébe az formál engem kognitív, emotív és viselkedési értelemben is. A környezetpszichológiából vett kiterjedt rendszerek (ha valóban lehetséges ezekröl így gondolkodni) azonban mindenképp hosszabb kifejtést érdemelnének.

\section{Konklúzió}

A gondolatmenet elején a mainstream kognitív tudományos elme modelljének karteziánus gyökereit mutattam ki, valamint azt, hogy ez miként jelentkezik és kulminálódik Fodor programadó modul-elméletében, mely mint kognitív atomot, egyfajta módszertani szolipszizmusban vizsgálja az elmét. Ez az elme egyrészt a külvilágtól függetlenül vizsgálható, hiszen csak input-szolgáltató szerepe van, másrészt erősen specializált moduljai 
egymástól is meglehetősen elzártak az információáramlás tekintetében. Ez a modell már az elmén belül is túl merevnek és zártnak mutatkozott, ezért különböző kísérleti eredményektől motiváltan, melyek az embodied és embedded téziseket is inspirálták, a test és külvilág folyamatai felé is érdemes volt kinyitni egy árnyaltabb kép érdekében. Így jutottunk a kiterjedt elme koncepciójához, mely radikalizálja a kapcsolatot elme és külvilág között, utóbbi folyamatait konstitutívnak tartva előbbi folyamataiban. A Clark és Chalmers által előadott eredeti gondolatmenet bemutatása, és az ellene felhozott ellenvetések áttekintése során az utóbbiak nagyrészt hatástalaníthatónak bizonyultak. A dilemma, mely elé a gondolatmenet állít minket, intuícióinkat mindenképp nehéz helyzetbe hozza: vagy egy túl szűk, vagy pedig egy túl tág elme-képet kell elfogadnunk. Ebben a dolgozatban az utóbbi mellett tettem le a voksot, mert bár első ránézésre kontraintuitívabbnak tűnhetnek a hibdrid kiterjedt rendszerek, az elmét vizsgáló tudományok számos eredménye alapján egy olyan én-kép kezd körvanalazódni, mely mégis inkább ehhez illeszkedik jobban.

A kiterjedt elme általam elfogadhatónak tünő elméletében a kognitív összekapcsolódás fogalma kulcsfontosságú. Clark és Chalmers az „A” és „B” kritériumokat adja meg az összekapcsolódás gerinceként, azonban a „B” kritériumokat a paritási elv alapján - mely az externális és internális elemek egyforma megítélését írja elő - ad hocnak találtam, ezért elvetettem. A paritási elv szellemében az „A” kritériumokon is egy kisebb, de annál jelentősebb változtatást eszközöltünk, mely a kognitív összekapcsolódás két másik fajtáját is lehetővé tette: a társas és transzformatív összekapcsolódásokat. Ezen rendszerek esetében a hangsúly sokkal inkább az externális elemre kerül, a „kiterjedés” iránya megfordul. Fontos kiemelni, hogy az „A” kritériumok megváltoztatása - állításom szerint - következik az eredeti gondolatmenetből is. Ezek után igyekeztem explikálni e különböző kiterjedéseket, megtámogattam őket kutatási eredményekkel, továbbá kiemeltem néhány általam fontosnak tartott aspektusukat. A dolgozat utolsó részében a globális elme konceptuális lehetőségéig jutottunk, melyet a klasszikus gondolatmenet elfogadható következményeként mutattam be.

Amellett, hogy a kiterjedt elme hipotézis eredeti koncepciója és a kifejtett kognitív összekapcsolódások elfogadhatósága mellett érveltem, igyekeztem az ezek mögött meghúzódó viszony- és következményrendszert is explicitté tenni. Ebből az a következtetés adódott, hogy ha egy egyszerü noteszt beengedünk a mentális világba, akkor más embereket, csoportokat, intézményeket, a kultúra szellemi termékeit, gyakorlatait, normáit, stb. is kénytelenek leszünk beengedni. Ez pedig további segítséget nyújthat az eredeti kiterjedt elme hipotézis által elénk állított dilemma eldöntésében: a túl kicsi és túl nagy elmék közötti választásban. 


\section{Felhasznált irodalom}

Adams, F. és Aizawa, K. 2001. The bounds of cognition. Philosophical Psychology, 14/1, 4364.

Adams, F. és Aizawa, K. 2008. The Bounds of Cognition. Malden, MA, Blackwell.

Adams, F. és Aizawa, K. 2010. Defending the bounds of cognition, In R. Menary (ed.) The Extended Mind, Cambridge, MA, MIT Press.

Allport, F. 1924. Social psychology. Boston, Houghton Mifflin.

Alsberg, B. K. 2012. Is sensing spatially distributed chemical information using sensory substitution with hyperspectral imaging possible? Chemometrics and Intelligent Laboratory Systems, 114, 24-29.

Ambrus, G. 2013. A gondolat természete: intuicionizmus vagy szimbolizmus? In Ambrus G. (ed.) Filozófiai intuíciók - filozófusok az intuícióról. L'Harmattan, Budapest.

Anderson, C. és Brown, C. E. 2010. The functions and dysfunctions of hierarchy. Research in Organizational Behavior, 30, 55-89.

Arnau, E., Estany, A., del Solar R. G., és Sturm, T. 2014. The extended cognition thesis: Its significance for the philosophy of (cognitive) science, Philosophical Psychology, 27/1, 1-18.

Arnett, J. 2008. The neglected 95\%: Why American psychology needs to become less American. American Psychologist, 63/7, 602-14.

Asch, S. E. 1956. Studies of independence and submission to group pressure: a minority of one against a unanimous majority. Psychological Monographs, 70/9, 1-70.

Bach-y-Rita, P. 1972. Brain mechanisms in sensory substitution. New York, Academic Press.

Bach-y-Rita, P. 2002. Sensory substitution and qualia. In A. Noe \& E. Thompson (eds.), Vision and mind. Cambridge, MA, MIT Press, 497-514.

Bach-y-Rita, P., Tyler, M. E., Kaczmarek, K. A., 2003 Seeing with the Brain, International Journal of Human-Computer Interaction, 15/2, 285-295.

Barabasi, A. L. 2003. The New Science of Networks. Artificial Societies and Social Simulation, 6.

Bargh, J. A., Chen, M. és Burrows, L. 1996. Automaticity of social behavior: Direct effects of trait construct and stereotype activation on action. Journal of Personality and Social Psychology, 71/2, 230-244.

Baron-Cohen, S. 1996. Mindblindness: An essay on autism and theory of mind. Cambridge, MA, MIT Press.

Barresi, J. és Martin, R. 2011. History as Prologue: Western Theories of the Self. In Gallagher, S. (ed.) The Oxford Handbook of the Self, Oxford University Press.

Bascom, W. R. 1953. Folklore and anthropology. The Journal of American Folklore, 66, 283- 
290.

Bassili, J. N. és Provencal, A. 1988. Perceiving minorities: a factor-analytic approach. Personality and Social Psychology Bulletin, 14, 5-15.

Bassolino, M., Serino, A. Ubaldi, S. és Ládavas, E. 2010. Everyday use of the computer mouse extends peripersonal space representation. Neuropsychologia, 48/3, 803-811.

Beer, R. D. 1995. A dynamical systems perspective on agent-environment interaction. Artificial Intelligence, 72, 173-215.

Berger, P. L. és Luckmann, T. 1966. The social costruction of reality: A treatise in the sociology of knowledge. London, Penguin Books.

Bernhardt, P. C., Dabbs, J. M., Fielden, J. A., és Lutter, C. D. 1998. Testosterone changes during vicarious experiences of winning and losing among fans at sporting events. Physiology and Behavior, 65, 59-62.

Berns, G. S., Chappelow, J., Zink, C. F., Pagnoni, G., Martin-Skurski, M. E. és Richards, J. 2005. Neurobiological correlates of social conformity and independence during mental rotation. Biological Psychiatry, 58, 245-53.

Blackmore, S. 2001. A mémgépezet, Budapest, Magyar Könyvklub, (ford: Greguss Ferenc) The Meme Machine, Oxford University Press, 1999

Blass, T. 2004. The man who shocked the world: The life and legacy of Stanley Milgram. New York, Basic Books.

Block, N. 1978. Troubles with functionalism. Minnesota Studies in the Philosophy of Science, 9, 261-325.

Block, N. 1995. The Mind as Software of the Brain. In Daniel N. Osherson, Lila Gleitman, Stephen M. Kosslyn, S. Smith és S. Sternberg (eds.), An Invitation to Cognitive Science, 2/3, Cambridge MA, MIT Press. 377-425.

Block, N. 2003. Tactile sensation via spatial perception, Trends in Cognitive Sciences, 7/7, 285-286.

Botvinick, M., és Cohen, J. 1998. Rubber Hands "Feel" Touch that Eyes See, Nature, 391, 756.

Bourhis, R. Y. és Giles, H. 1977. The language of intergroup distinctiveness. In H. Giles (ed.), Language, ethnicity and intergroup relations. London, Academic Press, 119-134.

Boutel, A. és Lewens T. 2016. Cultural Evolution and the Mind. In Kiverstein, J. (ed.) The Routledge Handbook of Philosophy of the Social Mind, Routledge

Bradac, J. J. 1990. Language attitudes and impression formation. In H. Giles és W. P. Robinson (eds.), Handbook of language and social psychology. Chichester, Wiley, 387-412.

Branscombe, N. R., Ellemers, N., Spears, R. és Doosje, B. 1999. The context and content of social identity threats. In N. Ellemers, R. Spears és B. Doosje, (eds.), Social identity: Context, commitment, content, Oxford, Blackwell, 33-58. 
Brewer, M. B. és Campbell, D. T. 1976. Ethnocentrism and intergroup attitudes: East African evidence. Beverly Hills, CA, Sage.

Brooks, R. 1991. Intelligence without representation. Artificial Intelligence, 47, 139-159.

Brown, D. E. 2004. Human universals, human nature \& human culture, Daedalus, 133/4, 4754.

Burge, T. 1986. Individualism and psychology. Philosophical Review, 94/1, 3-45.

Butler, K. 1998. Internal Affairs: A Critique of Externalism in the Philosophy of Mind. Dordrecht, Kluwer.

Buunk, B. P. és Bakker, A. B. 1995. Extradyadic sex: the role of descriptive and injunctive norms. The Journal of Sex Research, 32, 313-318.

Cacioppo, J. T., Hawkley, L. C., Norman, G. J., és Berntson, G. G. 2011. Social isolation. Annals of the New York Academy of Sciences, 1231/1, 17-22

Cacioppo, J. T., Priester, J. R., Berntson, G. G. 1993. Rudimentary determinants of attitudes: Arm flexion and extension have differential effects on attitudes. Journal of Personality and Social Psychology, 65/1, 5-17.

Candland, D. K. 1993. Feral children and clever animals: Reflections on human nature. New York, Oxford University Press.

Carruthers, M. 1990/2008. The Book of Memory. Cambridge, Cambridge University Press.

Carruthers, M. és Ziolkowski, J. 2002. General introduction. In Carruthers, M. és Ziolkowski, J. (eds.) The Medieval Craft of Memory: An Anthology of Texts and Pictures. Philadelphia, University Press, 1-31.

Carruthers, P. 2003. Moderately massive modularity. In Anthony O'Hear (ed.), Royal Institute of Philosophy Supplement. Cambridge, Cambridge University Press, 67-89.

Carvajal-Carmona, L. G., Soto, I. D., Pineda, N., Ortíz-Barrientos, D., Duque, C., OspinaDuque, J., McCarthy, M., Montoya, P., Alvarez, V. M., Bedoya, G., és Ruiz-Linares, A. 2000. Strong Amerind/White sex bias and a possible Sephardic contribution among the founders of a population in northwest Columbia. American Journal of Human Genetics, 67, 1287-1295.

Chen, R., Cohen, L. G. és Hallett, M. 2002. Nervous system reorganization following injury. Neuroscience, 111, 761-773.

Chen, S. és Bargh, J. A. 1999. Consequences of automatic evaluation: Immediate behavior dispositions to approach or avoid the stimulus. Personality and Social Psychology Bulletin, 25/2, 215-224.

Choi, I., és Nisbett, R. E. 1998. Situational salience and cultural differences in the correspondence bias and in the actor-observer bias. Personality and Social Psychology Bulletin, 24, 949-960.

Choi, I., és Nisbett, R. E. 2000. The cultural psychology of surprise: Holistic theories and recognition of contradiction. Journal of Personality and Social Psychology, 79, 890-905. 
Churchland, P. M. 1981. Eliminative materialism and the propositional attitudes. Journal of Philosophy, 78, 67-90

Cialdini, R. B. 1984/2007. Influence: The Psychology of Persuasion. New York, Harper Collins.

Cialdini, R. B., és Trost, M. R. 1998. Social influence: social norms, conformity, and compliance. In D. T. Gilbert, S. T. Fiske, és G. Lindzey (eds.), The handbook of social psychology. New York, McGraw-Hill, 151-192.

Clapp, M., Aurora, N., Herrera, L., Bhatia, M., Wilen, E., Wakefield, S. 2017. Gut microbiota's effect on mental health: The gut-brain axis. Clinics and Practice, 7/4, (https://doi.org/10.4081/cp.2017.987)

Clark, A, 2010b. Coupling, Constitution, and the Cognitive Kind: A Reply to Adams and Aizawa, In R. Menary (ed.) The Extended Mind, Cambridge, MA, MIT Press.

Clark, A. 1997. Being There: Philosophy, Cognitive Science and Parallel Distributed Processing. Cambridge, MA, MIT Press.

Clark, A. 2001. Mindware: An Introduction to the Philosophy of Cognitive Science, Oxford, Oxford University Press.

Clark, A. 2003. Natural-Born Cyborgs: Minds, Technologies, and the Future of Human Intelligence. Oxford, Oxford University Press.

Clark, A. 2004. „Author's reply” to symposium on Natural-born cyborgs, Metascience, 13/2.

Clark, A. 2005. Word, niche, and super-niche: How language makes minds matter more. Theoria, 20, 255-268.

Clark, A. 2008. Supersizing the Mind: Embodiment, Action, and Cognitive Extension. Oxford, Oxford University Press.

Clark, A. 2010a. Memento's Revenge: The Extended Mind, Extended, In R. Menary (ed.) The Extended Mind, Cambridge, MA, MIT Press.

Clark, A. és Chalmers, D. 1998/2010. The extended mind. Analysis, 58, 7-19. Reprinted in R. Menary (ed.) The Extended Mind, Cambridge, MA, MIT Press.

Clark, A. és Prinz, J. (unpublished) The absence of mind.

Cole M., 2005. Kulturális pszchológia, Budapest, Gondolat Kiadó.

Cole, M. és Scribner, S. 1974. Culture and Thought: A Psychological Introduction. New York, Wiley.

Corning, P. A. 2005. Holistic Darwinism: synergy, cybernetics, and the bioeconomics of evolution. Chicago, University of Chicago Press.

Cosmides, L. és Tooby, J. 1994. Origins of domain specificity: The evolution of functional organization. In L. A. Hirschfeld \& S. A. Gelman (eds.), Mapping the mind: Domain specificity in cognition and culture. New York, Cambridge University Press, 85-116. 
Crane, T. 1998. Intentionality as the mark of the mental. In A. O'Hear (ed.), Contemporary Issues in the Philosophy of Mind. Royal Institute of Philosophy Supplement. Cambridge, Cambridge University Press.

Csányi, V. 2018. A globális elme. Budapest, Libri Kiadó.

Daly, L. A. 2016. Anthropomorphic Sensory Augmentation: Ultrasonic Intra-Body Communication. $\mathrm{URL}=$ https://www.researchgate.net/publication/306040398_Anthropomorphic_Sensory_Augmentat ion_Ultrasonic_Intra-Body_Communication

Damasio, A. 1994. Descartes' Error: Emotions, Reason, and the Human Brain. New York, Avon Books.

Darley, J. M. és Batson, C. D. 1973. From Jerusalem to Jericho: A study of situational and dispositional variables in helping behavior. Journal of Personality and Social Psychology, 27/1, 100-108.

Dartnall, T. 2005. Does the world leak into the mind? Active externalism, "internalism," and epistemology. Cognitive Science, 29, 135-143.

Dasgubta, N. 2004. Implicit Ingroup Favoritism, Outgroup Favoritism and Their Behavioral Manifestations. Social Justice Research, 17/2, 143-169.

Dawkins, R. 1982. The Extended Phenotype. Oxford, Oxford University Press./ Dawkins, R. 1989 A hódító gén, Budapest, Gondolat Kiadó.

Dawkins, R. 1999/2005. Az önzö gén, Kossuth Kiadó, eredeti: The Selfish Gene, Oxford, Oxford University Press.

De Quervain, D. J., Fischbacher, U., Treyer, V., Schellhammer, M., Schnyder, U. Buck, A. 2004. The neural basis of altruistic punishment, Science, 305, 1254-1258.

Dehaene, S. 1997. The number sense. New York, Oxford University Press

Dennett, D. C. 1971. Intentional systems. Journal of Philosophy, 68, 87-106.

Dennett, D. C. 1987. The Intentional Stance. Cambridge, MA, MIT Press.

Dennett, D. C. 1990. The myth of original intentionality. In K. A. Mohyeldin Said , W. H. Newton-Smith, R. Viale és K. V. Wilkes (eds.), Modeling the Mind. Oxford, Oxford University Press.

Dennett, D. C. 1991. Consciousness Explained, Boston, MA, Little Brown.

Dennett, D. C. 1995. Darwin's dangerous idea: Evolution and meanings of life. New York, Simon \& Schuster.

Dennett, D. C. 1997. Kinds of Minds, New York, Basic Books.

Dennett, D. C. 2000. Making tools for thinking, In Dan Sperber (ed.), Metarepresentations: A Multidisciplinary Perspective. Oxford University Press. 17-29.

Dennett, D. C. 2003. Freedom Evolves. New York, Viking. 
Dennett, D. C. 2011. Intentional Systems Theory. In B. McLaughlin, A. Beckermann és S. Walter (eds.) The Oxford Handbook of Philosophy of Mind, Oxford University Press.

Dennett, D. C. 2013. Intuition pumps and other tools for thinking, New York, W.W. Norton \& Company.

Descartes, R. 1642/2014 Elmélkedések az elsö filozófiáról, Budapest, Atlantisz Könyvkiadó

Descartes, R. 1994. A lélek szenvedélyei. Budapest, Ictus.

Diehl, M. 1990. The minimal group paradigm: theoretical explanations and empirical findings. In W. Stroebe \& M. Hewstone (eds.), European review of social psychology, Chichester, Wiley, 1, 263-292.

Dollard, J. 1935. Criteria for the Life History. New Haven, Yale University Press.

Donald, B. 2004. Human universals, human nature \& human culture, Daedalus, 133/4, 47-54

Donald, M. 1991. Origins of the Modern Mind. Cambridge, MA, Harvard University Press.

Doris, J. M. 1998. Persons, situations, and virtue ethics. Nous 32, 504-530.

Doris, J. M. 2002. Lack of Character: Personality and Moral Behavior. New York, Cambridge University Press.

Dúll, A 2009. A környezetpszichológia alapkérdései. Helyek, tárgyak, viselkedés. Budapest, L'Harmattan.

Dunbar, R. I. M. 2004. Gossip in an evolutionary perspective. Review of General Psychology, $8,100-110$.

Ehrenreich, B. 2006. Dancing in the streets. New York, Metropolitan.

Eisenberger, N. I., Lieberman, M. D., és Williams, K. D. 2003. Does rejection hurt? An fMRI study of social exclusion. Science, 302, 290-292.

Epstein, B., 2018. Social Ontology, In Edward N. Zalta (ed.) The Stanford Encyclopedia of Philosophy URL = <https://plato.stanford.edu/archives/sum2018/entries/social-ontology/>.

F. T. Cloak, Jr. 1975. Is a Cultural Ethology Possible? Human Ecology, 3/3, 161-182.

Fabry, R. E. 2017. Explaining enculturated cognition. In E. Davelaar, G. Gunzelmann, A. Howes és T. Tenbrink (eds.), Proceedings of the 39th Annual Conference of the Cognitive Science Society. Austin, Cognitive Science Society, 349-354.

Farkas, K. 2008. The Subject's Point of View. Oxford, Oxford University Press.

Festinger, L. 2000. A kognitív disszonancia elmélete, Budapest, Osiris Kiadó.

Fischhoff. B. 1975. Hindsight/foresight: The effect of outcome knowledge on judgment under uncertainty. Journal of Experimental Psychology: Human Perception and Performance, I, 288-299.

Fodor, J. 1980. Methodological Solipsism Considered as a Research Strategy in Cognitive Science, Behavioral and Brain Sciences, 3: 63-73.

Fodor, J. 1983. The modularity of mind. Cambridge, MA, MIT Press. 
Fodor, J. 2000. The mind doesn't work that way: The scope and limits of computational psychology. Cambridge, MA, MIT Press.

Foster, K. R. és Ratnieks, F. L. W. 2005. A new eusocial vertebrate? Trends in Ecology \& Evolution, 20, 363-364.

Freeman, N. H., és Habermann, G. M. 1996. Linguistic socialization: A Chinese perspective. In M. H. Bond (ed.), The handbook of Chinese psychology. Oxford, Oxford University Press, 79-92.

Freeman, W. J. 1995. Societies of brains. a study in the neurobiology of love and hate. Mahwah, NJ, Lawrence Erlbaum Associates.

Frege, G. 1892. On Sense and Reference. Reprinted in P. Geachand, M. Black [trans. és eds.], Translations from the Philosophical Writings of Gottlob Frege, Oxford, Blackwell, 1960.

Frege, G. 1918. The thought: A logical inquiry. (Reprinted in R. Harnish [szerk.], Basic Topics in the Philosophy of Language, Englewood Cliffs, NJ, Prentice Hall, 1994)

Freud, S. 1921. Group psychology and the analysis of the ego. In The Standard Edition of the Collected Works of Sigmund Freud, XVIII. London, The Hogarth Pres, 65-143.

Gallagher, S. 2009. Philosophical Antecedents of Situated Cognition, In Robbins P. és Aydede, M. (eds.) The Cambridge Handbook of Situated Cognition. New York. Cambridge University Press.

Gallagher, S. 2011. Introduction: A Diversity of Selves. In Gallagher, S. (ed.) The Oxford Handbook of the Self, Oxford University Press.

Gallagher, S. 2012. The overextended mind. Versus, 113, 57-68.

Gallagher, S. és Crisafi, A. 2009. Mental Institutions. Topoi. 28. 45-51.

Geertz, C. 1973. The interpretation of cultures: selected essays. New York, Basic Books

Georg, T. és Wilson, R. 2013. Group Mind - Draft entry for: Byron Kaldis (eds). Encyclopedia of Philosophy and the Social Sciences. Thousand Oaks, Sage.

Gertler, B. 2007. Overextending the Mind? In Gertler, B., Shapiro, L. (eds.) Arguing about the mind, Routledge.

Gigerenzer, G., Todd, P. M, és az ABC Research Group. 1999. Simple heuristics that make us smart. New York, Oxford University Press.

Giles, H. és Smith, P. M. 1979. Accommodation theory: Optimal levels of convergence. In H. Giles és R. St. Clair (Eds.), Language and social psychology. Oxford, Blackwell. 45-65

Giles, H., Coupland, N. és Coupland, J. 1991. Accommodation theory: communication, context, and consequence. In H. Giles, J. Coupland \& N. Coupland (eds.), The contexts of accommodation: developments in applied sociolinguistics Cambridge, Cambridge University Press, 1-68.

Gillihan, S. J., és Farah, M. J. 2005. Is Self Special? A Critical Review of Evidence from Experimental Psychology and Cognitive Neuroscience, Psychological Bulletin, 131, 76-97. 
Gislén, A. 2003. Superior Underwater Vision in a Human Population of Sea Gypsies. Current Biology. 13/10, 833-836.

Goldin-Meadow, S., Nusbaum, H. Kelly, S. és Wagner, S. 2001. Explaining math: Gesturing lightens the load. Psychological Science 12, 516-522.

Gray, J. 2003. How are qualia coupled to functions? Trends in Cognitive Sciences, 7/5,192194.

Gray, J. G. 1959. The warriors: reflections on men in battle. New York: Hartcourt, Brace and Company.

Gregory, R. L. és Wallace, J. G. 1963. Recovery from early blindness: A case study. Monogr. Suppl. no. 2, Q. Jl exp. Psychol. Cambridge, Heffers. (Reprinted in Gregory, R. L. 1974 Concepts and mechanisms of perception. London: Duckworth).

Halevy, N., Chou, E., és Galinsky, A. D. 2011. A functional model of hierarchy: Why, how, and when vertical differentiation enhances group performance. Organizational Psychology Review, 1, 32-52.

Hall, A. R. 1980. Philosophers at War: The Quarrel between Newton and Gottfried Leibniz. Cambridge University Press.

Harrison, A. A. és Fiedler, E. R. 2012, Behavioral Health. In Vakoch, D. A. (ed.) Psychology of space exploration: Contemporary research in historical perspective. Washington, DC, U.S. Government Printing Office.

Heath, S. B. 1982. What no bedtime story means: Narrative skills at home and school. Language in Society, 2, 49-79.

Heidegger, M. 1927/2007. Lét és idő, Budapest, Osiris.

Henrich, J. 2001. Cultural transmission and the diffusion of innovations: Adoption dynamics indicate that biased cultural transmission is the predominate force in behavioral change. American Anthropologist, 103, 992-1013.

Henrich, J., és Gil-White, F. 2001. The evolution of prestige: Freely conferred deference as a mechanism for enhancing the benefits of cultural transmission. Evolution and human behavior, 22/3, 165-196.

Henrich, J., Heine, S., és Norenzayan, A. 2010. The weirdest people in the world? Behavioral and Brain Sciences, 33/2-3, 61-83.

Henrich, J., McElreath, R., Barr, A., Ensimger, J., Barrett, C., Bolyanatz, A., 2006. Costly punishment across human societies. Science, 312, 1767-1770.

Hirt, E., Zillman, D., Erickson, G., és Kennedy, C. 1992. The costs and benefits of allegiance: Changes in fans' self-ascribed competencies after team victory versus team defeat. Journal of Personality and Social Psychology, 63, 724-738.

Hollan, J. és Stornetta, S. 1992. Beyond Being There. In P. Bauersfeld, J. Bennett, G. Lynch (eds.), ACM Conference on Human Factors and Computing Systems, Monterey, CA, ACM Press, 119-125. 
Hölldobler, B. és Wilson, E. O. 2009. The superorganism: The beauty, elegance and strangeness of insect societies. New York, W. W. Norton.

Hurley, S. 1998. Consciousness in Action, London, Harvard University Press.

Hurley, S. 2010. The Varieties of Externalism. In R. Menary (ed.) The Extended Mind, Cambridge, MA, MIT Press.

Hutchins, E. 1995. Cognition in the wild. Cambridge, MA, MIT Press.

Iwamura, Y. 1998. Hierarchical Somatosensory Processing. Current Opinion in Neurobiology, 8, 522-28.

James, W. 1884. What is an Emotion, Mind, 9/34, 188-205.

Ji, L. 2001. Culture, language and relationships vs. categories in cognition. Unpublished doctoral dissertation, Ann Arbor, University of Michigan.

Ji, L., Peng, K., és Nisbett, R. E. 2000. Culture, control, and perception of relationships in the environment. Journal of Personality and Social Psychology, 78, 943-955.

Johnston, J. 2002. A future for autonomous agents: Machinic Merkwelten and artificial evolution. Configurations, 10, $473-516$.

Jung N., Wranke C., Hamburger K., Knauff M. 2014. How emotions affect logical reasoning: evidence from experiments with mood-manipulated participants, spider phobics, and people with exam anxiety. Frontiers in Psychology, 5, 570.

Kahneman, D. 2011. Thinking, fast and slow. New York, NY, US, Farrar, Straus and Giroux.

Kahneman, D. és Tversky, A. 1982. Judgment under uncertainty: Heuristics and biases. In Kahneman, D., Slovic, P. és Tversky, A. (eds.), Judgment under uncertainty: Heuristics and biases. New York, Cambridge University Press, 3-23.

Kahneman, D., Fredrickson, B. L., Schreiber, C. A., Redelmeier, D. A. 1993. When More Pain Is Preferred to Less: Adding a Better End. Psychological Science, 4/6, 401-405.

Kesebir, S. 2012. The Superorganism Account of Human Sociality: How and When Human Groups Are Like Beehives. Personality and Social Psychology Review, 16/3, 233-261.

Kirsh, D. 1995. The intelligent use of space. Artificial Intelligence, 73, 31 - 68.

Kirsh, D. és Maglio, P. 1994. On distinguishing epistemic from pragmatic action. Cognitive Science, 18, $513-549$.

Krueger, T. 2007. Design and prosthetic perception, Kybernetes, 36/9-10, 1393-1405.

La Barre, W. 1954. The Human Animal. Chicago, University of Chicago Press.

Ladyman, J. és Ross, D. 2007. Every Thing Must Go: Metaphysics Naturalized. Oxford University Press.

Lakoff, G., és Johnson, M. 1999. Philosophy in the Flesh: The Embodied Mind and Its Challenge to Western Thought. New York, Basic Books. 
Le Bon, G. 1896/1920. The crowd: A study of the popular mind. London, Ernest Benn. A tömegek lélektana, Hermit Könyvkiadó, 2004.

Leary, M. R., Tambor, E. S., Terdal, S. J., és Downs, D. L. 1995. Self-esteem as an interpersonal monitor: the sociometer hypothesis. Journal of Personality and Social Psychology, 68, 518-530.

Lee, J. R. 1977. Rallying 'round the flag. Presidential Studies Quarterly, 7, 252- 256.

Leslie, A. M. 1994. ToMM, ToBy, and Agency: Core architecture and domain specificity. In

L. Hirschfeld and S. Gelman (Eds.), Mapping the mind: Domain specificity in cognition and culture, New York, Cambridge University Press, 119-148.

Levine, J. M. 1989. Reactions to opinion deviance in small groups. In P. B. Paulus (ed.), Psychology of group influence. Hillsdale, NJ, Erlbaum. 187-231.

Lieberman, M. D. és Eisenberger, N. I. 2009. Pains and pleasures of social life. Science, 323, 890-891.

Liszkowski, U., Carpenter, M., Henning, A., Striano, T. és Tomasello, M. 2004. Twelvemonth-olds point to share attention and interest. Developmental Science, 7, 297-307.

Lupyan, G. 2015. Cognitive Penetrability of Perception in the Age of Prediction. Predictive Systems are Penetrable Systems, Review of Philosophy and Psychology, 6.

Lupyan, G., és Ward, E. J., 2013. Language can boost otherwise unseen objects into visual awareness. Proceedings of the National Academy of Sciences 110/35, 14196-14201.

Mackenzie, A. 2004. We have always been . . cyborgs, Metascience, 13/2, 153-163.

Maguire, E. A., Gadian, D. G., Johnsrude, I. S., Good, C. D., Ashburner, J. Frackowiak, R. S. és Frith, C. D. 2000. Navigation-related structural change in the hippocampi of taxi drivers. Proceedings of the National Academy of Sciences, 97/8, 4398-4403.

Mann, S. 2001. Wearable computing: Toward humanistic intelligence, IEEE Intelligent Systems \& Their Applications, 16/3, 10-15.

Marshall, D. és Weatherson, B. 2018. Intrinsic vs. Extrinsic Properties", In Edward N. Zalta (ed.) The Stanford Encyclopedia of Philosophy, URL = <https://plato.stanford.edu/archives/spr2018/entries/intrinsic-extrinsic/>

Martin, A., és Chao, L. 2001. Semantic memory and the brain: Structure and processes. Current Opinion In Neurobiology, 11, 194-201.

Masuda, T., és Nisbett, R. E. 2001. Culture and attention to object vs. field. Unpublished manuscript, University of Michigan.

Maynard Smith, J. és Szathmáry, E., 1995. The Major Transitions in Evolution. Oxford, Oxford University Press.

McCauley, C. 2007. Psychological issues in understanding terrorism and the response to terrorism. In B. Bongar, L. M. Brown, L. E. Beutler, J. N. Breckenridge, és P. G. Zimbardo, (eds.), Psychology of terrorism, New York, Oxford University Press, 13-31. 
McCauley, R. és Henrich, J. 2006. Susceptibility to the Müller-Lyer illusion, theory-neutral observation, and the diachronic penetrability of the visual input system. Philosophical Psychology, 19/1, 1-23.

McDougall, W. 1920. Group mind: A sketch of the principles of collective psychology, with some attempt to apply them to the interpretation of national life and character. New York, G. P. Putnam's Sons.

McGurk, H. és MacDonald, J. 1976. Hearing lips and seeing voices. Nature, 264, 746- 748.

Menary, R. 2006. Attacking the bounds of cognition. Philosophical Psychology, 19, 329-344.

Menary, R. 2007. Cognitive Integration: Mind and Cognition Unbounded. Basingstoke, Palgrave Macmillan.

Menary, R. 2010a. Dimensions of mind. Phenomenology and the Cognitive Sciences, 9, 561578.

Menary, R. 2010b. Introduction: The Extended Mind in Focus, In R. Menary (ed.) The Extended Mind, Cambridge, Mass, MIT Press.

Menary, R. 2010c. Cognitive Integration and the Extended Mind, In R. Menary (ed.) The Extended Mind, Cambridge, Mass, MIT Press.

Merry, S. E. 1984. Rethinking gossip and scandal. In D. Black (ed.), Toward a general theory of social control, 1, New York, Academic Press, 271-302.

Metzinger, T. 2011. The No-Self Alternative. In Gallagher, S. (ed.) The Oxford Handbook of the Self, Oxford University Press.

Michaelian, K. és Sutton, J. 2013. Distributed Cognition and Memory Research: History and Current Directions. Review of Philosophy and Psychology, 4, 1-24.

Milgram, S. 1974. Obedience to authority: an experimental view. New York, Harper and Row.

Miller, J. G. 1984. Culture and the development of everyday social explanation. Journal of Personality and Social Psychology, 46, 961- 978.

Moè, A. és de Beni , R. 2005. Stressing the efficacy of the loci method: Oral presentation and the subject-generation of the loci pathway with expository passages. Applied Cognitive Psychology, 19, $95-106$.

Moore, C., és Dunham, P. J. 1995 (Eds.). Joint attention: Its origins and role in development. Hillsdale, Erlbaum.

Morgan, M. J. 1977. Molyneux's Question. Cambridge, Cambridge University Press

Nagel, S. K., Carl, C., Kringe, T., Märtin, R., és König, P. 2005. Beyond sensory substitution - learning the sixth sense. Journal of Neural Engineering, 2/4.

Nagel, T. 1974. What is it like to be a bat? Philosophical Review 83, 435-450. $\rightarrow$ magyar ford. 
Needham, A. és Baillargeon, R. 1993. Intuitions about support in 4.5-month-old infants. Cognition, 47, 121-148.

Newton, M. 2002. Savage girls and boys: a history of feral children. London: Faber and Faber.

Nisbett, R.E., Peng K., Choi, I., és Norenzayan A., 2001. Culture and Systems of Thought: Holistic Versus Analytic Cognition, Psychological Review, 108/2, 291-310.

Nolan, J. M., Schultz, P. W., Cialdini, R. B., Goldstein, N. J., és Griskevicius, V. 2008. Normative social influence is underdetected. Personality and Social Psychology Bulletin, 34, 913-923.

Norman, D. 1999. The Invisible Computer. Cambridge, MA, MIT Press.

Oliver, A. M. és Steinberg, P. F. 2006. The road to martyrs' square. a journey into the world of the suicide bomber. New York, Oxford University Press.

O'Regan, J. K. 1992. Solving the "real" mysteries of visual perception: The world as an outside memory. Canadian Journal of Psychology, 46, 461-488.

Pinker, S. 1997. How the Mind Works. New York, Norton.

Plaut, D. C. 1995. Double dissociation without modularity: Evidence from connectionist neuropsychology. Journal of Clinical and Experimental Neuropsychology, 17, 291-321.

Pléh, Cs. 1990. Wundt időszerüsége, Pszichológia, 2, 279-316.

Poeppel, D. 1996. A critical review of PET studies of phonological processing. Brain and Language, 55, 317-351.

Poirier, C., De Volder, A.G., Scheiber, C., 2007. What neuroimaging tells us about sensory substitution. Neuroscience and Biobehavioral Reviews. 31/7, 1064-1070.

Popper, K. 2009. Test és elme. Budapest, Typotex.

Popper, K. és Eccles, J. 1977. The Self and Its Brain. London, Springer-Verlag.

Prinz, J. J. 2006. Is the mind really modular? In Robert J. Stainton (ed.) Contemporary Debates in Cognitive Science. Blackwell, 22-36.

Prinz, J. J. 2006. The emotional basis of moral judgments. Philosophical Explorations, 9/1, 29-43.

Prinz, J. J. 2013. Beyond Human Nature, London, Penguin.

Pulvermüller, F. 1999. Words in the brain's language. Behavioral and Brain Sciences, 22, 253-336.

Putnam, H. 1975. The meaning of "meaning." In K. Gunderson (ed.), Language, Mind, and Knowledge. Minneapolis, University of Minnesota Press. Reprinted in H. Putnam, Mind, Language, and Reality: Philosophical Papers, New York, Cambridge University Press.

Quartz, S. R, és Sejnowski, T. J. 1997. The neural basis of cognitive development: A constructivist manifesto. Behavioural and Brain Sciences, 20, 537-596. 
Ramachandran V. S. és Blakeslee, S. 1998. Phantoms in the Brain: Probing the Mysteries of the Human Mind, New York, William Morrow.

Ramachandran, V. S., Rogers-Ramachandran, D., Cobb, S. 1995. Touching the phantom limb. Nature, 377, 489-90.

Redelmeier, D. A. és Kahneman, D. 1996. Patients' memories of painful medical treatments: real-time and retrospective evaluations of two minimally intrusive procedures, Pain, 66, 3-8.

Renier, L., Collignon, O., Poirier, C., Tranduy, D., Vanlierde, A. Bol, A., Veraart, C., De Volder, A.G., 2005. Cross-modal activation of visual cortex during depth perception using auditory substitution of vision, Neuroimage, 26/2, 573-580.

Rizzolatti, G. és Craighero, L., 2004. The mirror neuron system. Annual Review of Neuroscience, 27, 169-192.

Robbins, P. és Aydede, M. 2009 A Short Primer On Situated Cognition. In Robbins P. és Aydede, M. (eds.) The Cambridge Handbook of Situated Cognition. New York. Cambridge University Press.

Roediger, H. L. és McDermott, K. B. 1995. Creating false memories: Remembering words not presented in lists. Journal of Experimental Psychology. Learning, Memory, and Cognition, 4, $803-814$.

Roediger, H. L., Watson, J. M., McDermott, K. B. és Gallo, D. A. 2001. Factors that determine false recall: A multiple regression analysis. Psychonomic Bulletin and Review, 8, $385-407$.

Rogers, Y., Brignull, H. és Scaife, M. 2002. Designing dynamic interactive visualisations to support collaboration and cognition. In Proceedings of IEEE Sixth International Conference on Information Visualization, 4, Piscataway, NJ : IEEE Press, 39 - 50.

Rosenzweig M. R. és mtársai. 1972. Brain changes in response to experience. Scientific American, 226, $22-9$.

Ross, D. és Ladyman, J. 2010. The Alleged Coupling-Constitution Fallacy and the Mature Sciences, In R. Menary (ed.) The Extended Mind, Cambridge, Mass, MIT Press.

Ross, L. 1977. The intuitíve psychologist and his shortcomings. In L. Berkowitz (ed.), Advances in experimental social psychology, 10, New York, Academic Press, 173-220.

Ross, L. és Nisbett, R. E. 1991. The person and the situation: Perspectives of social psychology. New York, NY, England, Mcgraw-Hill Book Company.

Rowlands, M. 1999. The Body in Mind: Understanding Cognitive Processes. Cambridge, Cambridge University Press.

Rowlands, M. 2003. Externalism: Putting Mind and World Back Together Again. London, Acumen.

Rowlands, M. 2006. Body Language: Representation in Action. Cambridge, Mass.: MIT Press. 
Rowlands, M. 2010a. Consciousness, Broadly Construed, In R. Menary (ed.) The Extended Mind, Cambridge, Mass, MIT Press.

Rowlands, M. 2010b. The New Science of the Mind: From Extended Mind to Embodied Phenomenology, Massachusetts, MIT Press Cambridge

Rupert, R. 2004. Challenges to the hypothesis of extended cognition. Journal of Philosophy, $101,389-428$.

Ryle, G. 1949. The Concept of Mind, New York, Hutchinson \& Co.

Samuels, R. 1998. Evolutionary psychology and the massive modularity hypothesis. British Journal for the Philosophy of Science, 49, 575-602.

Scocchia, L., Valsecchi, M., \& Triesch, J. (2014). Top-down influences on ambiguous perception: the role of stable and transient states of the observer. Frontiers in human neuroscience, $8,979$.

Shapiro, L. 2004. The Mind Incarnate. Cambridge, Mass, MIT Press.

Shapiro, L. 2009. A review of Frederick Adams and Kenneth Aizawa, The Bounds of Cognition, Phenomenology and the Cognitive Sciences, 8, 267-273.

Sherif, M. és Sherif, C. W. 1965. Ingroup and intergroup relations. In James O. Whittaker (ed.) Introduction to Psychology. Philadelphia, Saunders

Sherif, M., Harvey, White, J., Hood, W. és Sherif C. 1954/1961. Intergroup conflict and cooperation: The Robbers Cave experiment. Norman, University of Oklahoma Book Exchange.

Shore, B. 1996. Culture in mind: Cognition, culture, and the problem of meaning. New York, NY, Oxford University Press.

Siegel, S. 2012. Cognitive penetrability and perceptual justification. Noûs, 46/2, 201-222.

Simon, B., Pantaleo, G. és Mummendey, A. 1995. Unique individual or interchangeable group member? Accentuation of intragroup differences versus similarities as an indicator of the individual versus the collective self. Journal of Personality and Social Psychology, 69, 106-119.

Simon, T. J. 1997. Reconceptualizing the origins of number knowledge: A nonnumerical account. Cognitive Development, 12, 349-372.

Simons, D. J. és Levin, D. T. 1997. Change blindness. Trends in Cognitive Sciences, 1, 261267.

Simons, D. J., és Chabris, C. F. 1999. Gorillas in Our Midst: Sustained Inattentional Blindness for Dynamic Events. Perception, 28/9, 1059-1074.

Slater, A., Morison, V., Somers, M., Mattock, A., Brown, E. és Taylor, D. 1990. Newborn and older infants' perception of partly occluded objects. Infant Behavior and Development, $13,33-49$.

Smith, E. R. és Henry, S. 1996. An in-group becomes part of the self: Response time 
evidence. Personality and Social Psychology Bulletin, 22, 635-642.

Sperber, D. 1996. Explaining Culture: A Naturalistic Approach. Oxford, Blackwell.

Spitz, R. A. 1945. Hospitalism: An inquiry into the genesis of psychiatric conditions in early childhood. The Psychoanalytic Study of the Child, 1, 53-74.

Sprevak, M. 2009. Extended Cognition and Functionalism. The Journal of Philosophy, 106, 503-527.

Stearns, S. C. 2007. Are we stalled part way through a major evolutionary transition from individual to group? Evolution, 61, 2275-2280.

Strack F., Martin L., Stepper S. 1988. Inhibiting and facilitating conditions of the human smile: a nonobtrusive test of the facial feedback hypothesis. Journal of Personality and Social Psychology, 54/5, 768-777.

Suchman, L. 1998. Human/machine reconsidered. Cognitive Studies, 5, 5 - 13.

Sutton, J. 2010. Exograms and Interdisciplinarity: History, the Extended Mind, and the Civilizing Process. In R. Menary (ed.) The Extended Mind, Cambridge, Mass, MIT Press.

Tajfel, H. 1981. Human groups and social categories. Cambridge: Cambridge University Press.

Tautz, J. 2008. The buzz about bees: Biology of a superorganism. Berlin, Springer-Verlag.

Thelen, E,, és Smith, L. B. 1994. A dynamic systems approach to the development of cognition and action. Cambridge, MA, MIT Press.

Tollefsen, D. P. 2006. From extended mind to collective mind. Cognitive Systems Research, 7/2-3, 140-150.

Tomasello, M. 2009. Why we cooperate. Boston, MA, MIT Press.

Tomasello, M., Carpenter, M., Call, J., Behne, T. és Moll, H. 2005. Understanding and sharing intentions: The origins of cultural cognition. Behavioral and Brain Sciences, 28, 675 691.

Tőzsér, J. 2008. Általános bevezetés: a test-lélek probléma, In Ambrus G., Demeter T., Forrai G., Tőzsér J. (eds.) 2008. Elmefilozófia szöveggyüjtemény, Budapest, L’Harmattan kiadó.

Triplet N. 1898. The Dynamogenic Factors In Pacemaking And Competition, American Journal of Psychology, 9, 507-533.

Turchin, P. 2006. War and peace and war. New York, Pi Press.

Turner, J. C., Hogg, M. A., Oakes, P. J., Reicher, S., és Wetherell, M. S. 1987. Re-discovering the social group: a self-categorization theory. Oxford, Basil Blackwell.

van Gelder, T. 1995. What might cognition be, if not computation? Journal of Philosophy, 91, 345-351.

von Frisch, K. 1967. The dance language and orientation of bees. Cambridge, MA, Harvard University Press. 
Vygotsky, L. S. 1978. Mind in society: The development of higher psychological processes. Cambridge, Mass, Harvard University Press.

Wegner, D. 2002. The Illusion of Conscious Will. Cambridge, Mass, MIT Press.

Wegner, D.M. 1986. Transactive Memory: a contemporary analysis of the group mind. In: Mullen B, Goethals G. R. (eds.) Theories of group behavior. New York, Springer-Verlag, 185-208.

Wegner, D.M. 1995. A Computer network model of human transactive memory, Social Cognition, 13, 319-339.

Weiskopf, D. 2008. Patrolling the mind's boundaries. Erkenntnis, 68, 265-276.

Wheeler, M. 2010. In defense of extended functionalism. In R. Menary (ed.) The Extended Mind, Cambridge, MA, MIT Press.

Wheeler, M. 2018. Martin Heidegger. The Stanford Encyclopedia of Philosophy, Edward N. Zalta (ed.), URL = <https://plato.stanford.edu/archives/win2018/entries/heidegger/>.

White, F. 1987. The Overview Effect - Space Exploration and Human Evolution, New York, Houghton-Mifflin.

Wilson, D. S. 1997. Incorporating group selection into the adaptationist program: a case study involving human decision making. In J. A. Simpson \& D. T. Kenrick (eds.), Evolutionary social psychology, Mahwah, NJ, Erlbaum, 345-386.

Wilson, D. S. és Wilson, E. O. 2007. Rethinking the theoretical foundation of sociobiology. The Quarterly Review of Biology, 82, 327-348.

Wilson, E. O. 1990. Success and dominance in ecosystems: The case of the social insects. Oldendorf/Luhe, Germany, Ecology Institute.

Wilson, R. 2004. Boundaries of the Mind: The Individual in the Fragile Sciences. New York, Cambridge University Press.

Wilson, R. A. és Foglia, L. 2016. Embodied Cognition, In Edward N. Zalta (ed.), The Stanford Encyclopedia of Philosophy, URL = <https://plato.stanford.edu/archives/spr2017/entries/embodied-cognition/>.

Wiltermuth, S. S. és Heath, C. 2009. Synchrony and cooperation. Psychological Science, 20, $1-5$.

Witkin, H. A., Lewis, H. B., Hertzman, M., Machover, K., Meissner, P. B. és Karp, S. A. 1954. Personality through perception. New York, Harper.

Wittgenstein, L. 1992. Filozófiai vizsgálódások. Budapest, Atlantisz.

Wundt, W. 1912/1916. Elements of folk psychology: Outlines of a psychological history of the development of mankind. London, Allen \& Unwin.

Yaden, D., Iwry, J., Slack, K., Eichstaedt, J., Zhao, Y., Vaillant, G., Newberg, A. 2016. The Overview Effect: Awe and Self-Transcendent Experience in Space Flight, Psychology of Consciousness: Theory, Research, and Practice, 3/1, 1-11. 
Yates, F. 1966. The Art of Memory. London, Routledge.

Zajonc, R B. 1965. Social Facilitation. Science. 149, 269-274.

Zajonc, R. B., Murphy, S. T. és Inglehart, M. 1989. Feeling and facial efference: Implications of the vascular theory of emotion. Psychological Review, 96/3, 395-416. 